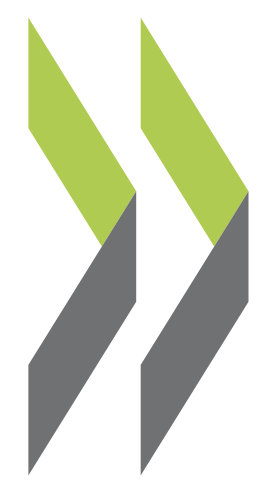

OECD Economics Department Working Papers No. 193

Dave Turner,

The Macroeconomic Implications of Ageing in a Global Context
Claude Giorno,

Alain de Serres,

Ann Vourc'h,

Pete Richardson 
THE MACROECONOMIC IMPLICATIONS OF AGEING

IN A GLOBAL CONTEXT

ECONOMICS DEPARTMENT WORKING PAPERS NO. 193

by

Dave Turner, Claude Giorno, Alain De Serres, Ann Vourc'h and Pete Richardson

Most Economics Department Working Papers beginning with No. 144 are now available through OECD's Internet Web site at http://www.oecd.org/eco/eco. 


\section{BSTRACT/RÉSUMÉ}

This study was prepared in the Economics Department as a contribution to the Organisation -wide study of the economic consequences of population ageing. It presents a number of long-term scenarios illustrating the likely domestic and international macroeconomic effects of ageing across the OECD and policies which might ameliorate or reverse underlying tensions. This work draws together the broad range of elements involved within a consistent framework, based on the Secretariat's new international dynamic general equilibrium macroeconomic model (MINILINK).

A "business-as-usual" case is examined in which, without improvements in labour market performance or specific policy adjustments to allow for the pressures of ageing, economic growth is projected to slow significantly over the next 50 years in nearly all OECD countries; world real interest rates remain stable at current levels or even rise, because of the effects of ageing on private savings and the possible build-up of public debt. Further analysis using model simulations, illustrate that a variety of domestic policies and reforms are likely to be beneficial although it is only through a combination of policies, carried out on a timely and co-ordinated international basis, that a potential slow-down in growth of living standards is likely to be avoided. A major uncertainty concerns prospective developments in the non-OECD area, and the role which OECD investments in these countries might play in improving OECD living standards. Preliminary analysis of this question suggests that without major structural reforms in the non-OECD, particularly in financial markets, such a contribution may be only modest.

$$
* * * * *
$$

Ce travail constitue une contribution du Département économique à l'étude réalisée au niveau de l'ensemble de l'Organisation sur les conséquences économiques du vieillissement des populations. Il présente un certain nombre de scénarios de long-terme illustrant d'une part les effets macroéconomiques probables du processus de viellisssement sur les plans national et international, sur les flux internationaux entre les régions OCDE et non OCDE et d'autre part le rôle des politiques économiques pour limiter ou éliminer les tensions générées par ce processus. Cette étude intègre dans un même cadre cohérent, basé sur le nouveau modèle international d'équilibre général dynamique du Secrétariat (MINILINK), un large ensemble d'éléments constitutifs du phénomène de vieillissement.

Le cas d'une scénario “à politique inchangé” est analysé. Il met en évidence qu'en l'absence d'amélioration des performances du marché du travail ou d'ajustement spécifique des politiques pour faire face aux tensions générées par le vieillissement, la croissance économique devrait ralentir sensiblement au cours des 50 prochaines années dans presque tous les pays de l'OCDE; les taux d'intérêt réels mondiaux devraient rester stables à leur niveau actuel ou même s'accroître en raison des effets du vieillissement sur l'épargne privé et de l'éventuel accroissement de la dette publique lié à l'augmentation des dépenses des administrations induites par le vieillissement. Par ailleurs, les analyses conduites à l'aide de simulations effectuées avec le modèle permettent d'illustrer les effets bénéfiques de toute une série de politiques économiques d'ordre intérieur, néanmoins, ce n'est seulement qu'avec un ensemble de politique économiques mises en oeuvres suffisamment tôt et coordonnées au niveau international que la baisse potentielle du rythme de croissance des niveaux de vie associée au processus de viellissement pourra être évitée. Une grande incertitude concerne les perspectives d'évolutions dans la zone non-OCDE et la contribution que les investissements des pays OCDE dans cette zone pourrait apporter à l'améliorartion des niveaux de vie des pays de l'OCDE. L'analyse préliminaire de cette question suggère que sans des réformes structurelles majeures, notamment une libéralisation des marchés financiers des pays non-membres, cette contribution ne pourrait être que modeste.

\section{Copyright: OECD, 1998}

Applications for permission to reproduce or translate all, or part of, this material should be made to: Head of Publications Service, OECD, 2 rue André-Pascal, 75775 PARIS CEDEX 16, France. 


\section{TABLE OF CONTENTS}

THE MACROECONOMIC IMPLICATIONS OF AGEING IN A GLOBAL CONTEXT ........................ 5

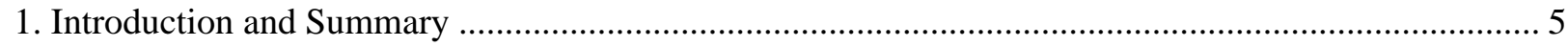

2. Assessing the effects of ageing in a long-term scenario context .................................................... 8

2.1. Key assumptions underlying the reference scenario ................................................................. 8

2.1.1. Demographic change and its implications for the OECD labour force ................................... 9

2.1.2. The direct effects of ageing on public finances ..................................................................... 11

2.1.3. The ex-ante effect of ageing on private savings behaviour .................................................. 12

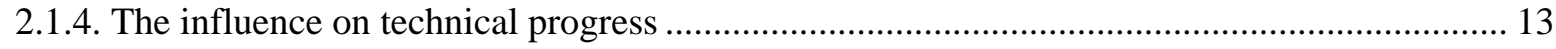

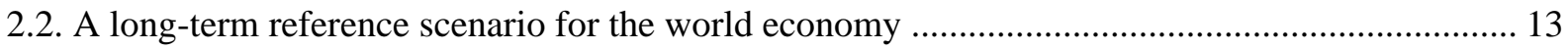

2.2.1. Effects on growth and the structure of the world economy …............................................. 13

2.2.2. Pressures on savings and investment and the response of interest and exchange rates .......... 14

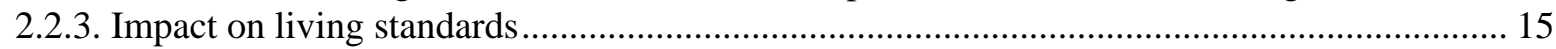

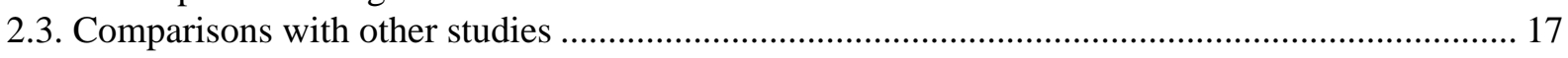

3. Policy responses to ageing and related macroeconomic influences ............................................... 19

3.1 Fiscal policy and the reform of welfare and pension systems ............................................... 19

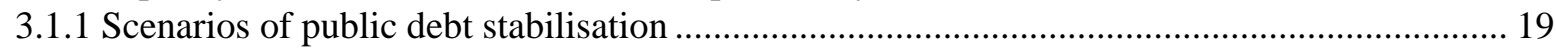

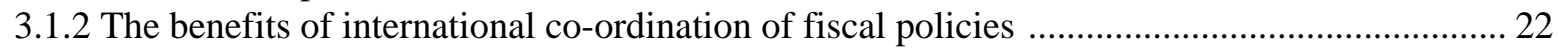

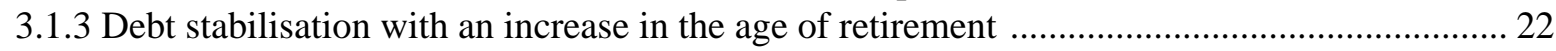

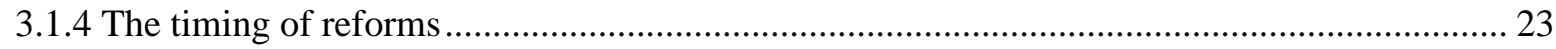

3.2 Market reforms, labour force participation and factor efficiency ……....................................... 24

3.2.1 The effects of higher labour force participation rates ............................................................ 24

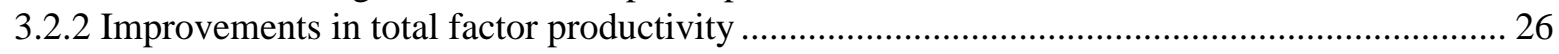

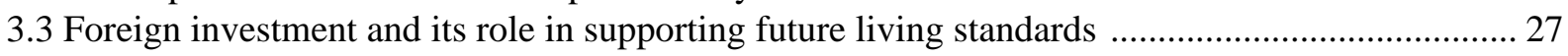

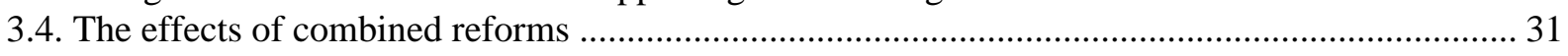

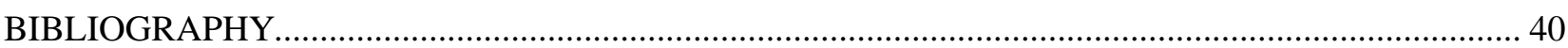




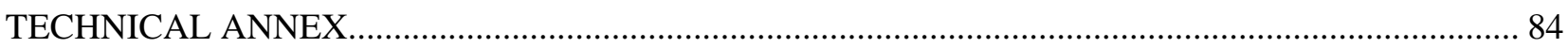

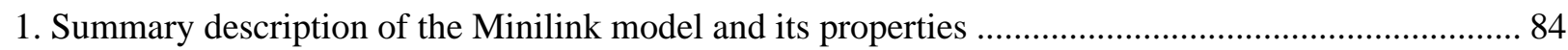

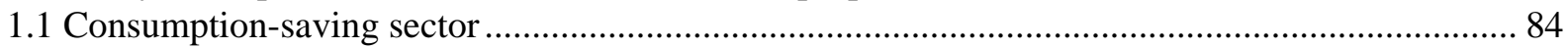

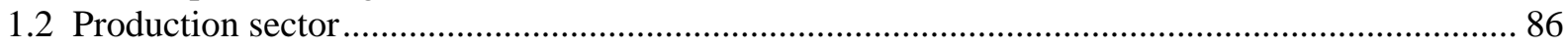

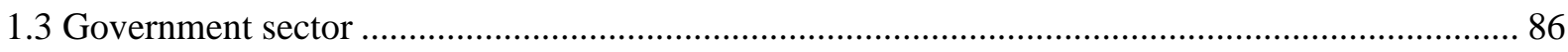

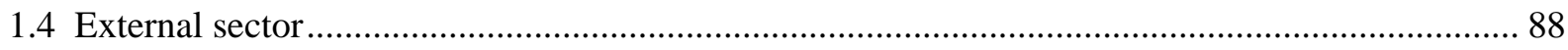

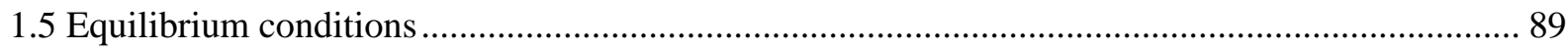

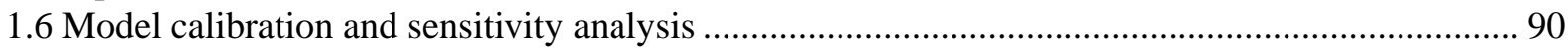

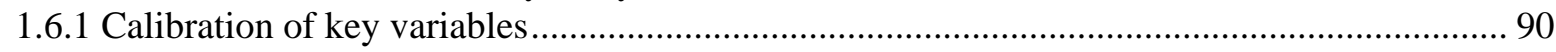

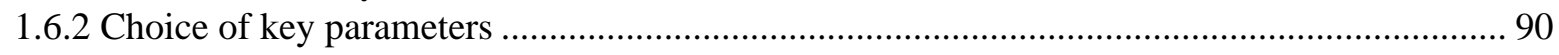

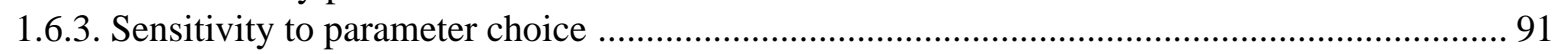

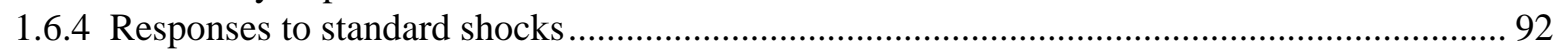

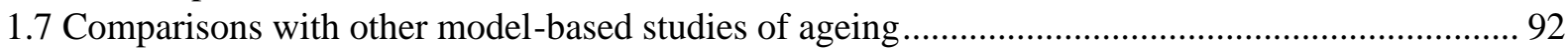

2. Demographic assumptions underlying the reference scenario .......................................................... 93

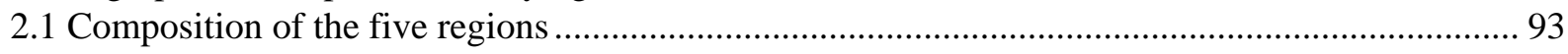

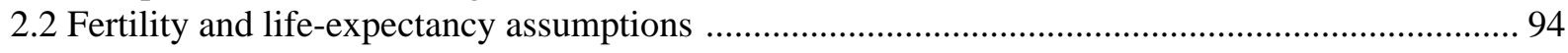

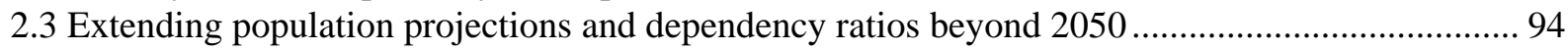

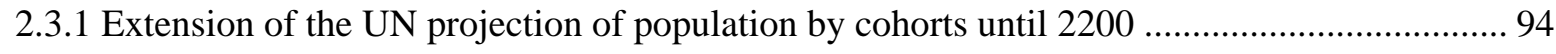

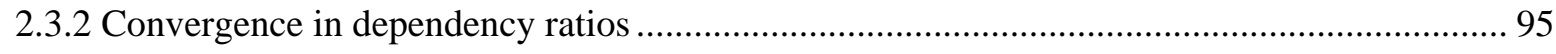

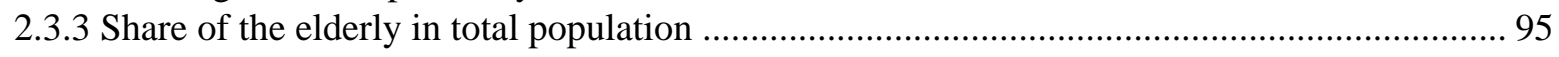

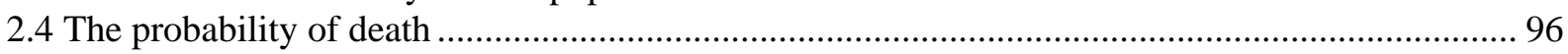

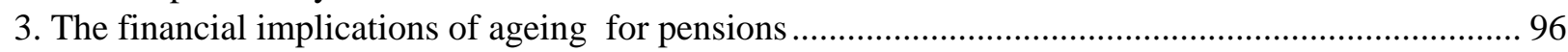

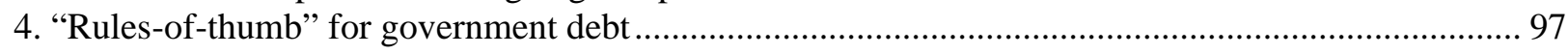

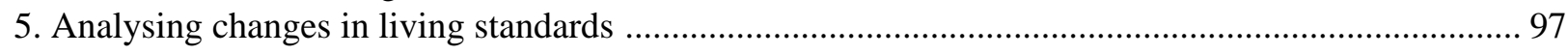

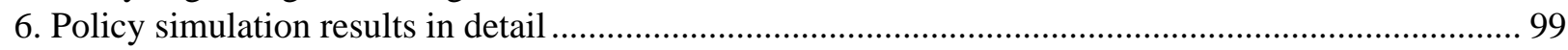




\title{
THE MACROECONOMIC IMPLICATIONS OF AGEING IN A GLOBAL CONTEXT
}

\author{
Dave Turner, Claude Giorno, Alain De Serres, Ann Vourc'h and Pete Richardson ${ }^{1}$
}

\section{Introduction and Summary}

1. Over the coming decades the populations of OECD countries will experience ageing, particularly as the post-war "baby boom" generation moves through the age structure, but also because people are living longer and fertility rates have fallen. While the same general pattern holds across most OECD countries, there are considerable differences in the speed with which such changes are likely to occur. This contrast is even more marked relative to non-OECD countries, which will typically experience ageing much later. Indeed, in many non-OECD countries dependency ratios are expected to fall over the next few decades ${ }^{2}$.

2. The ageing of populations will put pressures on government's tax and spending systems in nearly all OECD countries, requiring major changes to existing social systems if substantial increases in public debt are to be avoided. Private savings may also fall, to the extent that the elderly save less. The consequences of such effects are not limited to the domestic economy. Differential changes in national savings and investment balances will have important implications for international flows of goods and financial funds between countries and regions, which may also be reflected in major changes in exchange rates and balance of payments positions. Moreover, the magnitude of the changes which are likely to take place will have important implications for global savings and investment imbalances, and consequently for world interest rates. Ageing populations will thus have major effects on the growth of productive potential and living standards in all OECD and non-OECD countries.

1. This study was prepared in the Economics Department as a contribution to the Organisation-wide study of the economic consequences of population ageing. Ann Vourc'h is a member of the Resource Allocation Division; the other authors are all members of the Macroeconomic Analysis and Systems Management Division. Special thanks go to Frederick Guillemine and Marie-Christine Bonnefous for technical and programming support and Jan-Cathryn Davies and Veronica Humi for technical preparation. Thanks also go to numerous colleagues, including Martine Durand, Michael Feiner, Bob Ford, Peter Sturm and Ignazio Visco, for comments on a previous draft, and to Ralph Bryant of the Brookings Institution, Washington, D.C., for his advice on earlier versions of the Minilink model.

2. Throughout this paper the "dependency ratio" is defined to be the ratio of the population who are not of working age (both young and old) to those who are, where the population of working age is defined to be those between 15 and 64. The "old age dependency ratio" refers to the ratio of the number of elderly (aged 65 and over) to the population of working age. 
3. Many of these issues have been examined in the context of other studies and, in particular, the ongoing work of the OECD ${ }^{3}$. However, most of these have been concerned with partial analyses of the implications for single countries or individual aspects of the ageing problem, such as the implications for pensions, health care and public finances, private savings behaviour, labour markets or international capital flows. The present study differs in that it attempts to bring together the broad range of elements involved within a single consistent international macroeconomic framework; thus highlighting the difficulty of making longterm projections and analyses of the ageing problem without taking into account its global dimensions, the importance of international linkages and the equilibrating role of exchange rates and interest rates.

4. Against this background, this paper examines two broad macroeconomic issues:

- What are the likely domestic and international macroeconomic effects of varying degrees of ageing across OECD countries and what are the implications for international flows between OECD and non-OECD regions?

- To the extent that resulting trends or tensions appear to be unsustainable, how far can they be ameliorated or reversed by different policy responses?

5. To look at these questions, a number of long-term scenarios have been developed, illustrating the possible influence of ageing, associated demographic factors and alternative policies on the world economy. These are constructed within the broad framework of an international dynamic general equilibrium macroeconomic model of the world economy, Minilink (see Box 1 for a summary description), in conjunction with a range of estimates drawn from recent OECD empirical studies.

6. On the basis of available demographic projections, a reference scenario to 2050 is first elaborated, embodying the main influences of ageing on the world economy. Policies in this scenario are assumed to be set on a "business-as-usual" basis, with no special weight being given to the progressive influence of ageing on overall developments. As such it illustrates what might go wrong, given the nature of the cumulative tensions and domestic and international pressures which might build-up and, thereby, the areas requiring policy actions. Comparison of the reference case with several alternative scenarios provides a broad idea of the contribution of ageing to longer-term growth and living standards, and interactions between main OECD and non-OECD regions. A further series of alternative scenarios are then simulated using the Minilink model, illustrating the possible influence of alternative macroeconomic and structural policies, including different fiscal and labour market policy settings, on outcomes for key policy variables and, thereby, the scope for effective actions to offset any domestic and international tensions arising over the longer-term horizon (Table 1).

7. Without sustained improvements in factor productivity growth or changes in labour force participation rates, output growth in the OECD is likely to slow over coming decades. In the absence of specific policy adjustments, ageing populations will also tend to reduce the growth of living standards in the OECD as the output from any given number of workers is divided by a greater total population. Thus the direct mechanical effect of projected increases in the dependency ratio from current levels would lead to relative reductions in the levels of GDP per capita of around 10, 18 and 23 per cent for the United States, the European Union and Japan, respectively by $2050^{4}$.

3. See the studies cited in the extended bibliography and, in particular, OECD $(1996 a$ and $b)$ and the references therein. A summary of other modelling approaches is given in section 1.7 and Table A6 of the Technical Annex.

4. Other things being equal, living standards, as measured by the level of output per capita, are inversely related to (the sum of one plus) the dependency ratio, see the Technical Annex. 
8. Defining "living standards" in terms of GNP per capita, adjusted for terms of trade effects, a number of offsetting influences might be expected, particularly from capital deepening and from income earned on net external assets. The implicit slowdown in world growth might for example substantially reduce world interest rates, leading to greater capital intensity in production which, by raising labour productivity, would in turn boost living standards. The increased importance of the non-OECD in the world economy might also provide the opportunity for OECD countries to build-up net foreign assets and benefit from the associated future investment income flows, which along with improvements in the OECD terms of trade could also boost living standards.

9. However, such gains may not materialise if the ex ante propensity to save (public and private) declines. Without specific policy actions, reduced public saving and a considerable build-up in public debt may result from the pressures of ageing on pensions and health related expenditures and, although the evidence is mixed, life-cycle effects may also reduce private savings. If so, there may be little fall in world real interest rates from present ones and little prospect of capital deepening. Indeed the reverse could happen - contributing to a further decline in living standards. Similarly, a large decline in savings propensities might severely curtail any build-up in net foreign assets and any terms of trade improvement.

10. Within the OECD, such pressures are likely to be greatest and felt earliest by Japan, where the process of ageing is currently most advanced, but are likely to be experienced successively by the European Union and the United States over the next 50 years. The consequences of ageing are not confined to the OECD region. Indeed many of the largest and most productive non-OECD economies are undergoing similar transitions, whilst the growth prospects of others -- those with slower ageing populations -- depend crucially on trade with the rest of the world and conditions in world financial markets.

11. Reviewing the possible alternative developments in investment and, in particular, the contribution which increased foreign investment by OECD countries in the non-OECD might make to support living standards, the evidence presented suggests that such contributions are likely to be rather modest in relation to the scale of ageing effects on an OECD-wide basis, more so if such investments essentially involve a shifting away from domestic sources. Given a significantly more optimistic outlook for non-OECD growth than embodied in the reference scenario, there would be greater scope for OECD investment in those regions although, to reap such benefits, there would need to be major structural change in the product, labour and, particularly, capital markets of the non-OECD economies. Overall it seems likely that such an investment income contribution would be limited.

12. In these circumstances, a variety of largely domestic macro and structural policy actions within the OECD would seem to be called for. Clearly more needs to be done by governments to bring deficits under control and to stabilise debt, and to do so in the framework of reforming those areas most susceptible to the influence of the ageing process, namely pensions and health care ${ }^{5}$. In this context, lower expenditures (or generosity) as opposed to higher taxes (or contributions) would appear to be most acceptable, with the implicit increases in taxes required being potentially large and distortionary. At the same time, changes in the system of incentives related to retirement and measures to promote a later retirement age are likely to be particularly effective, since they reduce transfer payments and raise participation rates, as well as the levels of productive potential and the tax base. Policies promoting higher labour force participation and lower structural rates of unemployment are also important, though they are likely to have only transitory effects on growth in living standards. Probably of most importance are those regulatory and market reforms which promote higher efficiency and factor productivity growth, such as increased openness and competition, and macroeconomic

5. In the context of ageing populations, increased provision of public health care services may be desireable. Nevertheless, reforms may be required in many OECD countries to ensure that such services are delivered in the most cost effective way. 
stability, since the dynamic gains from these should have a permanent positive influence on growth in living standards.

13. Reviewing specific aspects of each of the above policies in the context of individual model simulations (summarised in Table 1), suggests that taken in isolation, none of the specified measures is likely to offset the projected decline in growth in OECD living standards. However, a suitable package of reforms comprising key elements of these policies should go a long way to re-establishing earlier growth trends, with favourable effects on world real interest rates and GNP. Specifically the benefits of such combined measures are estimated as raising growth in living standards by as much as $0.3,0.6$ and 0.7 per cent per annum for the United States, Japan and the European Union respectively and reducing real interest rates by up to $1 \frac{1}{2}$ percentage points, relative to the "business-as-usual" case.

14. Both timing and co-ordination are important. Delay in responding effectively to the fiscal issues is likely to lead to a larger build-up in debt and require potentially greater and less manageable changes in public finances in the longer term. At the same time, unilateral actions are likely to be less productive and run the risk of heightening international tensions, through large shifts in trade and payments situations and in real exchange rates.

15. The remainder of this paper is organised as follows. The long-term "reference scenario" is presented in section 2 along with its main assumptions and a discussion of key uncertainties. Section 3 then presents a range of alternative scenarios, illustrating the effects of alternative policy responses to underlying tensions, along with a review of the evidence from other studies. A Technical Annex describes the structure of the Minilink model, and its theoretical and empirical underpinnings, as well as giving details of standard simulation properties, sensitivity analysis to key assumptions and parameters and specific details of a number of "off-model" calculations involved in constructing the reference-case and alternative-policy scenarios.

\section{Assessing the effects of ageing in a long-term scenario context}

\subsection{Key assumptions underlying the reference scenario}

16. This section details the long-term reference scenario which embodies the main macroeconomic effects of ageing on the world economy. It is emphasised that this scenario is necessarily highly speculative and is not a forecast. It's main purpose is to provide a consistent framework for analysing the influences of ageing, the associated pressures and tensions which might build up and the possible policy responses to them.

17. The main channels through which the macroeconomic effects of ageing operate, and how they are incorporated in the present modelling framework are discussed below. These include: changes in the labour force; the effect on public finances from increased pressure on public health and pension expenditure; influences on private saving behaviour as a result of "life-cycle" effects; and possible effects on productivity. The long-term reference scenario is described in conjunction with a number of alternative scenarios, intended to clarify the contributions of the component ageing effects and to highlight particular areas of uncertainty.

18. Given the magnitude of the effects being considered, much of the macroeconomic adjustment to ageing must eventually come through changes in asset stocks, which are inevitably slow, and for this reason the time horizon of the analysis is much longer than the period of immediate interest. Thus, even though the ageing of OECD populations is expected to take place over the next 50 years, the projections cover a period which extends to the end of the next century. Inevitably, these become more speculative the further into the future they extend, so the main focus of the discussion is on developments to 2050. The scenario horizon considered begins at the start of the next century by which time it is assumed that the major OECD economies will be 


\section{ECO/WKP(98)6}

closer to macroeconomic equilibrium, defined in terms of output being close to potential, with stable external payments and fiscal positions.

19. The analysis distinguishes three main OECD regions -- the United States, Japan and the European Union -- and two mainly non-OECD regions, referred to as the "fast-ageing" and "slow-ageing" rest of the world regions? ${ }^{7}$. The criterion used to distinguish between the latter two regions is based on projected trends in dependency ratios, with those countries in which the ratio is expected to increase over the next 50 years included in the fast-ageing group (see the Technical Annex for further details). In terms of population, China accounts for more than 70 per cent of the fast-ageing rest of the world region, which also includes most Eastern European countries and most of the "other" OECD countries. The largest countries included in the "slow-ageing" rest of the world region are India, Indonesia, the Latin American countries, Mexico and Turkey.

\subsubsection{Demographic change and its implications for the OECD labour force}

20. The growth rate of world population, which is currently about $1 \frac{1}{2}$ per cent per annum, has fallen by more than $1 / 4$ per cent per annum since the early 1980 s and is likely to fall steadily over the coming decades to about $1 / 2$ per cent per annum by 2050 (United Nations, 1996). At the same time nearly all OECD countries and some non-OECD countries will experience a rise in the dependency ratio. In general, the slowdown in population growth and the rise in dependency ratios, which reflect underlying changes in fertility, longevity and migration, take place earlier in OECD countries than non-OECD countries, although there are marked differences even within the OECD area (Figure 1$)^{8}$.

21. These trends are most marked and occur the earliest in Japan, where the population is at present growing at 0.2 per cent per year and is expected to fall in absolute terms from 2010, and between 2020 and 2050 to decline at the rate of about 0.4 per cent per annum. The dependency ratio in Japan is expected to rise in two distinct phases; from 44 per cent currently to 65 per cent by 2020, stabilising at this level until about 2030, before rising again to 86 per cent by 2050 . The overall increase by 2050 is the largest in any of the regions identified in the current study.

22. Demographic trends for the European Union are similar to those for Japan, except that increases in the dependency ratio lag by some 10-15 years. Thus, the dependency ratio does not rise much above its current level of 49 per cent before 2010, but thereafter the projections imply a fairly sustained increase to 78 per cent by 2050. Population growth in the European Union is also expected to be negative after 2010, although again the decline is slower than for Japan.

23. The total population of the United States is currently growing relatively fast at just under 1 per cent per annum. This rate of growth is expected to slow only moderately by 2025 , down to $3 / 4$ per cent per annum, and then fall more sharply to 0.1 per cent per annum by $2050^{\circ}$. However, the population of working age, which

6. A scenario describing how the world economy might evolve towards such a position is described in the medium-term reference scenario reported in OECD Economic Outlook No. 62 (1997).

7. The situation of most other OECD countries, as regards ageing, can probably be located somewhere between that of the European Union, Japan and the United States.

8. The UN demographic projections assume no significant migratory movements beyond 2025. For countries with a long history of international migration, such flows are assumed to decline progressively over the period. For those where international migration is a more recent phenomenon, such flows are assumed to gradually taper off by 2005. The underlying demographic assumptions are described in more detail in the TechnicalAnnex.

9. The slowdown in the US population growth is partly due to the attenuation of immigration growth in the UN projections. 
is currently growing at 1 per cent per annum is expected to slow sooner and more markedly, with little growth beyond 2025. In the near term the dependency ratio is expected to fall slightly from a current level of 52 per cent to about 48 per cent by 2010 , and then to rise to around 65 per cent by 2030 , remaining stable thereafter.

24. The effects of ageing are least apparent in the slow-ageing rest of the world region. Total population in this region is currently growing at about 2 per cent per annum, with the population of working age growing even faster at $2 \frac{1}{2}$ per cent per annum. These rates of growth are likely to decline only slowly and are expected to still be about 0.7 and 0.5 per cent per annum, respectively by 2050 . The dependency ratio in this region falls more-or-less continuously to 2050 , from around 65 per cent at the start of the century to about 50 per cent by mid-century.

25. Population growth in the fast-ageing rest of the world region has already slowed considerably, from about $1 \frac{1 / 4}{4}$ per cent per annum ( 2 per cent per annum for the population of working age) in the mid-1980s to about 0.7 per cent per annum recently ( 0.9 per cent per annum for the population of working age). Population growth in this group of countries is expected to gradually fall to zero between now and 2050. The dependency ratio is expected to rise from 44 per cent currently to about 63 per cent by 2050 , although it is not expected to rise much above current levels until 2020 and the absolute increase in the ratio by 2050 is much less than for either Japan or the European Union.

26. Beyond 2050 (the limit of available United Nations projections) it is assumed that population growth rates and demographic structures converge across the different regions (see the Technical Annex for details of how these projections have been constructed). Thus, population growth rates are eventually assumed to stabilise a little below $1 / 2$ per cent per annum -- the United Nation's projection of the rate of growth of the world population by the year 2050. Dependency ratios are also assumed to converge. This means that beyond 2050 the dependency ratios for Japan and the European Union are assumed to fall, although the dependency rate at which all regions are assumed to converge, at 67 per cent, is substantially higher than at present for all three OECD regions.

27. The most direct macroeconomic impact of demographic changes is via effects on the labour force. Projections for labour force growth in the reference scenario are derived from those of the population of working age, assuming that age-specific labour force participation rates remain constant (Figure 2). Projections for the employed labour force are based on the assumption that unemployment rates are maintained at the NAIRU levels, which are assumed to remain stable at recent estimates of $23 / 4,51 / 2$ and $91 / 2$ per cent for Japan, the United States and the European Union respectively ${ }^{10}$.

28. Two different effects of population trends and demographic change can be distinguished. Firstly, a general slowdown in the growth rate of the total population (assuming an unchanged demographic structure) by lowering growth in the labour force, is likely to be reflected in a slowdown in output growth. Differences in population growth rates may thus be an important source of differences in countries growth performance and lead to changes in the relative size of economies over time, although, if dependency ratios remain broadly unchanged, there is no clear effect on living standards. Secondly, a rise in the dependency ratio, although it has only a temporary effect on the growth rate of the population of working age and hence output growth, is likely to permanently reduce living standards because the output produced by any given employed labour force has to be shared among a larger population.

10. Given its "business-as-usual" basis, the reference scenario assumes only modest progress in labour market policies. The implications of more active labour market policies and alternative developments in labour force participation are explored in the later part of the paper. In earlier work by the Secretariat [see Richardson (1997)], a "high-performance" scenario (based on significant policy actions) assumed that the NAIRU falls to around 5 per cent in the European Union. 


\section{ECO/WKP(98)6}

\subsubsection{The direct effects of ageing on public finances}

29. As outlined in the earlier work of Liebfritz et al. (1996) and Roseveare et al. (1996), three areas of public expenditure in the OECD regions are most likely to be strongly influenced by demographic developments, namely public provision of pensions, health care and, to a lesser extent education ${ }^{11}$.

30. In the absence of major reforms or increases in contribution rates to the largely unfunded OECD public pension systems, a substantial financing requirement will arise as the number of workers per pensioner falls. These pressures are likely to be greatest and felt earliest in Japan where the ratio of persons of working age to persons aged over 65 fall most steeply, from 4.7 currently to 1.8 in 2050 , although this ratio is also expected to fall over the same period from 4.3 to 2.0 in the European Union and from 5.2 to 2.8 in the United States. On the assumption of unchanged policies, the direct effect of public pension commitments (abstracting from interest payments on accumulated debt) would progressively increase government deficits over time. The largest effect, by far, would be for Japan where the pressure of pensions would lead to a progressive ex ante deterioration in government financial balances equivalent to 10 per cent of GDP by 2050 , Figure $3 a$.

31. Additional expenditures on public health care are also likely to take place, on the basis of health care for the elderly being on average more expensive than that for the non-elderly. For example, the ratio of expenditures on the elderly to the non-elderly is estimated for 1993 at 43/4, 41/4 and 3 for Japan, the United States and the European Union, respectively ${ }^{12}$. In constructing the scenario, it is further assumed that, abstracting from the age structure of the population, real per capita health costs rise in line with real wages costs (which is equivalent to the increase in productivity) and that there is otherwise constancy in the level of public health service provision (i.e. the ratio of expenditures on elderly to non-elderly is stable). On this basis, the direct effect of ageing on public expenditure on health (again excluding interest payments on any accumulated debt) could increase government deficits by the equivalent of nearly 2 per cent of GDP in the United States and about 3 per cent in Japan and the European Union by 2050 (Figure 3b.).

32. Allowance is also made for the potential effect of demographic changes on public spending on education in OECD countries. In 1993 direct public expenditures and subsidies for primary and secondary education as a percentage of GDP amounted to 3.8 per cent in the United States, 3.0 per cent in Japan and 3.6 per cent in Europe. Assuming that expenditures per child aged under 15 also grow in line with real wage costs, estimates of the impact of demographic changes on public education expenditure in the three main OECD regions can be calculated (Figure $3 c)^{13}$. The direct effect of future demographic developments on public education expenditure is, however, relatively modest compared to the effects on health and pensions ${ }^{14}$.

33. Left unchecked by policy adjustment, the deterioration in public sector finances associated with these separate contributions would lead to very substantial increases in budget deficits and, over the longer term, unsustainable levels of public debt. In constructing the long-term reference scenario, it was decided to apply a

11. For the two "rest of the world" regions, demographic pressures on public finances are ignored and these regions are assumed to target an unchanged debt-to-GDP ratio.

12. Disparities in relative health costs of the elderly and the non-elderly mainly reflect institutional differences between countries. For example, public cover of long-term health care is limited in Germany, whereas in the United States cover of under 65s is limited. See OECD (1996a), chapter 3.

13. Public education expenditures, which are initially expected to stabilise or fall relative to GDP in the three main OECD regions, would rise somewhat in a longer-term perceptive, reflecting prospective trends in "youth" dependency ratios.

14. These estimates do, however, confirm that ageing OECD populations will not lead to any savings on education expenditures, which might otherwise be used to offset the rising financial costs of health and pension provision. 
general "rule of thumb" which serves to limit the rise in debt as a per cent of GDP. Specifically it has been assumed that increases in net government debt as a per cent of GDP are limited to six times any increase in net flows of expenditure. For example, if overall expenditures rise permanently by the equivalent of 2 per cent of GDP, government debt is allowed to rise by no more than 12 per cent of GDP. Such a rule reflects the notion that in the past, OECD governments have responded to the pressures of increased expenditures by raising taxes, but with a lag, leading to a build-up of public debt ${ }^{15}$. Even if such a rule is applied to the above estimates of ex ante pressures on government finances from pensions, health care and education, public debt increases substantially to 2050 (Figure $3 d$ ): for the United States, it rises from just over 40 per cent to nearly 70 per cent; for Europe, from nearly 60 per cent to over 110 per cent; and for Japan, from nearly 25 per cent to over 100 per cent.

\subsubsection{The ex-ante effect of ageing on private savings behaviour}

34. If savings behaviour conforms to the traditional "life-cycle" hypothesis, by which households are assumed to save until retirement after which they dissave, then ageing populations are likely to lead to a lower private savings ratio ${ }^{16}$. However, empirical evidence in support of the life-cycle model, is very mixed. Meredith (1995), reviewing the empirical literature, shows that estimates of the sensitivity of the savings ratio to the dependency ratio vary considerably depending on whether they are based on microeconomic or macroeconomic, time series or cross-section data (Table 2).

35. On the basis of pooled-time series estimation across the major industrial countries, Masson and Tryon (1990), obtain an estimate suggesting that an increase of 1 percentage point in the dependency ratio causes a commensurate fall in the savings ratio. This would be consistent with a very high sensitivity of private savings to demographic changes, not very far removed from that typically found in calibrated overlapping-generations models [see, for example, Hviding et al. (1998)].

36. At the other extreme, household survey evidence typically suggests only a weak (or even positive) effect of the dependency ratio on private savings rates, see for example the studies summarised in Table 2. A recent empirical study using pooled time-series evidence for 21 industrial countries by Masson et al. (1995) provides further empirical support for a weak effect of dependency ratios on private savings rates (according to which a 1 percentage point rise in the dependency ratio reduces the private savings rate by 0.14 per cent).

37. The effect incorporated in the version of the Minilink model used to generate the long-term reference scenario, lies between these two extremes, but towards the lower end of these estimates, reflecting the weight of most recent evidence. It implies that a 1 percentage point rise in the dependency ratio reduces the private savings rate by 0.3 per cent ${ }^{17}$.

15. Regression estimates for the OECD area suggest that increases in primary expenditures by 1 per cent of GDP have typically, since the 1970s, been associated with increases in public debt of the order of 6 per cent of GDP (see Technical Annex for details).

16. The sign of the effect of ageing on saving depends on whether ageing comes about from lower fertility or greater longevity. Under the life-cycle hypothesis, a rise in life expectancy would leading individuals to save more during their working years in order to maintain consumption over a longer retirement period, and so generate higher aggregate private savings. By contrast, a decline in population growth due to lower fertility would leave individual savings profiles unchanged, but lead to lower aggregate savings as the proportion of the low-saving elderly in the population increased [Sturm (1983)].

17. In the model this effect operates through a "probability of death" parameter which has a direct effect on the propensity to consume out of wealth. This parameter is assumed to vary directly with mortality rates derived from UN projections. Given a rough rule of thumb that every 1 point change in the old age dependency ratio is 


\section{ECO/WKP(98)6}

\subsubsection{The influence on technical progress}

38. Ageing may also have a direct impact on productivity trends, although to date the empirical evidence for such an effect is not robust and even the direction of any effect remains uncertain ${ }^{18}$. For this reason no specific effect on productivity is assumed, although the assumptions regarding future trends in technical progress are inevitably critical to the long-term macroeconomic projection.

39. In the reference scenario, the growth rates of labour efficiency are initially assumed to be consistent with recent historical experience in each of the respective regions. It is assumed that growth in (labouraugmenting) technical progress in all regions eventually converges to around $1 \frac{1}{2}$ per cent per annum -- a figure consistent with the average figure for the OECD in the long-term scenarios detailed in Richardson (1997) ${ }^{19}$. Convergence is assumed to be gradual, with technical progress in the two largely non-OECD regions slowing only gradually to this rate by 2080 . Given that growth in labour efficiency in these regions is initially much higher ( 2 and 23/4 per cent per annum in the fast-ageing and slow-ageing regions, respectively) this implies that during the period of catch-up the non-OECD regions are gaining in size relative to the OECD regions.

\subsection{A long-term reference scenario for the world economy}

40. Key features of the long-term reference scenario are illustrated in Figures 3 to 10 and Tables 3 to 6, and described in the following sections, with particular emphasis on developments in the OECD region to 2050.

\subsubsection{Effects on growth and the structure of the world economy}

41. A key feature of the reference scenario is that the projected slowdown in the growth rate of the working-age population and, thereby, a shrinking labour force contributes to a general decline in potential economic growth rates in all regions (Table 3 and Figure 4$)^{20}$. Part of the slowdown in growth in the nonOECD regions, and to a lesser extent in the European Union, occurs also because of a slowdown in technical progress as levels of productivity converge.

42. The effect on Japan is most striking, with GDP growth falling below 1 per cent per annum before 2010 and falling further to only $1 / 4$ per cent per annum by 2040. The growth rate of the European Union falls more gradually, but is less than 1 per cent per annum by 2020, and averages less than $1 / 2$ per cent per annum between 2030 and 2040. The effect on US GDP growth is less pronounced, declining only gradually from present levels to reach a low of $1 \frac{1 / 4}{4}$ per cent by about 2030 .

associated with a rise in mortality rates of 0.03 , it is possible to calculate the effect on the savings rate referred to in the text. The detail underlying this calculation is presented in the Technical Annex.

18. A more aged workforce can either be less dynamic and innovative and hence have a negative impact on productivity growth, or alternatively relative labour scarcity may act as a stimulus to technical progress and boost productivity growth.

19. This growth rate of technical progress was based on the assumption of unchanged policies in the OECD and nonOECD. The implications of alternative, more favourable productivity trends are considered in the later part of this paper.

20. The present analysis assumes the labour supply to be the main limiting factor on production and therefore abstracts from the possible influences of other factors such as limited natural resources (water, energy, etc.) and/or limitations due to environmental causes (carbon emissions, etc.). These latter aspects though potentially important, are not strictly relevant to the analysis of the effects of ageing. 
43. Although growth rates for all regions are expected to fall, the weight of the non-OECD regions is likely to increase substantially in the coming decades because growth in these regions is falling from much higher rates. Ageing populations will thus contribute to major changes in the relative sizes of countries in the world economy. The combined weight of the three main OECD regions, using 1995 purchasing power parities, falls from about 46 per cent of world GDP at the turn of the century to less than 30 per cent by 2050 (Figure 5). The main counterpart of this fall is a rise in the share of the slow-ageing rest of the world region, with the share of the fast-ageing region little changed.

\subsubsection{Pressures on savings and investment and the response of interest and exchange rates}

44. Overall, movements in interest rates, exchange rates and international capital flows in the reference scenario reflect various conflicting pressures on savings and investment. Broadly speaking, to the extent that imbalances in savings and investment occur at the global level they are likely to be reflected in movements in real interest rates, whereas to the extent that they occur in particular regions they will be reflected in changes in exchange rates and net foreign asset positions ${ }^{21}$. The main pressures on savings and investment can be distinguished as follows:

i) the world-wide slowdown in output growth, reducing the required growth in the capital stock and so the proportion of output which needs to be devoted to investment;

ii) the decline in the weight of the OECD in world output, tending to initially improve OECD current account balances, i.e. raise OECD savings relative to investment, as non-OECD import demands grow faster than OECD import demands;

iii) the negative impact of demographic changes on private and public savings, initially concentrated in the OECD where population ageing occurs most rapidly.

45. The effects of these pressures -- each taken in isolation -- on interest rates, exchange rates and net foreign asset positions are summarised in Table $4^{22}$.

46. From the perspective of the world economy, there is likely to be an ex ante reduction in both investment and savings [effects (i) and (iii) above], and the question as to which is likely to fall the most, must ultimately be empirical. In the reference scenario, downwards pressures on savings slightly exceed those on investment, as reflected in a gradual rise in world interest rates which rise by up to $1 / 2$ percentage point by $2050^{23}$.

47. To further clarify the forces acting in the reference scenario, the latter can be compared with an alternative "higher-savings" scenario in which the (largely negative) demographic effects on savings [effect (iii) above] are excluded ${ }^{24}$. Thus, the higher savings scenario assumes there is no demographic effect on private savings behaviour - which may be more consistent with household survey evidence (see section 2.1.3 above). It

21. Regional imbalances need not lead to global imbalances if the weight of the region in the world economy is small and/or if there are offsetting imbalances in other regions.

22. The separate factors underlying these response are analysed in more detail in Box 2, using a simplified tworegion (OECD and non-OECD) version of the model.

23. World real interest rates are measured as a weighted average of real interest rates (net of any sovereign risk premium) in each region, with weights determined by the size of a regions contribution to world output.

24. Given the uncertainties about the demographic effects on savings, these results may also be of interest in their own right as an "optimistic" reference case, as well as providing a benchmark. 


\section{ECO/WKP(98)6}

also assumes that any demographic pressures on government spending are completely offset by equivalent cuts so that there is no rise in government debt as a share of GDP - which may be more consistent with recent emphasis given to fiscal restraint in many OECD countries ${ }^{25}$. In the higher-savings scenario, world real interest rates fall steadily, and are as much as $2 \frac{1}{2} 2$ percentage points lower than in the reference scenario by 2050 (Figures 6 and 7). Consistent with the faster growth of the non-OECD compared to the OECD, and hence the greater returns to capital, interest rates in the OECD (even after adjusting for sovereign risk premia) would be lower than in the non-OECD in both scenarios.

48. In the reference case, as well as in the higher savings scenario, the declining weight of the OECD in world output would initially generate OECD current account surpluses [effect (ii) above] although this tendency is increasingly offset by an appreciation of OECD exchange rates. Moreover, in the reference scenario the balance between savings and investment pressures, shifts more quickly and decisively in the direction of insufficient (national) savings in the case of the OECD, [effect (iii) above] (Figure 8). Thus, initial OECD current account surpluses eventually become deficits and the build-up in OECD net foreign assets is reversed.

49. Another way of looking at this is that all three main OECD regions experience a prolonged period of current account surplus of about 2 to 3 per cent of GDP, to 2025, 2030 and 2040 for Japan, the United States and European Union respectively, and a consequent build-up in net external assets (Figure 9). Beyond these dates the progressive effect which ageing has in reducing savings is dominant and the main OECD regions move into sustained current account deficit.

50. Japan is the earliest country to move into current account deficit, although it still maintains positive net foreign assets until almost 2050 as a consequence of starting from a strong initial position. The United States experiences a deterioration in the current account slightly later, but starting with a less favourable initial position moves into a net external debt position somewhat earlier. The European Union is the only OECD region with substantial net external assets by 2050 . However, beyond this point the net external asset position of the main OECD regions deteriorates further, with all becoming major net debtors by 2070.

51. These results may be contrasted with those of the "higher-savings scenario" where the main OECD regions, move into current account deficit later. In particular, Japan maintains current account surpluses until almost 2050 (rather than 2025). The net external asset positions of the main OECD regions are thus considerably strengthened, with only the United States becoming a significant net debtor beyond 2050 (Figure 9).

52. The magnitude of the swings in net foreign asset positions in both the reference and higher savings scenarios is considerably larger than has recently been experienced. This partly reflects the assumption of nearperfect capital mobility which underlies the model projections ${ }^{26}$. Nevertheless, there are a number of factors suggesting that the past may not be a reliable guide to future developments (see Box 3 ) and that future changes in net foreign assets might, indeed, be larger than previously experienced.

\subsubsection{Impact on living standards}

53. The issue which is perhaps of most concern to policy makers is the effect which ageing may ultimately have on per capita living standards. The long-term reference scenario suggests that living standards will continue to rise in the main OECD regions, despite ageing. Thus, for example, living standards, expressed

25. More specific analyses of the implications of alternative fiscal policy assumptions are given in Part 3 of this paper.

26. Capital in the OECD region is not a perfect substitute for capital in the mainly non-OECD region, given the presence of substantial sovereign risk premia in the latter. 
in terms of GNP per capita adjusted for terms-of-trade changes, could be about 80,90 and 100 per cent higher by 2050 in the United States, Japan and the European Union respectively than at the turn of the century ${ }^{27}$. Nonetheless, implied rates of growth in living standards are markedly slower than in previous decades, especially in Japan and the European Union (Table 5). Thus, for Japan it slows from over 11/4 per cent per annum in the first decade to below 1 per cent per annum in 2040-50; for the European Union from just under 2 per cent per annum to just over 1 per cent per annum in 2040-50; and for the United States from over 1/1/4 per cent per annum in the first decade to less than 1 per cent per annum by 2010-2030, before recovering to a rate slightly above 1 per cent per annum in 2030-2050.

54. The factors underlying this relatively poor performance are analysed in Figure 10 using an extension of growth accounting in which growth in living standards is decomposed into six contributory factors as follows (see Technical Annex for details):

- growth in labour efficiency (positive) ${ }^{28}$;

- changes in dependency ratios (negative);

- changes in capital intensity of production (positive);

- changes in investment income from abroad (positive);

- changes in participation rates (positive);

- changes in terms of trade (positive).

55. A feature common to all three regions is that the largest positive contribution to growth in living standards is associated with labour efficiency growth (Figure 10): for Japan this contribution raises living standards by just under $1 \frac{1}{2}$ per cent per annum throughout the projection period; for the United States it rises from $1 \frac{1}{4}$ per cent per annum in the first decade to $1 \frac{1 / 2}{2}$ per cent from 2020 onwards; and for the European Union it falls from just under 2 per cent per annum in the first decade to just under $1 \frac{1 / 2}{2}$ per cent per annum from 2020 onwards.

56. The largest negative contribution to growth rate in living standards in all three OECD regions is consistently associated with the rise in the dependency ratio, as the output produced by the employed labour force is progressively shared amongst larger populations. For Japan growth in living standards is reduced by a little over $1 / 2$ per cent per annum in the period to 2020 and by $3 / 4$ per cent per annum in the decade to 2040 . The negative contribution is smaller over the intervening decade, reflecting the temporary slowdown in the rise of the dependency ratio in 2020-30. For the European Union, there is little or no effect before 2010, but thereafter growth in living standards is damped by about $1 / 2$ per cent per annum between 2020 and 2040 due to this factor. For the United States there is a small positive contribution of $1 / 4$ per cent per annum to growth in living standards in the decade to 2010, but between 2020 and 2040 there is larger negative contribution of about $1 / 2$ per cent per annum. By 2050, the direct cumulative effects of the rise in dependency ratios is to reduce per capita living standards by about 10, 18 and 23 per cent for the United States, the European Union and Japan, respectively, relative to a situation where (other things being equal) dependency ratios remain at current levels.

27. The measure of "living standards" used here is GNP per capita expressed in terms of domestic absorption rather than production prices. Thus for a country with an appreciating exchange rate, imports become increasingly cheap relative to domestically-produced goods, so boosting the consumption possibilities of any given level of GNP per capita.

28. The terms in brackets refer to the partial derivatives with respect to increases in each of these factors. 


\section{ECO/WKP(98)6}

57. In addition to the effect of the dependency ratio, demographic effects are likely to have an effect on the size of the labour force, by altering the age structure of the population of working age. Such effects appear significant in the projections for both the European Union and Japan, although the directions are different. In Japan, there is a positive effect on the growth of the labour force up to 2020 as a greater proportion of the population of working age is concentrated in the age groups with the highest participation rates. This effect offsets, albeit only partially, some of the negative impact of a higher dependency ratio, raising the growth rate of living standards by $1 / 4$ per cent per annum in the period to 2020. Conversely in the European Union this effect tends to re-enforce the negative impact of a rising dependency ratio, reducing growth of living standards by a further 0.1 to 0.2 per cent per annum up to 2030 .

58. An increase in the capital intensity of production, by raising labour productivity, may also contribute to living standards. Indeed, in a situation where ageing populations lead to relative scarcity in labour a switch to more capital intensive production might be expected. Such effects are, however, virtually absent from the long-term reference scenario described here: the contribution of changes in capital intensity to the growth in living standards are mostly small and negative for the three OECD regions. This result reflects the downwards pressures which ageing populations place on both private and public savings and the consequent crowding out of the capital stock by higher interest rates. Conversely, in the "higher-savings" scenario, in which such pressures on savings are excluded, lower interest rates lead to a much greater increase in capital-intensity. This in turn raises living standards for all the OECD regions by between $81 / 2$ and $11 \frac{1}{2}$ per cent by 2050 (or the equivalent of just under $1 / 4$ per cent per annum to the growth rate of living standards over the period to 2050), with the gains being largest for Japan and Europe (Table 6).

59. Net investment income earned on external assets also makes a small positive contribution to growth in living standards while the stock of net external assets is still being built up, that is until about 2025 for Japan and the United States and about 2035 for the European Union. Beyond this point the progressive rundown in net external assets acts as a drag on growth of living standards. One reason why there is not a larger build-up in OECD net foreign assets, and hence a larger contribution to the growth in living standards, is the downwards pressure on OECD savings. In the "higher-savings" scenario, where such effects are excluded, there is a larger build-up in OECD net foreign assets and the positive contribution to growth in living standards is both higher and more prolonged. Nevertheless, because the benefits of holding higher external assets are partly offset by the influence of lower world interest rates, this makes a relatively modest contribution raising the levels of living standards by $1 \frac{1}{2}, 2 \frac{1}{2}$ and 5 per cent for the United States, the European Union and Japan respectively by $2050^{29}$.

\subsection{Comparisons with other studies}

60. Comparisons with other studies of the macroeconomic effects of ageing are difficult, because very few have been done within a general-equilibrium, multi-country framework. Most other studies have been concerned with a partial analysis, for example considering only the effects on savings behaviour [see, for example, OECD (1996a)] or only considering the implications for a single economy [see, for example, Yashiro and Oshio (1997) $]^{30}$. Examining the macroeconomic consequences of ageing populations for a single economy is problematic because nearly all of the major economies will be experiencing major demographic change in coming decades. The process of adjustment for any single economy -- in particular whether it takes place

29. The gains to the standard of living from investment income for the OECD may be understated because investment income is calculated on the basis of net, rather than gross, foreign asset stocks. If rates of return in the non-OECD are higher, then substantial OECD net investment income might be possible even if the OECD's net foreign asset position is weak or negative.

30. Section 1.7 and Table A.6 of the Technical Annex provide a comparison of the various approaches taken by other major empirical studies of the macroeconomic effects of ageing. 
through changes in net foreign assets and exchange rates or through interest rates -- depends on the extent and speed with which ageing is taking place relative to the rest of the world.

61. In OECD (1996a), projections of OECD savings rates are made combining estimates of the effect of future dependency rates on private savings with an assessment of the effect of ageing pressures on public savings (with alternative assumptions about the degree of Ricardian equivalence -- i.e. the extent to which a change in public savings is offset by a change in private savings). The resulting projections, showing OECD net national savings falling from about 7 to 8 per cent of GDP currently to between zero and minus 8 per cent of GDP in 2030, appear improbable once considered alongside possible rates of national investment ${ }^{31}$. Such results again highlight the problem of making long-term projections in a partial framework without taking into account the equilibrating role of exchange rates and interest rates ${ }^{32}$.

62. Borsch-Supan (1996) uses the Cass-Ramsey-Solow optimal growth model, as popularised by Cutler et al. (1990), to carry out a general equilibrium analysis of the effects of ageing populations on OECD savings and investment. Such a model is useful to predict changes in the optimal savings rate over time, with the aggregate savings rate responding to relative scarcity of labour and capital. However, it does not allow for the possible pressures on savings from life-cycle effects or from the effect which ageing might place on public finances. It does, however, demonstrate that in the absence of such effects (a situation which corresponds with the "higher-savings" scenario considered earlier), substantial falls in interest rates (of up to 3 percentage points by 2025) might be expected.

63. The study which can most readily be compared with the present one is that of Masson and Tryon (1991), who use the IMF's macroeconomic model of the world economy, MULTIMOD, to assess the macroeconomic effects of ageing. However, even this study abstracts from the effects of a continued slowdown of population growth and instead focuses just on the effects of the change in the age structure of the population $^{33}$. The main conclusions of the study concerning the effects of ageing on the world economy are that:

- the main cost to the world economy of ageing comes through the lost production as a result of a lower labour force: real GNP in 2025 is reduced by 13 per cent in Japan and 6 per cent in Germany, although there is a much smaller effect on the United States with aggregate output being increased for much of the early part of the next century;

- beyond 2015, as the populations in nearly all industrial countries are ageing, interest rates rise progressively, by between 3 percentage points (for the United States) and 5 percentage points (for Japan $)^{34}$;

31. Large negative national savings rates for all OECD countries would either require negative net investment, and by implication, negative output growth or imply large sustained current account deficits with the non-OECD.

32. If excess ex ante pressures on OECD savings were as large as implied by these projections then there would be downwards pressures on OECD exchange rates and possible upwards pressures on world interest rates, which would tend to bring OECD savings and investment back into balance.

33. The study compares a simulation with a baseline, in which the total population is assumed to be the same in both, but the age structure is different. The focus of the analysis is then the differences between the simulation and baseline, and, unlike the present study, it does not attempt to provide any long-term projection of the world economy in absolute terms.

34. This study does not, however, attempt to assess how far this would be offset by the downward pressures on interest rates which might occur because of the corresponding slowdown in world population growth. 
- population ageing has the potential to generate large swings in foreign indebtedness over time: in Japan and Germany net foreign asset positions in 2025 are reduced by about 60 and 25 per cent of GDP, respectively, whereas that of the United States improves by 35 per cent of GDP;

- government financial positions weaken, as tax revenues fall and pension expenditures increase substantially in all industrial countries. In particular, government debt in Germany and Japan rise by 19 and 27 per cent of GDP by 2025 .

\section{Policy responses to ageing and related macroeconomic influences}

64. As illustrated by the reference scenario, the effects of ageing are likely to significantly reduce growth in OECD living standards relative to the average of the past four decades (Table 5). Faced with such a possibility, a number of different policy responses can be envisaged. With the aid of a number of alternative policy scenarios and evidence from relevant empirical studies, this section attempts to gauge the potential macroeconomic impact of policy responses in primarily three areas: fiscal policies and the reform of welfare and pension systems, labour market reforms, and reforms to improve factor efficiency. It also provides an assessment of the potential role of increased foreign investment by OECD countries to offset the effects of ageing on living standards.

\subsection{Fiscal policy and the reform of welfare and pension systems}

65. As indicated in the previous section, the ageing process will put public finances in most Member countries under severe strain in the coming decades. Accompanied by a possible fall in private saving, total national saving in most OECD countries would also decline, putting upward pressure on real interest rates which in turn would lead to a slowdown in capital accumulation and growth, and ultimately slower growth in overall living standards. In such a context, it would seem prudent to introduce policies designed to raise national saving ratios in the years immediately ahead. The most direct way to achieve this would be to reduce public dissaving. In fact most OECD countries have already embarked on or are considering reforms of their public and health pension schemes, and the social security reforms envisaged in response to ageing pressures cover a fairly wide range of options. The consequences of these different types of reforms, as discussed in OECD (1996a), vary considerably in terms of microeconomic effects and intergenerational equity.

66. On the macroeconomic level, however, the range of possible strategies for public finances seems fairly limited. In the following sections, a number of scenarios are developed which identify the potential impact of different options for fiscal policy and reform of pension and social security systems on macroeconomic performance. The purpose of these scenarios is not to provide a realistic description of what fiscal policies might be in Member countries, but rather to illustrate and quantify the macroeconomic advantages and disadvantages of different approaches.

\subsubsection{Scenarios of public debt stabilisation}

67. The first scenario assumes that governments in the three main OECD regions control budget deficits strictly so that public debt ratios remain stable at their estimated levels at the beginning of the projection period (i.e. at around 23 per cent of GDP in Japan, 43 per cent in the United States and 57 per cent in the European Union), rather than rising as in the reference scenario ${ }^{35}$.

35. These specific assumptions for the levels of public debt are somewhat arbitrary and a number of alternatives can be envisaged as discussed in Sections 3.1.3 and 3.1.4 which follow. 
68. Given the implication of respective demographic trends in the reference scenario, this implies the introduction of somewhat more energetic measures in Japan and the European Union than in the United States (Figure 11, upper left panel). Overall, such policies are broadly consistent with the fiscal policy settings and plans discussed or announced in the three main OECD regions, which in most cases aim to reduce the generosity of pension and health-care systems and/or to increase taxes and social security contributions. In the European Union, besides the different social security reforms in progress or in preparation, the rules imposed by the Growth and Stability Pact associated with European Monetary Union tend to reduce de facto the risk of public deficit slippage and to limit, if not reduce, the public debt/GDP ratios of these countries. In Japan the authorities have introduced medium-term budget plans incorporating progressive increases in social security contributions and reductions in pension and health-care benefits so as to ensure long-term equilibrium of these social schemes ${ }^{36}$.

69. Hence, in this scenario, governments are assumed to stabilise debt primarily by moderating the rise in the share of public expenditures (both consumption and household transfers) in GDP ${ }^{37}$. The alternative of raising taxes would be a source of major distortions, notably in the labour market, and constitute a transfer of resources from younger to older generations which would be difficult to justify in terms of intergenerational equity $^{38,39}$.

70. The principal effect of stricter control of public deficits and debt is to permit a gradual easing of interest rates in all countries. Thus in this scenario, real interest rates fall over the period by between 1 and $1 \frac{1}{4}$ percentage points, depending on country and region (Figure 11, upper right panel) stimulating capital accumulation and growth of output in all regions (Figure 11, lower left panel). Whereas, in the main OECD regions, higher investment growth is financed by increased saving, the increase in demand and output in the largely non-OECD area is financed by higher external indebtedness (Figure 11, lower right). Thus GNP growth is higher than GDP growth for the main OECD countries, while the reverse is true for the largely non-OECD countries. The latter group of countries also experience some exchange-rate depreciation, conducive to a widening trade surplus, which in turn enables them to finance the servicing of higher net external debt.

71. Overall, measured in terms of per capita GNP, living standards in the main OECD countries increase relative to the reference scenario by between $3 \frac{1}{2}$ to $6 \frac{1}{2}$ per cent by 2050 , depending on country and region (Table 7). However, measured in terms of per capita consumption (both private and public), the gains are significantly smaller, of the order of 2 per cent by the year 2050. Moreover, these gains are obtained largely through reductions in the levels of per capita consumption of current generations, which stresses the inter-temporal transfer of resources implied by such a fiscal adjustment. Thus, as younger

36. In 1994, measures were introduced to raise the eligibility age for basic pensions to 65, while maintaining that for supplementary pensions at 60 . Growth of pension expenditures has also been limited by relating pensions to net instead of gross earnings. Measures have also been announced to progressively raise social security contributions, whilst hospital fees have been increased and new welfare contributions introduced [for more details see OECD Economic Survey: Japan (1997)].

37. Overall, this scenario assumes increases in expenditures about one-quarter of those in the reference scenario, whilst some complementary small increases in taxes and contributions are assumed to achieve stabilisation of debt at its initial level.

38. Comparable simulations suggest that debt stabilisation exclusively through higher taxes and contributions would require increases in tax rates by the year 2050 of the order of 17 percentage points of GDP in Japan, over 10 points in the European Union and 7 points in the United States.

39. Raising taxation is also likely to be less effective than reducing expenditures, in raising savings and production. An increase in public savings through higher taxes automatically places a burden on the incomes and savings of private sector agents, in particular those who are liquidity-constrained, which would tend to limit any increases in total savings and hence reductions in real interest rates. 


\section{ECO/WKP(98)6}

generations will certainly benefit from higher living standards than current generations, the consequences of such a policy in terms of equity and welfare appear to be ambiguous ${ }^{40}$.

72. The estimated improvement in living standards could understate the relative gain from tighter public spending controls inasmuch as the latter may be perceived as being more credible by financial markets and may therefore also reduce risk premia in the reforming countries. Moreover, the frequently cited option of reducing pension generosity would also tend to stimulate growth of labour supply and output, unlike the case where social security contributions are increased ${ }^{41}$. Whether through a lowering of replacement rates or a change in the pension indexation system, retirement age reforms reduce the incentive for agents to retire early. Yashiro and Oshio (1997) note, for example, that in Japan the participation rate for men over 60 tends to rise when the generosity of transfer incomes decreases. This type of endogenous reaction by the labour force to the fiscal reforms, which is not incorporated in this specific scenario, would further reinforce the positive effects of public expenditure controls ${ }^{42}$.

73. The estimated effects of fiscal consolidation on broad macroeconomic aggregates obtained are of the same orders of magnitude as to those reported by Ball and Mankiw (1995), who estimate that a 25 per cent reduction in the United States public debt would permit a fall in real interest rates of the order of .85 percentage points and a rise in GDP of 3 per cent ${ }^{43}$. The model developed by Faruqee et al. (1996) also provides similar estimates, with a reduction of net public debt by about 20 per cent of GDP in the OECD countries leading to a fall in real interest rates of up to .80 percentage points and an increase in GDP of about 3 per cent.

74. These broad magnitudes are high in relation to those obtained in many other studies (see, for example, Evans [1985]), particularly those which attempt to estimate the links between interest rates and public debt at the level of individual countries. The approach underlying the model projections in the present study as well as Faruqee et al. (1996) essentially relates a measure of the "world" interest rate to the savings-investment balance at the world level, which would seem to be more consistent with the increasing degree of financial market integration. This approach also underlies the econometric study of Ford and Laxton (1995) who obtain much higher estimates of the effects of changes in aggregate public debt of OECD countries on world real interest rates than is typically found in studying individual countries. Thus, according to this study, the observed rise of $18 \frac{1}{2}$ points in the net public debt/GDP ratio in the OECD area between 1978 and 1993 caused a rise of $2 \frac{1}{2}$ to $4 \frac{1}{2}$ percentage points in real interest rates ${ }^{44}$.

40. The framework used is not designed to make a detailed analysis of inter-generational equity issues. In the absence of public debt stabilisation, current generations benefit from faster consumption growth (in particular, public consumption) at the expense of the consumption growth of future generations. Thus, if welfare depends of both level and growth of per capita consumption, then public debt stabilisation might have more positive effects in welfare terms.

41. The expenditure reductions are assumed to exclude reductions in spending on infrastructure and human capital, which might otherwise have adverse effects on productive capacity.

42. A discussion of the effects of fiscal incentives on retirement and labour force participation is given in Sections 3.1.3 and 3.2 which follow.

43. Ball and Mankiw assume a closed economy and use an approach based on a simple accounting framework and a Cobb-Douglas production function rather than a full model. Hence they do not take into account the saving reactions and its impact on interest rates and output (see the Technical Annex for a more detailed discussion).

44. These estimates should be interpreted with caution, however, inasmuch as they are based on reduced form relationships between real interest rates and world public debt from which other possible influences, such as those coming from changes in risk premia or imperfections in financial markets, are omitted. 


\subsubsection{The benefits of international co-ordination of fiscal policies}

75. Overall, the influence of control of public finances would be all the more effective when conducted by Member countries in a co-ordinated manner. In effect, simultaneous action to increase public saving on an OECD-wide basis is likely to produce larger reductions in real interest rates and larger increases in output than could be achieved by individual efforts. At the same time, there is the question of whether a country which is small on the world scale would be sufficiently motivated to pursue a policy of public debt reduction on its own if the overall influence on interest rates and output are likely to be limited.

76. This is illustrated by an additional scenario which assumes that only Japan stabilises net public debt at its initial level. In this case, the effects are significantly smaller than in the case of co-ordinated action (Figure 12), with interest rates in Japan falling 1/4 percentage points by 2050, compared with $1 / 2$ percentage points in the case of OECD-wide action. At the same time, a country which conducts fiscal consolidation on its own is likely to achieve a larger increase in its current balance (in the case of Japan by more than 2 percentage points per annum of GDP between 2000 and 2050) and a correspondingly larger rise in its stock of net external assets ${ }^{45}$. Such developments would produce stronger growth in per capita GNP for Japan than in the other countries (Table 8), but the overall effects on living standards would nevertheless be less favourable in all countries and regions than in the case of co-ordinated action (Table 7).

\subsubsection{Debt stabilisation with an increase in the age of retirement}

77. While reductions in pension generosity and increases in welfare contributions are often cited as necessary reforms to prevent excessive pressure on public finances, a further option frequently envisaged is to raise the retirement age ${ }^{46}$. Such reforms might take place in two ways; by raising the age of eligibility for fullrate benefits or by increasing the number of years of activity and contributions required for full-rate benefit, with benefits being reduced on an actuarial basis for each year of early retirement.

78. From a macroeconomic viewpoint, raising the retirement age is an attractive option, especially in countries where the normal age of pension eligibility is comparatively low and where the effective age of retirement is visibly below the "normal" age. Potentially, such reforms both reduce pension expenditures and increase the labour supply, thereby increasing output and overall revenues from social contributions and taxes on earnings.

79. An additional scenario illustrating the effects of this type of reform, assumes that the retirement age in the main OECD regions gradually rises by five years, up to a maximum of 70 years (Table 9) ${ }^{47}$. Figure 13 shows the corresponding effect on pension system balances for the three main OECD regions (see Technical Annex for more details). As in the previous scenarios, governments are assumed to stabilise public debt at initial levels. An estimate of the effects of increasing labour force participation rates is also incorporated.

45. Over the 2000-2015 period for example, the Japanese current account surplus would rise progressively to about 4 per cent of GDP as compared with 2 per cent or less in the reference scenario, with the effect of increasing current account imbalances between regions.

46. The notion here of raising the retirement age entails changing policies that affect the incentives to retire or not, policies that are currently biased towards early retirement in many countries [see Blondal and Scarpetta (1998)].

47. No increase in the retirement age is assumed for the United Kingdom which is one of the few OECD countries in which the financial balance of public pension schemes do not appear to be threatened by the effects of population ageing [see Roseveare et al. (1996) and Chand and Jaeger (1996)]. 


\section{ECO/WKP(98)6}

Given the expected demographic trends in the different regions and the extent of the reforms, such increases are more marked in Japan (over 10 percentage points by 2025) than in Europe and the United States (Figure 14) ${ }^{48}$.

80. The main outcomes of this scenario, reported in Figure 15 and Table 10, suggest effects on output which are potentially much larger than (by a factor of three or more) those of the previous debt stabilisation scenarios (see Figure 11). Indeed, with higher employment available as a result of higher participation rates, potential output growth is raised relative to the reference scenario in Japan by more than $1 / 2$ percentage per annum over the period to 2040, with similar increases for Europe and the United States but over shorter periods. This higher output growth tends to raise real interest rates until 2020-2030, but beyond this period higher public and total saving reduces the pressure on capital demand. Compared with the reference scenario, such a reform also has very appreciable effects on living standards by 2050 which, measured in terms of per capita GNP, are raised by 18 per cent in Japan, 14 per cent in Europe and 10 per cent in the United States, (Table 10).

\subsubsection{The timing of reforms}

81. One of the most important considerations regarding the relevant reforms is their timing. Appropriate fiscal measures, such as reducing pension generosity or increasing the age of pension eligibility, do not easily command a consensus among the population, especially in countries of high unemployment ${ }^{49}$. Yet postponement of action carries the risk of having to introduce more drastic reforms later on $^{50}$. Furthermore, it is important to give agents sufficient warning to enable them to adjust to inevitable changes in pension systems. In spite of the fact that ageing is occurring less rapidly in the United States and the European Union both these two regions face the same challenges in the longer term and will therefore need to use the intervening period to improve the state of public finances and increase their net external assets. Indeed, such a policy stance is consistent with those currently adopted in both regions over the medium term.

82. The final two scenarios presented in this section therefore attempt to illustrate, respectively, the effects of additional fiscal consolidation in the United States and the European Union between now and 2020, and the effects of delays in introducing retirement age reforms for the OECD area as a whole.

83. In the first of these, the broad assumptions are similar to those incorporated in the later retirement age scenario, except that for the United States and the European Union public debt levels are assumed to be reduced by 20 percentage points of GDP by 2020, and maintained at the implied lower ratio ( 23 and 37 per cent of GDP for the United States and the European Union respectively) thereafter ${ }^{51}$. Compared with the later retirement age scenario, such a policy would have the effect of further reducing interest rates and increasing their net external

48. The relative size of effects of later retirement age on overall participation rates is essentially explained by two factors: first, the additional years that agents are assumed to work relative to the reference scenario and, second, the age structure of the population (the more a population ages, the greater the number of persons affected by later retirement). For Japan, these two factors operate more strongly than in the case of the United States and the European Union. As in Roseveare et al. (1996), these participation rate effects may be overestimated to the extent that the participation rates of persons whose retirement is postponed are assumed to be the same as the average participation rate of the working age population.

49. Although, as discussed below and elaborated in Blondal and Scarpetta (1998), there are other policy options which, by affecting the retirement decision, can result in an increase in the age of retirement.

50. Various studies, e.g. Chand and Jaeger (1996), have quantified the cost of delays in introducing fiscal reforms in terms of additional increases in taxes and contributions to ensure the financial equilibrium of pension schemes.

51. Such reductions in the debt ratio are not particularly ambitious and are broadly consistent with the assumption of maintenance of budget balances at recently projected levels for example as in the medium-term reference scenario reported in Economic Outlook No. 62. 
assets (Figure 16). The additional output gains resulting from a further fall in real interest rates are estimated at about 1 per cent for most countries by the year 2050. Relative to the later retirement age scenario, the increase in living standards in terms of the levels of per capita GNP is slightly higher (up by 2 per cent) in the United States and the European Union than elsewhere. This difference reflects the rise in the foreign investment income of these two regions, consistent with the further increase in their national savings (Table 11).

84. The second scenario incorporates the assumption that retirement age reforms are implemented ten years later than previously envisaged and that governments do not succeed in stabilising debt until 2015. As a result debt ratios rise by up to 20 percentage points of GDP in Japan, but only marginally so in the United States and the European Union (Figure 17). As a result, living standards rise less than if reforms are implemented earlier. As might be expected, the differential is widest during the early part of the projection and by 2030 the increase in per capita GNP is 3 per cent less on average than in the earlier case (Table 12). The differential in estimated living standards between the two scenarios persists even over the longer term, particularly in the case of Japan, largely reflecting higher debt levels when reforms are delayed.

\subsection{Market reforms, labour force participation and factor efficiency}

\subsubsection{The effects of higher labour force participation rates}

85. The extent to which a decline in the population of working age translates into a proportionate decline in the labour force depends crucially on the evolution of participation rates. The reference scenario assumes that age-specific participation rates remain constant over time (at their 1995 levels), implying that between year 2000 and 2030, the labour force could decline by 13 per cent in Japan and 16 per cent in the European Union, but increase by 9 per cent in the United States. However, this ignores the possible influence on participation rates from both market incentives (i.e. real wages) and, more importantly, from various tax and benefit incentives which influence the "reservation wage".

86. In principle, the relative scarcity of labour arising from the decline in the working-age population may be expected to put upward pressures on the level of real wages and so generate an increase in the participation rate across age groups. However, two factors suggest there may be only a limited response of participation rates to real wage developments. First, as implied by the reference scenario, real wage gains may be offset by higher taxes and social contributions needed to finance the increasing pension and health care burden. Second, the bulk of empirical evidence tends to suggest that the aggregate response of labour supply to real wages is relatively small [see, for example, Card (1994)].

87. However, a number of recent studies suggest that participation rates may be quite sensitive to specific social and fiscal programme incentives. In Japan, the female participation rate remains relatively low, despite having risen over the past twenty years. Only 50 per cent of working-age women in Japan are in the labour force compared with about 56 per cent in the United States and some European countries. In particular, the participation rate of women aged between 30 and 45 years is very low (only 40 per cent) even though 60 per cent of the women who are not working in this age group have expressed the desire to join the labour market. This behaviour might partly reflect the current fiscal regime, according to which married women lose important fiscal deductions and retirement benefits as soon as their incomes exceed a relatively low level (OECD Economic Surveys, Japan, 1997) ${ }^{52}$.

52. Yashiro and Oshio (1997) present empirical evidence which suggests that female workers in general as well as older male workers tend to be particularly sensitive to changes in social security policies. 


\section{ECO/WKP(98)6}

88. More importantly, as reported by Blondal and Scarpetta (1998), tax and benefit incentives appear to have powerful effects on the participation rates of age-groups approaching normal retirement age ${ }^{53}$. Labour force participation rates of older workers (above 55) have declined markedly since the mid-seventies across most OECD countries, with the decline more pronounced in Europe and the United States than in Japan ${ }^{54}$. While the trend increase in the wealth of households explains much of the movement towards early retirement, there is strong evidence that policies specifically designed to encourage older workers to withdraw from the labour force have also played an important additional role, especially in Europe where such schemes have sometimes been used as a means to lower the unemployment rate (OECD Jobs Study, 1994).

89. Summarising the evidence from a collection of country-specific studies, Gruber and Wise (1997) cite numerous examples of cross-country differences in participation behaviour which appear to be at least partly explained by differences in the treatment of taxes and benefits. Among the main findings, they report that the replacement rate at the official early retirement age (around 60 years in most countries) is close to 70 per cent in the European Union (varying between 48 per cent in the United Kingdom to 91 per cent in France), compared with 54 per cent in Japan and 41 per cent in the United States. In many countries, disability and unemployment programmes effectively provide early retirement benefits even before the age at which workers are officially entitled to such benefits ${ }^{55}$. Moreover, as also shown by Blondal and Scarpetta (1998), in some cases policies designed to provide early retirement have been found to contain provisions that imply large financial penalties on labour earnings for those who would otherwise prefer to remain in the labour force beyond the official retirement age. Gruber and Wise calculate implicit tax rates on earnings in the first year after eligibility for early retirement of about 80 per cent in several European countries (Belgium, France, Italy and the United Kingdom), compared with 47 per cent in Japan and zero in the United States ${ }^{56}$. Thus the elimination of incentives which encourage early retirement and the setting-up of actuarially neutral pension systems might promote substantially higher participation rates, especially in Europe.

90. To illustrate the potential benefits of raising participation rates, an alternative scenario is presented based on two key departures from the assumption of constant age-specific participation rates. First, it is assumed that the low participation rate for females aged between 30-45 years in Japan gradually rises to those observed for the age groups $20-30$ and $45-50$ years ${ }^{57}$. This has a peak effect of raising the labour force by about $2 \frac{1}{2}$ per cent by 2020 , see Figure 18 . Second, it is assumed that the participation rates of older workers in the

53. Given the projected evolution of the age structure, any changes in the participation rates of the age groups between 50 and 65 will likely dominate the evolution of the aggregate participation rate over the coming decades.

54. While there has been a widespread decline in the participation rates of males between 55 and 64 years across the OECD area since 1975, the steepest declines have taken place in Finland, France, the Netherlands and the United Kingdom. The smallest declines are found in Japan, the United States and Sweden. In Japan, since 1975 the participation rate of male workers of age 55-59 has even risen marginally. The participation rate of older categories has also risen since the mid-80s in Japan.

55. In many cases, there are additional pressures for early retirement from business managers who often perceive older workers as being more costly, less productive and less adaptable to new skills than younger workers. A recent OECD study [Casey (1997)] suggests, however, that these perceptions are not well founded.

56. Within the European Union, Germany and Spain have relatively low implicit tax rates at 35 per cent and 23 per cent, respectively.

57. A similar assumption is made by Yashiro and Oshio (1997) in their baseline simulation of the effect of ageing in Japan. 
United States and the European Union (aged 50-65 years), gradually increase over time to reach the rates observed for the same age categories in Japan by $2035^{58}$.

91. These assumptions imply increases in the participation rates of older workers of about 10 and 23 percentage points for the United States and the European Union respectively, with corresponding increases in the labour force of up to 8 per cent for the United States and 19 per cent for the European Union (Figure 18$)^{59}$. The effects on the European Union are larger, reflecting the combination of two factors: the increase in older workers' participation rates is larger than for the United States; and older workers constitute a much larger proportion of the population than in the United States (see Figure 2).

92. The key results for the alternative scenario, which also incorporates a reduction in European unemployment rate from $9 \frac{1}{2}$ per cent to $5 \frac{1}{2}$ per cent, are shown in Table 13 and Figure 19 . By raising the labour supply and employment, the main effects of these changes is to increase average GDP growth between 2000 and 2040 by more than $1 / 2$ per cent per annum for the European Union and $1 / 4$ per cent for the United States (Figure 19). In the longer run, the effects of permanent increases in the labour force and employment are reflected in almost proportionate increases in the levels of output and living standards (Table 13), which leave real interest rates virtually unchanged. However, during the transition period, output and living standards rise less than proportionately because real interest rates also rise. This increase (together with a decline in net foreign assets) is triggered by the increased investment requirement of (temporarily) higher output growth, combined with a temporary decline in savings as consumers anticipate higher levels of future production $^{60}$.

\subsubsection{Improvements in total factor productivity}

93. For most countries, over most periods, growth in living standards in the reference scenario is dominated by growth in total factor productivity. Thus, in a situation in which ageing threatens future living standards, a natural focus is on policy measures which promote improvements in total factor productivity. Numerous empirical studies have attempted to link total factor productivity growth with sources which have immediate relevance to policy [see Richardson (1997) for a review of the evidence].

94. Policy reforms may lead to either static gains (i.e. once and for all shifts in the level of GDP through more efficient resource allocation) or dynamic gains (i.e. permanently affecting GDP growth rates). Clearly policies which permanently raise total factor productivity will have (increasingly) large effects on living standards. However, many of the policies which empirical studies suggest might produce such dynamic gains (such as increased openness or a stable macroeconomic environment with low inflation) may be largely in place in most OECD economies (although there may be substantial dynamic gains to be had for many developing

58. As in Yashiro and Oshio (1997), it is assumed that the labour force participation rate for older workers remains relatively high in Japan. In contrast, Ando (1996) examines the effect of a reduction in participation rates for older workers on private savings in Japan.

59. Taken over the next few decades, such changes, which may appear particularly large for the European Union, are not implausible given a suitably ambitious programme of pension and labour market reforms. On the basis of the estimates reported in Blondal and Scarpetta (1998), the combined effects of moving to actuarially-neutral pension systems, raising the retirement age by five years in a number of countries and lowering the structural unemployment rate to 5.5 per cent would be sufficient to raise participation rates of older male workers in Europe by as much as 16 to 20 percentage points by 2035 . On the same basis for the United States, a reform of the pension system combined with demographic trends reducing the share of prime-age workers in the total working age population would boost participation rates of older workers (55-64 years of age) by 10percentage points.

60. However, there may be some offsetting boost to savings (not incorporated in the simulation) as older workers who stay in the workforce tend to save more than if they had withdrawn (see Cordoba, 1996). 


\section{ECO/WKP(98)6}

economies). Thus, to illustrate the potential benefits of improvements in total factor productivity the more modest static gains which might follow the specific case of regulatory reform in the OECD are considered.

95. Regulatory reform, which has already gained momentum in the OECD area over the past decade, would reduce costs and inefficiencies by boosting competition. The potential gains from the implementation of ambitious, but not unprecedented reforms in five sectors (electricity, airlines, road transport, telecommunications and distribution) have recently been evaluated and might eventually raise the level of GDP by 5.9, 4.3 and 0.9 per cent in Japan, the European Union and the United States, respectively ${ }^{61}$. Assuming such reforms were extended to other sectors - such as agriculture, public administration, professional services, other transports and manufacturing - then the benefits would be much larger and, for illustrative purposes, a scenario has been constructed assuming these gains are approximately double those identified. Such reforms are assumed to take effect gradually over the period 2000-30 for the United States and the European Union, and over the period 2000-20 for Japan (reflecting the greater urgency in the case of Japan to offset the influence of ageing).

96. The results reported in Table 14 and Figure 20, suggest that the gains in living standards while reforms are being implemented are roughly two-thirds of the gains in labour efficiency. The main offset comes from the positive influence of faster growth during the adjustment period on domestic interest rates which reduces capital deepening. However, in the longer term, once output return to its equilibrium growth path the overall increase in the level of living standards rises close to the full gains in labour efficiency. Overall, these estimates suggest that such regulatory reform might eventually raise living standards in the United States, the European Union and Japan by 2, 7 and 10 per cent respectively.

\subsection{Foreign investment and its role in supporting future living standards}

97. An important question raised by a number of recent studies concerns the possible contribution which increased foreign investment by OECD countries, particularly in the non-OECD, might make to support OECD living standards in the face of ageing populations. As reported in section 2, the contribution from foreign investment income to the growth in living standards in the reference scenario is relatively modest (Figure 10) - accounting for less than $1 / 4$ per cent per annum of growth in living standards for the main OECD regions. Indeed, for the area as a whole, the contribution from net foreign investment income becomes negative before 2050 as net foreign assets are progressively run down. However, since the reference scenario incorporates substantial reductions in private and public saving in the main OECD regions, it is useful to ask whether, under alternative assumptions (reflecting, for example, different policies) investment income might play a more substantial role.

98. The case for the OECD building-up its net foreign asset position vis-à-vis the non-OECD is mainly based on the possibilities for higher expected returns compared with domestic investment alternatives, particularly if increased saving, when channelled into domestic investment, tends to depress the rate of return on capital $^{62}$. Two recent studies, Mackellar and Reisen (1997) and Bosworth and Burtless (1997), examine the effects of increased foreign investment in the context of ageing populations using different approaches. The former study uses a two-region model of the world economy to analyse the effects of increased financial

61. See Blondal and Pilat (1997).

62. A further advantage of OECD countries accumulating assets in the non-OECD region, which is not considered in detail here, is that the correlation of returns across the two regions is relatively low compared to that between OECD countries (Reisen 1997), although some authors, for example, Blommestein (1997) are sceptical whether such a low correlation will persist. By diversifying their portfolios, OECD investors could thus lower their risk for any given level of return. 
integration between the OECD and non-OECD. The latter uses a model of the United States economy to compare the effects of increased saving, invested alternatively in domestic and foreign assets. Both models are essentially neo-classical and, although they differ in a number of important respects, the main findings appear to be broadly similar ${ }^{63}$.

99. In both cases, the effects on aggregate income are small, even over time horizons extending to 2050. Thus, in Bosworth and Burtless (1997), whether a given increase in saving is invested domestically or abroad makes very little difference to per capita consumption or GNP. Similarly, Mackeller and Reisen (1997) report changes in aggregate consumption and GNP of the order of a few per cent (consumption is slightly reduced and GNP slightly increased) as a result of fairly major shifts in the holdings of non-OECD assets by OECD pension funds ${ }^{64}$. The main explanation for these results is that, to the extent that higher foreign investment implies foregone domestic investment, there is a consequent loss in domestic productivity and wage income, which broadly offsets the gains from increased foreign investments. As a result, the most striking effects of higher OECD investments in the non-OECD regions are found to be on the distribution of income: increased foreign investment raises income on capital (a large element of which accrues to pension funds) whereas domestic investment raises the incomes of wage earners ${ }^{65}$.

100. Cutler et al. (1990) use a simple optimal growth model to calculate the optimal path for consumption in response to ageing for the United States and other OECD economies. A comparison of the response of the non-US region when it is considered as a closed economy and when it is open to the United States suggests that for the faster-ageing region the possibility of accumulating foreign investment raises consumption in the long run, although the magnitude of the effect is not large (the level of consumption is about $1 \frac{1}{2}$ per cent higher). Bosworth and Burtless (1997), however, note that the potential gains from foreign investment (particularly for the United States) are likely to be under-estimated because the non-OECD region is ignored in this analysis.

63. The two-region (OECD and non-OECD) model used by MacKellar and Reisen (1997) is based on a two-factor neo-classical growth model with differing propensities to save out of profits and wages, where age-specific household saving rates are assumed to be exogenous. There is no explicit exchange rate and rates of return are determined by the marginal productivity of capital in the respective regions. The model is solved for three 'snapshot' years: 1995, 2020 and 2050. Bosworth and Burtless (1997) use a neo-classical model of the United States where rates of net saving are controlled exogenously and investment is disaggregated into five categories. The exchange rate is exogenous and alternative simulations demonstrate the importance of alternative assumptions regarding the behaviour of the exchange rate. The rate of return to business investment in the United States is determined by the marginal productivity condition, but the rate of return on foreign investment is assumed to be fixed and the extent of foreign investment is determined exogenously. The model is solved to 2050, although much of the emphasis is placed on the differences from the baseline of alternative investment strategies.

64. Two "financial integration" scenarios are considered: in the first the share of OECD savings invested in the nonOECD rises from less than 2 per cent in 1995 to 10 per cent by 2020; in the second the share rises to 15 per cent by 2020 and remains at this higher level to 2050. The results from these scenarios are compared with a baseline in which the proportion of OECD savings invested in the non-OECD remains stable.

65. Higher domestic investment raises domestic productivity and hence wages and, at the same time, depresses the domestic rate of return on capital. Conversely, higher foreign investment is assumed to deliver a higher rate of return than domestic investment, but there is no direct effect on domestic productivity and, hence, domestic wages. Bosworth and Burtless (1997) note that if limiting the social security burden on future generations is a major policy objective, then foreign investment might be preferred over domestic investment because it would reduce the increase in future social security benefits, given that under the US social security system - as in many other OECD countries - real pension benefits are determined by past real wages. 


\section{ECO/WKP(98)6}

101. Simple "back-of-the-envelope" calculations made on the basis of the reference scenario also suggest that increased foreign investment is not a general panacea and can make only a modest contribution to offsetting the projected decline in the growth rate of living standards relative to past trends ${ }^{66}$. A more complete analysis of the potential benefits of the accumulation of net foreign assets, allowing for a range of feedback effects (on interest rates, exchange rates, productivity, etc.) requires a more careful distinction between two possible causes of such an accumulation: an increase in OECD savings; and an increase in the demand for capital from the non-OECD.

102. The effects of an increase in OECD savings on net foreign asset positions and investment income depend crucially on how widespread it is across OECD countries. Thus, for example, if a single OECD economy undertakes sustained fiscal consolidation, much of the decline in public debt will be reflected in increased net foreign assets and much of the gain in living standards will come about through higher investment income. This is illustrated in the earlier case of Japan (section 3.1.2, Table 8 and Figure 12) where a large reduction in public debt (relative to the reference scenario) of about 75 per cent of GDP by 2050 is matched by a more-or-less equivalent increase in net foreign assets. By 2050, the fairly modest increase in per capita living standards of about $4 \frac{1}{2}$ per cent relative to baseline is almost entirely accounted for by an increase in investment income $^{67}$. By contrast, where the same fiscal consolidation is undertaken by Japan as part of OECD-wide fiscal action (see 3.1.1, Table 7 and Figure 11) the increase in Japan's net foreign assets is equivalent to only twothirds of the reduction in public debt. Moreover, the corresponding increase in living standards (7 per cent by 2050) while somewhat greater than when Japan alone takes fiscal action, is mostly accounted for by capital deepening as opposed to foreign investment income ${ }^{68}$.

103. This result is explained by the fact that an OECD-wide fiscal consolidation would lead to a significant reduction in world interest rates (whereas Japan acting alone would not). This encourages domestic capital accumulation and leads to higher productivity but, at the same time, reduces the return on foreign investments. This would suggest that the scope for increased national saving making a (modest) contribution towards maintaining living standards, through higher net foreign investment income, is greatest in those (particularly small) OECD countries where ageing is occurring most rapidly. Conversely, the scope for all OECD countries to support living standards from higher investment income earned on net foreign assets is likely to be extremely limited. Besides, such gains in living standards would, in the longer-run, come largely at the expense of the current generation, which raises the question of inter-generational equity.

66. To take an extreme example, in the case of Japan, the projected decline in the level of living standards relative to a trend annual growth of, say, 2 per cent amounts to 18 per cent by 2030 (Table 5) with perhaps two-thirds of this decline directly accounted for by the rise in the dependency ratio. Assuming an average rate of return on foreign assets of about 7 per cent, Japan's net foreign assets would need to increase by over 330 per cent of GDP by 2030 in order to provide sufficient investment income to fully offset such a loss in living standards. For Europe and the United States, the corresponding estimates of the required increases in net foreign assets by 2030 are 230 per cent and 270 per cent of GDP respectively. Such increases are generally implausible in relation to the reference scenario.

67. In this case, the estimated increase in investment income is quite similar to that obtained from the "back-of-the-envelope" calculation described in the previous footnote. These calculations may however underestimate the contribution from investment income by being based on net foreign asset holdings and not the difference between investment income flows on gross asset holdings. More detailed analysis of the latter approach will be the subject of further development of the Minilink model structure.

68. Hence, the increase in investment income is significantly smaller than suggested by "back-of-the-envelope" calculations. 
104. A greater build-up in net foreign assets held by OECD countries might also occur if the non-OECD demand for capital was significantly higher than projected in the reference scenario ${ }^{69}$. An alternative scenario, based on the assumption that labour efficiency in the two mainly non-OECD regions grows by an additional 1 per cent per annum over the period to 2050, suggests a very substantial additional build-up in net foreign assets in the three main OECD regions, of between 60 and 80 per cent of GDP by 2050 (see Table 15 and Figure 21) ${ }^{70}$. The associated improvement in the level of living standards in the main OECD regions, of between 7 and $91 / 2$ per cent by 2050 , is broadly equivalent to a quarter of the loss in living standards relative to past trends (Table 5). The main contribution to this relative improvement comes from higher net foreign investment income, although an improvement in the terms of trade also makes a substantial positive contribution. An increase in the demand for capital from the non-OECD regions boosts OECD net foreign investment income by a larger amount than a similar increase in OECD savings because it also raises the rate of return.

105. An important qualification to these results is that such a change in the distribution of investment would require a significant reduction in the current impediments to capital mobility and considerable further development of non-OECD capital markets. Currently, there are important regulatory barriers, which for example, require pensions funds and other institutional investors in many OECD countries to allocate their portfolios in a way which is biased towards domestic assets [World Bank (1997) and Reisen (1997)]. Furthermore, many non-OECD economies are not very attractive to invest in because of "fragile banking systems, illiquid and poorly-regulated stock markets and political risk" (Blommestein 1997), which also constitute effective barriers for OECD pension funds and other institutional investors. In the present simulations, such impediments to capital mobility are modelled by premia on capital in the mainly non-OECD regions. However, these almost certainly do not adequately capture the strains on capital markets which might occur if many non-OECD countries were to run large and sustained current account deficits (as demonstrated by the experience of Mexico and, more recently, countries in South East Asia).

106. Overall, the broad conclusions from this analysis are as follows:

- the accumulation of the net foreign assets in an OECD country, particularly a small country which faces ageing soon, might provide a small but significant contribution to living standards though future net investment income. However, given the potentially adverse effects on domestic productivity of shifting investment away from domestic sources, such effects are likely to be very limited in offsetting the effects of ageing;

- the scope for many/most OECD countries to obtain such beneficial effects may be even more limited, given that increased investment in the non-OECD will progressively lower the return on such investments;

- a major uncertainty concerns the future growth potential of the non-OECD region over the coming decades. Given a considerably more optimistic outlook for the non-OECD, based, for example on the assumption of major supply-side reforms, there would be greater scope for OECD investment in those regions. In such a "high-performance" scenario, the rate of return earned on

69. The projections for labour efficiency growth in the reference scenario are broadly consistent with those in the "business-as-usual" scenario to 2020 outlined in OECD (1997). However, in the same study, an alternative optimistic "high-performance" scenario is considered which assumes that labour efficiency growth in the nonOECD is raised by up to $2 \frac{1 / 4}{4}$ per cent per annum, as a result of an intensification of supply-side reforms to improve the structure and flexibility of markets.

70. These "improvements" are relative to the reference scenario in which net foreign assets are $-16,-13$ and +40 cent of GDP by 2050 for the United States, Japan and the European Union respectively. 
accumulated assets might also be substantially increased, so that investment income flows would provide a more substantial offset to the adverse effects of ageing on OECD living standards. However, for the OECD to reap such benefits there would have to be major structural change in the non-OECD economies, not only in product and labour markets, but also in capital markets, to facilitate the massive resource transfers involved.

\subsection{The effects of combined reforms}

107. Overall, the estimates presented in the previous sections suggest that a range of measures and reforms would help limit the unfavourable macroeconomic consequences of population ageing. However, the impact of the different policies vary significantly across regions. In the European Union and, to a lesser degree, the United States there appears to be very considerable scope for increasing the labour force and employment, notably among older workers, and hence productive capacity. In Japan, and also the European Union, the potential macroeconomic gains in terms of labour efficiency are very large. In all countries the implementation of reforms to ensure strict control of public expenditures and debt should make it possible to achieve a significant rise in output and incomes.

108. However, none of the specific policy measures considered, taken in isolation, is likely to make a significant dent in the projected decline in growth in living standards. Moreover, reforms implemented in the different spheres concerned are likely to be closely interdependent. Thus, in some countries, raising the eligibility age for full-rate pension benefit may have only limited effects on participation rates if financial incentives and welfare programmes which encourage early retirement are not also modified. Similarly, postponing retirement will do little to raise output if markets, especially labour markets, are not flexible enough to ensure that jobs are actually created. Higher labour force participation of older workers, whose presence should increase in the years to come, would be facilitated by specifically targeted training and education policies to improve their efficiency. Labour efficiency would be reinforced by reforms in regulations and the further opening of certain markets still protected from competition, and by increased investment. One of the most direct means of stimulating investment sustainably is to encourage a fall in real interest rates through coordinated policies for growth of public saving across OECD countries. All told, it is through a set of coherent combined reforms, under a strategy co-ordinated at international level, that the most substantial macroeconomic effects are likely to be achieved.

109. Figure 22 and Table 16 summarise the potential impact that such a package of combined reforms might have on the macroeconomic performance of the main OECD countries by the year 2050, based on a set of measures comprising:

- stabilisation of the net public debt in Japan at its estimated level for 2000; reductions of net public debt in the United States and the European Union to 23 and 37 per cent of GDP respectively by 2020 , followed by stabilisation thereafter;

- progressive raising of the retirement age by 5 years in the main OECD countries as from 2005, with the package of reforms discussed in Blondal and Scarpetta (1998);

- a reduction of structural unemployment in Europe to $5 \frac{1}{2}$ per cent by 2010;

- regulatory reforms which increase the level of labour efficiency above its underlying trend, amounting to 10 per cent in Japan by 2020 and approximately $81 / 2$ and 2 per cent respectively in the European Union and the United States by 2030. 
110. Relative to the reference scenario, these combined reforms are estimated to raise output levels by over 40 per cent in the European Union, 30 per cent in Japan and 15 per cent in the United States by 2050; equivalent to increases in average growth rates of $3 / 4$ percentage point per annum over the period for the European Union, $1 / 2$ percentage point per annum for Japan and $1 / 4$ percentage point per annum for the United States. Until about 2030, real interest rates would be higher than in the reference scenario, notably in Japan and the European Union, before turning down steeply (Figure 22). Unlike the United States, net external assets for Japan and the European Union decline by about 10 to 15 percentage points of GDP between 2010 and 2020 relative to the reference scenario, reflecting the initial acceleration of growth. Subsequently, however, the main OECD regions experience improvements in net external positions vis-à-vis the mainly non-OECD region, tending to offset, at least partially, the large fluctuations in net external assets present in the reference scenario.

111. With these combined reforms, living standards between now and 2030 are estimated to grow on average by over 2 per cent per annum in Japan and about $1 \frac{1 / 2}{2}$ per cent per annum in the United States (Figure 23). Such rates, which are broadly comparable to those recorded in the 1970s, ease subsequently though remaining relatively buoyant. The potential average growth in living standards for the European Union is even stronger. In the reference scenario, Europe is relatively unaffected by the effects of population ageing up until 2020 and, benefiting from fairly robust growth in labour efficiency, experiences relatively strong growth in living standards, which rise by an average $1 \frac{3 / 4}{4}$ per cent per annum (Table 5). Given the further scope in the region for reducing structural unemployment, raising participation rates, increasing labour efficiency and achieving fiscal consolidation, the combined reform strategy implies growth in living standards of $2 \frac{1}{2}$ per cent per annum up to 2030, i.e. a rate higher than any recorded in the region since the early 1970s. 


\section{Box 1. Overview of Minilink}

Minilink is a multi-region dynamic general equilibrium macroeconomic model of the world economy designed to examine policy issues over a time horizon of many decades (see the Technical Annex for a more comprehensive description). The model separately distinguishes five-regions: the United States, Japan, Europe, and fast- and slow-ageing "rest of the world" regions. Three types of agent -- households, firms and government -- interact in markets for goods and financial assets. Each region is assumed to produce a single good, which is an imperfect substitute for the goods produced by other regions. Two sorts of financial asset are distinguished, bonds and physical capital. The rate of return on physical capital assumed is to be generally higher than that on bonds due to the presence of equity risk premia. Rates of return on bonds, or physical capital, differ across regions according to expected changes in the exchange rate and differences in sovereign risk premium, with the latter assumed to be higher in non-OECD regions. Given the long-term perspective of the model, assets stocks drive behaviour: investment is determined to generate the required capital stock; consumption is determined as a proportion of household wealth; and fiscal policy is conditioned by the need to ensure that governments achieve target debt-to-GDP ratios.

In equilibrium, real interest rates in all regions are assumed to converge on a single world rate, one which ensures global consistency between demand and supply, with exchange rates and net foreign assets positions adjusting to ensure consistency within individual regions. This equilibrium is calculated for a point in time well beyond the period of interest (typically more than a century into the future), to provide "terminal conditions" for the "model-consistent" forward-looking expectation variables, notably exchange rates and real interest rates.

Other key features of the model are as follows:

production technology is characterised by a two-factor (capital and labour) constant-returns Cobb-Douglas function with exogenous labour-augmenting technical progress. Factors of production are assumed to be fully utilised.

with respect to demography, the model distinguishes between the share of populations above, below and of, working age. These variables influence private savings/consumption behaviour and government spending (see below). In determining the labour force, more detailed information on the structure of the population of working age is used in conjunction with agespecific participation rates.

governments are assumed to raise taxes on labour income, purchase consumable goods and make lump-sum transfers to households for various social benefit purposes, including provision of pensions. Government expenditures on health and education are modelled separately and are sensitive to demographic factors.

consumer behaviour is based on an extended version of the Blanchard (1985) model of "perpetual youth", with aggregate consumption determined as a proportion of the stock of total (human and financial) wealth. The propensity to consume out of wealth is directly related to the "probability of death", changes in which are assumed to follow changes in mortality rates implied by demographic projections. This provides a mechanism by which ageing populations have life-cycle effects on aggregate consumption. Human wealth is measured as the present value of future net labour income to all consumers that are currently alive and, following Faruqee et al. (1997), labour income is assumed to have an age-specific "hump-shape" profile which declines rapidly with old-age. This latter feature considerably increases the degree of non-Ricardian equivalence, a characteristic further enhanced by the assumption that some consumers are liquidity-constrained.

1. Minilink has many broad characteristics -- particularly the importance of asset stocks, the use of model-consistent expectations and the determination of technical conditions -- in common with Ralph Bryant's two-region model of the world, see Bryant and Zhang (1996a and $b$ ) and especially Bryant (1998). Bryant's model in turn draws heavily on the IMF's world model, Multimod, see Masson et al. (1990). 
Box 1. (contd.)

International trade is assumed to take place only in consumption goods and is determined according to a two-step procedure based on the Armington (1969) framework. Import volumes are first determined by consumption demands and relative prices and are then allocated between regions through a set of export share equations incorporating competitiveness effects to ensure global consistency of world trade. Export prices are assumed to be identical to be domestic production prices, with import prices determined as trade weighted averages of export prices.

As described in section 2.2.2, the pressures on savings and investment in the reference scenario originate from three main sources: a world-wide slowdown in growth; a decline in the weight of the OECD in world output; and the negative impact of demographic changes on savings, concentrated in the OECD. Each of these influences is examined in isolation below, using simulations of a simplified 2-region version of Minilink ${ }^{2}$, with particular emphasis on the comparative responses of interest rates, exchange rates and net foreign assets, as shown in the figure below. 


\section{Box 2. Decomposition of key demographic influences in the reference scenario}

i)

A world-wide slowdown in growth (row 1)

This simulation features a gradual slowdown in growth in OECD and non-OECD regions by about 1 per cent per annum between 2000 and 2080, caused by a decline in population growth ${ }^{3}$. This slowdown reduces the marginal productivity of capital and so reduces interest rates in both regions, by an equivalent amount. At the slower growth rate, less investment is needed to maintain the required capital stock and lower interest rates lead to a decline in private savings by an equivalent amount. Given that the decline in growth rates is the same in both regions there is virtually no effect on exchange rates or net foreign asset positions ${ }^{4}$.

ii)

A decline in the weight of the OECD in world output (row 2)

This simulation features a decline of the OECD share in world output, from about 60 per cent in 2000 to just over 40 per cent by 2100 . This reduction is brought about through a gradual (but temporary) reduction in OECD population growth. Initially, slower growth in OECD demand for imports, relative to the growth in non-OECD demand for imports, leads to larger OECD current account surpluses and a corresponding build-up of net foreign assets. Given the slower growth in the OECD and the implied decline in the marginal productivity of capital, there is downwards pressure on OECD relative to non-OECD interest rates. However, with increasing relative demand for OECD goods, there is net upwards pressure on the OECD exchange rate.

To understand the long-run adjustment, it is emphasised that the change in the relative size of the regions involves no changes to any of the fundamental parameters which determine either technology or consumption preferences, nor is there any long-run change to growth in either region. Under these circumstances, the equilibrium conditions for each region -- in terms of interest rates and assets stocks -- are essentially unchanged from their initial positions, and it is only the exchange rate which adjusts to reflect the relative scarcity of OECD goods. Thus, the higher long-run level of the OECD exchange rate is sufficient to reduce the competitiveness of OECD exports to a degree which exactly eliminates the initial build-up in net foreign assets.

2. The two regions calibrated to be the OECD and non-OECD areas. For simplicity it is assumed that OECD net foreign assets are zero in 2000 .

3. Assuming an unchanged demographic structure and participation rates any given decline in the population translates into an equi-proportionate reduction in the labour force.

4. Since the two regions are calibrated differently - reflecting different technologies and different tastes - the effects on exchange rates and net foreign asset positions are close to, but not precisely, zero. 
Box 2. (contd.)

iii)

The negative impact of demographic changes on savings, concentrated in the OECD (row3)

This simulation features a fall in the OECD private savings propensity resulting from an ageing population. The decline in OECD savings, in the absence of any offsetting change in the non-OECD region, leads to relative scarcity of world savings in relation to investment and so to an increase in interest rates in both regions. Nevertheless, because this imbalance originates in the OECD region, excess consumption leads to OECD current account deficits and a consequent decline in OECD net foreign assets.

Long-run equilibrium is re-established when the increase in the OECD propensity to consume is counterbalanced by the negative effect of a reduction in wealth, which is mainly achieved through a rundown in OECD net foreign assets. At the new long-run equilibrium, net foreign assets as a proportion of GDP are significantly reduced and to maintain this position (to cover the interest payments on net external liabilities) the OECD needs to run a trade surplus, which in turn requires the OECD exchange rate to depreciate relative to it's initial level.

iv)

\section{The overall effect effects on interest rates, exchange rates and net foreign assets}

Although the reference scenario is not simply the sum of the three stylised simulations described above, the relative size and sign of the responses are helpful in understanding the path of interest rates, exchange rates and net foreign asset positions in the reference scenario as summarised below:

The overall response of world interest rates (column 1) depends on whether the effect of the slowdown in world growth dominates the effect of demographic pressures on savings. In the reference scenario the latter effect is (just) dominant and so there is a rise in world interest rates. In the "higher-savings" scenario the former effect is dominant and there is a sizeable fall in world interest rates. Regardless of which direction world interest rates move, rates of return in the non-OECD (even abstracting from sovereign risk premia), will be higher than those in the OECD, because of the faster growth rate in the former region.

Given both the increasing relative scarcity of OECD goods and lower interest rates in the OECD, the OECD exchange rate is likely to rise (column 2) and the magnitude of this effect is likely to dominate any demographic effects on savings -- a feature which is borne out in the reference scenario.

The initial response of OECD net foreign assets is ambiguous (column 3). Faster growth in the non-OECD region tends to lead to a build-up. The concentration of demographic effects on savings in the OECD will imply a run-down. However, to the extent that demographic pressures on OECD savings persist, it is likely that the latter effect will eventually dominate as it implies a more permanent rundown in net foreign assets. This is borne out in the reference scenario, where there is an initial build-up in net foreign assets in each of the three major OECD regions which is subsequently reversed -- with reversal occurring earliest in Japan, where demographic pressures on savings impact earliest. 
Box 2 (contd.)

Figure. Decomposition of key influences on interest rates, exchange rates and net foreign assets
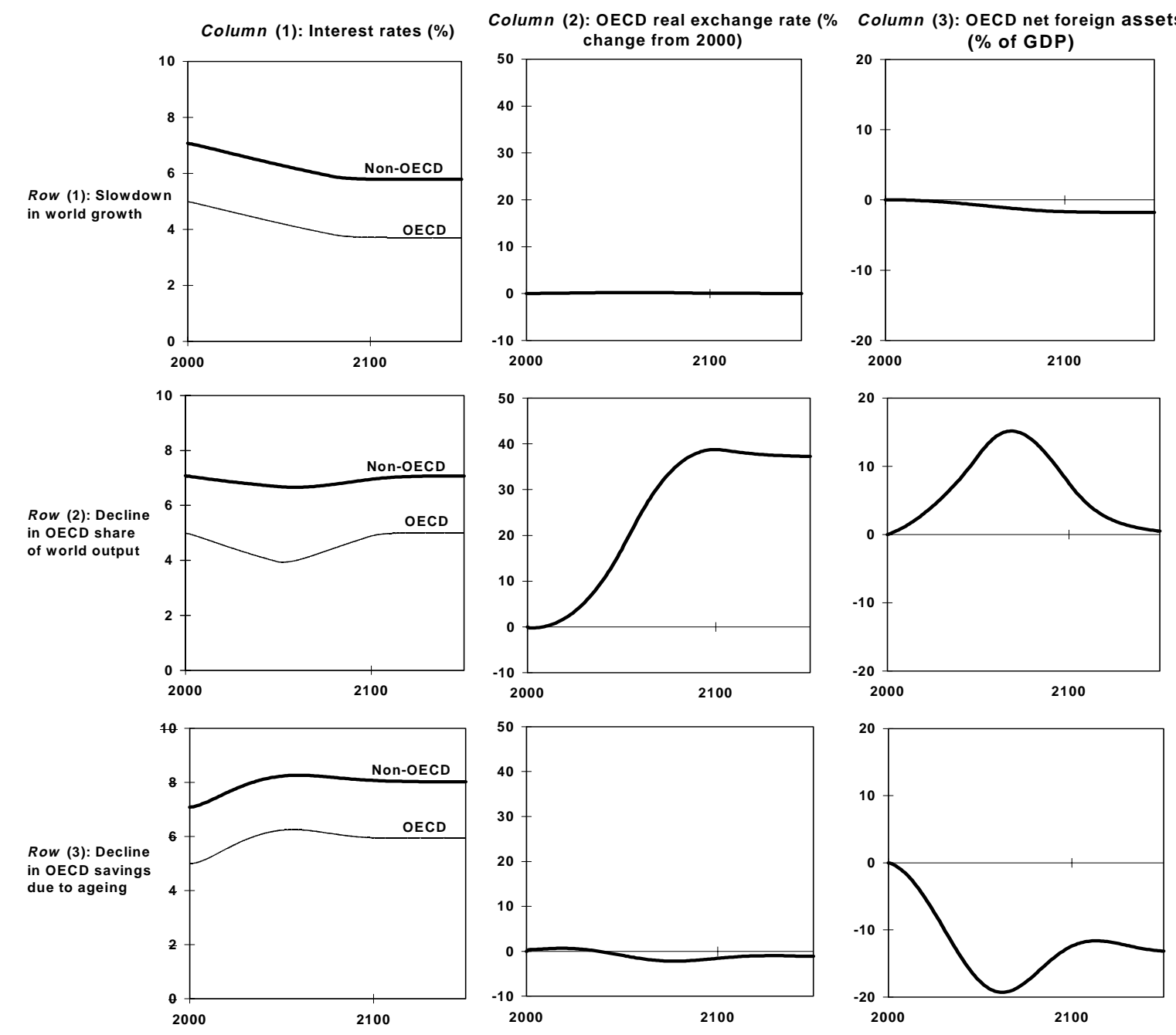


\section{Box 3. Are large swings in net external assets positions likely?}

The reference scenario suggests that there could be substantial swings in net foreign asset positions - to more than plus or minus 50 per cent of GDP - in the various regions. Over the next couple of decades OECD countries are expected to build up net external assets (to a greater or lesser degree dependent on demographic pressures on private and public savings) which will help to sustain living standards in subsequent decades. In the light of historical experience, the plausibility of such changes is considered below.

Prior to the First World War, the more advanced countries - particularly Great Britain , but also France and Germany - ran protracted current account surpluses to finance the savings deficit of "New World" countries like Canada, Argentina and Australia. In 1914, net foreign assets amounted to one and a half times GDP in Great Britain, 115 per cent of GDP in France and 40 per cent in Germany (Maddison, 1995). Liberal commercial policies and advances in transportation facilitated these large transfers of savings. However, they were also stimulated by a number of special factors: capital flows followed migration flows from capital source countries (while migration flows are in the reverse direction today); they were driven by the discovery and exploitation of new sources of raw materials; receiver countries had savings deficits which were partly attributable to demographic forces (while this is not the case for many of the most dynamic developing countries today).

Since then, current account imbalances have never reached the levels of the pre-1914 period ${ }^{2}$. Despite considerable growth in trade flows since the end of the Second World War, and huge increases in gross financial flows more recently, the net external asset positions of the major OECD have never exceeded 25 per cent of GDP during the last two decades in the major OECD countries (except in Canada) ${ }^{3}$. Moreover, notwithstanding very strong growth rates in the first half of the 1990s, net capital flows to developing countries remain small in relative terms, amounting to only 1 per cent of OECD GDP in $1995^{4}$. The reliance on domestic sources of savings to finance investment is further borne out by the high correlation between national saving and investment which has been found to hold over long periods of history.

1. Taylor and Williamson (1994) argue that demographic forces played a role in these transfers of saving, the young countries burdened with high dependency rates -- due to high fertility rates -- being unable to save as much as required to finance their large investment needs.

2. Japan's "high" current account surplus has averaged only 2-3 per cent of GDP over the past decade, compared to 5 per cent for the United Kingdom on average in the three decades preceding World War I.

3. See Table 53 of OECD Economic Outlook, No. 60.

4. After deduction of interest payment and FDI profit remittances, net resource transfers to developing countries represented only 0.6 per cent of OECD GDP.

5. See the seminal paper by Feldstein and Horioka (1980), and for example Tesar (1991) and Taylor (1996) for an analysis over long period.

6. In a regression on the 1990-1995 period, the World Bank (1997) finds that cyclical factors like the US interest rate play much less of a role in explaining private capital flows to developing countries when foreign direct investment is included in the dependent variable than when it is excluded. 
Box 3. (contd.)

On the other hand, the recent past may not be a reliable guide to future. There is some evidence that, although still strong, the correlation between saving and investment has weakened more recently (Feldstein and Bachetta, 1991, Obtsfeld, 1995). The recent increase in net capital flows, in particular to emerging countries, may reflect structural changes which could facilitate large changes in net external asset positions in future. Evidence for the increasing international integration of national economies is provided by the following:

- world trade growth has been very rapid since 1980, outpacing world output growth by a widening margin. Moreover, in the early 1990s, trade with non-OECD countries has been the most strongly growing component (see OECD, 1997);

- the surge in net capital flows to emerging economies has included major increases in foreign direct investment flows. This reflects a structural change in the firms production strategy, namely the breaking up of the production process in different countries according to their respective advantages, which is probably only in the early stages of its development. Empirical evidence also suggests that FDI flows are much less sensitive than other debt flows to changes in the international economic environment, such as changes in interest rates, and are, therefore, less prone to reversal'.

- the potential for portfolio flows from institutional investors to emerging economies to grow is still high. Despite the recent increase, the share of emerging markets in the portfolios of institutional investors remain small (only 2 per cent in the United States, where it has been growing most rapidly), well below their share in world market capitalisation (around 10 per cent). There is thus considerable scope for financial institutions to reap the benefits from higher expected returns and risk diversification by investing more in these markets. Relaxing the regulations restricting their foreign investment could possibly help in this matter (see Reisen, 1997).

- finally, the disruption of liberalisation policies is probably less likely than in the past. New technologies and new types of financial instruments make it more difficult for government to impose capital controls, on the one hand, and the liberalisation policies (for trade as well as for foreign investment) rest on a more solid institutional basis, involving multilateral links like the World Trade Organisation and the Multilateral Investment Agreement currently under negotiation. 


\section{BIBLIOGRAPHY}

ANDO, A. (1996), "Micro-Simulation Analysis of Aggregate Savings Behaviour in Japan", Report to the National Institute for Research Advancement, June.

ARMINGTON, P. (1969), “A theory of demand for products distinguished by place of production”, IMF Staff Papers, pp. 159-175, March.

AUERBACH, A. J., L. J. KOTLIKOFF, R. P. HAGEMANN and G. NICOLLETI (1989), "The Economic Dynamics of an Ageing Population: The Case of Four OECD Countries", OECD Economic Studies, No. 12, p. 97.

AUERBACH, A. J. and L. J. KOTLIKOFF. (1987), Dynamic Fiscal Analysis, Cambridge University Press, Cambridge, England.

BALL, L. and G. N. MANKIW (1995), "What do budget deficits do?", NBER Working Paper 5263, September.

BLANCHARD, O. J. (1985), "Debt, Deficits and Finite Horizons", Journal of Political Economy, Vol. 93, pp. 223-47.

BLOMMESTEIN, H. J. (1997), “Ageing-induced Capital flows to Emerging Markets do not solve OECD's basic problem", mimeo.

BLONDAL, S. and D. PILAT (1997), "The economic benefits of regulatory reform", OECD Economic Studies, No. 28, 1997/I.

BLONDAL, S. and S. SCARPETTA (1998), "The retirement decision", Economics Department Working Paper, OECD, forthcoming.

BLUNDELL, R. (1988), "Consumer Behaviour: Theory and Empirical Evidence - A Survey", The Economic Journal, Vol. 98, pp. 279-93.

BORSCH-SUPAN, A. (1996), "The Impact of Population Ageing on Savings, Investment and Growth in the OECD Area", in OECD (1996b) (ed.), Future Global Capital Shortages: Real Threat or Pure Fiction?, OECD, Paris.

BOS, E., E. MASSIAH and R. A. BULATAO (1994), "World Population Projections", World Bank, John Hopkins University.

BOSWORTH, B. and G. BURTLESS (1997), "Social Security Reform in a Global Context", paper prepared for a conference, "Social Security Reform: Links to Saving, Investment and Growth" sponsored by Federal Reserve Bank of Boston. 


\section{ECO/WKP(98)6}

BRYANT R. C. (1998), "The Government's Budget and Economic Prosperity”, Brookings Institute, forthcoming.

BRYANT, R. C. and L. ZHANG (1996a), "Intertemporal Fiscal Policy in Macroeconomic Models: Introduction and Major Alternatives", Brookings Discussion Paper No. 123, Brookings Institute.

BRYANT, R. C. and L. ZHANG (1996b), "Alternative Specifications of Inter-temporal Fiscal Policy in a Small Theoretical Model", Brookings Discussion Paper No. 124, The Brookings Institute.

CAMPBELL, J. Y. and N. G. MANKIW (1989), "Consumption, Income, and Interest Rates: Reinterpreting the Time Series Evidence”, NBER Macroeconomics Annual, p. 185-245.

CANARI, L. (1994), "Do demographic changes explain the decline in the saving rate of Italian households?", in Saving and the accumulation of wealth, Ando. A., L. Guiso and I. Visco (eds.), Cambridge University Press.

CARD, D. (1994), "Intertemporal Labour Supply: An Assessment", in Advances in econometrics: Sixth World Congress, Christopher A. Sims (Ed.), Cambridge University Press, Cambridge.

CASEY, B. (1997), "Incentives and Disincentives to Early and Late Retirement”, OECD.

CHAND, S. K., and A. JAEGER (1996), “Ageing Populations and Public Pension Schemes”, IMF Occasional paper 147, December.

CORDOBA, J. P. (1996), “The Impact of Demographic Development and Household Structure on Personal Savings", Ph.D. Dissertation, University of Pennsylvania.

CUTLER, D. M., J. M. POTERBA, L. M. SHEINER and L. H. SUMMERS (1990), “An Ageing Society: Opportunity or Challenge?", Brookings Papers on Economic Activity, No. 1.

EVANS, P. (1985), "Do Large Deficits Produce High Interest Rates?", American Economic Review, Vol. 75, pp. 63-87.

FARUQUEE, H., D. M. LAXTON and S. SYMANSKY (1996), "Government Debt, Life-Cycle Income and Liquidity Constraints: Beyond Ricardian Equivalence", IMF Working Paper, December.

FELDSTEIN, M. and P. BACHETTA (1991), "National Saving and International Investment", in Bernheim and Shoven (eds), National Saving and Economic Performance, The University of Chicago Press, Chicago.

FELDSTEIN, M. and C. HORIOKA (1980), "Domestic Saving and International Capital Flows", Economic Journal 90, pp. 314-29, June.

FELDSTEIN, M., (1980)“International Differences in Social Security and Saving," Journal of Public Economics, Vol. 14, pp. 225-44, October.

FLAVIN, M. A., (1993), "Excess Smoothness of Consumption: Identification and Interpretation", Review of Economic Studies, Vol. 60, pp. 651-66.

FORD, R. and D. M. LAXTON, (1995), “World Public Debt and Real Interest Rates”, IMF Working Paper. 
FOUGERE, M. and M. MERETTE (1997), "Population Ageing and the Current Account in Selected OECD Countries", Department of Finance, Canada, mimeo, December.

GRAHAM, J. W. (1987), "International Differences in Saving Rates and the Life Cycle of Hypothesis, "European Economic Review, Vol. 31, pp. 1509-29.

GRUBER, J. and D. WISE (1997), "Social Security Programs and Retirement Around the World", NBER Working Paper No. 6134, August.

HAYASHI, F. (1985), "The Effects of Liquidity Constraints on Consumption: A Cross-Sectional Analysis", Quarterly Journal of Economics, Vol. 100, pp. 183-206.

HELBLING, T. and R. WESTCOTT (1995), "The Global Real Interest Rate", Staff Studies for the World Economic Outlook, IMF, September.

HORIOKA, C. Y. (1986), "Why is Japan's Private Saving Rate So High?", unpublished; International Monetary Fund, Washington, June.

HORIOKA, C. Y. (1991), “The Determinants of Japan's Private Saving Rate: The Impact of the Age Structure of the Population and Other Factors," Economic Studies Quarterly, Vol. 42, pp. 237-53, September.

HVIDING, K., R. KOHL and P. O'BRIEN (1998), "The macroeconomics of ageing, pensions and savings", Economics Department Working Paper, OECD, forthcoming.

JAPELLI, T. and M. PAGANO (1990), "Consumption and Capital Market Imperfections: An International Comparison", American Economic Review, Vol. 79, pp. 1088-105.

KOSKELA, E. and M. VIREN (1989), "International Differences in Saving Rates and the Life Cycle Hypothesis: A Comment,' European Economic Review, Vol. 33, pp. 1489-98, September.

LEIBFRITZ, W., D. ROSEVEARE, D. FORE and E. WURZEL (1996), "Ageing Populations, Pension Systems and Government Budgets: How Do They Affect Saving?" in OECD (1996b) (ed.), Future Global Capital Shortages: Real Threat or Pure Fiction?, OECD, Paris.

MADDISON, A. (1995), "Monitoring the World Economy: 1820-1992", OECD Development Centre, OECD, Paris.

MACKELLAR, L. and H. REISEN (1997), “A Simulation Model of Global Pension Fund Investment”, OECD, September.

MASSON, P. R., T. BAYOUMI and H. SAMIEI (1995), "International Evidence on the Determinants of Private Savings", IMF Working Paper, May.

MASSON, P. R., S. A. SYMANSKY and G. MEREDITH (1990), "MULTIMOD Mark II: A Revised and Extended Model", Occasional Paper 71, International Monetary Fund, Washington, D.C.

MASSON, P. R. and R. TRYON (1990), "Macroeconomic Effects of Projected Population Ageing in Industrial Countries", IMF Working Paper, January.

MEREDITH, G. (1995), "Demographic Change and Household Saving in Japan", in Saving Behavior and the Asset Price "Bubble" in Japan, U. Baumgartner and G. Meredith Eds, IMF Occasional Paper No. 124. 


\section{ECO/WKP(98)6}

MILES, D. (1997), "Modelling the Impact of Demographic Change Upon the Economy", CEPR Discussion paper No. 1762.

MODIGLIANI, F. (1970), "The Life-Cycle Hypothesis of Saving and Intercountry Differences in the Saving Ratio," in Induction, Growth and Trade, W. A. Eltis, M. F. Scott and J. N. Wolfe (eds.), Clarendon, pp. 197-225, Oxford.

MODIGLIANI, F. and A. STERLING, "Determinants of Private Savings with Special Reference to the Role of Social Security-Cross-Country Tests," in The Determinants of National Saving and Wealth, F. Modigliani and R. Hemming (eds.), pp. 24-55, St. Martin's, New York.

OBTSFELD, M. (1995), "International Capital Mobility in the 1990s", in P. B. Kenen (ed.), Understanding Interdependence, Princeton University Press, Princeton.

OECD (1990), OECD Economic Survey: Japan (1989/90), Paris.

OECD (1996a), “Ageing in OECD Countries, A Critical Policy Challenge”, OECD, Paris.

OECD (1996b), “Future Global Capital Shortages: Real Threat or Pure Fiction?’, OECD, Paris.

OECD (1997), "The World in 2020: Towards A New Global Age", OECD, Paris.

POTERBA, J. ed. (1994), “International Comparisons of Household Savings”, University of Chicago Press.

REISEN, H. (1997), "Can the Ageing OECD Escape Demography through Capital Flows to the Emerging Markets?", OECD.

RICHARDSON, P. W. (1997), "Globalisation and Linkages: Macro-Structural Challenges and Opportunities", Economics Department Working Paper No. 181, OECD.

ROSEVEARE, D., W. LEIBFRITZ, D. FORE and E. WURZEL (1996), "Ageing Populations, Pension Systems and Government Budgets: Simulations for 20 OECD Countries.", Economics Department Working Paper No. 168, OECD.

SEATER, J. J. (1993), "Ricardian Equivalence", Journal of Economic Literature, Vol. XXXI, No. 1, pp. 142-93.

SHIBUYA, H. (1987), "Japan's Household Saving Rate: An Application of the Life Cycle Hypothesis," IMF Working Paper 87/15, March, Washington.

STURM, P. H. (1983), "Determinants of Saving: Theory and Evidence", OECD Economic Studies, No. 1, p. 147-96.

TAYLOR, A. M. (1996), "International Capital Mobility in History: The Saving-Investment Relationship, NBER Working Paper No. 5743, September.

TAYLOR, A. M. and J. G. WILLIAMSON (1994), "Capital Flows to the New World as an Intergenerational Transfer”, Journal of Political Economy, Vol. 102, No. 2.

TESAR, L. L. (1991) "Savings, Investment and International Capital Flows", Journal of International Economics, Vol. 31, No. 112, August. 
UNITED NATIONS (1996), "World Population Prospects 1950-2050 (the 1996 revision), data base.

YASHIRO, N. and T. OSHIO (1997), "Macroeconomic and Fiscal Imperatives of the Aging population in Japan”, Institute of International Relations, July.

WORLD BANK (1997), "Private Capital Flows to Developing Countries: The Road to Financial Integration", Oxford University Press. 


\section{ECO/WKP(98)6}

Table 1. Living standards and real interest rates in the reference case and alternative scenarios

\begin{tabular}{|c|c|c|c|c|c|c|c|c|c|}
\hline & \multicolumn{3}{|c|}{ United States } & \multicolumn{3}{|c|}{ Japan } & \multicolumn{3}{|c|}{ European Union } \\
\hline & \multicolumn{2}{|c|}{ Living standards ${ }^{1}$} & \multirow{2}{*}{$\begin{array}{c}\text { Real } \\
\text { interest } \\
\text { rate by } \\
2050\end{array}$} & \multicolumn{2}{|c|}{ Living standards ${ }^{1}$} & \multirow{2}{*}{$\begin{array}{c}\text { Real } \\
\text { interest } \\
\text { rate by } \\
2050 \\
\end{array}$} & \multicolumn{2}{|c|}{ Living standards ${ }^{1}$} & \multirow{2}{*}{$\begin{array}{c}\text { Real } \\
\text { interest } \\
\text { rate by } \\
2050\end{array}$} \\
\hline & $\begin{array}{c}\text { Average } \\
\text { growth } \\
2000-2050\end{array}$ & $\begin{array}{c}\text { Level } \\
\text { by } 2050 \\
1995=100\end{array}$ & & $\begin{array}{c}\text { Average } \\
\text { growth } \\
2000-2050\end{array}$ & $\begin{array}{c}\text { Level } \\
\text { by } 2050 \\
1995=100\end{array}$ & & $\begin{array}{c}\text { Average } \\
\text { growth } \\
2000-2050\end{array}$ & $\begin{array}{c}\text { Level } \\
\text { by } 2050 \\
1995=100\end{array}$ & \\
\hline Reference-case scenario & 1.1 & 176 & 5.5 & 1.1 & 176 & 5.4 & 1.3 & 195 & 4.9 \\
\hline Higher-savings scenario & 1.3 & 194 & 2.8 & 1.5 & 207 & 2.1 & 1.6 & 219 & 1.8 \\
\hline Combined-reforms scenario & 1.4 & 202 & 4.2 & 1.7 & 227 & 3.8 & 2.0 & 264 & 3.5 \\
\hline \multicolumn{10}{|c|}{ Differences from the reference case } \\
\hline Alternative scenarios ${ }^{2}$ & $\begin{array}{c}\text { Per cent } \\
\text { per annum }\end{array}$ & Per cent & $\begin{array}{l}\text { Interest } \\
\text { points }\end{array}$ & $\begin{array}{c}\text { Per cent } \\
\text { per annum }\end{array}$ & Per cent & $\begin{array}{l}\text { Interest } \\
\text { points }\end{array}$ & $\begin{array}{c}\text { Per cent } \\
\text { per annum }\end{array}$ & Per cent & $\begin{array}{c}\text { Interest } \\
\text { points }\end{array}$ \\
\hline 1. Debt stabilisation-OECD wide & 0.1 & 3.5 & -1.0 & 0.1 & 6.8 & -1.2 & 0.1 & 5.1 & -1.1 \\
\hline 2. Later retirement with debt reduction & 0.2 & 11.5 & -1.2 & 0.3 & 18.6 & -1.5 & 0.3 & 16.2 & -1.4 \\
\hline 3. Higher labour force participation & 0.1 & 7.3 & 0.1 & $0.0^{3}$ & 0.7 & $0.0^{3}$ & 0.4 & 20.8 & $0.0^{3}$ \\
\hline 4. Higher total factor production level & $0.0^{3}$ & 2.0 & $0.0^{3}$ & 0.2 & 10.0 & $0.0^{3}$ & 0.1 & 7.3 & $0.0^{3}$ \\
\hline 6. Higher-savings scenario & 0.2 & 10.0 & -2.7 & 0.3 & 17.9 & -3.3 & 0.2 & 12.6 & 3.1 \\
\hline
\end{tabular}

1. Living standards, measured in terms of GNP per capita, adjusted for the terms of trade.

2. Alternative scenarios are as described in section 3 of the main paper.

3. Zero entries indicate differences at the second decimal place only.

4. The combined reforms scenario includes separate elements from scenarios 2, 3 and 4 .

Source: Secretariat's estimates. 
Table 2. Summary of estimated effects of the dependency ratio on the private saving rate ${ }^{1}$

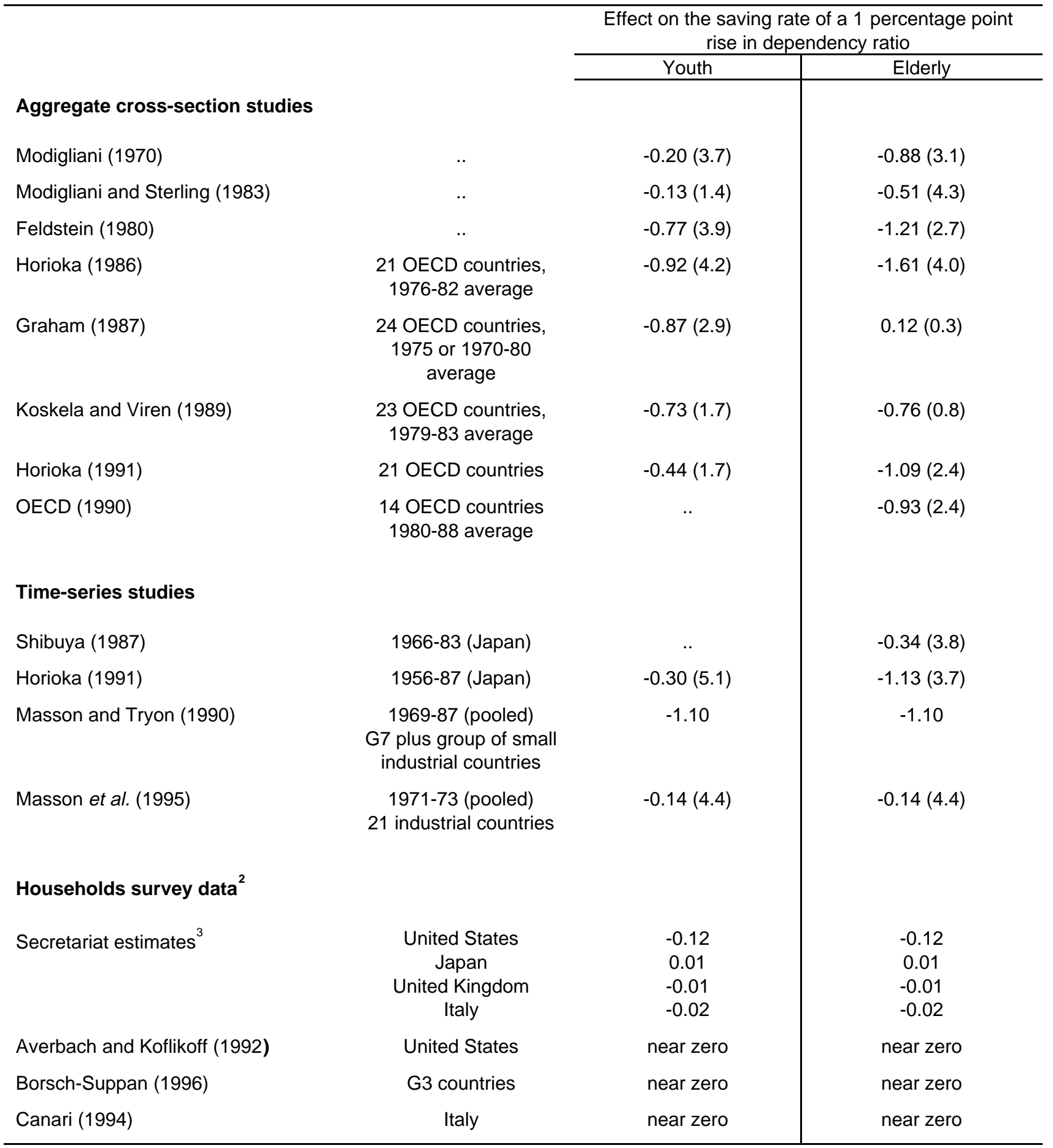

1. This table is an updated version of that appearing in Meredith (1995).

2. Estimates reported under this heading assume that savings rates per age obtained from survey data remain unchanged through time. Future variations in the aggregate savings rate coming from changes in projected population structures are then calculated for a period going to 2050.

3. The survey data on savings rate per cohort used for the Secretariat estimates were taken from Poterba (1994) and Borsch-Suppan (1996). 
Table 3. Contributions to growth in the reference scenario (per cent per annum)

\begin{tabular}{lc|cccc}
\hline & $\begin{array}{c}\text { Average } \\
\text { growth } \\
\text { in potential } \\
\text { output }\end{array}$ & \multicolumn{4}{|c}{ Contributions from: } \\
\cline { 2 - 6 } & & $\begin{array}{c}\text { Working-age } \\
\text { population }\end{array}$ & $\begin{array}{c}\text { Participation } \\
\text { rate }\end{array}$ & $\begin{array}{c}\text { Labour } \\
\text { efficiency }\end{array}$ & $\begin{array}{c}\text { Capital } \\
\text { intensity }\end{array}$ \\
\cline { 2 - 6 } $2000^{1}$ & & & & \\
United States & 2.5 & 1.1 & 0.2 & 1.2 & - \\
Japan & 1.9 & -0.3 & 0.9 & 1.4 & - \\
European Union & 2.3 & 0.1 & 0.2 & 2.0 & - \\
& & & & & \\
2000-2025 & 1.6 & 0.4 & 0.0 & 1.3 & 0.0 \\
United States & 0.9 & -0.7 & 0.2 & 1.4 & 0.0 \\
Japan & 1.2 & -0.4 & -0.1 & 1.7 & 0.0 \\
European Union & & & & & -0.1 \\
2025-2050 & & & & & -0.1 \\
United States & 1.4 & 0.1 & 0.0 & 1.4 & -0.1 \\
Japan & 0.6 & -0.9 & 0.1 & 1.4 & 1.4 \\
European Union & 0.5 & -0.9 & 0.0 & & \\
\hline
\end{tabular}

1. Estimates for 2000 are based on an assumed growth equilibrium path i.e. with stable capital intensity. 
Table 4. Effects of saving and investment pressures on interest rates, exchange rates and net foreign assets

\begin{tabular}{|c|c|c|c|c|c|}
\hline & & Ex-ante savings \& investment & Interest rates & Exchange rates & Net foreign asset positions \\
\hline 1) & $\begin{array}{l}\text { Generalised permanent } \\
\text { slowdown in world } \\
\text { output growth }\end{array}$ & $\begin{array}{l}\text { Net reduction in ex-ante world } \\
\text { investment (over savings). }\end{array}$ & Fall in world real interest rates. & No implications. & No implications. \\
\hline 2) & $\begin{array}{l}\text { Decline in weight of } \\
\text { OECD in world output }\end{array}$ & $\begin{array}{l}\text { Initial improvement in OECD } \\
\text { savings relative to investment } \\
\text { (i.e. improved OECD current } \\
\text { position). }\end{array}$ & $\begin{array}{l}\text { Higher in non-OECD that } \\
\text { OECD (reflecting faster } \\
\text { growth). }\end{array}$ & $\begin{array}{l}\text { Appreciation of OECD } \\
\text { exchange rates. }\end{array}$ & $\begin{array}{l}\text { Initial build-up in OECD net } \\
\text { foreign assets, but } \\
\text { subsequently depleted. }\end{array}$ \\
\hline 3) & $\begin{array}{l}\text { Ageing effects on savings, } \\
\text { given earlier ageing in } \\
\text { OECD }\end{array}$ & $\begin{array}{l}\text { Ex-ante reduction in OECD } \\
\text { savings, but increase in non- } \\
\text { OECD savings. Overall effect } \\
\text { on world ex-ante savings } \\
\text { increasingly negative over } \\
\text { time, especially once non- } \\
\text { OECD populations begin to } \\
\text { age. }\end{array}$ & $\begin{array}{l}\text { Increase in OECD interest } \\
\text { rates relative to non-OECD. } \\
\text { Overall effect on level of } \\
\text { (average) world interest rates } \\
\text { increasingly positive. }\end{array}$ & $\begin{array}{l}\text { Depreciation of OECD } \\
\text { exchange rates. }\end{array}$ & $\begin{array}{l}\text { Permanent fall in OECD net } \\
\text { foreign asset position. }\end{array}$ \\
\hline
\end{tabular}

1. Assumes an equal reduction in output growth in all regions. 
Table 5. Living standards in the reference scenario ${ }^{1}$

\begin{tabular}{|c|c|c|c|c|c|c|c|c|}
\hline & $1970-1980$ & $1980-1990$ & $1990-2000$ & $2000-2010$ & $2010-2020$ & $2020-2030$ & $2030-2040$ & $2040-2050$ \\
\hline \multicolumn{9}{|c|}{ Annual Growth rates (per cent) } \\
\hline United States & 1.6 & 1.7 & 1.7 & 1.4 & 1.0 & 1.0 & 1.2 & 1.2 \\
\hline Japan & 2.8 & 3.7 & 1.5 & 1.3 & 1.3 & 1.4 & 0.8 & 0.9 \\
\hline \multirow[t]{2}{*}{ European Union } & 2.2 & 2.2 & 1.7 & 1.9 & 1.5 & 1.1 & 1.1 & 1.1 \\
\hline & & & & 2010 & 2020 & 2030 & 2040 & 2050 \\
\hline \multicolumn{9}{|c|}{ Levels (Indices, $2000=100)$} \\
\hline United States & & & & 114.7 & 126.7 & 139.9 & 157.4 & 176.4 \\
\hline Japan & & & & 113.7 & 129.2 & 148.8 & 161.1 & 175.5 \\
\hline European Union & & & & 121.2 & 140.9 & 157.2 & 175.0 & 194.9 \\
\hline \multicolumn{9}{|c|}{$\begin{array}{l}\text { Potential losses in level terms relative to } \\
\text { recent historical trends (per cent) }\end{array}$} \\
\hline United States & & & & -3.1 & -9.6 & -15.6 & -19.8 & -24.1 \\
\hline Japan & & & & -6.7 & -13.0 & -17.9 & -27.0 & -34.8 \\
\hline European Union & & & & -0.7 & -5.3 & -13.2 & -20.7 & -27.6 \\
\hline
\end{tabular}

1. Living standards measured as GNP per capita adjusted for the terms of trade.

2. Estimated as the difference between levels in the reference scenario and levels extrapolated on the basis

of recent historical trends ( $1^{3 / 4}$ percent for the United States and 2 per cent for Japan and the European Union). 
Table 6. Contributions to growth in livings standards : comparisons of reference and higher-savings scenarios ${ }^{1}$

Difference from reference case in percent

\begin{tabular}{|c|c|c|c|c|c|c|}
\hline & 2010 & 2020 & 2030 & 2040 & 2050 & 2100 \\
\hline \multicolumn{7}{|l|}{ United States } \\
\hline Per capita consumption level ${ }^{2}$ & -1.2 & -0.7 & 1.3 & 4.5 & 6.5 & 6.2 \\
\hline $\begin{array}{l}\text { Per capita GNP level }{ }^{3} \\
\text { of which. }\end{array}$ & 1.2 & 3.7 & 6.5 & 8.8 & 10.0 & 8.3 \\
\hline $\begin{array}{l}\text { Or which : } \\
\text { Capital deepening }\end{array}$ & 1.2 & 3.9 & \multicolumn{4}{|c|}{ of which : } \\
\hline Investment income & 0.0 & 0.0 & 0.1 & 0.7 & 1.6 & 1.8 \\
\hline Terms of trade & 0.0 & -0.2 & -0.3 & -0.2 & -0.1 & -0.0 \\
\hline \multicolumn{7}{|l|}{ Japan } \\
\hline Per capita consumption level ${ }^{2}$ & -5.0 & -3.5 & 1.9 & 6.4 & 12.3 & 9.8 \\
\hline Per capita GNP level ${ }^{3}$ & 0.9 & 5.5 & 9.8 & 14.0 & 17.9 & 9.6 \\
\hline \multicolumn{7}{|l|}{ of which: } \\
\hline Capital deepening & 0.9 & 5.0 & 8.2 & 10.3 & 11.4 & 7.1 \\
\hline Investment income & 0.7 & 1.7 & 2.5 & 3.7 & 5.3 & 0.7 \\
\hline Terms of trade & -0.7 & -1.2 & -1.0 & -0.0 & 1.2 & 1.8 \\
\hline \multicolumn{7}{|l|}{ European Union } \\
\hline Per capita consumption level ${ }^{2}$ & -2.9 & -2.1 & -0.3 & 2.9 & 7.0 & 7.1 \\
\hline Per capita GNP level ${ }^{3}$ & 1.2 & 4.4 & 7.0 & 9.6 & 12.6 & 7.4 \\
\hline \multicolumn{7}{|l|}{ of which : } \\
\hline Capital deepening & 1.2 & 4.2 & 7.2 & 9.8 & 11.1 & 5.1 \\
\hline Investment income & 0.3 & 0.7 & 0.7 & 1.1 & 2.5 & 1.7 \\
\hline Terms of trade & -0.3 & -0.5 & -0.9 & -1.3 & -0.9 & 0.5 \\
\hline \multicolumn{7}{|l|}{ Other fast ageing countries } \\
\hline Per capita consumption level ${ }^{2}$ & -0.3 & 2.2 & 5.0 & 6.5 & 6.6 & 4.2 \\
\hline Per capita GNP level ${ }^{3}$ & 1.6 & 4.8 & 7.5 & 8.8 & 8.5 & 6.5 \\
\hline \multicolumn{7}{|l|}{ of which : } \\
\hline Capital deepening & 1.7 & 4.8 & 7.4 & 8.9 & 9.4 & 7.3 \\
\hline Investment income & -0.1 & -0.2 & -0.2 & -0.4 & -1.1 & -0.7 \\
\hline Terms of trade & 0.1 & 0.2 & 0.3 & 0.3 & 0.2 & -0.1 \\
\hline \multicolumn{7}{|l|}{ Slow ageing countries } \\
\hline Per capita consumption level ${ }^{2}$ & 0.5 & 2.9 & 4.7 & 5.4 & 5.3 & 4.0 \\
\hline Per capita GNP Ievel ${ }^{3}$ & 2.0 & 4.7 & 6.7 & 7.4 & 7.4 & 6.6 \\
\hline \multicolumn{7}{|l|}{ of which: } \\
\hline Capital deepening & 1.9 & 4.7 & 6.9 & 8.3 & 9.0 & 7.3 \\
\hline Investment income & -0.2 & -0.4 & -0.5 & -1.0 & -1.9 & -0.9 \\
\hline Terms of trade & 0.3 & 0.4 & 0.3 & 0.1 & 0.2 & 0.1 \\
\hline
\end{tabular}

1. The higher-saving scenario abstracts from the direct effects of higher dependency rates on private and public savings in the main OECD regions.

2. Measured as total private and public consumption per capita.

3. Measured as GNP per capita adjusted for terms of trade effects (see Technical Annex for details of the calculation) 
Table 7. Effects of an OECD-wide debt stabilisation ${ }^{1}$

Difference from reference case in percent

$\begin{array}{llllll}2010 & 2020 & 2030 & 2040 & 2050 & 2100\end{array}$

\section{United States}

Per capita consumption level ${ }^{2}$ Per capita GNP level ${ }^{3}$ of which :

Capital deepening

Investment income

Terms of trade

$\begin{array}{rrrrrr}-0.2 & -0.7 & -0.3 & 1.2 & 2.0 & 1.7 \\ 0.1 & 0.8 & 2.1 & 3.2 & 3.5 & 2.7 \\ & & & & & \\ 0.1 & 0.8 & 2.0 & 2.8 & 2.9 & 1.7 \\ -0.0 & 0.1 & 0.3 & 0.5 & 0.6 & 1.0 \\ -0.0 & -0.1 & -0.2 & -0.1 & -0.0 & 0.0\end{array}$

\section{Japan}

Per capita consumption level ${ }^{2}$

Per capita GNP level ${ }^{3}$

$\begin{array}{rrrrrr}-1.7 & -1.7 & -0.0 & 0.6 & 2.3 & 4.9 \\ 0.1 & 1.8 & 3.6 & 5.1 & 6.8 & 4.7 \\ & & & & & \\ 0.0 & 1.3 & 2.3 & 3.1 & 4.0 & 1.5 \\ 0.3 & 0.9 & 1.5 & 2.1 & 2.8 & 2.2 \\ -0.2 & -0.3 & -0.2 & -0.1 & 0.1 & 1.0\end{array}$

\section{European Union}

which:

Investment income

Terms of trade

$-0.2$

$-0.1$

Per capita consumption level ${ }^{2}$ Per capita GNP level ${ }^{3}$

$\begin{array}{rrrrrr}-0.3 & -0.7 & -0.9 & -0.2 & 1.7 & 3.4 \\ 0.4 & 0.9 & 2.1 & 3.7 & 5.1 & 3.0 \\ & & & & & \\ 0.3 & 0.8 & 1.8 & 2.9 & 3.6 & 1.6 \\ 0.0 & 0.2 & 0.5 & 1.1 & 1.7 & 1.1 \\ 0.1 & -0.1 & -0.3 & -0.3 & -0.2 & 0.3\end{array}$

\section{Other fast ageing countries}

Capital deepening
Investment income

Terms of trade

Per capita consumption level ${ }^{2}$ Per capita GNP level ${ }^{3}$

$\begin{array}{rrrrrr}-0.1 & 0.6 & 1.5 & 2.0 & 2.0 & 0.3 \\ 0.3 & 1.1 & 1.9 & 2.2 & 2.1 & 1.0 \\ 0.3 & 1.2 & 2.2 & 2.9 & 3.2 & 2.0 \\ -0.0 & -0.2 & -0.5 & -0.9 & -1.2 & -1.0 \\ 0.0 & 0.1 & 0.2 & 0.2 & 0.1 & -0.0\end{array}$

\section{Slow ageing countries}

Capital deepening

Investment income

Terms of trade

Per capita consumption level ${ }^{2}$

Per capita GNP level ${ }^{3}$

$\begin{array}{rr}0.1 & 0.8 \\ 0.4 & 1.3 \\ & \\ 0.5 & 1.3 \\ -0.1 & -0.2 \\ 0.0 & 0.2\end{array}$

0.8

1.5
1.8
2.1
-0.5
0.2

1.9

1.8

$-0.2$

of which :

Capital deepening

Investment income

Terms of trade

1.3
-0.2
0.2

2.1
-0.5
0.2

2.7

2.7
-0.9

1.8

1. Government debt to GDP ratios are assumed to remain constant in the main OECD regions at their estimated level at the beginning of the projection period, with public expenditures increasing by only a $1 / 4$ of their increase in the reference scenario.

2. Measured as total private and public consumption per capita.

3. Measured as GNP per capita adjusted for terms of trade effects (see Technical Annex for details of the calculation) 
Table 8. Effects of debt stabilisation in Japan only ${ }^{1}$

Difference from reference case in percent

\begin{tabular}{|c|c|c|c|c|c|c|}
\hline & 2010 & 2020 & 2030 & 2040 & 2050 & 2100 \\
\hline \multicolumn{7}{|l|}{ United States } \\
\hline Per capita consumption level ${ }^{2}$ & -0.0 & 0.2 & 0.4 & 0.5 & 0.5 & 0.1 \\
\hline $\begin{array}{l}\text { Per capita GNP level } \\
\text { of which : }\end{array}$ & 0.1 & 0.3 & 0.4 & 0.5 & 0.4 & 0.2 \\
\hline Capital deepening & 0.1 & 0.4 & 0.5 & 0.6 & 0.7 & 0.5 \\
\hline Investment income & 0.0 & -0.1 & -0.1 & -0.2 & -0.3 & -0.3 \\
\hline Terms of trade & 0.0 & 0.1 & 0.1 & 0.1 & 0.1 & -0.1 \\
\hline \multicolumn{7}{|l|}{ Japan } \\
\hline Per capita consumption level ${ }^{2}$ & -1.4 & -2.4 & -1.3 & -1.1 & 0.1 & \\
\hline $\begin{array}{l}\text { Per capita GNP level } \\
\text { of which: }\end{array}$ & 0.1 & 0.4 & 1.9 & 3.2 & 4.5 & 2.3 \\
\hline Capital deepening & -0.1 & 0.0 & 0.6 & 0.9 & 1.3 & -1 \\
\hline Investment income & $\begin{array}{r}-0.1 \\
0.2\end{array}$ & 1.0 & 1.8 & 2.7 & 3.8 & \\
\hline Terms of trade & 0.0 & -0.6 & -0.4 & -0.5 & -0.5 & 0.6 \\
\hline \multicolumn{7}{|l|}{ European Union } \\
\hline Per capita consumption level ${ }^{2}$ & -0.0 & 0.2 & 0.4 & 0.4 & 0.5 & \\
\hline Per capita GNP level ${ }^{3}$ & 0.1 & 0.4 & 0.5 & 0.5 & 0.5 & 0.2 \\
\hline of which : & & & & & & \\
\hline Capital deepening & 0.1 & 0.4 & 0.5 & 0.6 & 0.7 & $\begin{array}{r}0.5 \\
-0.3\end{array}$ \\
\hline Investment income & -0.0 & -0.1 & -0.1 & -0.2 & -0.3 & -0.3 \\
\hline Terms of trade & -0.0 & 0.1 & 0.0 & 0.0 & 0.1 & -0.1 \\
\hline \multicolumn{7}{|l|}{ Other fast ageing countries } \\
\hline Per capita consumption level ${ }^{2}$ & 0.0 & 0.2 & 0.4 & 0.5 & 0.5 & \\
\hline Per capita GNP level ${ }^{3}$ & 0.1 & 0.3 & 0.4 & 0.5 & 0.5 & 0.2 \\
\hline of which : & & & & & & \\
\hline Capital deepening & 0.1 & 0.4 & 0.6 & 0.7 & 0.8 & $\begin{array}{r}0.5 \\
-0.3\end{array}$ \\
\hline Investment income & -0.0 & -0.1 & -0.2 & -0.2 & -0.3 & -0.3 \\
\hline Terms of trade & 0.0 & 0.0 & 0.0 & 0.0 & 0.0 & -0.0 \\
\hline \multicolumn{7}{|l|}{ Slow ageing countries } \\
\hline Per capita consumption level ${ }^{2}$ & 0.1 & 0.3 & 0.4 & 0.4 & 0.5 & 0.2 \\
\hline Per capita GNP level ${ }^{3}$ & 0.1 & 0.4 & 0.4 & 0.5 & 0.5 & 0.3 \\
\hline of which : & & & & & & \\
\hline Capital deepening & 0.1 & 0.4 & 0.6 & 0.7 & 0.8 & $\begin{array}{r}0.5 \\
-02\end{array}$ \\
\hline Investment income & -0.0 & -0.1 & -0.1 & -0.2 & -0.3 & -0.2 \\
\hline Terms of trade & -0.0 & 0.1 & 0.0 & 0.0 & 0.0 & -0.0 \\
\hline
\end{tabular}

1. Government debt to GDP ratios and public expenditures as a proportion of GDP are assumed to remain constant at their estimated level at the beginning of the projection period in Japan only.

2. Measured as total private and public consumption per capita.

3. Measured as GNP per capita adjusted for terms of trade effects (see Technical Annex for details of the calculation) 
ECO/WKP(98)6

Table 9. Assumptions on retirement age

\begin{tabular}{|c|c|c|}
\hline Country & Reference scenario & Later retirement \\
\hline United States & $\begin{array}{l}\text { Increased from } 65 \text { to } 66 \text { between } 2000 \text { and } 2005 \\
\text { and to } 57 \text { in } 2020 .\end{array}$ & $\begin{array}{l}\text { Same as in the baseline until } 2005 \text {; increased } \\
\text { then to } 70 \text { in } 2015 \text {, at a speed of } 0.5 \text { year per } \\
\text { year. }\end{array}$ \\
\hline Japan & $\begin{array}{l}\text { Increased from } 60 \text { to } 62.5 \text { in } 2005 \text {, to } 64 \text { in } 2010 \text {, } \\
\text { and to } 65 \text { in } 2015 \text { for men; for women, increased } \\
\text { from } 60 \text { to } 62.5 \text { between } 2005 \text { and } 2010 \text {, to } 64 \text { in } \\
2015 \text { and } 65 \text { in } 2020 \text {. }\end{array}$ & $\begin{array}{l}\text { Same as in the baseline for men and women } \\
\text { until 2005; increased gradually (at a speed of } \\
0.5 \text { years per year) to } 70 \text { in } 2020 \text { for men; for } \\
\text { women, same as in the baseline until } 2010 \text {, } \\
\text { increased then gradually at the same speed as } \\
\text { for men to } 70 \text { in } 2025 \text {. }\end{array}$ \\
\hline France & Constant at 60. & $\begin{array}{l}\text { Increased gradually from } 60 \text { in } 2025 \text { to } 65 \text { in } \\
2015 .\end{array}$ \\
\hline Germany & $\begin{array}{l}\text { For women, increased from } 60 \text { in } 2000 \text { to } 61 \text { in } \\
2005,62 \text { in } 2010,63 \text { in } 2015 \text { and } 65 \text { in } 2020 \text {; for } \\
\text { men, increased from } 63 \text { in } 2000 \text { to } 64 \text { in } 2005 \text {, } \\
\text { and } 65 \text { in } 2010 .\end{array}$ & $\begin{array}{l}\text { Same as in the baseline until } 2005 \text { for women } \\
\text { and men; increased thereafter for both half a } \\
\text { year each year to } 70 \text { (reached in } 2025 \text { for } \\
\text { women and } 2020 \text { for men). }\end{array}$ \\
\hline United Kingdom & $\begin{array}{l}\text { For women, increased from the current level of } 60 \\
\text { to } 62.5 \text { between } 2010 \text { and } 2015 \text { and to } 65 \text { in } 2020 \text {; } \\
65 \text { for men. }\end{array}$ & No such scenario. \\
\hline Italy & $\begin{array}{l}\text { Currently } 53 \text { on average, increased to } 55 \text { between } \\
2005 \text { and } 2010,57 \text { in } 2015 \text { and then by one year } \\
\text { each years, up to } 63 \text { in } 2045 \text {. }\end{array}$ & $\begin{array}{l}\text { Same as in the baseline until 2015; increased } \\
\text { gradually by half a year per year up to } 65 \text { in } \\
2030 \text { thereafter. }\end{array}$ \\
\hline
\end{tabular}


ECO/WKP(98)6

Table 10. Effects of debt stabilisation with an increase in the retirement age ${ }^{1}$ Difference from reference case in percent

\begin{tabular}{|c|c|c|c|c|c|c|}
\hline & 2010 & 2020 & 2030 & 2040 & 2050 & 2100 \\
\hline \multicolumn{7}{|l|}{ United States } \\
\hline Per capita consumption level ${ }^{2}$ & 2.4 & 4.8 & 6.5 & 6.9 & 8.0 & 7. \\
\hline $\begin{array}{l}\text { Per capita GNP level } \\
\text { of which : }\end{array}$ & 3.1 & 6.5 & 8.6 & 8.8 & 9.5 & 8.1 \\
\hline Capital deepening & -0.6 & 0.5 & 1.5 & 2.5 & 2.6 & 1 \\
\hline Participation rate & 3.8 & 6.4 & 7.3 & 6.1 & 6.7 & 5.9 \\
\hline Investment income & -0.0 & 0.0 & 0.2 & 0.4 & 0.5 & 0.8 \\
\hline Terms of trade & -0.1 & -0.4 & -0.4 & -0.3 & -0.2 & -0.3 \\
\hline \multicolumn{7}{|l|}{ Japan } \\
\hline Per capita consumption level ${ }^{2}$ & 0.2 & 5.0 & 8.5 & 13.3 & 13.7 & 13. \\
\hline Per capita GNP level ${ }^{3}$ & 1.1 & 8.5 & 12.8 & 18.1 & 18.1 & 13.7 \\
\hline of which: & & & & & & \\
\hline Capital deepening & -0.3 & -0.5 & 1.4 & 2.2 & 3.9 & 1.6 \\
\hline Participation rate & 1.4 & 9.2 & 11.5 & 15.6 & 12.9 & 9.4 \\
\hline Investment income & 0.1 & 0.3 & 0.8 & 1.4 & 2.2 & 2. \\
\hline Terms of trade & -0.1 & -0.4 & -0.9 & -1.0 & -0.9 & 0.6 \\
\hline \multicolumn{7}{|l|}{ European Union } \\
\hline Per capita consumption level ${ }^{2}$ & 2.0 & 6.1 & 10.2 & 10.0 & 11.1 & \\
\hline Per capita GNP level $^{3}$ & 2.4 & 8.1 & 13.4 & 13.6 & 14.1 & 10.3 \\
\hline of which : & & & & & & \\
\hline Capital deepening & -0.5 & -0.2 & 0.7 & 3.1 & 3.4 & \\
\hline Participation rate & 3.1 & 8.8 & 13.6 & 11.0 & 10.4 & 7 \\
\hline Investment income & -0.1 & -0.2 & -0.0 & 0.5 & 1.2 & 1.0 \\
\hline Terms of trade & -0.1 & -0.3 & -0.9 & -0.9 & -0.8 & 0.0 \\
\hline \multicolumn{7}{|l|}{ Other fast ageing countries } \\
\hline Per capita consumption level ${ }^{2}$ & -0.2 & 0.5 & 1.8 & 2.7 & 2.8 & 0.5 \\
\hline Per capita GNP level ${ }^{3}$ & 0.2 & 1.2 & 2.3 & 2.7 & 2.6 & 1.1 \\
\hline of which : & & & & & & \\
\hline Capital deepening & 0.1 & 0.8 & 1.8 & 2.6 & 2.9 & 1 \\
\hline Investment income & 0.0 & 0.1 & -0.1 & -0.5 & -1.0 & -1.0 \\
\hline Terms of trade & 0.1 & 0.4 & 0.6 & 0.7 & 0.6 & 0.3 \\
\hline \multicolumn{7}{|l|}{ Slow ageing countries } \\
\hline Per capita consumption level ${ }^{2}$ & -0.2 & 0.7 & 1.8 & 2.5 & 2.3 & -0.1 \\
\hline Per capita GNP level ${ }^{3}$ & 0.2 & 1.2 & 2.3 & 2.5 & 2.2 & 0.5 \\
\hline \multicolumn{7}{|l|}{ of which : } \\
\hline Capital deepening & 0.2 & 0.9 & 1.9 & 2.5 & 2.6 & \\
\hline $\begin{array}{l}\text { Investment income } \\
\text { Terms of trade }\end{array}$ & $\begin{array}{l}0.0 \\
0.1\end{array}$ & $\begin{array}{r}-0.0 \\
0.3\end{array}$ & $\begin{array}{r}-0.2 \\
0.6\end{array}$ & $\begin{array}{r}-0.6 \\
0.6\end{array}$ & $\begin{array}{r}-0.9 \\
0.4\end{array}$ & $\begin{array}{l}-1.2 \\
-0.2\end{array}$ \\
\hline & 0.1 & 0.3 & 0.6 & 0.6 & 0.4 & \\
\hline
\end{tabular}

1. Retirement age is assumed to increase by 5 years to a maximun of 70 years in the main OECD regions (see table 7 for more details). Debt to GDP ratios are kept constant in the main OECD regions at their estimated level at the beginning of the projection period through reductions in expenditures.

2. Measured as total private and public consumption per capita.

3. Measured as GNP per capita adjusted for terms of trade effects (see Technical Annex for details of the calculation) 
Table 11. Effects of an increase in the retirement age with debt reduction in the US \& Europe ${ }^{1}$

Difference from reference case in percent

\begin{tabular}{|c|c|c|c|c|c|c|}
\hline & 2010 & 2020 & 2030 & 2040 & 2050 & 2100 \\
\hline \multicolumn{7}{|l|}{ United States } \\
\hline Per capita consumption level ${ }^{2}$ & 2.0 & 4.3 & 6.5 & 7.6 & 9.1 & 8.7 \\
\hline $\begin{array}{l}\text { Per capita GNP level }{ }^{3} \\
\text { of which : }\end{array}$ & 3.1 & 7.2 & 9.9 & 10.6 & 11.5 & 10.2 \\
\hline Capital deepening & -0.5 & 1.0 & 2.5 & 3.7 & 3.8 & 2.7 \\
\hline Participation rate & 3.8 & 6.4 & 7.3 & 6.1 & 6.7 & 5.9 \\
\hline Investment income & -0.0 & 0.2 & 0.6 & 1.0 & 1.2 & 1.6 \\
\hline Terms of trade & -0.2 & -0.4 & -0.4 & -0.3 & -0.2 & -0.0 \\
\hline \multicolumn{7}{|l|}{ Japan } \\
\hline Per capita consumption level ${ }^{2}$ & 0.2 & 5.4 & 9.2 & 14.0 & 14.3 & 12.9 \\
\hline Per capita GNP level ${ }^{3}$ & 1.4 & 8.9 & 13.7 & 18.7 & 18.6 & 13.2 \\
\hline of which : & & & & & & \\
\hline Capital deepening & -0.1 & 0.1 & 2.4 & 3.1 & 5.0 & 2.2 \\
\hline Participation rate & 1.4 & 9.2 & 11.5 & 15.6 & 12.9 & 9.4 \\
\hline Investment income & 0.1 & 0.2 & 0.6 & 1.1 & 1.7 & 1.4 \\
\hline Terms of trade & -0.1 & -0.5 & -0.8 & -1.1 & -0.9 & 0.0 \\
\hline \multicolumn{7}{|l|}{ European Union } \\
\hline Per capita consumption level ${ }^{2}$ & 1.6 & 5.6 & 10.2 & 10.8 & 12.3 & 11.3 \\
\hline Per capita GNP level ${ }^{3}$ & 2.6 & 8.7 & 15.1 & 15.5 & 16.2 & 11.8 \\
\hline of which : & & & & & & \\
\hline Capital deepening & -0.4 & 0.4 & 1.9 & 4.3 & 4.7 & 2.4 \\
\hline Participation rate & 3.1 & 8.8 & 13.6 & 11.0 & 10.4 & 7.7 \\
\hline Investment income & -0.0 & 0.0 & 0.4 & 1.2 & 1.9 & 1.7 \\
\hline Terms of trade & -0.1 & -0.5 & -0.9 & -1.0 & -0.7 & 0.0 \\
\hline \multicolumn{7}{|l|}{ Other fast ageing countries } \\
\hline Per capita consumption level $\left.\right|^{2}$ & -0.2 & 0.9 & 2.5 & 3.4 & 3.3 & 1.3 \\
\hline Per capita GNP level ${ }^{3}$ & 0.4 & 1.8 & 3.0 & 3.5 & 3.2 & 1.9 \\
\hline of which : & & & & & & \\
\hline Capital deepening & 0.3 & 1.5 & 2.8 & 3.8 & 4.1 & 3.3 \\
\hline Investment income & 0.0 & -0.1 & -0.4 & -1.0 & -1.5 & -1.6 \\
\hline Terms of trade & 0.1 & 0.4 & 0.6 & 0.7 & 0.6 & 0.2 \\
\hline \multicolumn{7}{|l|}{ Slow ageing countries } \\
\hline Per capita consumption level ${ }^{2}$ & -0.1 & 1.0 & 2.4 & 3.1 & 2.8 & 0.7 \\
\hline Per capita GNP level ${ }^{3}$ & 0.5 & 1.9 & 2.9 & 3.2 & 2.7 & 1.6 \\
\hline \multicolumn{7}{|l|}{ of which : } \\
\hline Capital deepening & 0.4 & 1.6 & 2.8 & 3.6 & 3.8 & 3.3 \\
\hline Investment income & -0.0 & -0.2 & -0.5 & -1.0 & -1.4 & -1.6 \\
\hline Terms of trade & 0.1 & 0.4 & 0.6 & 0.6 & 0.4 & -0.2 \\
\hline
\end{tabular}

1. Retirement age is assumed to increase by 5 years to a maximun of 70 years in the main OECD regions (see table 7 for more details). Debt to GDP ratios are assumed to fall by 20 percentage points in the United State and the European Union between 2003 and 2020 and to remain stable thereafter. In Japan, the debt to GDP ratio is assumed to remain constant at its estimated level at the beginning of the projection period.

2. Measured as total private and public consumption per capita.

3. Measured as GNP per capita adjusted for terms of trade effects (see Technical Annex for details of the calculation) 
Table 12. Effects of debt stabilisation with an increase in the retirement age inplemented with a 10 year lag ${ }^{1}$

Difference from reference case in percent

\begin{tabular}{|c|c|c|c|c|c|c|}
\hline Per capita consumption level ${ }^{2}$ & -0.2 & 1.7 & 5.5 & 6.4 & 7.8 & 7.1 \\
\hline Per capita GNP level ${ }^{3}$ & 0.1 & 2.7 & 7.8 & 8.4 & 9.3 & 8.0 \\
\hline \multicolumn{7}{|l|}{ of which : } \\
\hline Capital deepening & 0.1 & -0.0 & 0.8 & 2.2 & 2.5 & 1.4 \\
\hline Participation rate & 0.0 & 2.7 & 7.3 & 6.1 & 6.7 & 5.9 \\
\hline Investment income & -0.0 & 0.0 & 0.1 & 0.3 & 0.4 & 0.9 \\
\hline Terms of trade & -0.0 & -0.1 & -0.4 & -0.3 & -0.3 & -0.2 \\
\hline \multicolumn{7}{|l|}{ Japan } \\
\hline Per capita consumption level ${ }^{2}$ & -0.0 & 2.5 & 7.7 & 12.4 & 12.7 & 12.3 \\
\hline $\begin{array}{l}\text { Per capita GNP level }{ }^{3} \\
\text { f }\end{array}$ & -0.0 & 4.1 & 11.2 & 16.6 & 16.7 & 11.6 \\
\hline $\begin{array}{l}\text { of which: } \\
\text { Capital deepening }\end{array}$ & 0.0 & -0.7 & 0.3 & 1.5 & 3.5 & 10 \\
\hline Participation rate & 0.0 & 5.0 & 11.5 & 15.6 & 12.9 & 9.4 \\
\hline Investment income & 0.0 & 0.0 & 0.2 & 0.5 & 1.3 & 1.2 \\
\hline Terms of trade & -0.0 & -0.2 & -0.8 & -1.0 & -1.0 & -0.1 \\
\hline \multicolumn{7}{|l|}{ European Union } \\
\hline Per capita consumption level ${ }^{2}$ & -0.2 & 1.5 & 7.2 & 9.1 & 10.6 & 10.5 \\
\hline Per capita GNP level ${ }^{3}$ & 0.1 & 2.8 & 10.4 & 13.1 & 14.1 & 10.0 \\
\hline $\begin{array}{l}\text { of which : } \\
\text { Capital deepening }\end{array}$ & 0.1 & -0.2 & -0.0 & 23 & 31 & \\
\hline Participation rate & 0.0 & 3.0 & 10.9 & 11.0 & 10.4 & 7.7 \\
\hline Investment income & 0.0 & 0.1 & 0.1 & 0.6 & 1.2 & 1.2 \\
\hline Terms of trade & -0.0 & -0.1 & -0.6 & -0.8 & -0.7 & -0.1 \\
\hline \multicolumn{7}{|l|}{ Other fast ageing countries } \\
\hline Per capita consumption level ${ }^{2}$ & -0.2 & 0.2 & 1.1 & 2.4 & 2.8 & 0.6 \\
\hline Per capita GNP level ${ }^{3}$ & 0.2 & 0.6 & 1.8 & 2.6 & 2.5 & 1.1 \\
\hline Capital deepening & 0.1 & 0.6 & 1.3 & 2.3 & 2.7 & 1.7 \\
\hline Investment income & 0.0 & 0.0 & -0.0 & -0.4 & -0.8 & -0.9 \\
\hline Terms of trade & 0.0 & 0.1 & 0.5 & 0.6 & 0.6 & 0.4 \\
\hline \multicolumn{7}{|l|}{ Slow ageing countries } \\
\hline Per capita consumption level ${ }^{2}$ & -0.1 & 0.3 & 1.2 & 2.3 & 2.4 & -0.1 \\
\hline Per capita GNP level ${ }^{3}$ & 0.2 & 0.7 & 1.8 & 2.4 & 2.2 & \\
\hline Capital deepening & 0.2 & 0.7 & 1.5 & 2.3 & 2.6 & 1.7 \\
\hline Investment income & -0.0 & -0.1 & -0.2 & -0.4 & -0.8 & -1.1 \\
\hline Terms of trade & 0.0 & 0.1 & 0.5 & 0.5 & 0.4 & \\
\hline
\end{tabular}

1. Reforms increasing the retirement age are assumed to be implemented with 10 years delay. Debt to GDP ratios are assumed to evolve broadly in line with the reference scenario until 2015 in the main OECD regions and to remain stable at that level thereafter.

2. Measured as total private and public consumption per capita.

3. Measured as GNP per capita adjusted for terms of trade effects (see Technical Annex for details of the calculation) 


\section{Table 13. Effects of higher labour force participation rates} and lower European unemployment rate ${ }^{1}$

Difference from reference case in percent

\begin{tabular}{|c|c|c|c|c|c|c|}
\hline & 2010 & 2020 & 2030 & 2040 & 2050 & 2100 \\
\hline \multicolumn{7}{|l|}{ United States } \\
\hline Per capita consumption level ${ }^{2}$ & 1.4 & 3.0 & 4.9 & 6.6 & 7.2 & 7.6 \\
\hline $\begin{array}{l}\text { Per capita GNP level }{ }^{3} \\
\text { of which. }\end{array}$ & 1.2 & 3.1 & 5.1 & 6.8 & 7.3 & 7.6 \\
\hline $\begin{array}{l}\text { of which : } \\
\text { Capital deepening }\end{array}$ & \multicolumn{6}{|c|}{ of which: } \\
\hline Participation rate & $\begin{array}{r}-0.0 \\
1.7\end{array}$ & $\begin{array}{r}-0.1 \\
3.9\end{array}$ & $\begin{array}{r}-0.1 \\
5.9\end{array}$ & $\begin{array}{r}-0.4 \\
7.5\end{array}$ & $\begin{array}{r}-0.1 \\
7.7\end{array}$ & $\begin{array}{l}0.0 \\
7.9\end{array}$ \\
\hline Investment income & -0.0 & 0.0 & 0.1 & 0.1 & 0.0 & -0.0 \\
\hline Terms of trade & -0.0 & -0.1 & -0.1 & -0.2 & -0.3 & -0.3 \\
\hline \multicolumn{7}{|l|}{ Japan } \\
\hline Per capita consumption level ${ }^{2}$ & 0.9 & 1.5 & 1.2 & 0.9 & 0.8 & 2.0 \\
\hline Per capita GNP level ${ }^{3}$ & 0.9 & 1.7 & 1.5 & 1.1 & 0.7 & 2.0 \\
\hline $\begin{array}{l}\text { of which: } \\
\text { Capital deepening }\end{array}$ & -0.6 & -0.7 & -0.3 & 0.0 & 0.1 & -0.0 \\
\hline Participation rate & 1.4 & 2.5 & 1.8 & 0.7 & 0.1 & 1.9 \\
\hline Investment income & 0.0 & 0.1 & 0.1 & 0.2 & 0.1 & -0.1 \\
\hline Terms of trade & -0.1 & -0.1 & -0.0 & 0.2 & 0.3 & 0.2 \\
\hline \multicolumn{7}{|l|}{ European Union } \\
\hline Per capita consumption level ${ }^{2}$ & 5.6 & 10.8 & 15.9 & 18.5 & 19.7 & 21.7 \\
\hline Per capita GNP level ${ }^{3}$ & 5.0 & 10.3 & 16.3 & 19.5 & 20.8 & 21.9 \\
\hline \multicolumn{7}{|l|}{ of which: } \\
\hline Capital deepening & -1.1 & -1.7 & -1.7 & -0.9 & -0.1 & 0.0 \\
\hline Participation rate & 2.1 & 8.8 & 15.7 & 18.5 & 18.8 & 18.8 \\
\hline Unemployment rate & 4.3 & 4.3 & 4.3 & 4.3 & 4.3 & 4.3 \\
\hline Investment income & -0.3 & -0.8 & -1.1 & -1.0 & -0.8 & 0.1 \\
\hline Terms of trade & 0.0 & -0.4 & -1.0 & -1.3 & -1.5 & -1.3 \\
\hline \multicolumn{7}{|l|}{ Other fast ageing countries } \\
\hline Per capita consumption level ${ }^{2}$ & -0.3 & -0.3 & 0.1 & 0.7 & 1.1 & 0.8 \\
\hline \multirow{2}{*}{\multicolumn{7}{|c|}{ of which: }} \\
\hline & & & & & & \\
\hline Capital deepening & -0.4 & -0.6 & -0.6 & -0.3 & -0.1 & 0.0 \\
\hline Investment income & 0.1 & 0.3 & 0.4 & 0.3 & 0.2 & -0.0 \\
\hline Terms of trade & 0.0 & 0.3 & 0.5 & 0.6 & 0.7 & 0.7 \\
\hline \multicolumn{7}{|l|}{ Slow ageing countries } \\
\hline Per capita consumption level ${ }^{2}$ & -0.3 & -0.3 & 0.1 & 0.8 & 1.1 & 0.6 \\
\hline Per capita GNP level ${ }^{3}$ & -0.3 & -0.1 & 0.3 & 0.8 & 0.9 & 0.5 \\
\hline \multicolumn{7}{|l|}{ of which: } \\
\hline Capital deepening & -0.4 & -0.5 & -0.4 & -0.2 & -0.0 & -0.0 \\
\hline Investment income & 0.1 & 0.3 & 0.4 & 0.4 & 0.3 & -0.0 \\
\hline Terms of trade & -0.0 & 0.1 & 0.4 & 0.6 & 0.7 & 0.5 \\
\hline
\end{tabular}

1. Participation rates for age groups 25-29 to 40-44 in Japan are assumed to increase to corresponding levels in the European Union and the United States. In the United States and the European Union participation rates of age group above 40 are assumed to reach corresponding level in Japan. In the European Union, the unemployment rate is also assumed to fall from 9.5 per cent to 5.5 per cent by 2010 .

2. Measured as total private and public consumption per capita.

3. Measured as GNP per capita adjusted for terms of trade effects (see Technical Annex for details of the calculation) 
Table 14. Effects of higher levels of total factor productivity ${ }^{1}$

Difference from reference case in percent

\begin{tabular}{|c|c|c|c|c|c|c|}
\hline & 2010 & 2020 & 2030 & 2040 & 2050 & 2100 \\
\hline \multicolumn{7}{|l|}{ United States } \\
\hline Per capita consumption level ${ }^{2}$ & 0.2 & 0.7 & 1.3 & 1.8 & 2.0 & 1.8 \\
\hline $\begin{array}{l}\text { Per capita GNP level }{ }^{3} \\
\text { of which : }\end{array}$ & -0.1 & 0.7 & 1.5 & 1.9 & 2.0 & 1.8 \\
\hline Labour efficiency & 0.3 & 1.2 & 1.8 & 1.8 & 1.8 & 1.8 \\
\hline Capital deepening & -0.3 & -0.7 & -0.5 & -0.2 & -0.0 & 0.0 \\
\hline Investment income & 0.0 & 0.1 & 0.2 & 0.2 & 0.1 & -0.0 \\
\hline Terms of trade & -0.0 & 0.0 & 0.1 & 0.1 & 0.1 & 0.0 \\
\hline \multicolumn{7}{|l|}{ Japan } \\
\hline Per capita consumption level ${ }^{2}$ & 5.1 & 8.1 & 7.5 & 8.2 & 9.1 & 10.4 \\
\hline Per capita GNP level ${ }^{3}$ & 3.3 & 7.5 & 8.3 & 9.2 & 10.0 & 10.5 \\
\hline Labour efficiency & 4.6 & 11.1 & 11.1 & 11.1 & 11.1 & 11.1 \\
\hline Capital deepening & -1.1 & -2.1 & -1.0 & -0.2 & 0.2 & -0.0 \\
\hline Investment income & -0.4 & -1.0 & -1.0 & -0.7 & -0.4 & 0.1 \\
\hline Terms of trade & 0.2 & -0.5 & -0.9 & -1.0 & -0.9 & -0.7 \\
\hline \multicolumn{7}{|l|}{ European Union } \\
\hline Per capita consumption level ${ }^{2}$ & 1.7 & 4.7 & 5.9 & 6.1 & 6.6 & 8.0 \\
\hline Per capita GNP level ${ }^{3}$ & 0.8 & 3.6 & 6.0 & 6.7 & 7.3 & 8.1 \\
\hline of which : & & & & & & \\
\hline Labour efficiency & 1.2 & 5.6 & 8.5 & 8.5 & 8.5 & 8.5 \\
\hline Capital deepening & -0.4 & -1.4 & -1.2 & -0.4 & 0.0 & 0.0 \\
\hline Investment income & -0.1 & -0.5 & -0.8 & -0.7 & -0.5 & 0.1 \\
\hline Terms of trade & 0.1 & -0.1 & -0.5 & -0.7 & -0.7 & -0.5 \\
\hline \multicolumn{7}{|l|}{ Other fast ageing countries } \\
\hline Per capita consumption level ${ }^{2}$ & -0.3 & -0.5 & -0.1 & 0.5 & 0.7 & 0.3 \\
\hline Per capita GNP level $^{3}$ & -0.3 & -0.3 & 0.1 & 0.4 & 0.5 & 0.3 \\
\hline of which : & & & & & & \\
\hline Capital deepening & -0.4 & -0.7 & -0.5 & -0.2 & -0.0 & 0.0 \\
\hline Investment income & 0.1 & 0.3 & 0.4 & 0.3 & 0.2 & -0.0 \\
\hline Terms of trade & -0.0 & 0.1 & 0.3 & 0.3 & 0.4 & 0.3 \\
\hline \multicolumn{7}{|l|}{ Slow ageing countries } \\
\hline Per capita consumption level ${ }^{2}$ & -0.3 & -0.5 & -0.0 & 0.5 & 0.7 & 0.2 \\
\hline Per capita GNP level ${ }^{3}$ & -0.4 & -0.3 & 0.2 & 0.5 & 0.5 & 0.2 \\
\hline of which : & & & & & & \\
\hline Capital deepening & -0.4 & -0.6 & -0.4 & -0.1 & -0.0 & 0.0 \\
\hline Investment income & 0.1 & 0.3 & 0.3 & 0.3 & 0.2 & -0.1 \\
\hline Terms of trade & -0.1 & 0.1 & 0.2 & 0.3 & 0.4 & 0.2 \\
\hline
\end{tabular}

1. Labour efficiency levels are assumed to rise by 11.8 percent in Japan by 2020 and by 8.6 per cent in the European Union and 1.8 per cent in the United States by 2030, relative to the reference scenario

2. Measured as total private and public consumption per capita.

3. Measured as GNP per capita adjusted for terms of trade effects (see Technical Annex for details of the calculation) 
Table 15. Effects of faster growth in the two mainly non-OECD regions ${ }^{1}$

Difference from reference case in percent

\begin{tabular}{|c|c|c|c|c|c|c|}
\hline & 2010 & 2020 & 2030 & 2040 & 2050 & 2100 \\
\hline \multicolumn{7}{|l|}{ United States } \\
\hline $\begin{array}{l}\text { Per capita consumption level }{ }^{2} \\
\text { Per capita GNP level }{ }^{3} \\
\text { of which : }\end{array}$ & $\begin{array}{l}-1.1 \\
-2.0\end{array}$ & $\begin{array}{l}-2.9 \\
-2.1\end{array}$ & $\begin{array}{r}-1.6 \\
0.8\end{array}$ & $\begin{array}{l}2.3 \\
4.5\end{array}$ & $\begin{array}{l}6.8 \\
7.0\end{array}$ & $\begin{array}{l}3.0 \\
2.5\end{array}$ \\
\hline $\begin{array}{l}\text { Capital deepening } \\
\text { Investment income } \\
\text { Terms of trade }\end{array}$ & $\begin{array}{r}-1.9 \\
0.3 \\
-0.3\end{array}$ & $\begin{array}{r}-4.2 \\
1.9 \\
0.3\end{array}$ & $\begin{array}{r}-4.5 \\
3.9 \\
1.4\end{array}$ & $\begin{array}{r}-3.3 \\
5.0 \\
2.8\end{array}$ & $\begin{array}{r}-1.4 \\
4.3 \\
4.0\end{array}$ & $\begin{array}{r}-0.2 \\
-0.4 \\
3.0\end{array}$ \\
\hline \multicolumn{7}{|l|}{ Japan } \\
\hline $\begin{array}{l}\text { Per capita consumption level }{ }^{2} \\
\text { Per capita GNP level }{ }^{3} \\
\text { of which: }\end{array}$ & $\begin{array}{l}-0.7 \\
-1.2\end{array}$ & $\begin{array}{l}-1.6 \\
-0.1\end{array}$ & $\begin{array}{l}0.7 \\
3.3\end{array}$ & $\begin{array}{l}5.2 \\
7.2\end{array}$ & $\begin{array}{l}9.8 \\
9.5\end{array}$ & $\begin{array}{l}2.8 \\
1.8\end{array}$ \\
\hline $\begin{array}{l}\text { Capital deepening } \\
\text { Investment income } \\
\text { Terms of trade }\end{array}$ & $\begin{array}{r}-1.9 \\
1.0 \\
-0.3\end{array}$ & $\begin{array}{r}-4.0 \\
3.4 \\
0.6\end{array}$ & $\begin{array}{r}-4.3 \\
5.6 \\
2.0\end{array}$ & $\begin{array}{r}-3.0 \\
6.4 \\
3.9\end{array}$ & $\begin{array}{r}-1.3 \\
5.2 \\
5.5\end{array}$ & $\begin{array}{r}0.1 \\
-1.3 \\
3.0\end{array}$ \\
\hline \multicolumn{7}{|l|}{ European Union } \\
\hline $\begin{array}{l}\text { Per capita consumption level }{ }^{2} \\
\text { Per capita GNP level }{ }^{3} \\
\text { of which : }\end{array}$ & $\begin{array}{l}-0.6 \\
-1.5\end{array}$ & $\begin{array}{l}-2.1 \\
-1.2\end{array}$ & $\begin{array}{r}-0.5 \\
1.9\end{array}$ & $\begin{array}{l}3.5 \\
5.8\end{array}$ & $\begin{array}{l}7.9 \\
8.1\end{array}$ & $\begin{array}{l}2.6 \\
1.9\end{array}$ \\
\hline $\begin{array}{l}\text { Capital deepening } \\
\text { Investment income } \\
\text { Terms of trade }\end{array}$ & $\begin{array}{r}-2.0 \\
0.7 \\
-0.2\end{array}$ & $\begin{array}{r}-4.4 \\
2.8 \\
0.4\end{array}$ & $\begin{array}{r}-4.8 \\
5.1 \\
1.7\end{array}$ & $\begin{array}{r}-3.6 \\
6.2 \\
3.2\end{array}$ & $\begin{array}{r}-1.5 \\
5.3 \\
4.4\end{array}$ & $\begin{array}{r}-0.7 \\
-0.3 \\
2.9\end{array}$ \\
\hline \multicolumn{7}{|l|}{ Other fast ageing countries } \\
\hline $\begin{array}{l}\text { Per capita consumption level }{ }^{2} \\
\text { Per capita GNP level }{ }^{3} \\
\text { of which : }\end{array}$ & $\begin{array}{l}6.1 \\
2.4\end{array}$ & $\begin{array}{r}13.3 \\
8.9\end{array}$ & $\begin{array}{l}20.8 \\
18.1\end{array}$ & $\begin{array}{l}30.4 \\
30.5\end{array}$ & $\begin{array}{l}37.3 \\
41.0\end{array}$ & $\begin{array}{l}48.3 \\
48.6\end{array}$ \\
\hline $\begin{array}{l}\text { Labour efficiency } \\
\text { Capital deepening } \\
\text { Investment income } \\
\text { Terms of trade }\end{array}$ & $\begin{array}{r}5.2 \\
-2.6 \\
-0.4 \\
0.1\end{array}$ & $\begin{array}{l}18.1 \\
-6.8 \\
-1.9 \\
-0.4\end{array}$ & $\begin{array}{l}31.1 \\
-7.9 \\
-3.8 \\
-1.3\end{array}$ & $\begin{array}{l}44.0 \\
-6.7 \\
-4.7 \\
-2.0\end{array}$ & $\begin{array}{l}50.5 \\
-2.8 \\
-4.1 \\
-2.4\end{array}$ & $\begin{array}{r}50.5 \\
0.0 \\
0.4 \\
-2.2\end{array}$ \\
\hline \multicolumn{7}{|l|}{ Slow ageing countries } \\
\hline $\begin{array}{l}\text { Per capita consumption level }{ }^{2} \\
\text { Per capita GNP level } \\
\text { of which : }\end{array}$ & $\begin{array}{l}6.3 \\
2.5\end{array}$ & $\begin{array}{r}13.0 \\
8.6\end{array}$ & $\begin{array}{l}20.3 \\
17.7\end{array}$ & $\begin{array}{l}30.1 \\
30.5\end{array}$ & $\begin{array}{l}37.9 \\
41.9\end{array}$ & $\begin{array}{l}49.0 \\
49.4\end{array}$ \\
\hline $\begin{array}{l}\text { Labour efficiency } \\
\text { Capital deepening } \\
\text { Investment income } \\
\text { Terms of trade }\end{array}$ & $\begin{array}{r}5.2 \\
-2.5 \\
-0.5 \\
0.3\end{array}$ & $\begin{array}{l}18.1 \\
-7.3 \\
-2.0 \\
-0.2\end{array}$ & $\begin{array}{l}31.1 \\
-8.6 \\
-3.7 \\
-1.0\end{array}$ & $\begin{array}{l}44.0 \\
-7.3 \\
-4.5 \\
-1.6\end{array}$ & $\begin{array}{l}50.5 \\
-2.9 \\
-3.9 \\
-1.8\end{array}$ & $\begin{array}{r}50.5 \\
0.1 \\
0.3 \\
-1.5\end{array}$ \\
\hline
\end{tabular}

1. Labour efficiency is assumed to grow by an additional 1 point per annum in the two mainly non-OECD regions

2. Measured as total private and public consumption per capita.

3. Measured as GNP per capita adjusted for terms of trade effects (see Technical Annex for details of the calculation) 
Table 16. Effects of combined reforms ${ }^{1}$

Difference from reference case in percent

\begin{tabular}{lllllll}
\hline 2010 & 2020 & 2030 & 2040 & 2050 & 2100 \\
\hline
\end{tabular}

\section{United States}

Per capita consumption level ${ }^{2}$ Per capita GNP level ${ }^{3}$

$\begin{array}{rr}2.2 & 5.0 \\ 3.2 & 7.8 \\ & \\ 0.3 & 1.2 \\ -0.8 & 0.2 \\ 3.8 & 6.4 \\ 0.1 & 0.3 \\ -0.1 & -0.3\end{array}$

\section{7}

11.4

10.2

13.6

12.1

which.

Labour efficiency

Capital deepening

Participation rate

Investment income

Terms of trade

\section{Japan}

Per capita consumption level ${ }^{2}$

Per capita GNP level ${ }^{3}$

of which :

Labour efficiency

Capital deepening

Participation rate

Investment income

Terms of trade

\section{European Union}

Per capita consumption level ${ }^{2}$

Per capita GNP level ${ }^{3}$

of which :

Labour efficiency

Capital deepening

Participation rate

Unemployment rate

Investment income

Terms of trade

$\begin{array}{rr}6.1 & 15.2 \\ 5.6 & 18.7 \\ & \\ 4.6 & 11 . \\ -1.5 & -2.0 \\ 2.8 & 11.4 \\ -0.3 & -0.8 \\ -0.0 & -1 .\end{array}$

$6.6 \quad 13$

13.9

26.8

32.8

1.8
3.5

1.8

2.0
7.3
0.7

0.7

$-0.3$

7.5

1.0

$-0.2$

18.6

24.1

23.7

29.6

24.4

29.4

11.1

3.3

16.2

11.1

5.4

13.0

1.5

$-1.7$

$-1.5$

1.8
4.1
7.7
1.2
-0.1

12.6

14.2

1.8

3.0

7.9

1.4

0.1

$-0.2$

$-1.5$

$\begin{array}{rr}1.2 & 5.6 \\ -1.6 & -1.3 \\ 3.1 & 8.8\end{array}$

$\begin{array}{rr}-1.6 & -1.3 \\ 3.1 & 8.8 \\ 4.3 & 4.3\end{array}$

$\begin{array}{ll}4.3 & 4.3\end{array}$

$\begin{array}{ll}-0.3 & -0.7\end{array}$

$\begin{array}{ll}-0.1 & -0.8\end{array}$

8.5
0.5
15.7
4.3
-0.6
-1.5

8.5

3.2

18.5

4.3

0.2

$-1.9$

29.9

35.6

35.1

$\begin{array}{ll}8.5 & 8.5 \\ 4.7 & 3.0\end{array}$

$\begin{array}{ll}8.5 & 8.5 \\ 4.7 & 3.0\end{array}$

$18.8 \quad 18.8$

$\begin{array}{rr}18.8 & 18.8 \\ 4.3 & 4.3\end{array}$

$\begin{array}{ll}1.2 & 2.0 \\ -1.9 & -1.5\end{array}$

Other fast ageing countries

Per capita consumption level ${ }^{2}$ Per capita GNP level ${ }^{3}$

$\begin{array}{rr}-0.5 & 0.4 \\ 0.1 & 1.6 \\ -0.2 & 0.7 \\ 0.2 & 0.3 \\ 0.1 & 0.6\end{array}$

$\begin{array}{ll}0.4 & 2.7 \\ 1.6 & 3 . \\ & \\ 0.7 & 2.4 \\ 0.3 & 0.1 \\ 0.6 & 1.1\end{array}$

$\begin{array}{rrrr}2.7 & 4.4 & 4.7 & 2.2 \\ 3.5 & 4.4 & 4.4 & 2.8 \\ & & & \\ 2.4 & 3.7 & 4.4 & 3.4 \\ 0.1 & -0.6 & -1.2 & -1.6 \\ 1.1 & 1.2 & 1.2 & 1.0\end{array}$

\section{Slow ageing countries}

Per capita consumption level ${ }^{2}$ Per capita GNP level ${ }^{3}$

$\begin{array}{rr}-0.5 & 0.6 \\ 0.1 & 1.7 \\ -0.0 & 1.0 \\ 0.1 & 0.2 \\ 0.1 & 0.5\end{array}$

Capital deepening

Investment income

Terms of trade

0.1

$\begin{array}{rr}0.6 & 2.7 \\ 1.7 & 3.4 \\ & \\ 1.0 & 2.5 \\ 0.2 & -0.1 \\ 0.5 & 1.0\end{array}$

4.1

4.2

3.9

1.3

4.1

4.1

3.6
-0.7

1.2

-1.2
1.0

3.6

$-1.8$

1. Combined reforms scenario as described in section 3.4 of the main text.

2. Measured as total private and public consumption per capita.

3. Measured as GNP per capita adjusted for terms of trade effects (see Technical Annex for details of the calculation) 


\section{Figure 1. The underlying demographic projections}

\begin{tabular}{|ll|}
\hline- & USA \\
- & Japan \\
-- & European Union \\
- & Other Fast Ageing countries \\
-- & Slow Ageing countries \\
\hline
\end{tabular}

(a) Population Growth rate (\% pa)

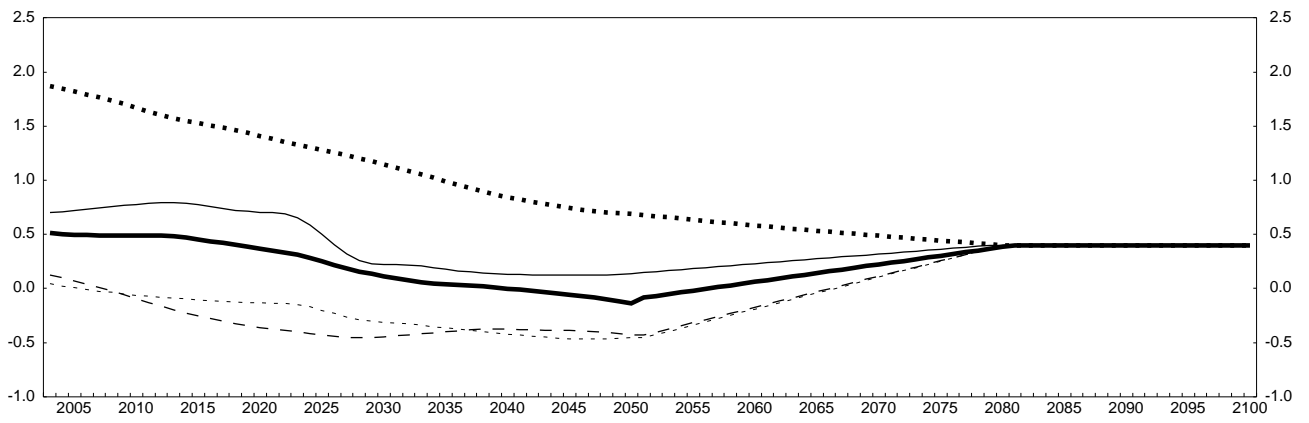

(b) Total dependency ratio (\%)

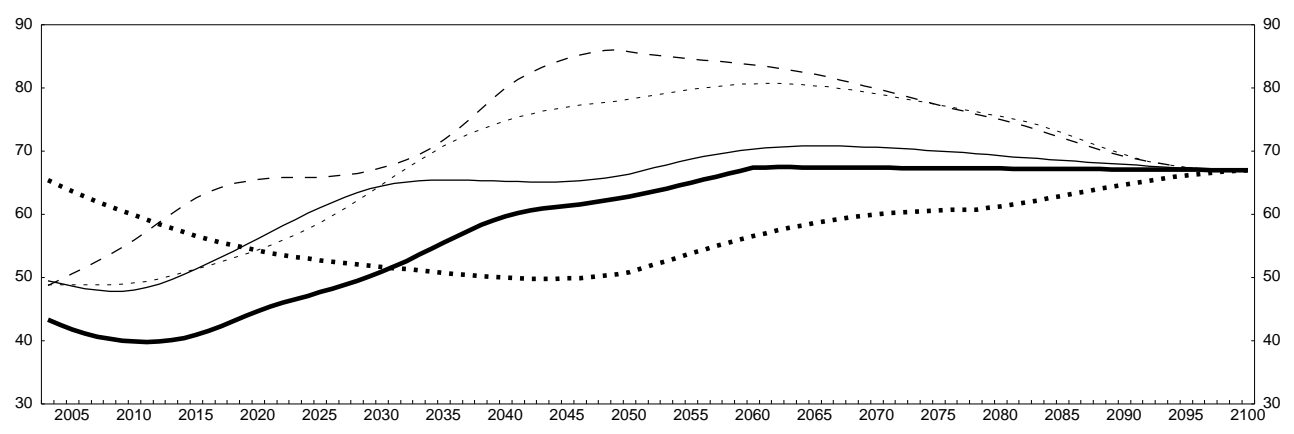

(c) Old age dependency ratio (\%)

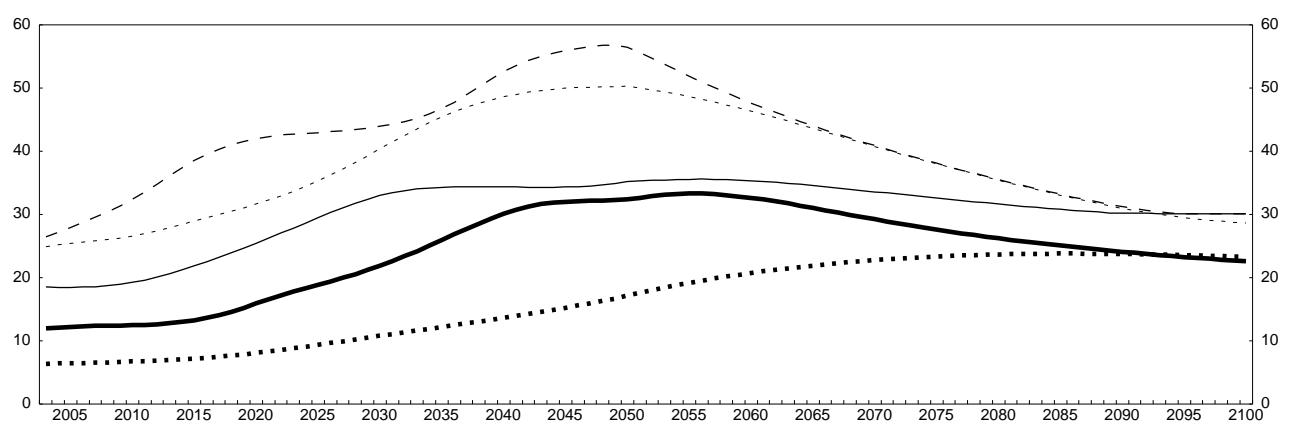


Figure 2. Age composition and labour force participation rates

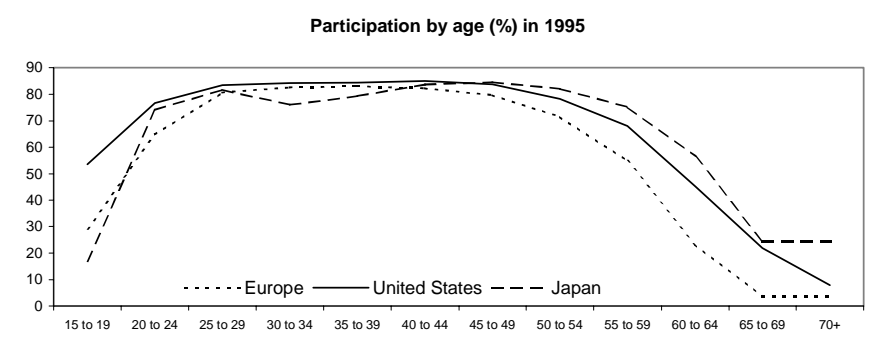

Change in the structure of the population (2000-2050)
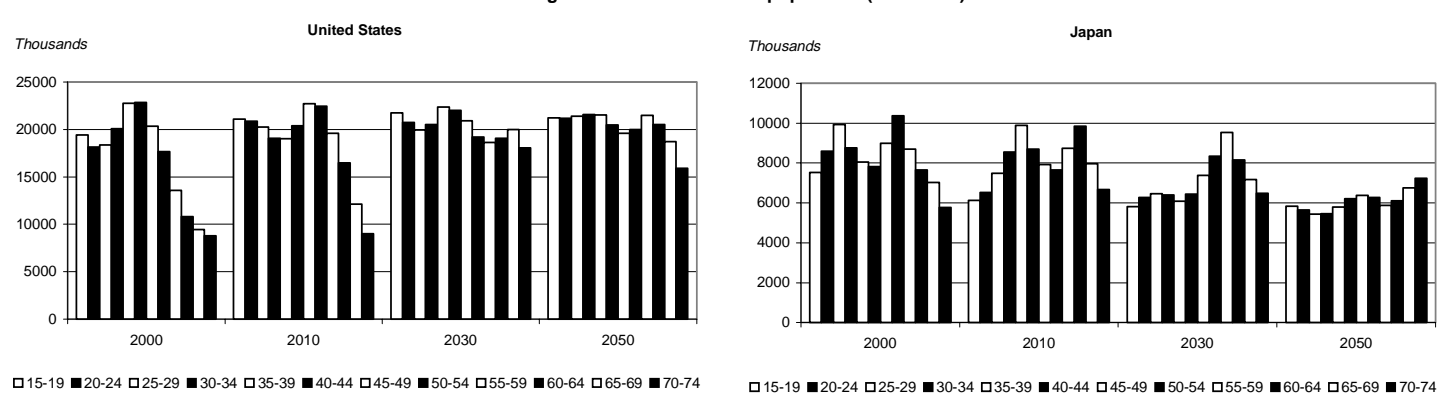

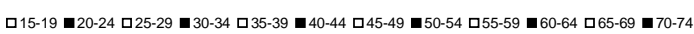
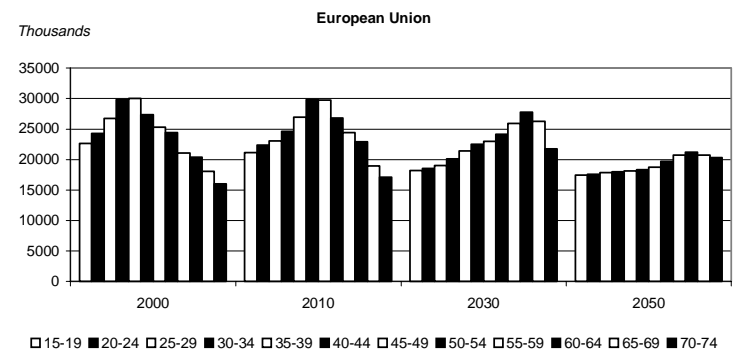

Aggregate participation rate in the OECD regions in the eference scenario*

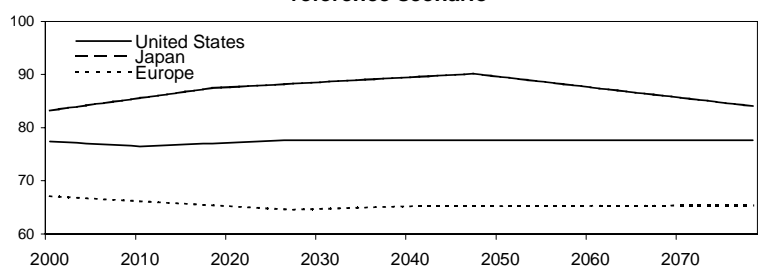

* Estimated on the basis of the projected changes in the age structure of the population over the projection period in the different regions assuming unchanged participation rates by age at their 1995 levels. 
Figure 3. The direct effects of ageing on government finances

(a) Effect of public pension schemes on government financial balances (as a percentage of GDP)

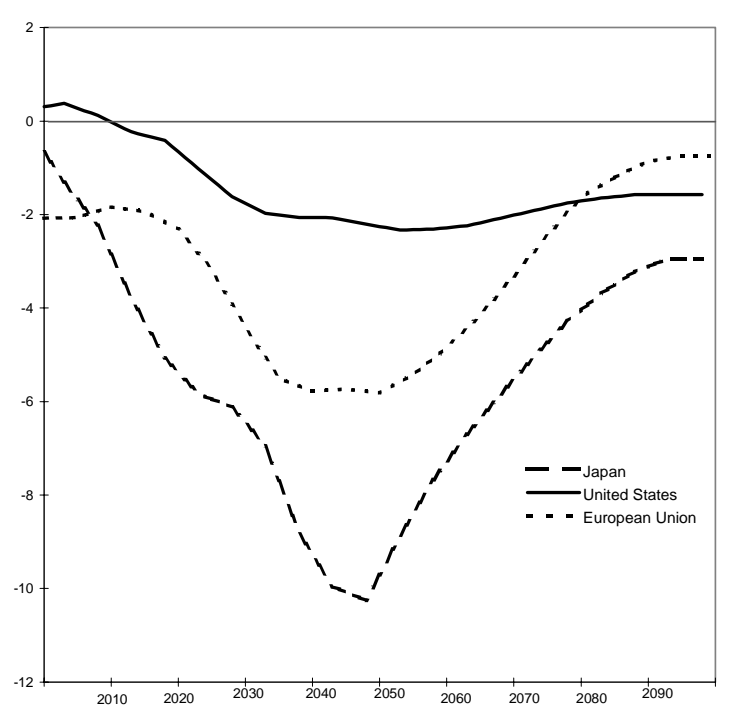

(c) Effect of ageing on government education expenditure (as a percentage of GDP)

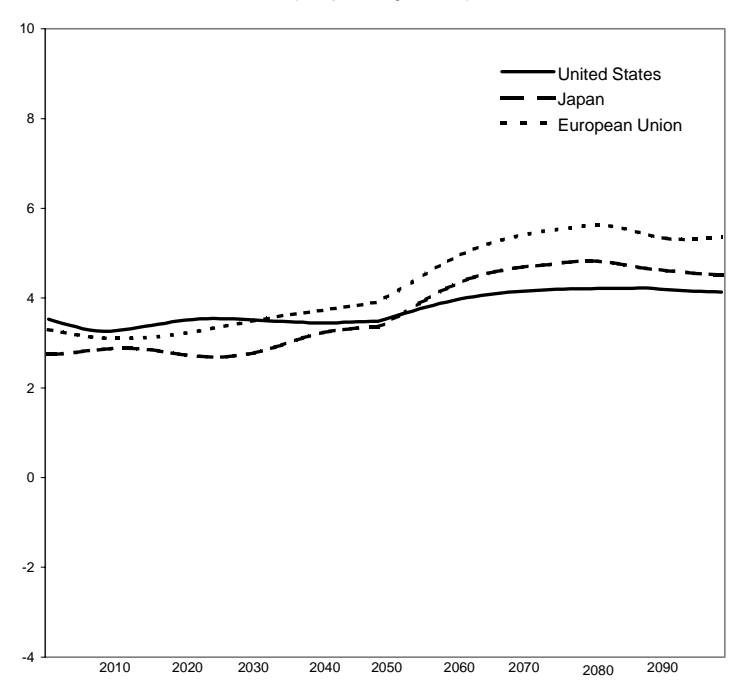

(b) Effect of ageing on government health expenditure (as a percentage of GDP)

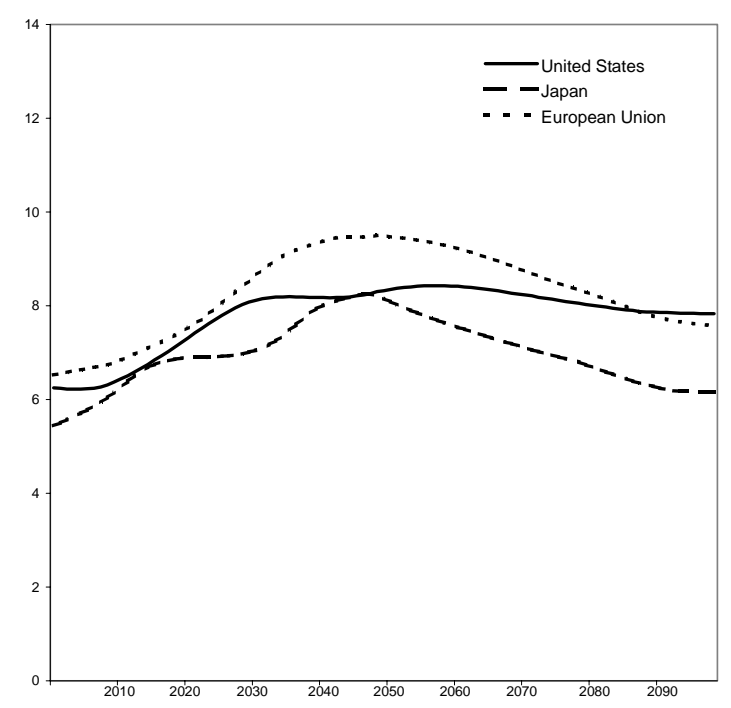

(d) Public debt

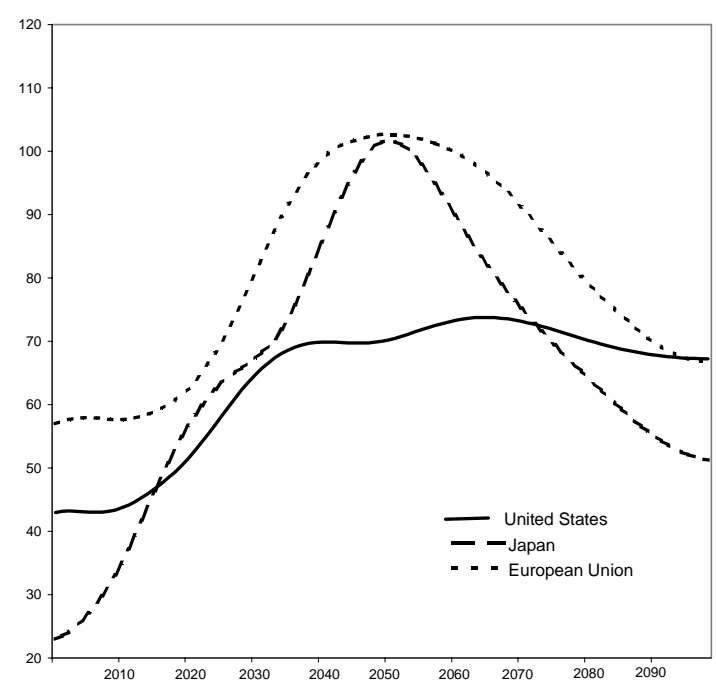


ECO/WKP(98)6

Figure 4. Potential output growth in the reference scenario

\begin{tabular}{ll|}
\hline- & USA \\
-- & Japan \\
-- & European Union \\
-- & Other Fast Ageing countries \\
-- & Slow Ageing countries \\
\hline
\end{tabular}

(a) Potential output growth (\% pa)

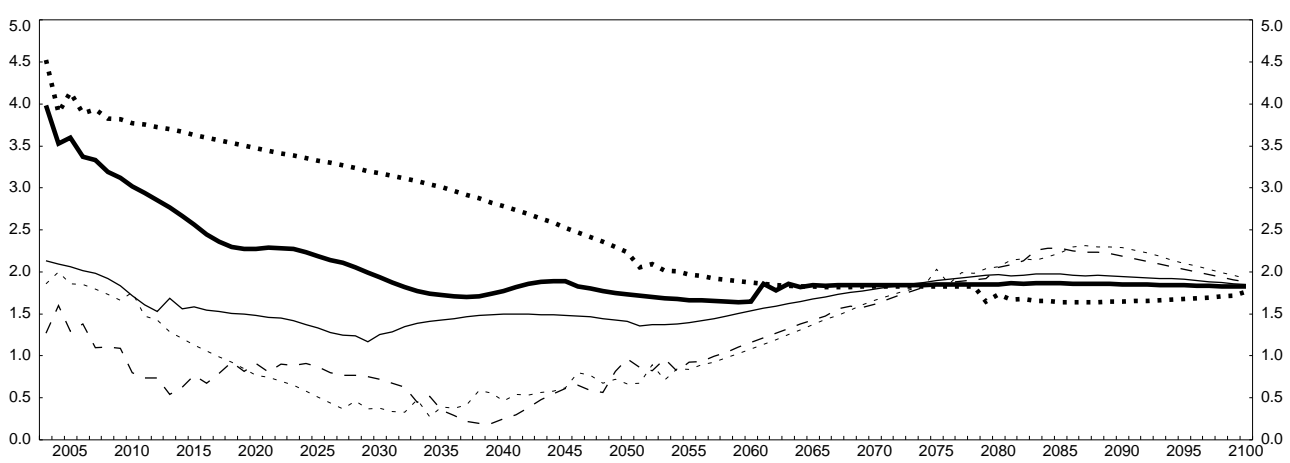

(b) Labour force growth rate (\% pa)

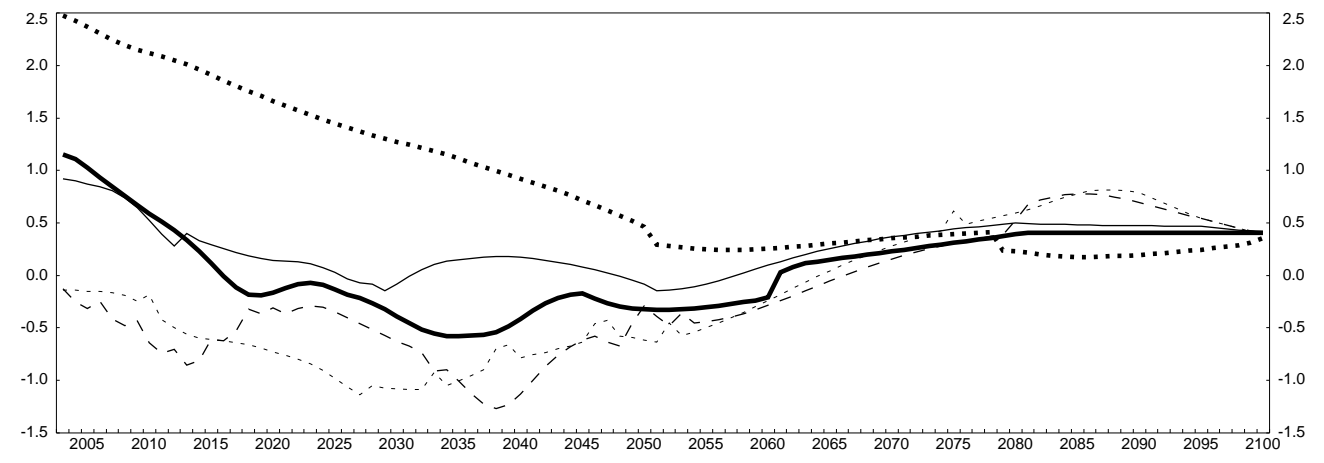

(c) Labour efficiency growth (\% pa)

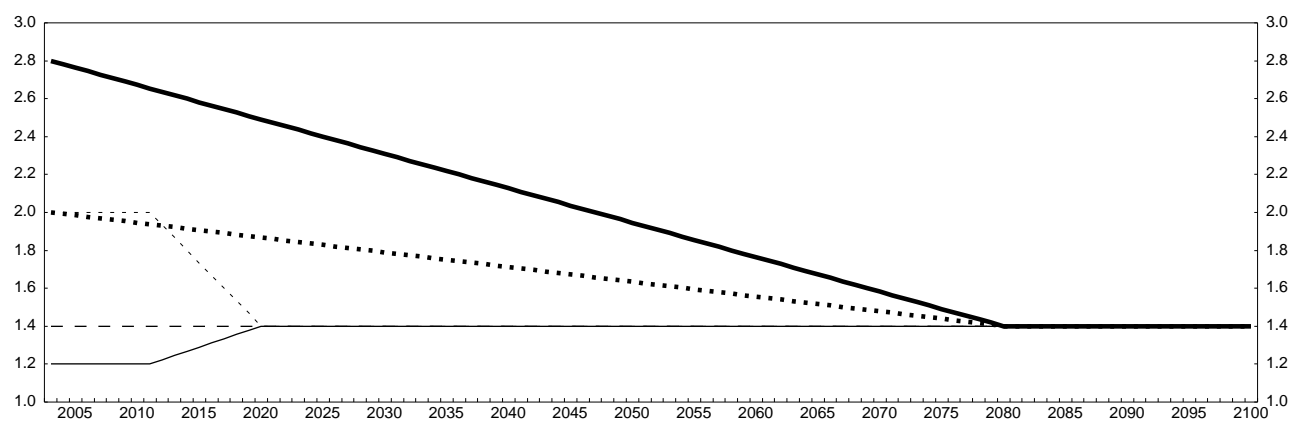


Figure 5. Shares in world GDP (at 1995 purchasing power parities)
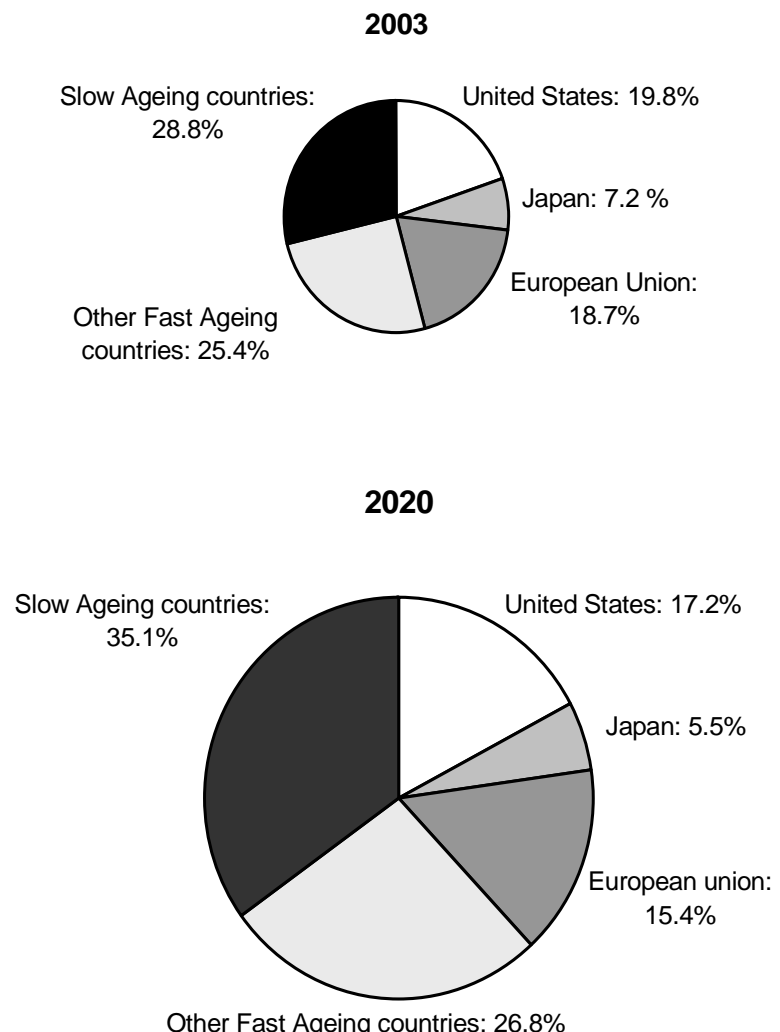

2050

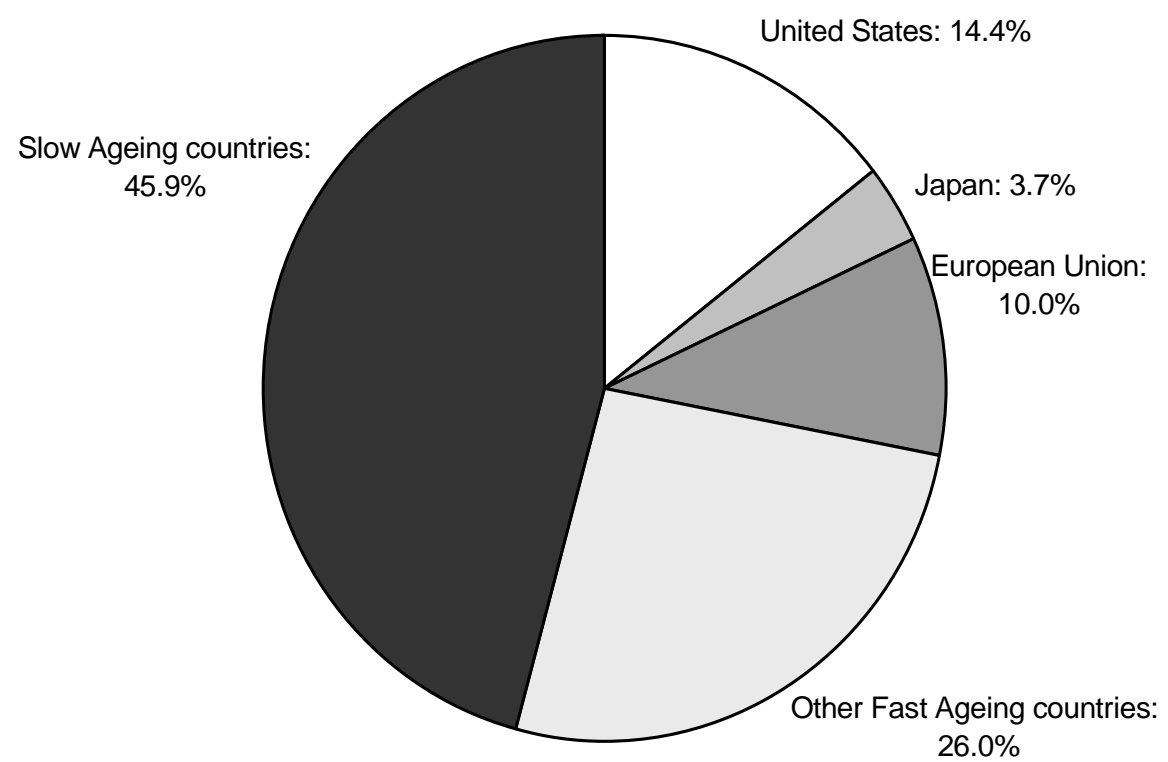


Figure 6. Macroeconomic effects of higher savings(1) Difference from reference case
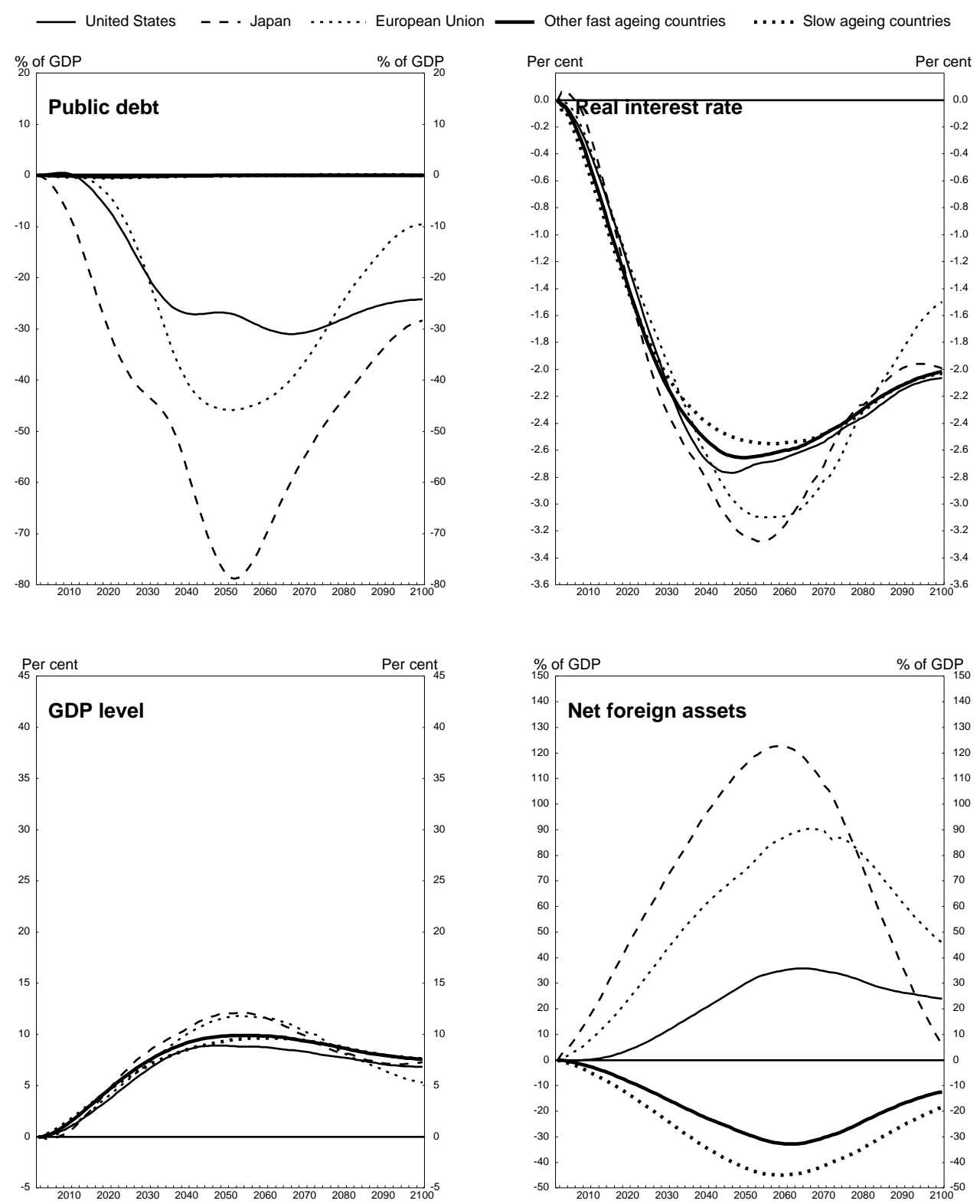

1. The higher-saving scenario abstracts from the direct effects of higher dependency rates on private and public savings in the main OECD regions. 


\section{ECO/WKP(98)6}

Figure 7. Real interest rates and exchange rates:

comparison between reference case and a higher-savings scenario

\section{- Reference Scenario \\ --- Higher-Savings Scenario}

Real Interest rates (\%)

Exchange rate $(2000=1)$
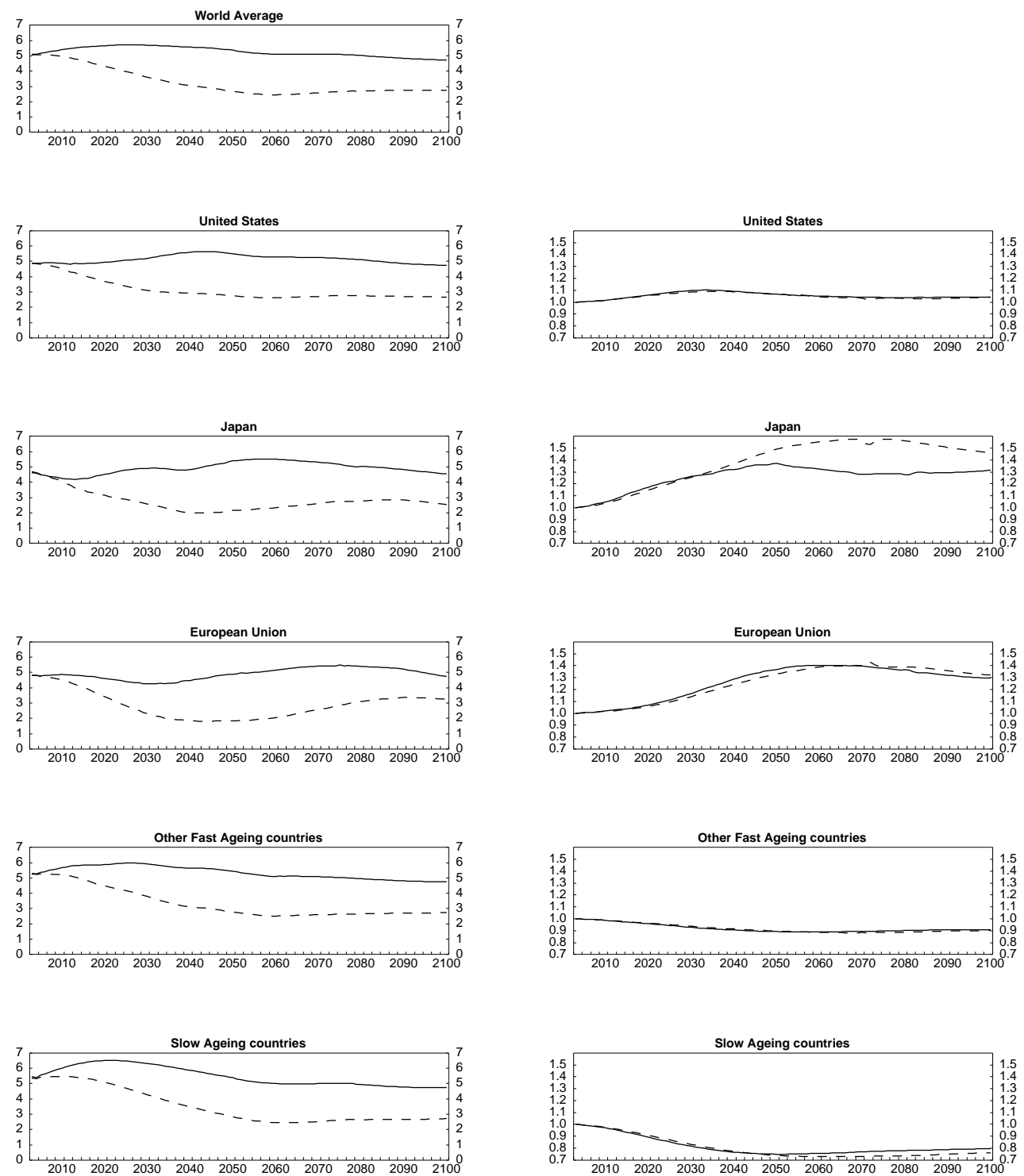
ECO/WKP(98)6

Figure 8. Savings, investment \& current account balances (as \% of GDP) in the reference scenario

$$
\begin{array}{ll}
\ldots & \text { National Savings } \\
-- & \text { Investment } \\
& \text { Current account }
\end{array}
$$

United States

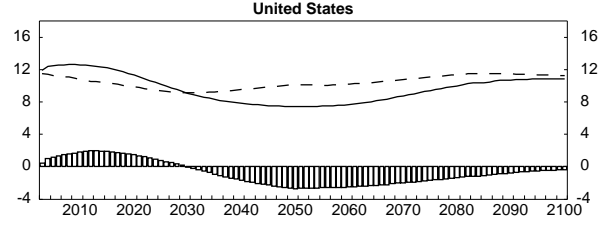

Japan
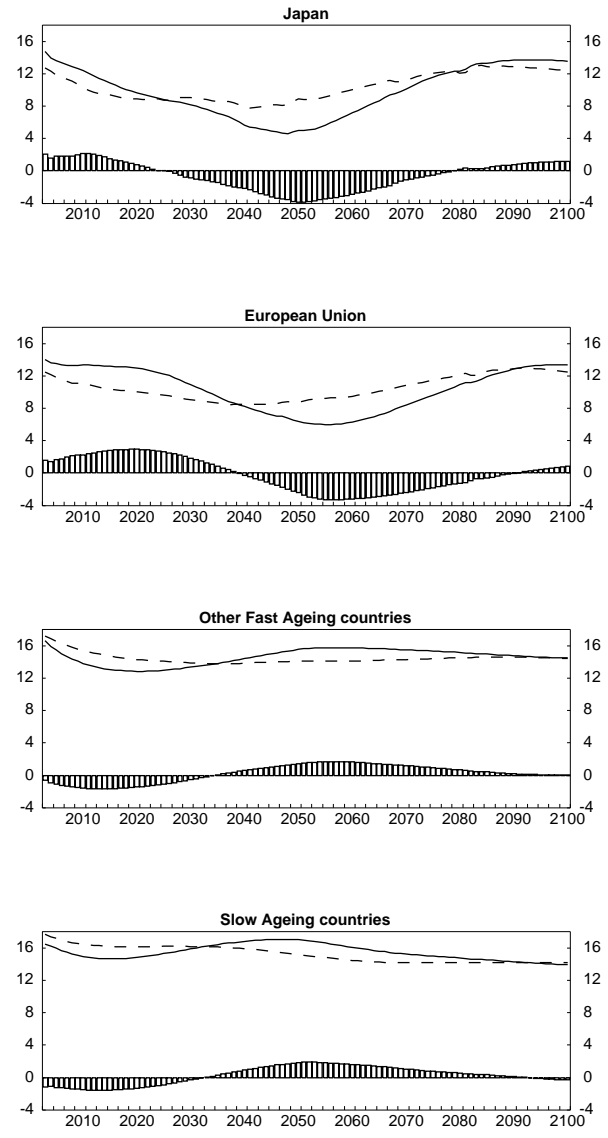

$$
\begin{array}{ll}
\text { - } & \text { National Savings } \\
- & \text { Private savings } \\
-- & \text { Public savings }
\end{array}
$$
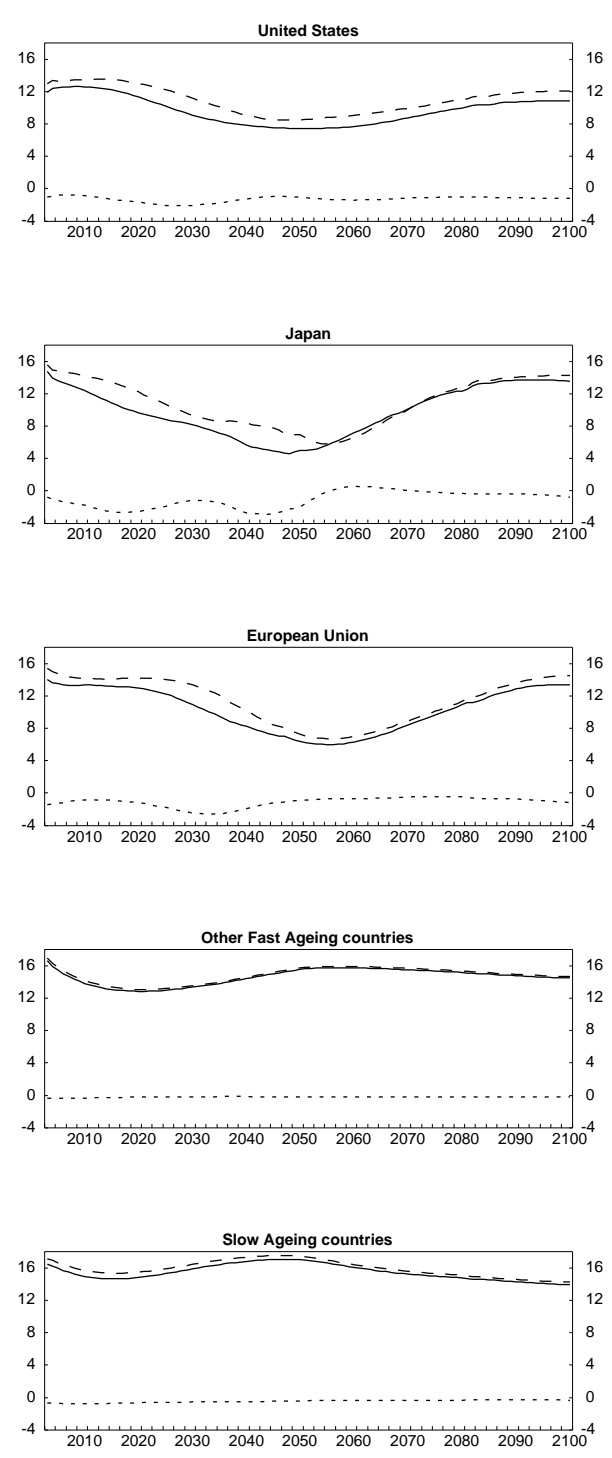


\section{ECO/WKP(98)6}

Figure 9. Current account and net foreign asset positions: comparisons between the reference case and a higher-savings scenario

- Reference Scenario

--- Higher-Savings Scenario

Net foreign assets \% GDP
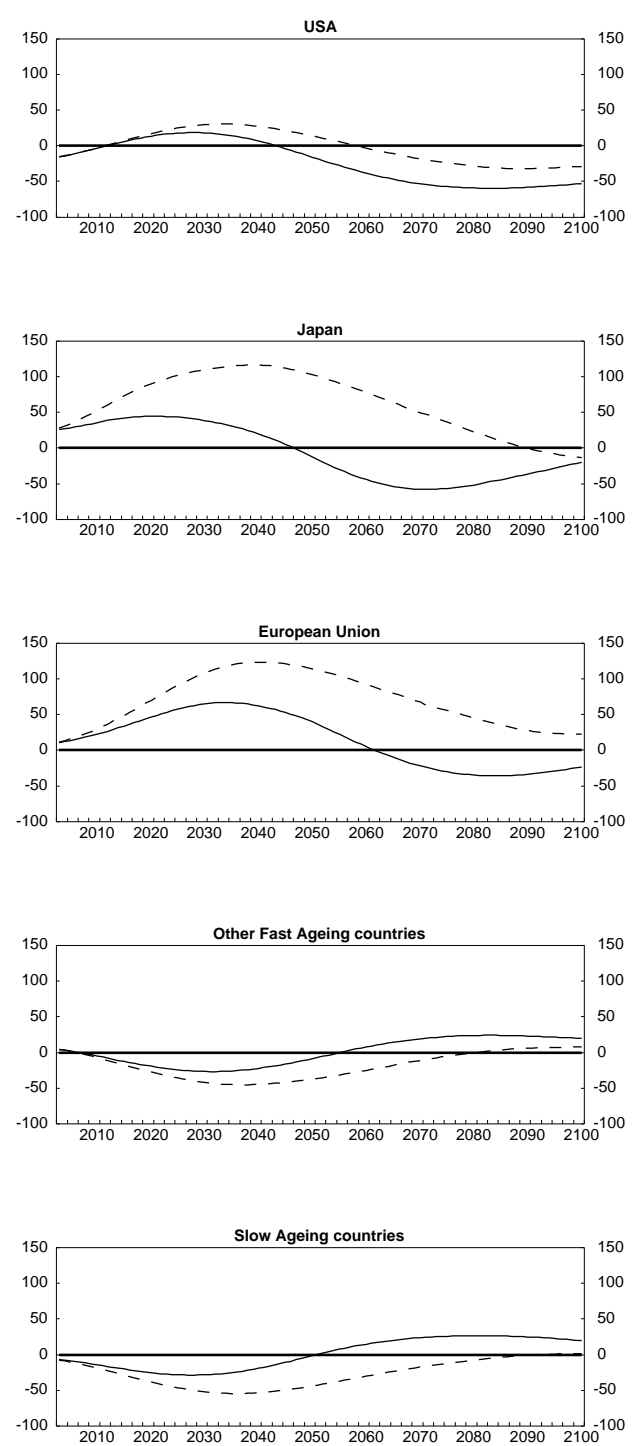

Current Balance in $\%$ of GDP

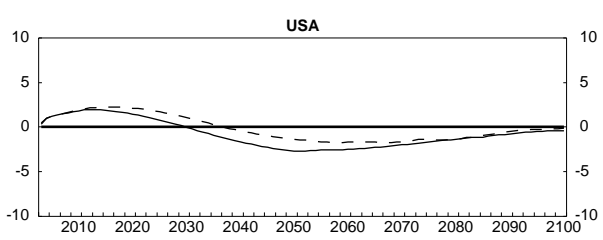

Japan
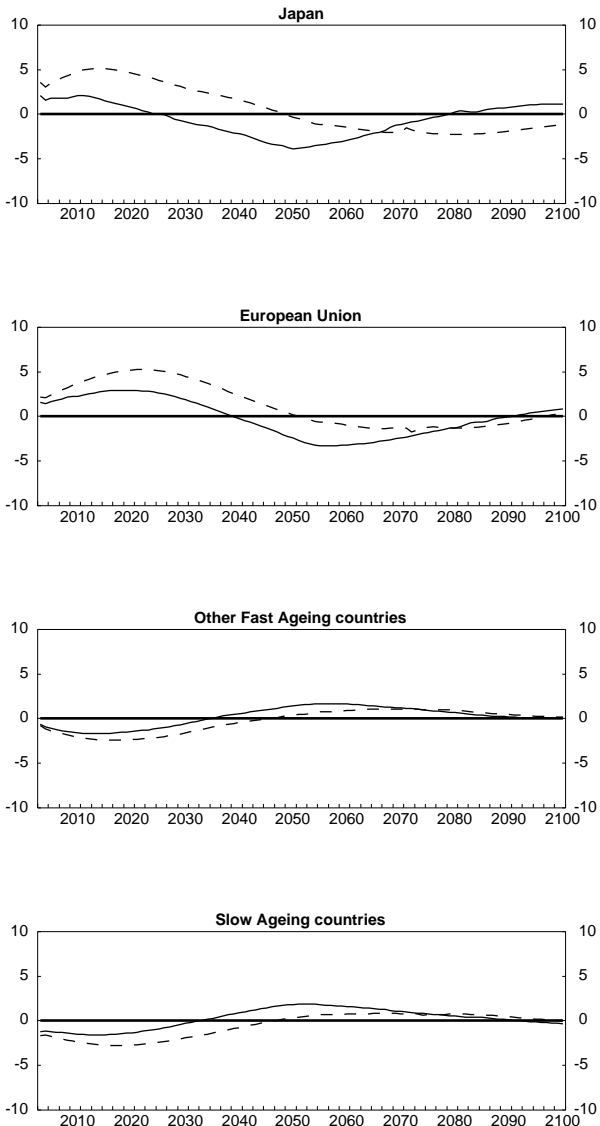
Figure 10. Contributions to annual growth in per capita living standards*

(a) Japan

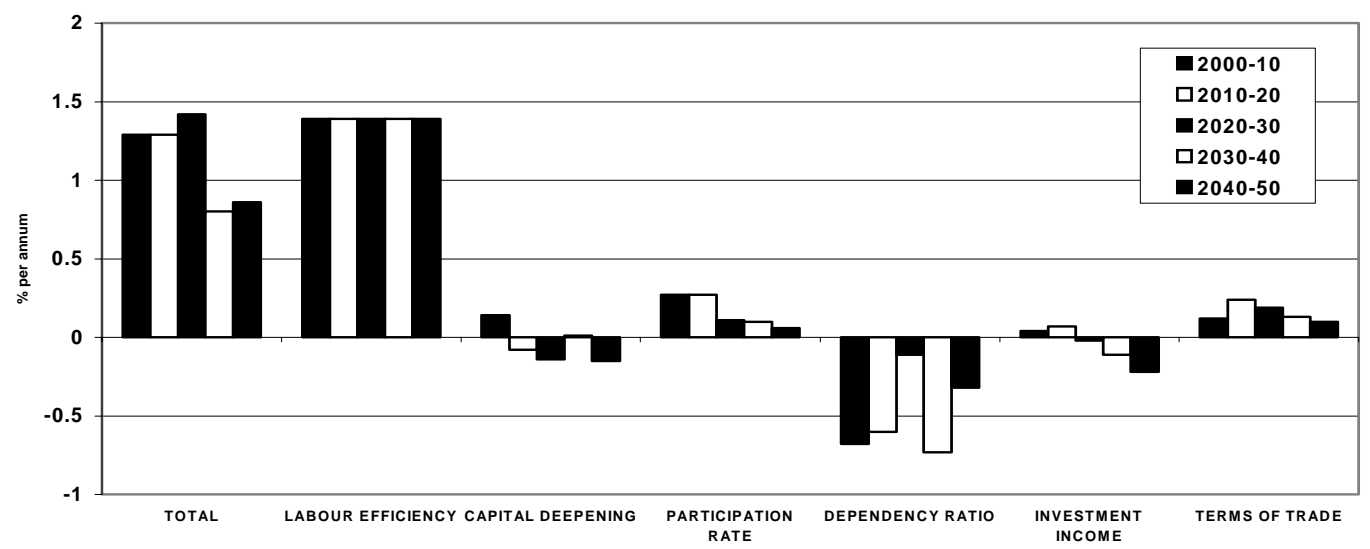

(b) European Union

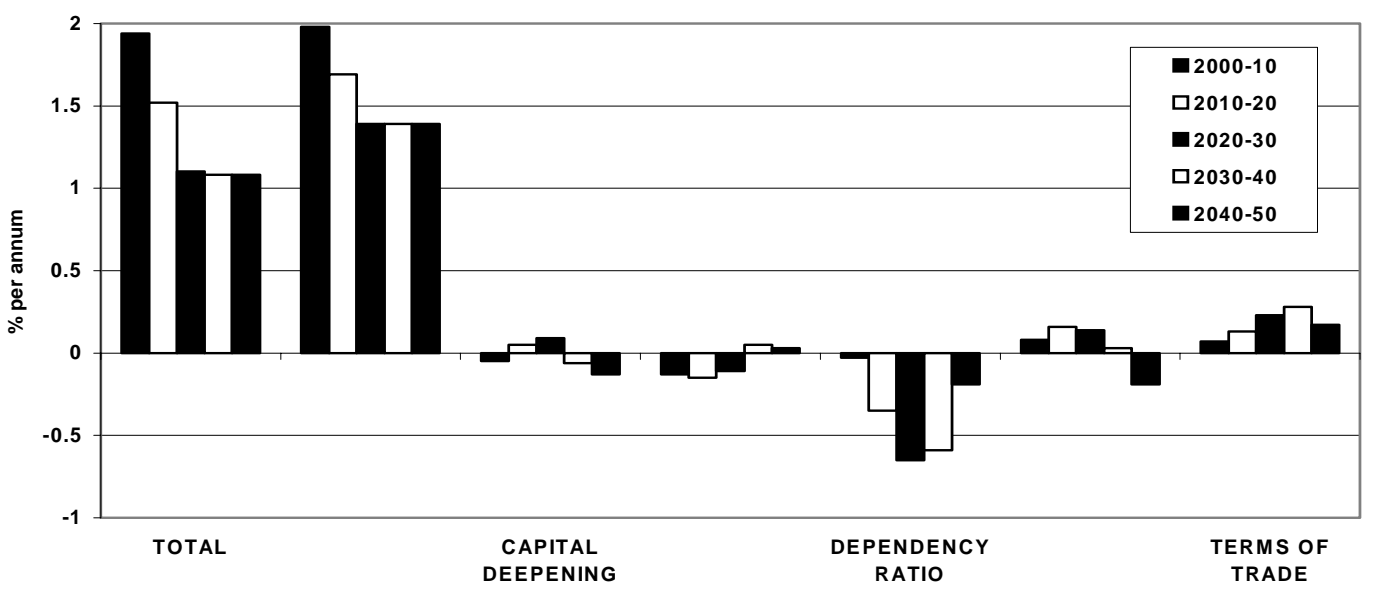

(c) United States

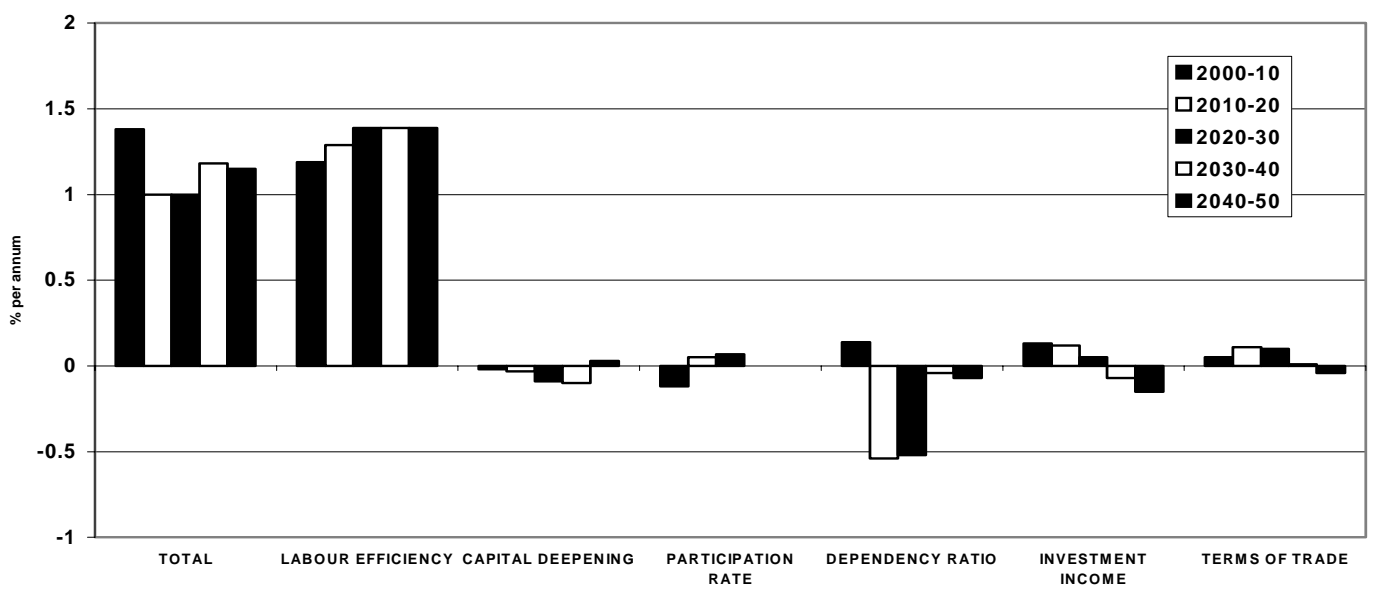

* Living Standards are measured as GNP per capita adjusted by the terms of trade (see text). 
Figure 11. Macroeconomic effects of an OECD-wide debt stabilisation(1) Difference from reference case

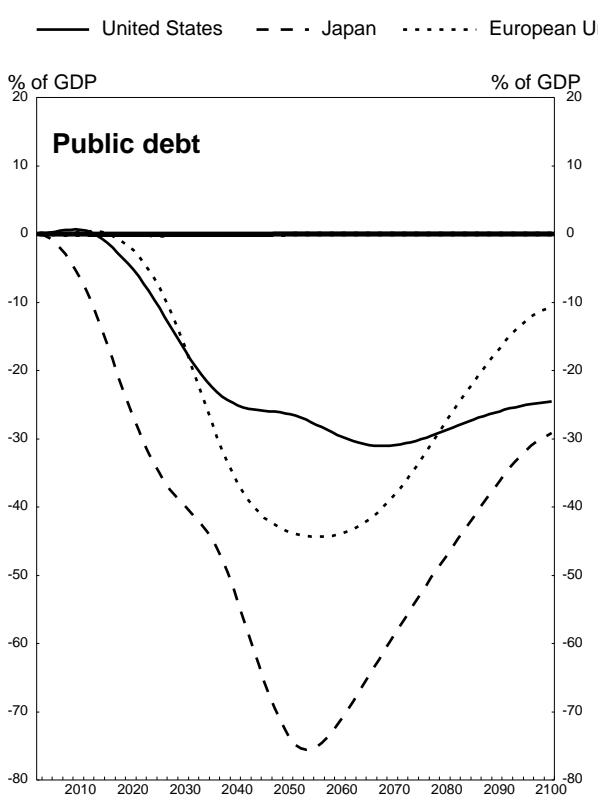

Other fast ageing countries $\quad \ldots$. Slow ageing countries
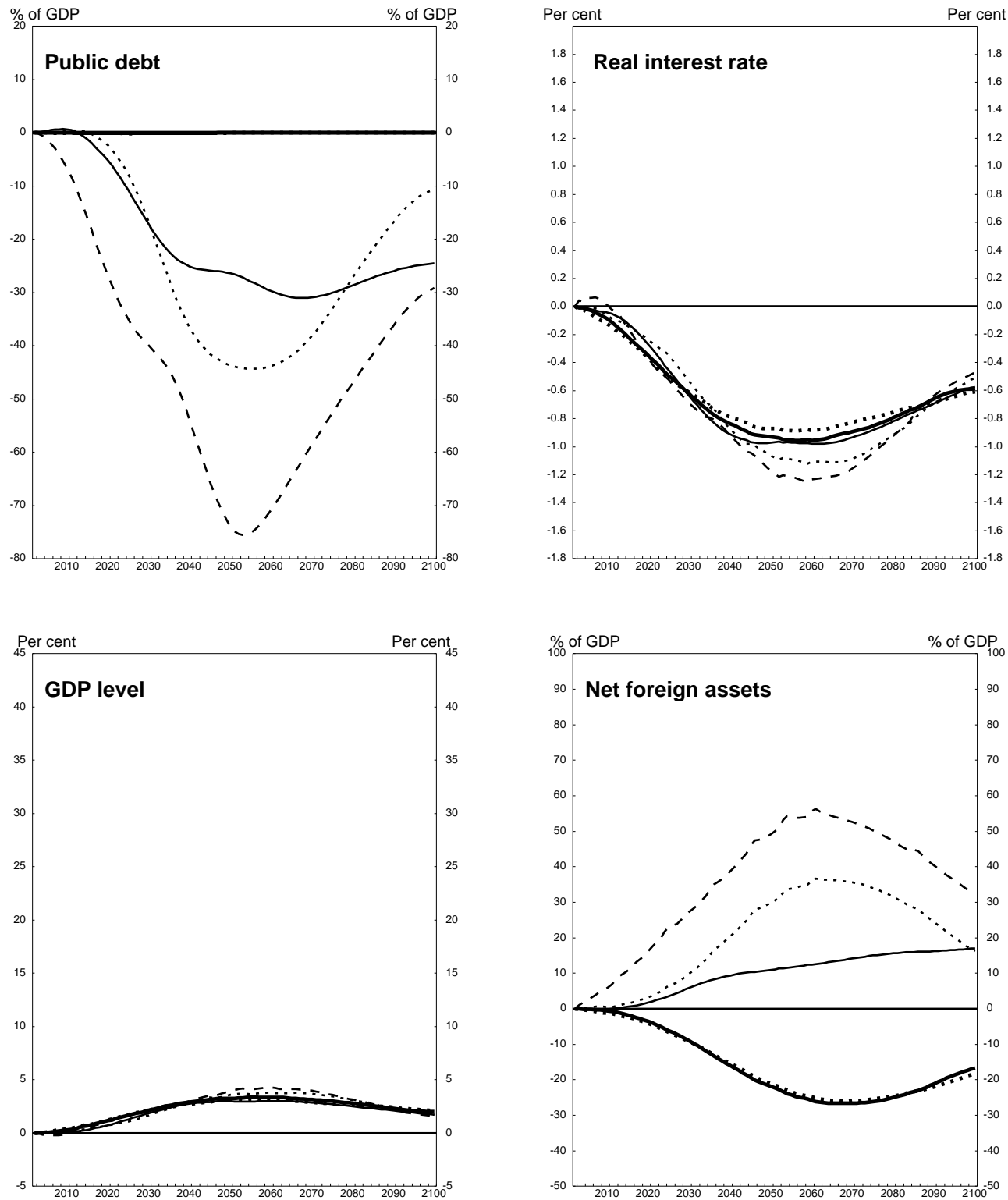

1. Government debt to GDP ratios are assumed to remain constant in the main OECD regions at their estimated level at the beginning of the projection period, with public expenditures increasing by only a $1 / 4$ of their increase in the reference scenario. 
Figure 12. Macroeconomic effects of debt stabilisation in Japan only(1) Difference from reference case

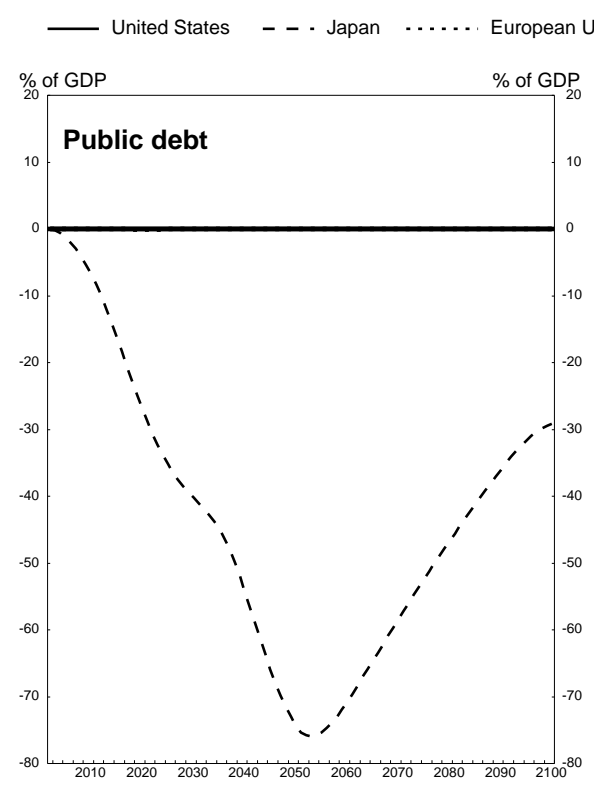

Other fast ageing countries $\quad \ldots$. ... Slow ageing countries
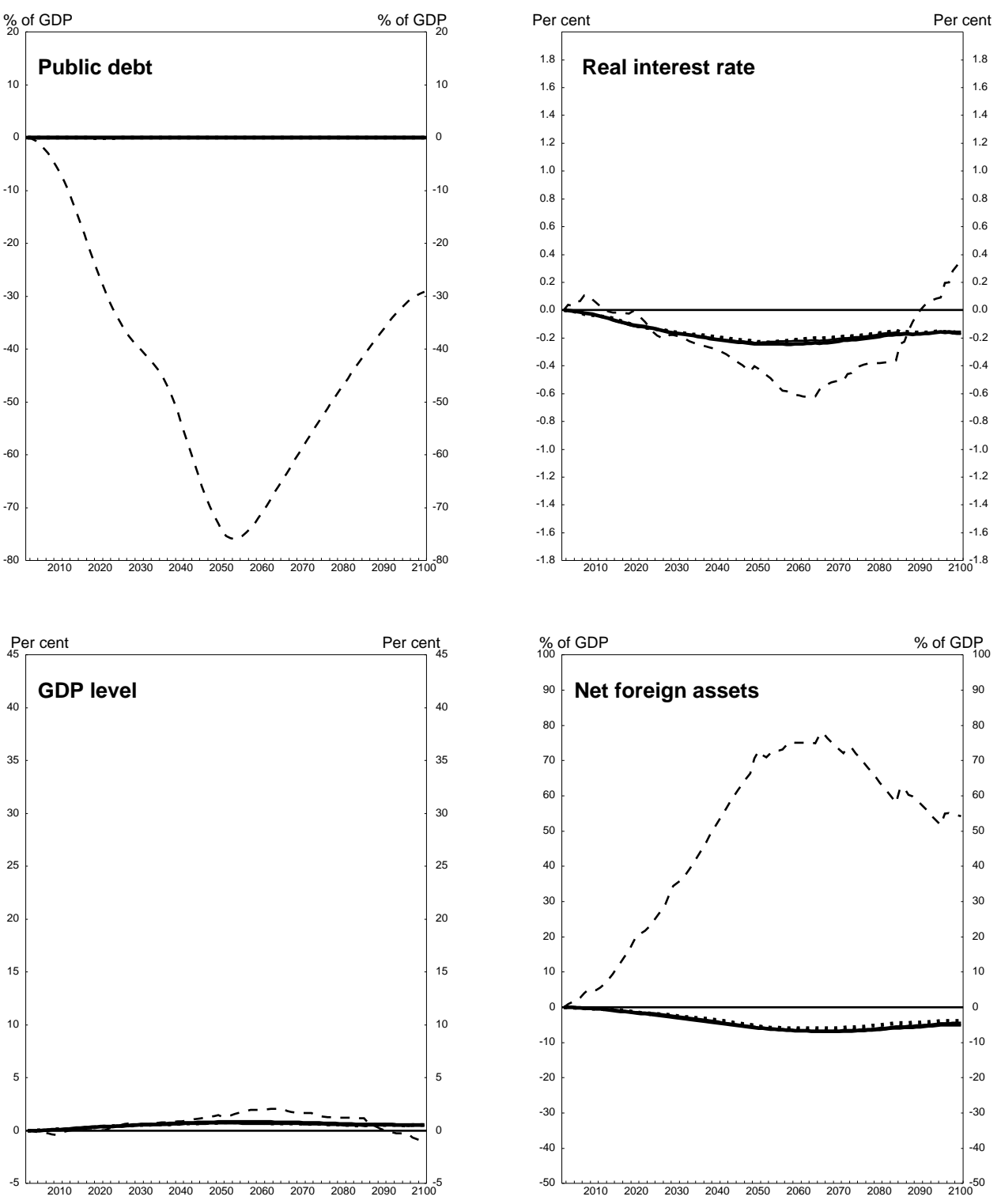

1. Government debt to GDP ratios and public expenditures as a proportion of GDP are assumed to remain constant at their estimated level at the beginning of the projection period in Japan only. 


\section{ECO/WKP(98)6}

Figure 13. Effect of public pension schemes on government financial balances (as a percentage of GDP)

\section{Japan}

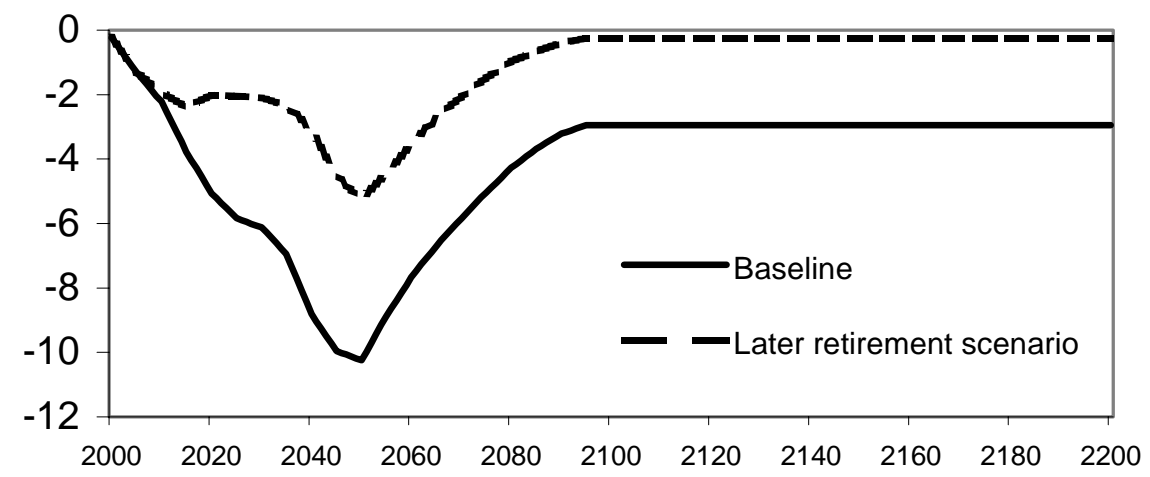

United States

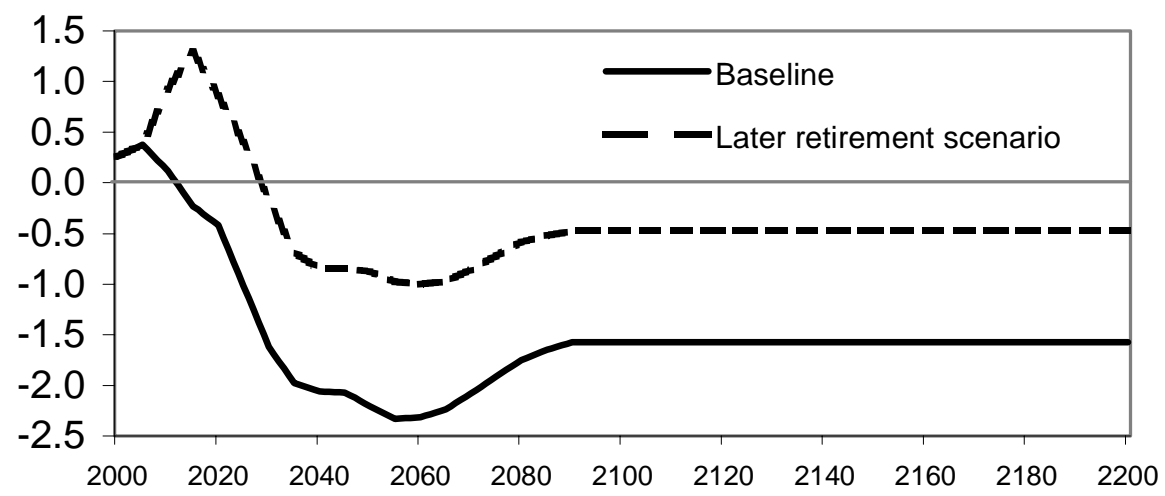

\section{European Union}

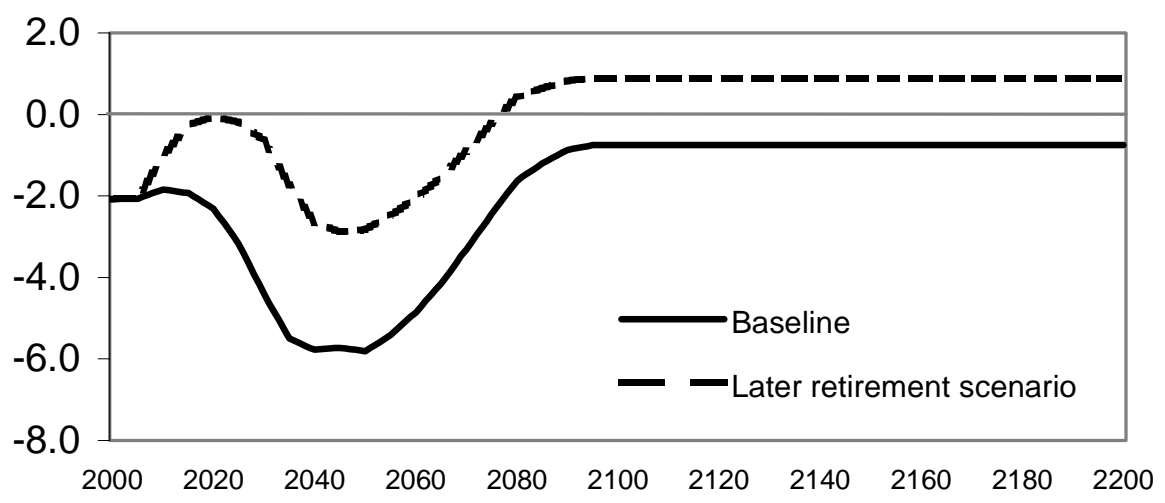


Figure 14. Increase in participation rates implied by the later

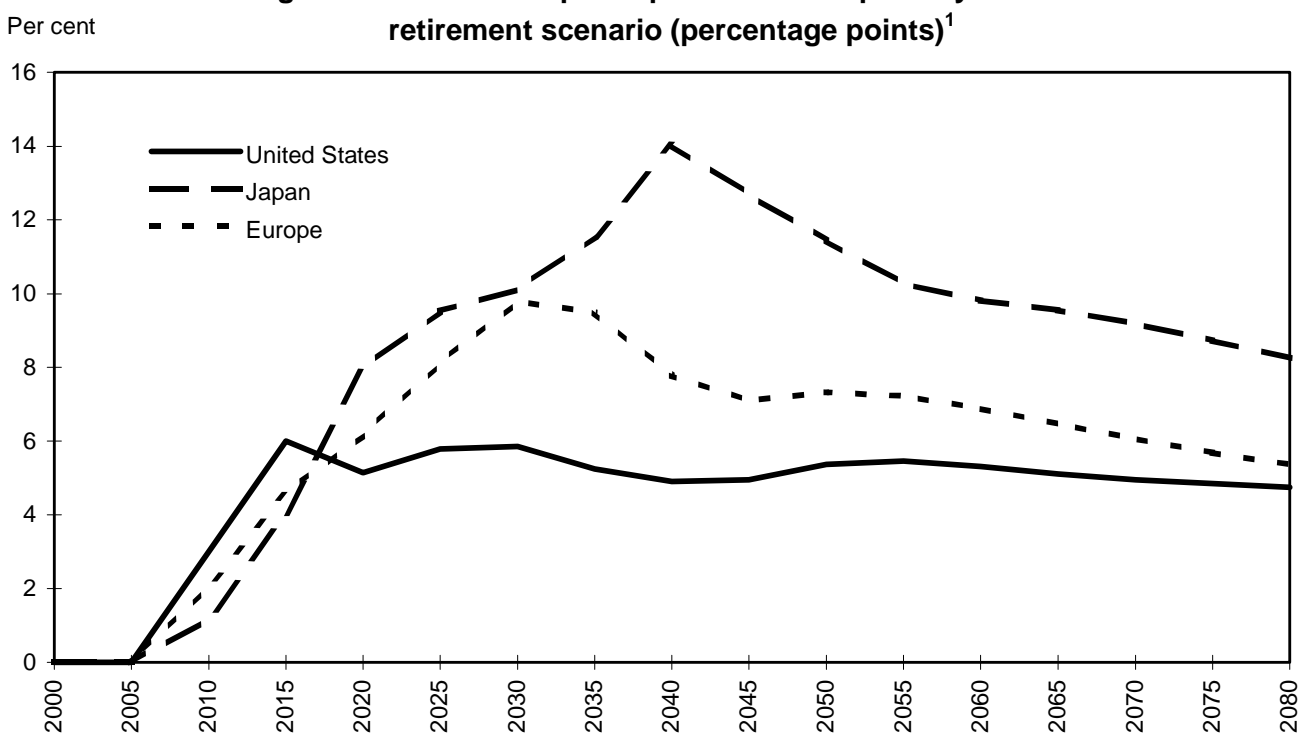

1. Percentage point changes in aggregate labour force participations rates, relative to the reference scenario. 
Figure 15. Macroeconomic effects of debt stabilisation with an increase in the retirement age(1) Difference from reference case
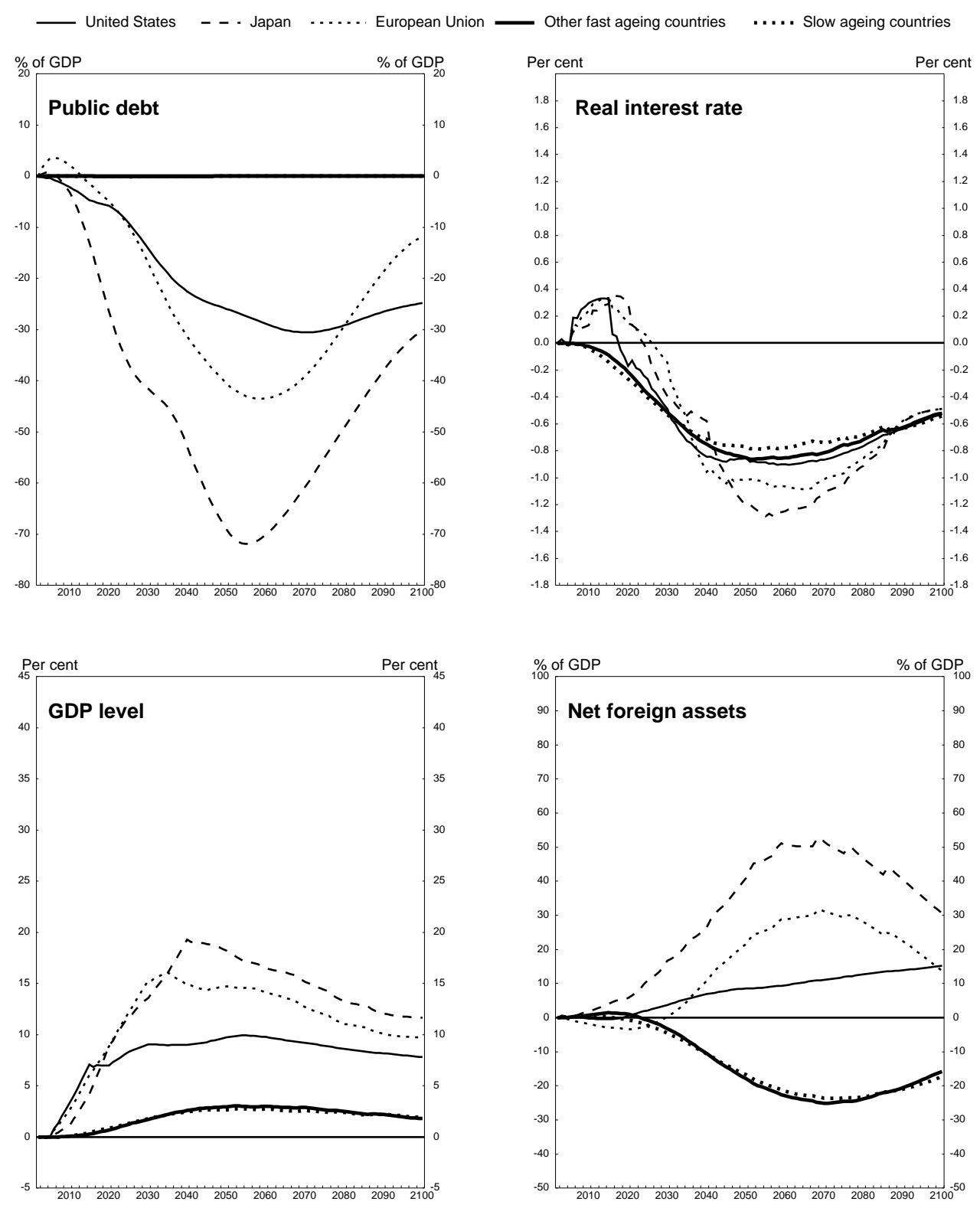

1. Retirement age is assumed to increase by 5 years to a maximun of 70 years in the main OECD regions (see table 7 for more details). Debt to GDP ratios are kept constant in the main OECD regions at their estimated level at the beginning of the projection period through reductions in expenditures. 
Figure 16. Macroeconomic effects of an increase in the retirement age with debt reduction in the US \& Europe(1)

Difference from reference case

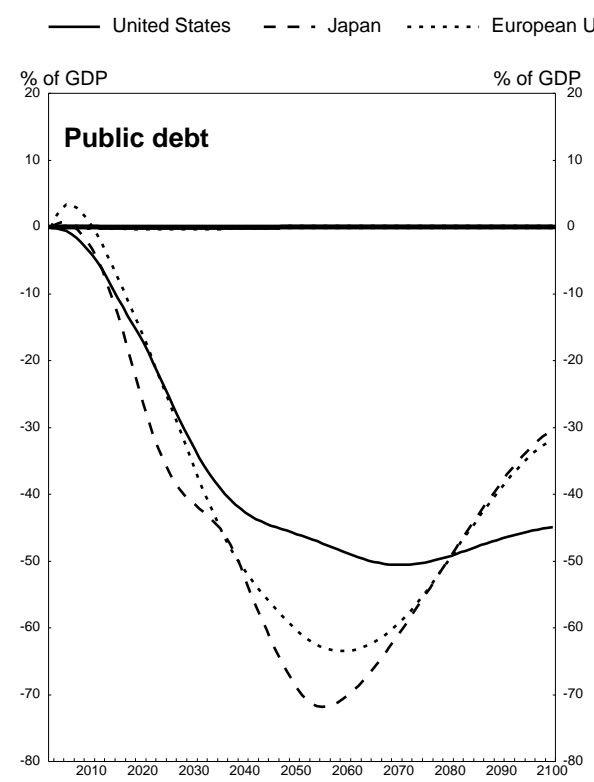

Other fast ageing countries $\quad \ldots .$. Slow ageing countries
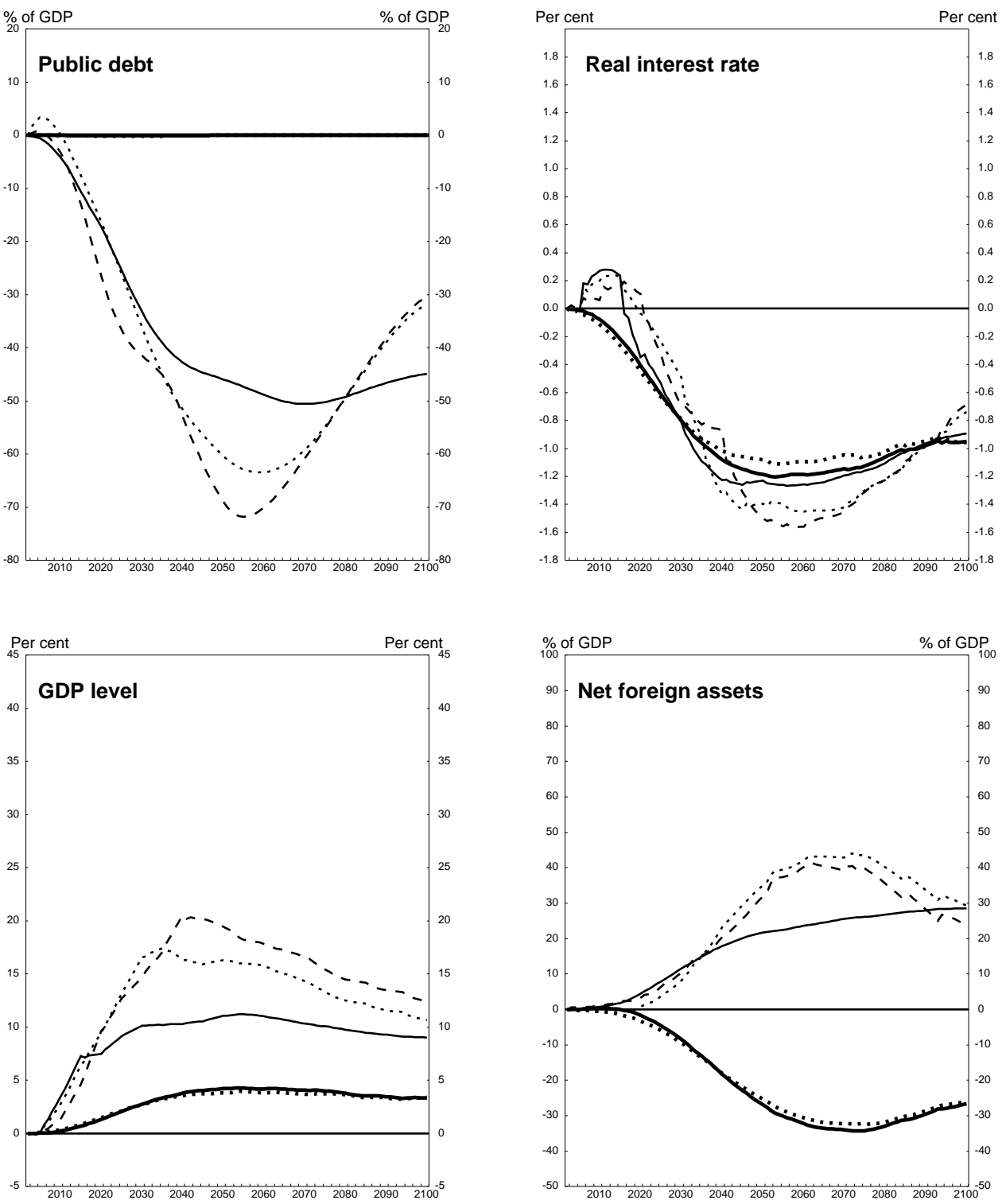

1. Retirement age is assumed to increase by 5 years to a maximun of 70 years in the main OECD regions (see table 7 for more details). Debt to GDP ratios are assumed to fall by 20 percentage points in the United State and the European Union between 2003 and the beginning of the projection period. 
Figure 18. Implications of alternative age-specific participation rates

Panel A. Participation by age (\%) in 1995

in the reference scenario

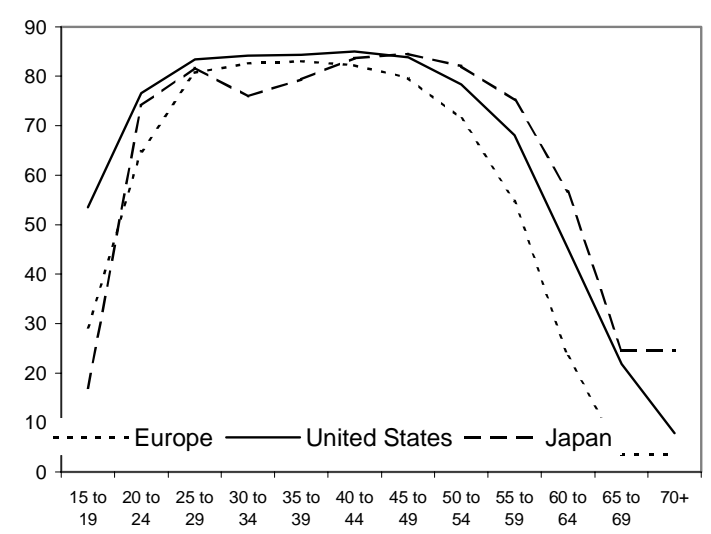

Panel B. Assumed participation by age after 2050 (\%) in the simulation

linear convergence between 2002 and 2050

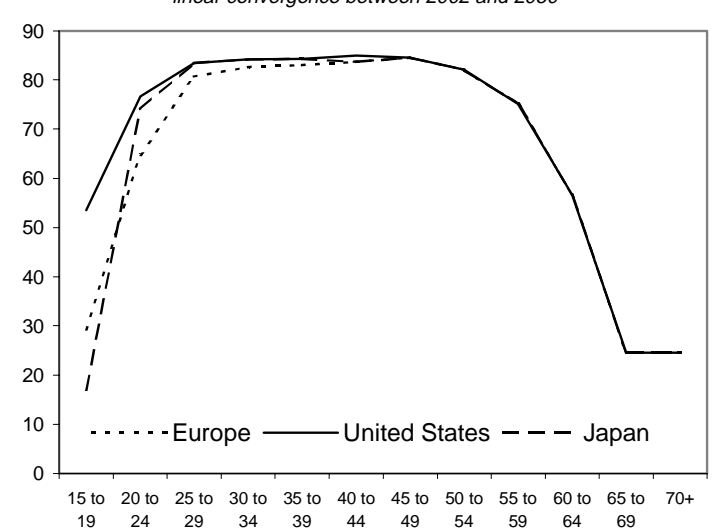

Panel C. United States - Aggregate participation rate (\%)

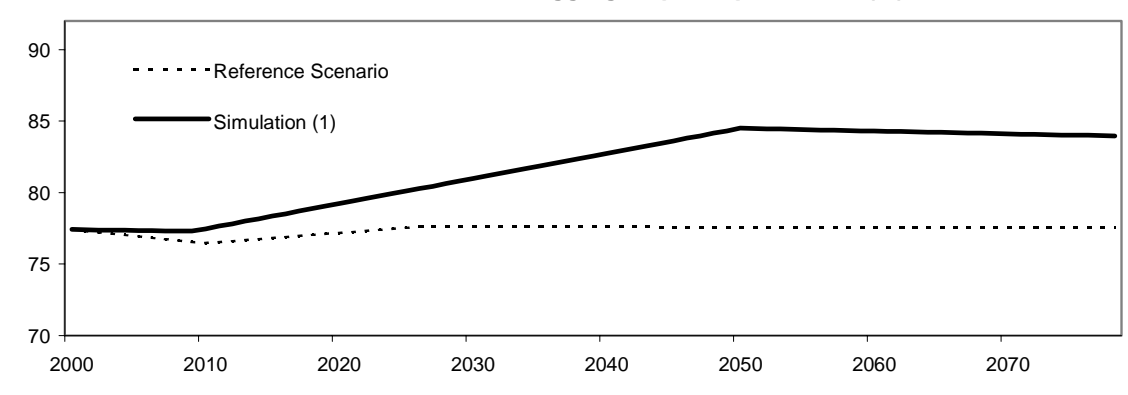

Panel D. Japon - Aggregate participation rate (\%)

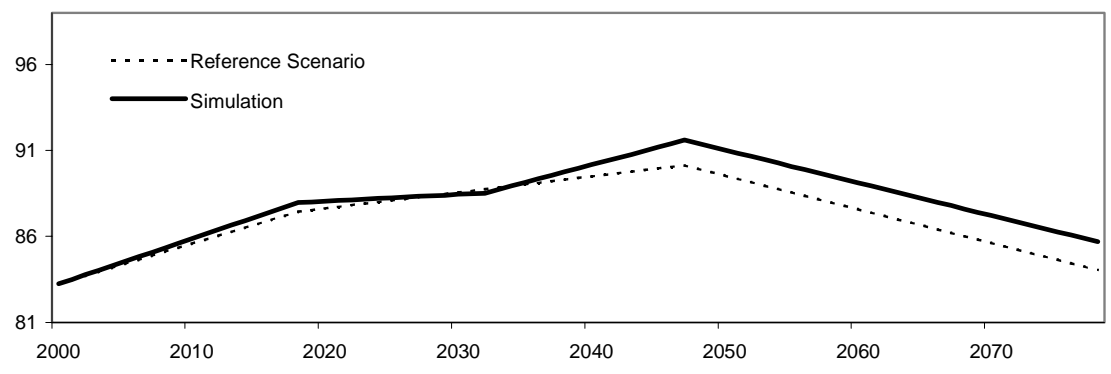

Panel E. Europe - Aggregate participation rate (\%)

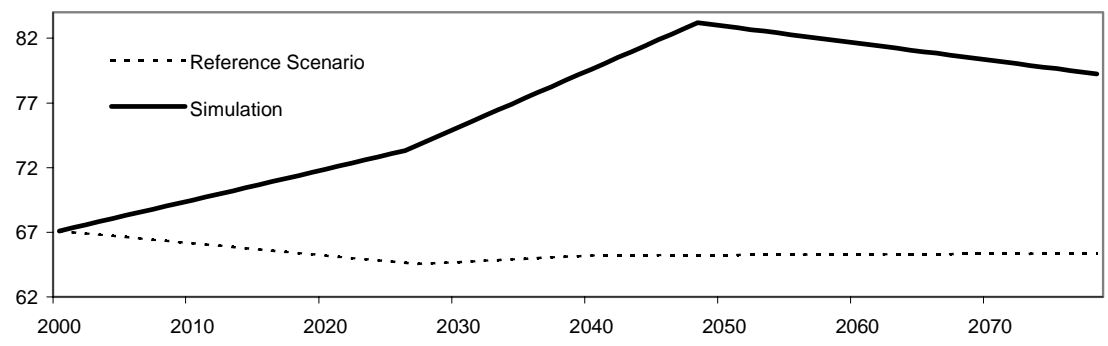

1. Assuming that participation rates by age change progressively from their 1995 levels to the structure shown in Panel B (see text for more details). 
Figure 17. Macroeconomic effects of debt stabilisation with an increase in the retirement age inplemented with a 10 year lag(1)

_ United States $\quad \ldots$ Japan $\quad \ldots .$. European Union $\quad$ Other fast ageing countries $\quad \ldots$... Slow ageing countries
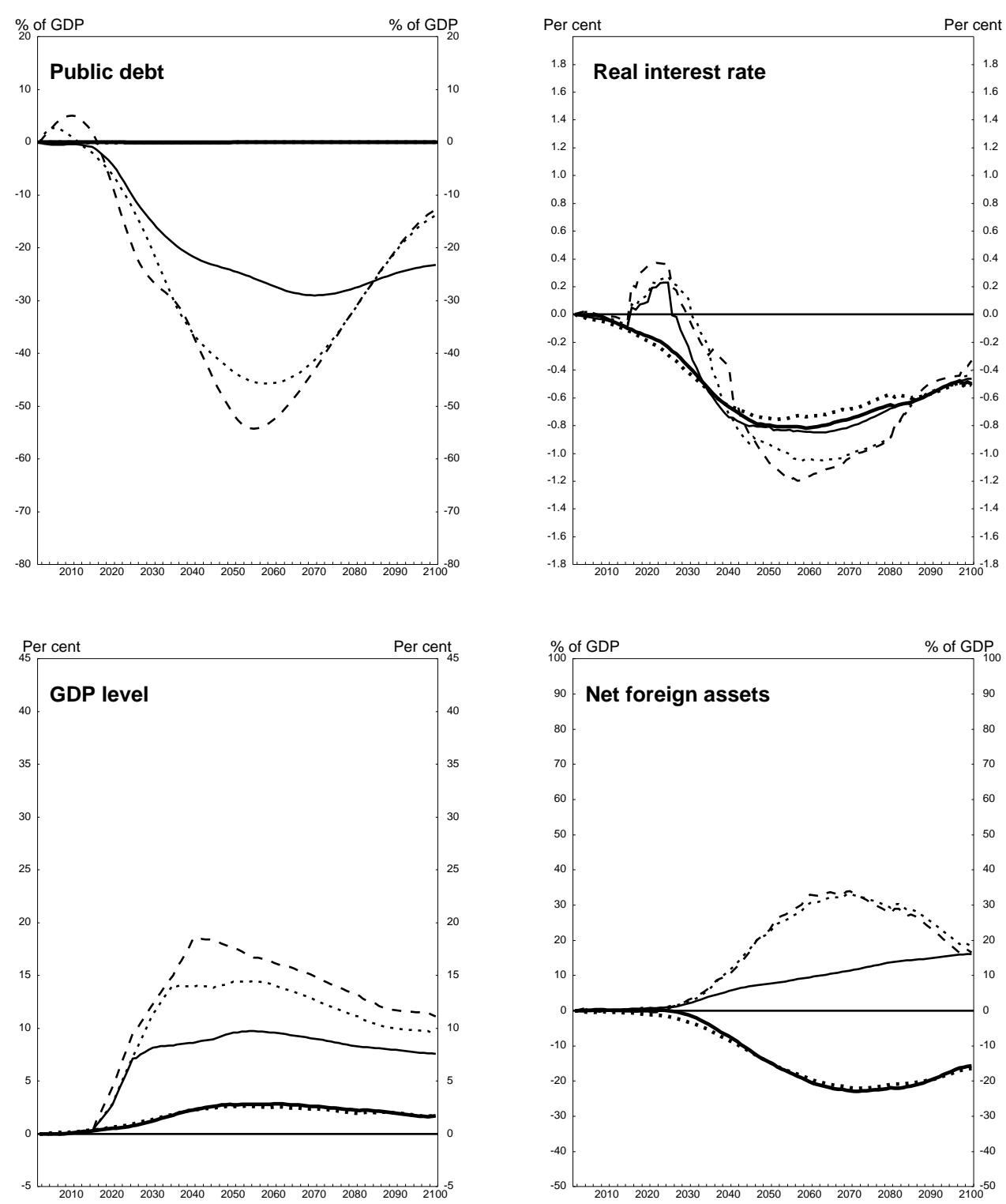

1. Reforms increasing the retirement age are assumed to be implemented with 10 years delay. Debt to GDP ratios are assumed to evolve broadly in line with the reference scenario until 2015 in the main OECD regions and to remain stable at that level thereafter. 
Figure 19. Macroeconomic effects of higher labour force participation rates and lower European Unemployment rate(1) Difference from reference case

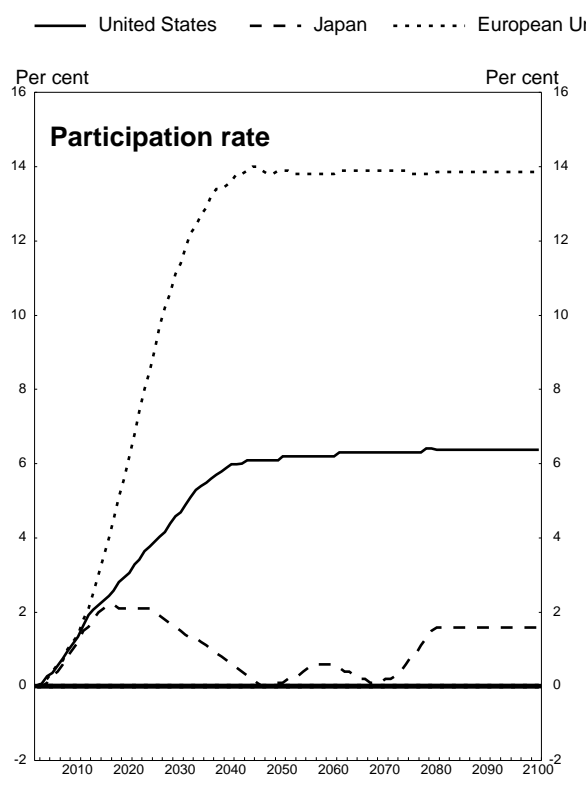

Other fast ageing countries $\quad \ldots$.... Slow ageing countries
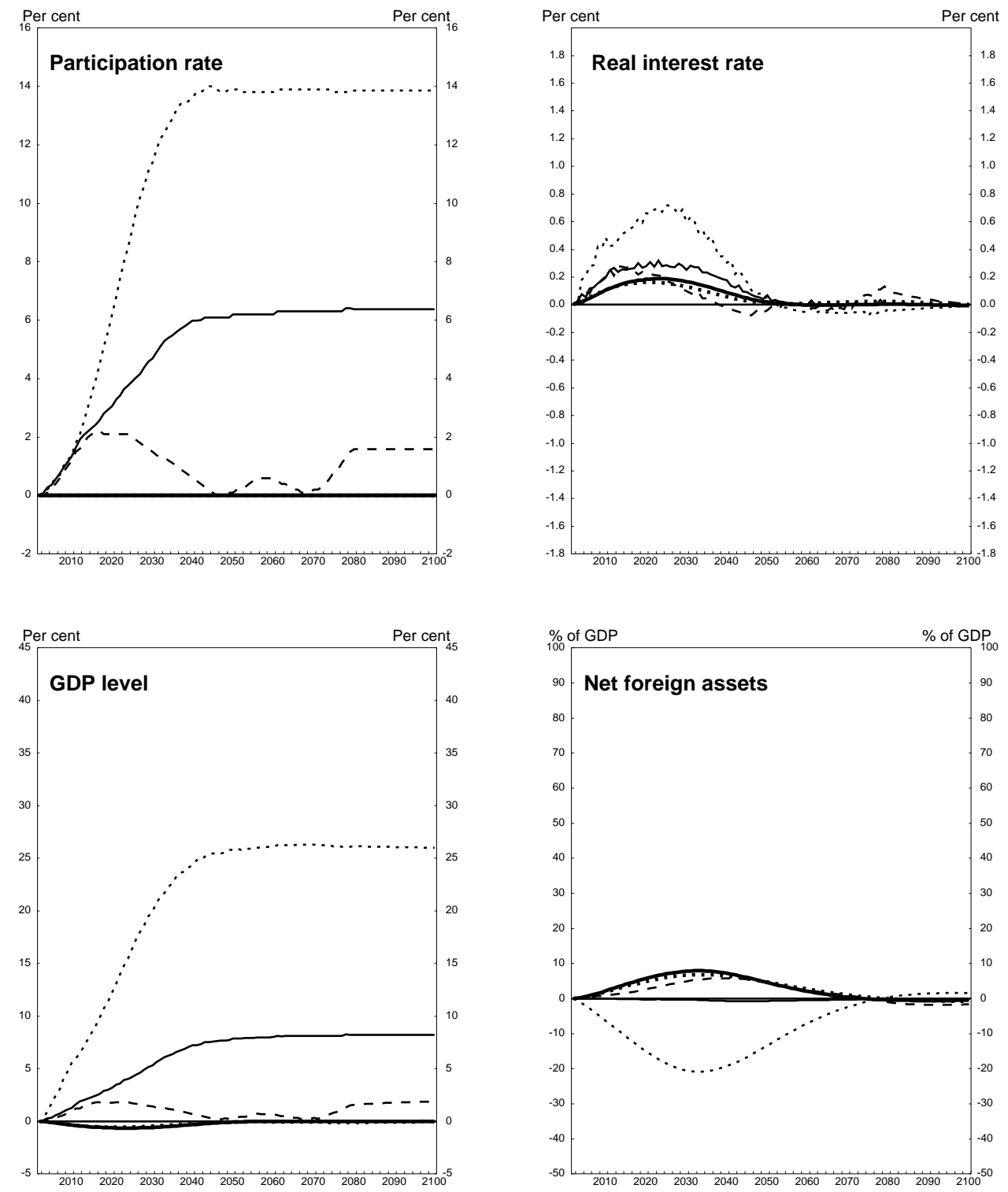

1. Participation rates for age groups 25-29 to 40-44 in Japan are assumed to increase to corresponding levels in the European Union and the United States. In the United States and the European Union participation rates of age group above 40 are to fall from 9.5 per cent to 5.5 per cent by 2010 . 
Figure 20. Macroeconomic effects of higher levels of total factor productivity(1) Difference from reference case

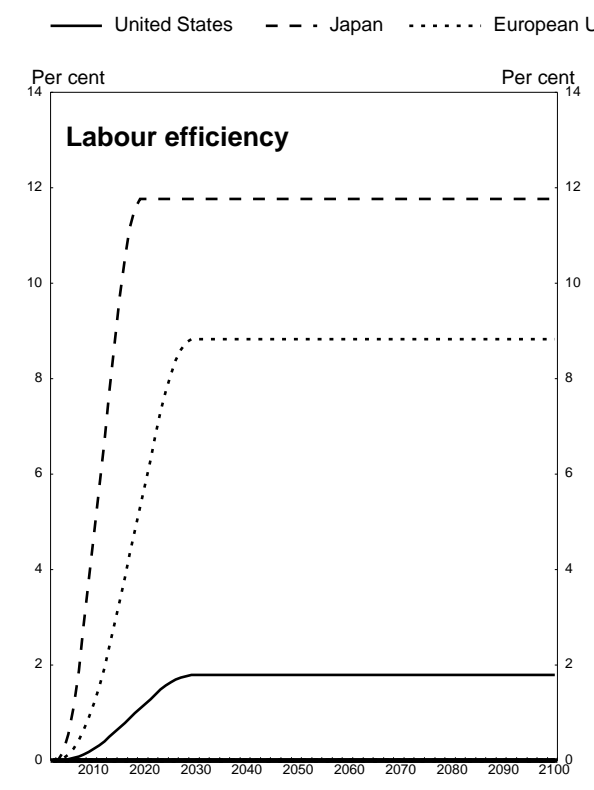

Other fast ageing countries $\quad \ldots$. ... Slow ageing countries
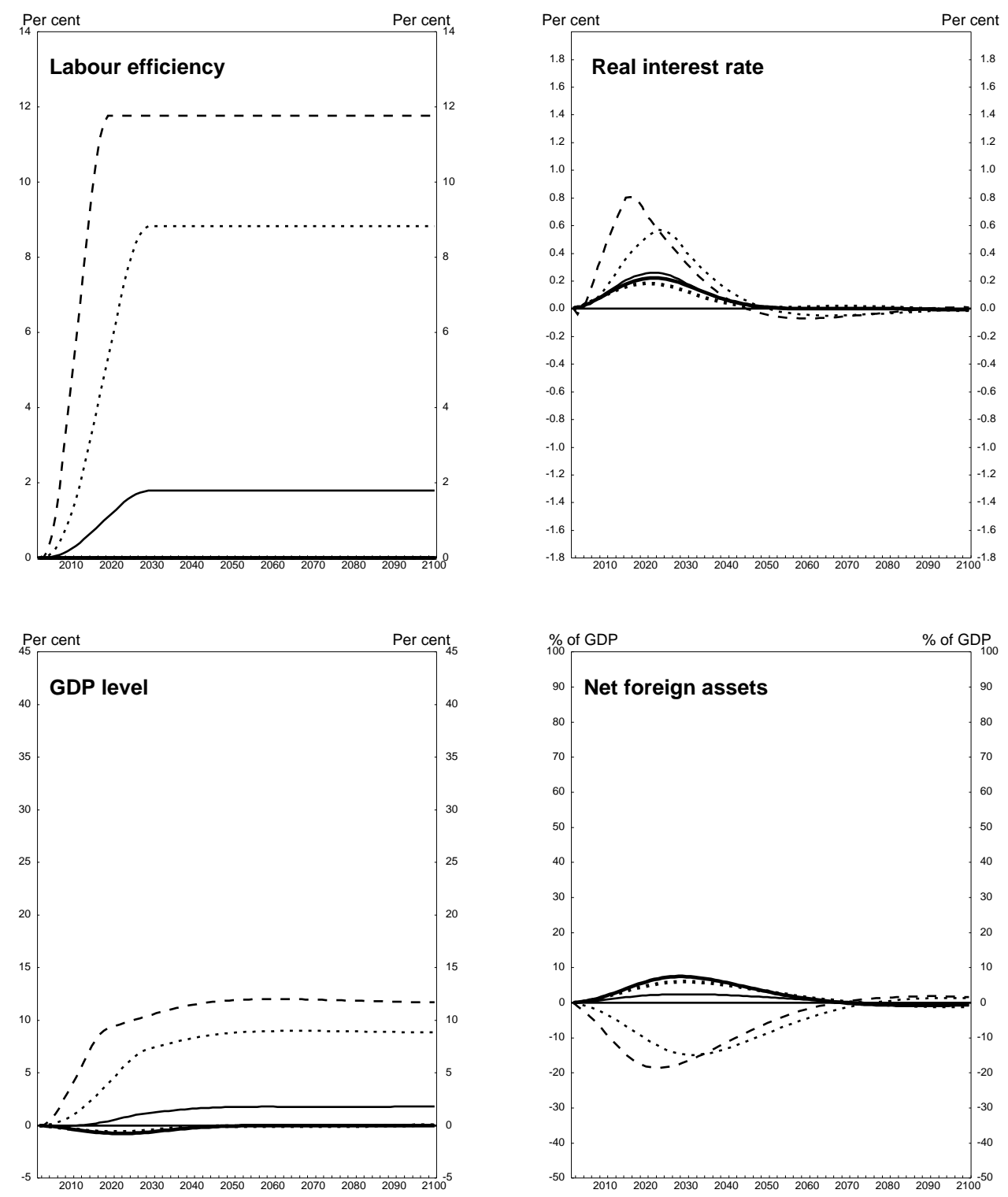

1. Labour efficiency levels are assumed to rise by 11.8 percent in Japan by 2020 and by 8.6 per cent in the European Union and 1.8 per cent in the United States by 2030 , relative to the reference scenario 
Figure 21. Macroeconomic effects of faster growth in the two mainly non-OECD regions Difference from reference case
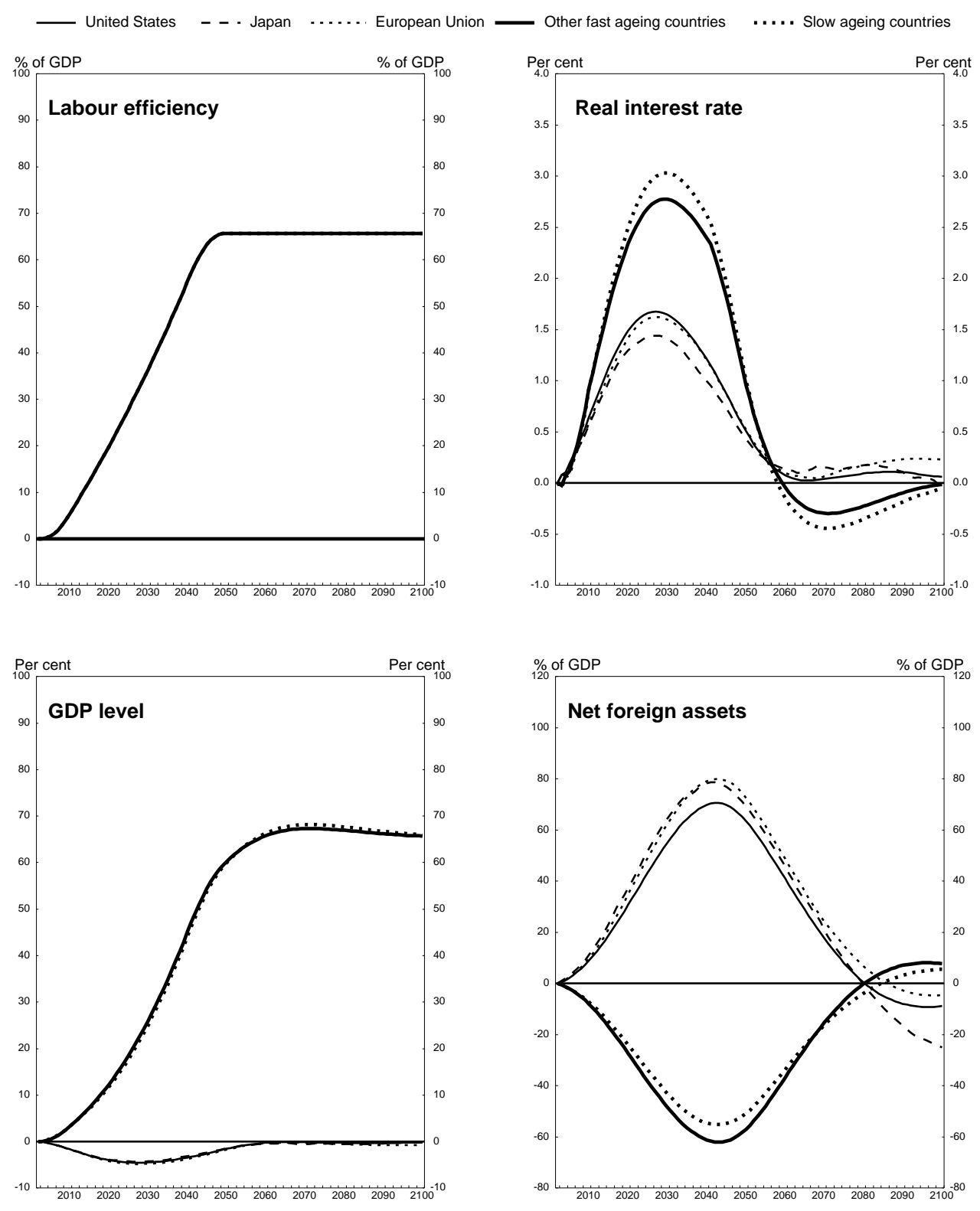

1. Labour efficiency is assumed to grow by an additional 1 point per annum in the two mainly non-OECD regions 
Figure 22. Macroeconomic effects of combined reforms(1) Difference from reference case
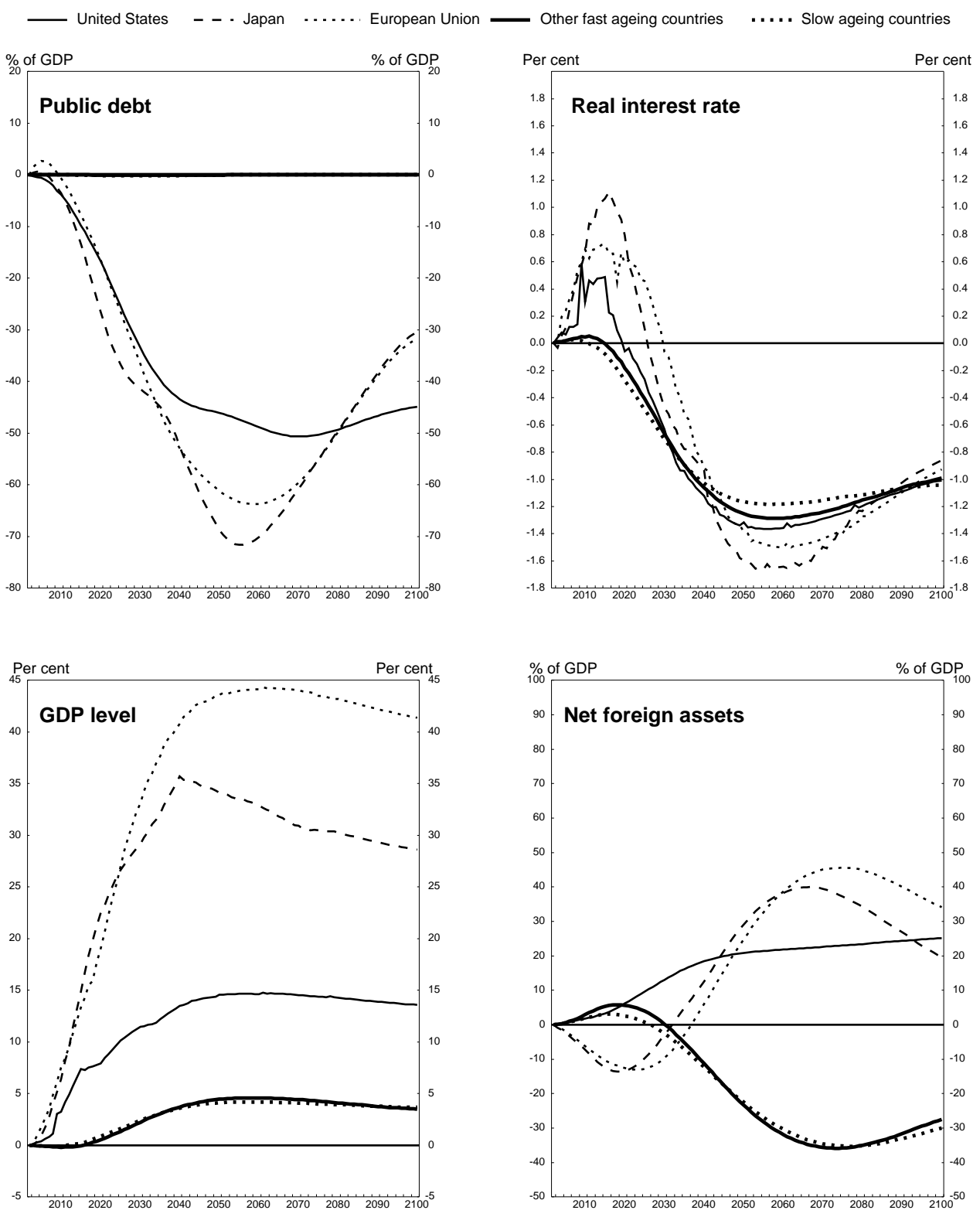

1. Combined reforms scenario as described in section 3.4 of the main text. 
Figure 23. Effects of combined reforms on living standards (difference relative from the reference scenario in per
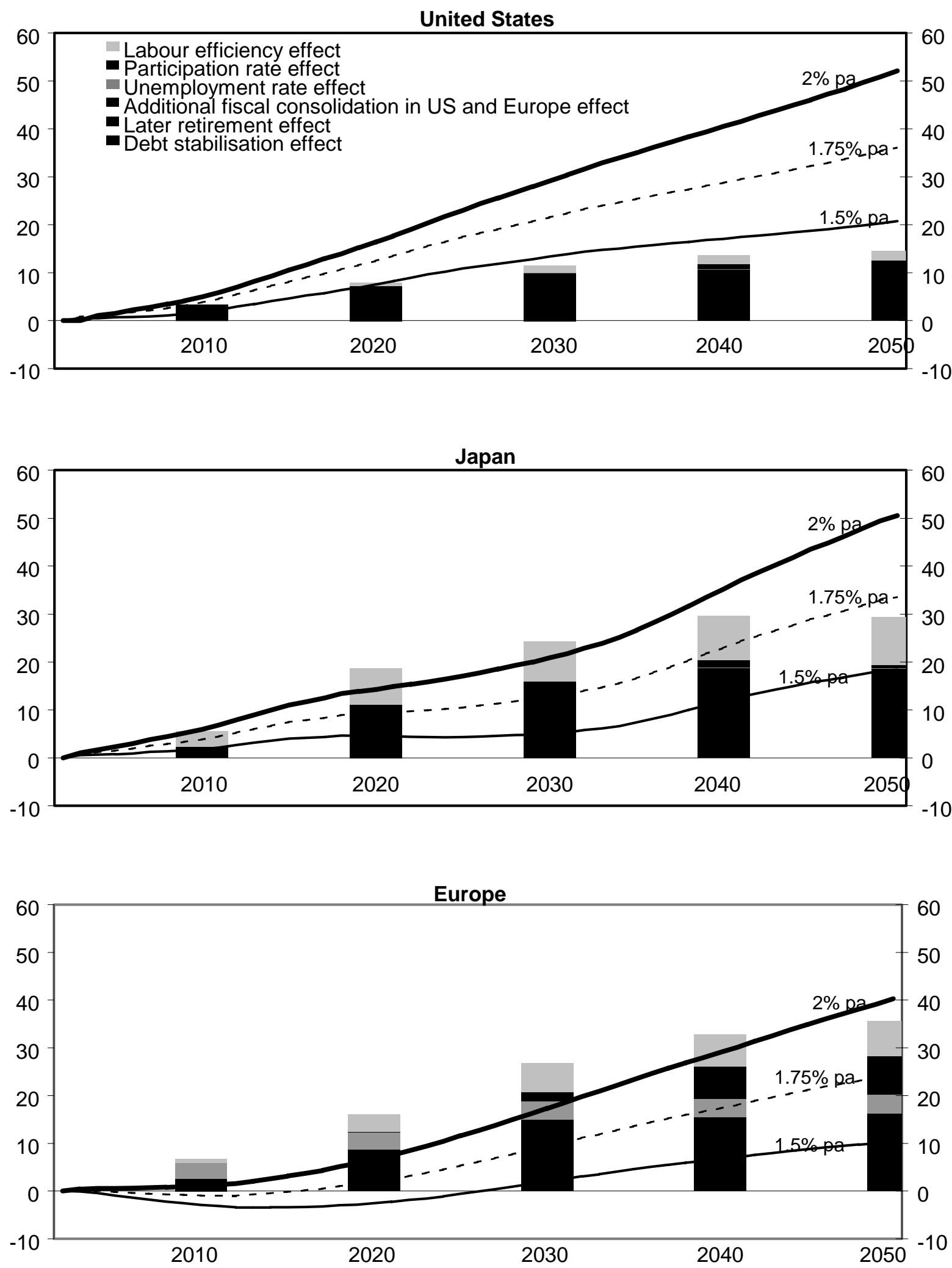


\section{TECHNICAL ANNEX}

\section{Summary description of the Minilink model and its properties}

112. Minilink is a structural dynamic model of the world economy designed to examine policy issues over a long-term horizon of fifty or more years. It comprises five regional blocs - for the United States, Japan, the European Union and the rest of the world, divided into fast- and slow-ageing regions - linked through international financial and goods market relationships. Each regional model comprises four sectors: production, government, consumption and external trade and investment. Agents in these sectors interact in goods and financial markets on the basis of dynamic optimisation principles, with optimal decisions being derived under general equilibrium conditions, subject to private and public inter-temporal budget constraints. Main features of the individual sectors are as described below, with key relationships summarised in Table A1.

\subsection{Consumption-saving sector}

113. The choice of the consumption-saving model is based on the requirements of capturing the influences of demographic changes on aggregate savings, while remaining sufficiently simple to be tractable in a general-equilibrium, multi-region model framework. Whilst an OLG approach (as popularised by Auerbach and Kotlikoff [1987]) allows for age-related heterogeneity and, hence, the influence of demographic change on aggregate savings, such models tend to underestimate the savings rates of older generations, and thereby overestimate the implications of ageing on global savings (see Borsch-Supan, 1996) ${ }^{71}$.

114. For this reason, the approach taken in Minilink is based on a modified version of the Blanchard model of consumption [see Blanchard (1985)]; one in which labour income varies with age, consumers face liquidity constraints and the probability of death is explicitly related to demographic developments ${ }^{72}$. Following Faruquee, Laxton and Symansky (1997), a key departure from the Blanchard model is that instead of growing continuously over time, the path for labour income is assumed to be a function of aggregate income characterised by a hump-shaped distribution:

$$
y_{s, t}=\left(a_{1} e^{-\alpha_{1}(t-s)}+a_{2} e^{-\alpha_{2}(t-s)}\right) \cdot \alpha Y_{s, t}
$$

where $y_{s, t}$ denotes individual labour income at time $\mathrm{t}$ of the cohort of consumers born at time s, $\alpha$ is the share of labour in total income $Y_{t}, e$ denotes an exponential function, and $a_{1}, a_{2}, \alpha_{1}$ and $\alpha_{2}$ are parameters whose values determine the shape of the individual income profile ${ }^{73}$. With such a distribution,

71. Although this deficiency can be alleviated by the joint introduction of bequests and uncertainty regarding life expectancy, such modifications render OLG models intractable in a multi-region framework and as a result there appear to be no international applications of the OLG approach.

72. A major drawback of Blanchard's original model is the assumption that each consumer faces a constant probability of death regardless of age, which loses important life-cycle effects.

73. The link between the parameters is such that if $\alpha_{1}, \alpha_{2}$ and $a_{1}$ are set to zero and $a_{2}$ is equal to one, the model collapses to the basic case of constant labour income growth over time. 


\section{$\mathrm{ECO} / \mathrm{WKP}(98) 6$}

individual labour income is assumed to be initially low and, given that consumers start out with no financial assets, they need to borrow against future earnings in order to enjoy higher levels of consumption. This feature allows for the introduction of a market imperfection whereby consumers are initially denied access to credit and therefore constrained to consume labour income until it is sufficient to meet the desired level of consumption ${ }^{74}$. Thus, a second extension is that, a fixed proportion of consumers $(\lambda)$ are assumed to be constrained to consume no more than their current income:

$$
c_{s, t}=\left(1-\tau_{s, t}\right) \cdot y_{s, t}
$$

where $c_{s, t}$ is the consumption at time t of generation born at time $s$ and $\tau$ is the tax rate on labour income. Consumers who are not liquidity constrained are nonetheless constrained by their lifetime income, but are free to accumulate or de-cumulate savings according to the following intertemporal budget constraint:

$$
\Delta f w_{s, t}=\left(R_{t}+\rho\right) f w_{s, t-1}+\left(1-\tau_{s, t}\right) y_{s, t}-c_{s, t_{t}}
$$

where $f w$ represents for financial wealth and $R$ is the real return on assets.

115. Solving the consumer choice problem under these conditions and aggregating across individual agents yields the following set of steady-state relationships ${ }^{75}$ :

$$
\begin{gathered}
C_{t}=\left(\Omega_{t} T W_{t}+\left(\beta \lambda_{1}+(1-\beta) \lambda_{2}\right)[Y-T]\right) \cdot P_{t} / P C_{t} \\
\left.T W_{t}=F W_{t}+\beta\left(1-\lambda_{1}\right) H W_{1, t}+(1-\beta)\left(1-\lambda_{2}\right) H W_{2, t}\right) \\
H W_{i}=\frac{\left((1-\tau) \alpha \cdot Y_{t}+T R F_{t}+r i s k \cdot K_{t}\right)}{R_{t}+\rho_{t}-z_{t}+\alpha_{i}}, \quad i=1,2 \\
F W_{t}=K_{t}+B_{t}+N F A_{t} \\
P C_{t}=\left(1-w^{f}\right) P_{t}+w^{f} \cdot P M_{t} \\
\Omega_{t}=(\gamma-1 / \gamma) \cdot R_{t}+\rho_{t}+(\phi / \gamma) \\
\rho_{t}=\Lambda_{0}+\Lambda_{1} \cdot\left(O L D D E P_{1}-O L D D E P_{\text {base }}\right)
\end{gathered}
$$

116. Total consumption, expressed as a weighted-sum over two broad categories of consumers (distinguished on the basis of whether or not they are liquidity-constrained), is a direct function of the stock of total wealth, current disposable income and the relative price of consumption goods

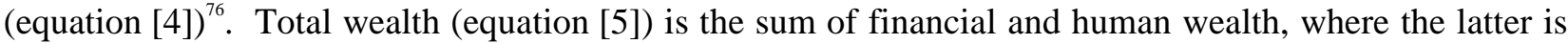
the weighted sum of two terms corresponding to the two components of labour income. Each component

74. In the basic Blanchard model, consumption is always lower than either income or financial wealth which rules out the possibility of liquidity constraints.

75. For a more detailed derivation, see Faruquee et al. (op cit.).

76. The parameters $\beta, \lambda_{1}$ and $\lambda_{2}$ are given by: $\beta=a_{1} \rho /\left(\rho+\alpha_{1}\right) ; \lambda_{1}=1-\exp \left(-\alpha_{1} t\right) ; \lambda_{2}=1-\exp \left(-\alpha_{2} t\right)$. 
of human wealth is the present value of future after-tax labour income to consumers (equation [6]). Financial wealth (equation [7]) comprises claims on domestic capital $K_{t}$ and government bonds $B_{t}$, and on net foreign assets $\left(N F A_{t}\right)$. The price of consumption goods (equation [8]) is a weighted average of the domestic price $P_{t}$ and the import price $P M_{t}$. The propensity to consume out of wealth $\Omega_{t}$ depends on the probability of death $(\rho)$, the rate of time preference $(\phi)$, the intertemporal elasticity of substitution $(1 / \gamma)$ and the real interest rate (equation [9]). Finally, as a further extension of the Blanchard model, the probability of death is endogenised as a function of the old-age dependency ratio (equation [10]).

\subsection{Production sector}

117. The production technology is characterised by a two-factor constant-returns-to-scale Cobb-Douglas function:

$$
Y_{t}=K_{t}^{1-\alpha} \cdot(L \cdot E L E F)_{t}^{\alpha}
$$

where $Y_{t}$ is real output, $K_{t}$ is the aggregate capital stock, $L_{t}$ is the number of employees, $E L E F_{t}$ is the index of labour efficiency, and $\alpha$ is the share of labour in total income.

Under standard conditions of profit maximisation, the marginal product of capital is related to the real interest rate as follows;

$$
\frac{K_{t}}{Y_{t}}=\frac{(1-\alpha)}{\left(R_{t}+r i s k-\delta\right)}
$$

where $R_{t}$ is the real interest rate, risk is the equity-risk premium and $\delta$ is the rate of capital depreciation. The employed labour force is determined by assumptions regarding the dependency ratio, the natural rate of unemployment, the participation rate and population. For a stable interest rate (and therefore a stable capital output-ratio) long-run growth is ultimately determined by growth rates of population and labour efficiency which are both set exogenously.

\subsection{Government sector}

118. The government is assumed to raise taxes on labour income in order to purchase consumable goods and/or make lump-sum transfers to households for social benefit purposes. For simplicity, the government is assumed to make no direct contribution to production or to the stock of capital. It can run a fiscal deficit and cumulate debt, but faces a budget constraint whereby current government expenditures $\left(G C_{t}\right)$, transfers $\left(T R F_{t}\right)$ and interest payments on public debt, must be financed by taxes $\left(T A X_{t}\right)$ and/or new bond issues $\left(B_{t}\right)$, where $i_{t}$ is the nominal interest rate.

$$
T A X_{t}=G C_{t}+T R F_{t}+i_{t} B_{t-1}-\left(B_{t}-B_{t-1}\right)
$$




\section{ECO/WKP(98)6}

Dividing each term in [13] by nominal output $\left(Y_{t} P_{t}\right)$ and expressing in terms of government bonds, yields the following identity for the accumulation of public debt as a share of output over time ${ }^{77}$, where $\mathrm{R}_{t}$ is the real interest rate:

$$
b_{t}=\frac{\left(1+R_{t}\right)}{\left(1+g_{t}\right)} \cdot b_{t-1}+g c_{t}+t r f_{t}-\tau_{t}
$$

119. Government transfers are introduced so as to allow for the explicit treatment of public pensions $^{78}$. Two further components of government consumption expenditures explicitly identified as being sensitive to demographic factors are those on health and education. In both cases, it is assumed that the cost per capita rises in line with the real wage and hence economy-wide labour productivity $(P D T Y)^{79}$. Changes in education expenditures $\left(E D U C_{t}\right)$ relative to a base year are assumed also to be proportional to the change in the population aged less than 15 years old $\left(Y O U N G_{t}\right)$.

$$
E D U C_{t} / E D U C_{\text {base }}=\left(Y_{\text {OUNG }} / \text { YOUNG }_{\text {base }}\right) *\left(P D T Y_{t} / P D T Y_{\text {base }}\right)
$$

where the subscript "base" denotes the value in the base year.

120. Public expenditures on health are modelled in a similar fashion. However, an adjustment is made to allow for costs for people above 65 years of age being on average several times larger than those for other age categories. Changes in age-adjusted health spendings per capita $\left(H P C A P A D J_{t}\right)$ relative to a base year are thus assumed to rise in line with real wages i.e. the change in economy-wide labour productivity, as follows:

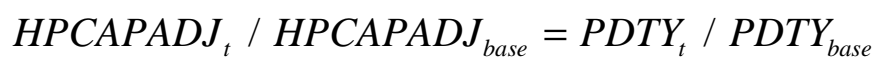

where age-adjusted health costs per capita are calculated as a weighted sum of the costs per capita for old-age people and for the rest of population $\left(H P C A P_{t}\right)$ :

$$
\text { HPCAPADJ }_{t}=\text { HPCAP }_{t} \cdot[(R A T I O \cdot A G E D)+(1-A G E D)]
$$

and $R A T I O$ is the cost for old-age people relative to the rest of population, and $A G E D$ is the share of total population older than 65 .

121. While government debt as a proportion of GDP is set as an exogenous target in the long run, it is allowed to deviate from target in the short run. The government sector is thus completed with a fiscal reaction function whereby the tax rate adjusts to gradually close the gap between the current debt and its long-run target (where $d_{1}, d_{2}$ are adjustment parameters) ${ }^{80}$ :

77. Lower case letters are used to denote variables expressed as shares of output.

78. Section 3 of this Annex provides more details on the assumptions made regarding transfers and the effects of ageing on pensions incorporated in the reference scenario.

79. A large share of expenditures on education and health is on salaries which are assumed to rise in line with labour productivity.

80. The fiscal reaction function is similar to that used in Bryant (1996b). The determination of the target debt ratio for the reference scenario is described in section 4 of this Annex. 


$$
\tau_{t}=\tau_{t-1}+d_{1} \cdot\left(b_{t}-\bar{b}_{t}\right)+d_{2} \cdot\left(b_{t}-b_{t-1}\right)
$$

\subsection{External sector}

122. The external sector is based on the Armington (1969) framework, with each region assumed to produce a single good which is an imperfect substitute for those of other regions. The export price in each region is set equal to the domestic production price. The import price $P M_{t}$, which is determined relative to base year, is a weighted average of foreign export prices, with weights based on a trade share matrix representing each region's export shares (in value terms) in other regions' import market in the base year:

$$
P M_{i, t} / P M_{i, b a s e}=\sum_{j} \frac{x_{j, i}}{\text { mtot }_{i}} \cdot \frac{P_{j, t}}{P_{j, b a s e}}
$$

where $x_{j, i}$ is the value of exports of region $j$ to region $i$ and mtot $_{i}$ represents total imports of region $i$ in the base year. While real bilateral exchange rates are simply the relative price between the goods of any two regions, the real effective exchange rate is measured as a ratio of export prices to competitor prices:

$$
\frac{R X R_{i, t}}{R X R_{i, \text { base }}}=\frac{P_{i, t}}{P_{i, b a s e}}-\sum_{e=1}^{5}\left(\sum_{j \neq i} \frac{x_{i, j}}{x_{\text {tot }}} \cdot \frac{x_{e, j}}{\text { mtot }_{j}}\right) \cdot \frac{P_{i, t}}{P_{i, \text { base }}}
$$

where $x$ tot $_{i}$ is total exports to region $i$. Competitor export prices are double weighted: on the basis of the relative importance of individual competitors in each market and the relative importance of individual markets to each region's exports.

123. International trade, assumed to take place only in consumption goods, is determined according to a two-step procedure. Import volumes are first determined by a demand effect (dependent on private consumption with a unit elasticity) and a relative price effect (the ratio of import to production prices) expressed in rates of change:

$$
\frac{M V_{i, t}}{M V_{i, \text { base }}}=\frac{c_{i, t}}{c_{i, \text { base }}}+\theta_{i} L O G \frac{\left(P_{i, t} / P M_{i, t}\right)}{\left(P_{i, \text { base }} / P M_{i, \text { base }}\right)}
$$

where $M V_{i, t}$ is the import volume of region $i$ and $\theta_{i}$ is the import price elasticity. In the second step import demands are allocated between regions through a set of export share equations as a function of competitiveness to ensure global consistency of world trade. Export market variables are determined in nominal terms as a weighted average of import demands of other regions, where the weights are also based on the trade share matrix of the base year:

$$
X M K T_{i, t}=\sum_{j} \frac{x_{i, j}}{m t o t_{j}} \cdot M_{j, t}
$$




\section{ECO/WKP(98)6}

where $M_{j, t}$ are nominal imports of region $j$. Exports are then modelled as a function of these market variables, assuming a price elasticity which is identical in all regions:

$$
\frac{X_{i, t}}{X_{i, b a s e}}=\frac{X M K T_{i, t}}{X M K T_{i, b a s e}}-\chi_{i} \frac{R X R_{i, t}}{R X R_{i, b a s e}}
$$

where $X_{i, t}$ stands for region $i$ nominal exports. The combination of elasticity constraints and the consistent measure of the relative export prices ensures that imports and exports are balanced in nominal terms at the world level ${ }^{81}$.

124. To ensure global consistency in net foreign assets, net investment income is modelled by applying a common interest rate to the stock of net assets held by each region:

$$
N F A_{i, t}=\left(1+i_{t}\right) N F A_{i, t-1}+X_{i, t}-M_{i, t}
$$

\subsection{Equilibrium conditions}

125. Two key variables in the model adjust to clear product and financial markets: the real interest rate and the real exchange rate. Real exchange rates adjust to ensure that within each region, aggregate demand is equal to aggregate supply in the market for goods. Real interest rates adjust to ensure that asset stocks and flows are in equilibrium at the world level. The mechanism by which equilibrium is achieved can be described as follows. In steady state equilibrium the target ratio of government debt to output is achieved and, for a given real interest rate, profit maximisation determines the ratio of the stock of physical capital to output. Households then achieve their desired asset holdings (physical capital plus bonds) by adjusting their net foreign asset positions, under the assumption of perfect asset substitutability. World real interest rates are then determined so as to ensure that net foreign assets across all regions sum to zero.

126. Given the assumption of perfect capital mobility ${ }^{82}$, real rates of returns on assets denominated in different currencies are equalised across regions according to the uncovered interest parity condition:

$$
\frac{P_{i, t}}{P_{j, t}}=\frac{P_{i, t+1}}{P_{j, t+1}} \cdot\left(1+i_{j, t}-i_{i, t}\right)
$$

127. In steady-state equilibrium, the exchange rate is constant and real interest rates (net of risk premia) are equalised across countries. To approximate the effect of differential real interest rates while avoiding the complication of modelling portfolio decisions, a sovereign risk premium is introduced for the two regions that comprise mainly non-OECD countries.

128. Expectations of future variables are assumed to be forward-looking and model consistent. The model is first solved for the long-run steady-state equilibrium to provide terminal conditions for the

81. Since there are no monetary aggregates in the model, the production price in one region is used as the numeraire and set to unity.

82. The implication of the assumption of perfect substitutability is that asset holdings are modelled on a net basis only. 
forward-looking expectations of variables used in simulation of the dynamic model namely: real exchange rates, real interest rates, human wealth and the marginal propensity to consume out of wealth.

\subsection{Model calibration and sensitivity analysis}

129. As a starting point for the analysis, the model is solved for an initial steady-state equilibrium in which all key ratios (most stock and variables being expressed as a proportion of output) and growth rates are assumed to be stable. This numerical steady state is obtained by choosing values for the fundamental parameters of the model and all the stock and flow variables, to reflect as far as possible the projected economic situations of the regions incorporated in the model in the year 2000. This is achieved by selecting ratios on the basis of values observed in recent data and then using the model's equations to determine the remaining variables residually to ensure internal consistency.

\subsubsection{Calibration of key variables}

130. The values chosen for the key ratios for each individual region are reported in Table $\mathrm{A} 2^{83}$. Since steady-state equilibrium is characterised as a point where the different economies would eventually converge in the absence of shocks, it does not represent the observed real world economic situation at any particular point in time. Therefore, for some variables there is bound to be a gap between the starting value chosen and that observed in true data.

131. To minimise such discrepancies, the model is calibrated on the basis of the medium-term scenario prepared for Economic Outlook No. 62. This projection is based on a number of assumptions including that by year 2000, many of the flow disequilibria currently observed will have been substantially reduced. However, given the assumptions regarding the steady-state of certain stock variables, the values of many flow variables are automatically determined by equilibrium conditions and, hence, some differ significantly from currently-observed values. For example, since the United States has net foreign liabilities, it is necessary to assume that it is running a trade surplus in the baseline "steady state" to cover interest payments, so that net liabilities remain a stable share of GDP.

\subsubsection{Choice of key parameters}

132. The choice of consumption parameters is in large part conditioned by empirical evidence which to date suggests a significant departure from Ricardian equivalence. Also, recent evidence pointing to a large effect of government debt on real interest rates appears to corroborate the view of a relatively weak response of consumption to changes in the real interest rate [see Seater (1993) and Campbell and Mankiw (1990)]. Consumption parameters having a key influence on the model properties include the intertemporal elasticity of substitution, the proportion of agents that are liquidity-constrained and the set of parameters defining the profile of labour income.

133. The selected values for key parameters are reported in the lower panel of Table A2. The elasticity of substitution is set at 0.33 , a value at the centre of a range of empirical estimates reported over

83. As a general rule, variables for the slow-ageing region are set as a residual from world data and the sum of the four fast-ageing regions. 


\section{ECO/WKP(98)6}

the past ten years ${ }^{84}$. The parameters for the labour income function are the same as used in Faruquee et al. (1996) ${ }^{85}$. Although there is little guidance regarding the specific parameter values in this case, there is ample evidence that labour income eventually drops as workers reach retirement age. Finally, the proportion of consumers constrained to consume after-tax labour income is set to 20 per cent. While Campbell and Mankiw (1990) suggest a proportion closer to 50 per cent, direct empirical evidence on the measure of the excess sensitivity of consumption to current income suggests a significantly lower proportion $^{86}$.

\subsubsection{Sensitivity to parameter choice}

134. To evaluate the relative influence of chosen parameters for model properties, a sensitivity analysis is conducted for the long-term responses to a permanent reduction of 10 percentage points in the ratio of government debt-to-GDP in all regions. The overall results for a selection of variables measured at the world level are reported in Table $\mathrm{A}^{87}$. In addition, a measure of the departure from Ricardian equivalence is shown for each set of parameters ${ }^{88}$.

135. The different combinations of parameter values are reported in an ascending order with respect to the size of the effect of government debt on the private sector of the model. The results from the first two columns illustrate that while a non-zero birth rate is necessary to introduce a significant departure from Ricardian equivalence in the standard Blanchard model, it is not sufficient to introduce significant effects of government policy on consumption, output or real interest rates.

136. The results reported in columns [4] to [7] show that the parameters having the most significant influence on the response of real interest rates to a change in government debt are those of the labour income profile and the elasticity of intertemporal substitution. The introduction of a hump-shaped profile for labour income triples the magnitude of the effect on the real interest rate relative to the standard Blanchard case, where labour income grows at a constant rate through time regardless of age. A reduction in the elasticity of consumption to the real interest rate from 0.5 to 0.33 doubles the interest rate effect. As a result, under the combination of parameters chosen for Minilink (column [7]), the effect of a change in government debt on the real interest rate is nearly ten times larger than that obtained under the basic Blanchard parameterisation ( 35 basis points compared with 4 basis points. Although this is about four times smaller than the low range of estimates found in Ford and Laxton (1995) and Helbling and

84. See Blundell (1989) for a survey of the empirical literature and Faruquee, Laxton and Symansky (1996) for a discussion of the most recent estimates.

85. While the introduction of a hump-shaped profile (as opposed to a constant-growth profile) for labour income is found to have an important influence on the properties of the model, these are not sensitive to small variations in the shape of the hump.

86. See Hayashi (1987) for a survey on liquidity constraints, as well as Flavin (1993) and Japelli and Pagano (1989) for further evidence.

87. In addition to the key parameters mentioned above the sensitivity analysis is extended to the birth rate and the probability of death (thereby implicitly the growth rate of population).

88. The degree of departure from pure Ricardian equivalence is measured here as the proportion of government bonds perceived as net wealth by consumers or, equivalently, the proportion of the reduction in government debt that is offset in the short run by a decline in private savings. 
Westcott (1995), it represents the centre of the range of estimates between empirical studies focusing on single-country variables and those based on world measures of government debt and real interest rate ${ }^{89}$.

\subsubsection{Responses to standard shocks}

137. To illustrate the main properties of the model, two simulations are performed analysing the effects of a government debt reduction and of an increase in the level of labour productivity in the three main OECD regions.

138. In the first case, summarised in Table A4, government debt is reduced progressively by up to 10 percentage points of GDP in the three main OECD regions (the United States, Japan and the European Union). This reduction is achieved primarily through a reduction of government expenditures equivalent to 1 percentage point of GDP, with taxes adjusting to maintain the longer-term target. Overall, these results suggest that the gradual decline in the demand for funds puts downward pressure on world real interest rates, which fall by between 20 to 30 basis points in the medium to long run. The decline in real interest rates raises the desired capital stock, which leads to higher levels of output, by $3 / 4$ to 1 per cent. Given the reduction in government expenditures in the three main OECD regions, aggregate supply exceeds domestic demand, putting downward pressure on the exchange rate against the mainly non-OECD regions. This, in turn, leads to trade surpluses and an accumulation of net foreign assets in the three main OECD regions. Conversely, in absence of any increase in public savings, higher interest rates and higher demand in the mainly non-OECD regions resulting from the decline in real interest rates induces a worsening of current accounts and a de-cumulation of net foreign assets.

139. In the second simulation, reported in Table A5, the level of labour efficiency is raised progressively by up to 10 per cent in the three main OECD regions, implying a similar rise in aggregate supply. Higher demand in these regions for imports leads to trade deficits and a de-cumulation of net foreign assets vis-à-vis the mainly non-OECD regions. This, in turn, puts downward pressures on exchange rates in the three main OECD regions. The temporary rise in the growth rate of labour efficiency and marginal productivity of capital induces higher real interest rates in the mainly OECD regions. In the long run, however, as labour efficiency and output stabilise at their new higher levels, real interest rates progressively return to their initial levels in all regions. A permanent depreciation of the main OECD currencies improves international competitiveness and trade balances in these regions so that the initial reduction in net foreign assets is completely offset. Overall, a permanent 10 per cent increase in output in the main OECD region leads to permanent real depreciation of the main OECD currencies by about 2 per cent. This estimate, however, depends on the size of import price elasticities used in the model. For example, reducing import price elasticities by 50 per cent (from 1.4 to 0.7 ), a real depreciation of about 5 (as opposed to 2) per cent is necessary to generate increases in trade balances sufficient to avoid changes in long-run net foreign asset positions.

\subsection{Comparisons with other model-based studies of ageing}

140. Table A6 provides a comparison of the main features of the approach used in the present study with a range of other recent studies of ageing. These are grouped into fine broad categories depending on the type of modelling approach used. 
141. The present study and that of Masson and Tryon (1990) are similar in using full dynamic general-equilibrium multi-region macro models. The main advantage of this approach is that of being able to analyse the effects of different ageing profiles across regions with key relative prices, such as real interest rates and exchange rates, and key stock and flow variables being determined endogenously and in a consistent fashion. The main limitation in both cases is the need for relatively ad hoc adjustments to the consumption function to capture demographic effects on private savings.

142. Studies in groups II and III are mostly based on partial equilibrium or closed-economy models, with consumption typically modelled on a representative consumer basis. These models tend to incorporate richer information for government or financial sectors but exclude a number of important domestic and international equilibrating factors.

143. Studies in groups IV and V incorporate overlapping generations (OLG) models of consumption and, thereby, embed strong links between individual savings behaviour, demographics and aggregate private savings. Studies in group IV include both general-equilibrium closed-economy versions and partial equilibrium (fixed price) open-economy versions. Studies in group V are mostly limited to private savings behaviour, their main strength being in the use of rich and detailed cohort specific data from household surveys. The general disadvantage of the OLG approach is that it is largely intractable in a multi-region context.

\section{Demographic assumptions underlying the reference scenario}

\subsection{Composition of the five regions}

144. The classification of countries other than the United States, Japan and the European Union into fast- or slow-ageing regions is based on the projected change in the dependency ratio derived from the United Nations projections to 2050. Countries where the dependency ratio increases over time are broadly classified as fast ageing, while those where it decreases are classified as slow ageing. The only exceptions to this rule among the larger countries (i.e. more than 100 million people) and the OECD countries are for Brazil and Turkey. The dependency ratios for these countries are about 4 percentage points higher in 2050 than in 1995, but are not generally associated with fast ageing, since it is only around 2045 that these dependency ratios regain their 1995 levels.

145. The "fast-ageing" regional group comprises OECD Member countries other than the United States, the European Union, Japan, Mexico and Turkey, plus all Eastern European countries (including Russia), China, China Hong-Kong, Korea, Singapore and Thailand. Chinese Taipei, which is not included in the UN projections is also included in this group ${ }^{90}$. The "slow-ageing" region is constructed as a residual by subtracting the population of the four other groups from the world population. This group includes all of Africa, Latin America and Asian countries other than China, China Hong-Kong, Chinese Taipei, Korea, Singapore and Thailand. The shares of the five regions in total population at the start and end of the projection period are reported in Table A7.

90. Population projections for Chinese Taipei are based on national sources and consistent with the behaviour of "fast ageing" countries. 


\subsection{Fertility and life-expectancy assumptions}

146. While the decline in fertility is the dominant factor in shaping the current and future demographic structure in the three main OECD regions, past and future increases in longevity also play an important role, particularly for Japan. These two sources of ageing have different implications for the trend population growth rate and living standards. A decline in fertility implies a slowdown in total population and labour force growth (assuming unchanged participation rates) and eventually a rise in the dependency ratio, albeit with a long lag. Persistent differences in fertility rates may also be an important source of differences in growth performance and lead to changes in the relative size of economies over time. However, if dependency ratios remain broadly unchanged, there is no clear effect on relative living standards. An increase in longevity raises temporarily the growth rate of total population, but not that of the labour force (assuming unchanged retirement age) and hence this implies a rise in the dependency ratio and a permanent reduction in living standards. The UN demographic projections are based on assumptions regarding fertility and longevity as reported in Figure A1.

\subsection{Extending population projections and dependency ratios beyond 2050}

147. The United Nations population projections end in 2050. Beyond this period, it is assumed that population growth rates in all regions converge to an average rate of 0.4 per cent per annum by 2080 , stabilising at this level thereafter. This is similar to the assumptions made in recent World Bank demographic projections (Bos et al., 1994), although convergence occurs at a somewhat later date (in 2150) and to a zero growth rate. Although a detailed demographic model would be necessary to achieve a fully consistent projection of dependency ratios beyond 2050, the information contained in the $\mathrm{UN}$ data set to 2050 is sufficient to derive a set of estimates consistent with a gradual converge towards a common level between 2050 and 2100 as described below.

\subsubsection{Extension of the UN projection of population by cohorts until 2200}

148. Given the basic UN data set, which includes population levels by age groups of five years up to 2050, it is possible to calculate an implicit death rate by cohort at the end of the period (by dividing the population of each cohort in 2050 by the population of the preceding cohort in 2045) ${ }^{91}$. Assuming that death rates per cohort remain constant beyond 2050 - which amounts to assuming that life expectancy stabilises and remains constant - the series for population by age groups can be extended using a method comparable to the perpetual inventory method.

149. In every period, the cohort of the zero to four years increases by the number of new-borns, less the number of individuals in that cohort who have either died or moved to the older cohort ${ }^{92}$ :

$$
P O P_{[0,4], t}=P O P_{[0,4], t-1} *\left(1+\rho_{[0,4]}\right) * 0.8+\operatorname{POPTOT~}-1_{t} *\left(1+\rho_{[T O T, t-1]}\right) *\left(1+n_{t}\right)
$$

\footnotetext{
91. The death rates of the two last cohorts cannot be calculated, but they are fixed at a level consistent with the profile of death rates by cohort (the same in the three main OECD regions).

92. This assumes that immigration does not play a role, which is consistent with the UN projections beyond 2025
} 


\section{ECO/WKP(98)6}

where POP ${ }_{[x, y]}$ denotes the population of the cohort $x-y$, POPTOT the total population, $\rho$ the death rate and $\mathrm{n}$ the growth rate of total population.

150. Similarly, the population of the older cohorts increases by the number of individuals who have graduated from the younger cohorts, less those who died or have moved to the older cohort: ${ }^{93}$

$$
P O P_{[x, y], t}=P O P_{[x, y], t-1} *\left(1+\rho_{[x, y]}\right) * 0.8+0.2 *\left(1-\rho_{[x-5, y-5]}\right) * P O P_{[x-5, y-5]}
$$

151. Initial estimates were made on this basis for the three main OECD regions, the fast-ageing regions and the world, with estimates for the slow-ageing countries obtained as the residual, to ensure consistency.

\subsubsection{Convergence in dependency ratios}

152. Initial estimates for the dependency ratios obtained using this method are shown in Figure A2. In the three main OECD regions, these estimates stabilise at about the same level by 2095 and converge thereafter to around 67 per cent. For the other two regions, since the probability of death by cohorts is somewhat higher than in the main OECD regions (especially for the older cohorts), the dependency ratios converge towards slightly lower levels ${ }^{94}$.

153. Given these initial estimates, dependency ratios were assumed for all regions to converge to a common level of 67 per cent by 2100 . For the three main OECD regions, the raw estimates were used up to 2079, and converge thereafter to 67 per cent by 2100 (Figure A3). For the other fast-ageing and slow-ageing regions, the basic dependency ratio estimates are used until they peak in 2062 and 2078, respectively converging thereafter to 67 per cent by 2100 (Figure A3).

\subsubsection{Share of the elderly in total population}

154. Similarly, the extended cohort projections were used to calculate the implicit shares of the elderly in total population, needed to assess the effects of ageing on public health expenditures. By about 2100 , the shares of elderly in total population converge to 18 per cent in the United States, Japan and the European Union. and to 15 per cent in the other two regions ${ }^{95}$. Given these initial estimates, the elderly ratios were fixed at a common level of 18 per cent by 2100 in all five regions, and kept constant thereafter (Figure A4).

93. The last cohort (80+) needs a special treatment since it loses only those who die. Hence, the first term of the equation is not multiplied by 0.8 .

94. This results from the fact that, to be consistent with the estimates of death rates obtained for other cohorts, the death rates of the older cohorts have been set at a higher level in these regions than in the main OECD regions. As they remain fixed afterwards, this implies that the dependency ratios of the former converge to a lower level than the latter in the long run. However, in the very long run, these death rates could be expected to converge towards the level observed in the other regions; implying, also, a convergence of dependency ratios.

95. The reasons for the discrepancy observed between the three more developed regions and the two others is the same as indicated in the previous footnote. 


\section{$2.4 \quad$ The probability of death}

155. Estimates of implicit aggregate death rates were also calculated based using the extended UN projections, by weighting the death rates by cohorts by the share of the cohort in total population. Given the changes in population structure in the four fast-ageing regions, the estimated aggregate death rates increase over the next fifty years despite a gradual decline in the death rates per cohort (reflecting the increase in life expectancy).

156. Estimated aggregate death rates are found to be closely correlated to the old age dependency ratio and the following rule linking increases in the probability of death to increase in the old-age dependency ratio was used to calculate the probability of death in the model:

$$
\rho_{t}=0.03+0.03 *\left(O L D D E P_{t}-O L D D E P_{2200}\right)
$$

where OLDDEP is the old age dependency ratio ${ }^{96}$. Figure A5 compares death rates based on such a rule with the aggregate death rates derived from the UN data base ${ }^{97}$.

\section{The financial implications of ageing for pensions}

157. The assessment of the effects on governments budgets arising from the effects of demographic pressures on pension systems in the reference scenario follows the broad approach of Roseveare et al. (1996), in which contributions made to and the benefits paid by the public pension schemes were projected for twenty OECD countries to 2070. Projections for the United States, Japan and four major European countries (France, Italy, Germany and United Kingdom) have been recalculated to incorporate more up-to-date demographic projections and to ensure that the assumptions on labour efficiency growth, GDP, wages and employment are consistent with the reference scenario. They have also been extended to $2200^{98}$.

158. The baseline scenarios of Roseveare et al. (1996) assume that government expenditure and revenue policies of that point in time continue indefinitely into the future. However, as far as possible, more recent legislated reforms such as increases in retirement age and/or decreases in the replacement rates are incorporated in the reference scenario estimates ${ }^{99}$. The resulting estimated balance between

96. The correlation is weaker in the case of the slow ageing countries, where the young cohorts still strongly influence the aggregate death rate.

97. The series shown in Figure A5 for the aggregate mortality derived from the UN data base have been rescaled so that their starting point level is the same as that of the probability of death used in the model. Given that the death rate derived implicitly from the UN database can only be a rough approximation to the true aggregate death rate, it was considered preferable to set the probability of death parameter using a simple rule rather than try to match its profile exactly.

98. In all countries, the ratio of contributions to GDP is stabilised at the end of the projection period, and is assumed to remain constant until 2200. To extend the series of benefits to GDP, the coefficient of correlation between its growth rate and the growth rate of the old age dependency ratio between 1995 and 2080 is calculated and then used to extend the series from 2080 to 2200 .

99. In the case of Italy, it was not possible to take account of the most recent reform plans (the Prodi Agreement) adopted in December 1997. Instead, the assumptions are based on estimates of the likely effects of the 1995 Dini reforms (in particular with respect to the retirement age), broadly consistent with the estimates reported in OECD Economic Surveys, Italy, 1997). 


\section{ECO/WKP(98)6}

contributions and benefits (as a percentage of GDP), representing the effects of ageing on public pension transfers for the three main OECD regions are reported in Figure 13 of the main text. These estimates suggest that public pension schemes would be in deficit for all countries except the United Kingdom, where the public system now provides only a minor share of pension benefits.

159. The alternative "later retirement" scenario, presented in section 3 of the main text, was constructed for all countries excluding the United Kingdom. The explicit assumptions concerning the increase in retirement ages and their timing for both scenarios are described in Table 9 of the main text. Delaying the retirement age affects the financial balance of public pension schemes through two channels: first, it reduces the benefits paid, by reducing the number of retirees; second, it increases contributions, by increasing the labour force and thus the payroll.

160. In both scenarios, the aggregate balance for Europe is obtained by weighting the balance of each of the four largest countries according to 1992 GDP shares (measured in purchasing power parities), Figure A.6 also reports the reductions in net public pension expenditures arising from the implementation of the later retirement scenario for France, Germany and Italy ${ }^{100}$. The increase in the participation rate implied by the later retirement scenario in the three regions is reported in Figure 14 of the main text.

\section{4. "Rules-of-thumb" for government debt}

161. In the reference scenario the target for the ratio of public debt to GDP is allowed to drift upwards as a result of increases in primary government expenditures according to a fixed rule. This rule is intended to broadly characterise the experience of fiscal slippage in the main OECD countries since the early 1970s. Thus, following upwards pressures on public expenditure, governments typically failed to find offsetting cuts which given delays in raising taxes, led to a build-up in public debt.

162. To quantify this rule, net public debt as a share of GDP (D) was regressed on its lagged value, and both current and lagged values of primary expenditures as a share of GDP (PRIMEXP), using data for the OECD as a whole between 1969 and 1996:

$$
D_{t}=\alpha+\beta^{*} D_{t-1}+\gamma_{1} * \operatorname{PRIMEXP}_{t}+\gamma_{2} * \operatorname{PRIMEXP}_{t-1}+\ldots+\gamma_{n} * \operatorname{PRIMEXP}_{t-n}
$$

163. The corresponding results are summarised in Table A7. As more lagged terms in the primary expenditure ratio are introduced, the first lagged terms become insignificant. The last row of the Table gives the long run response of the debt ratio to an increase in the primary expenditure ratio by 1 per cent of GDP. Based on these results, the increase in long-run target for government debt in the reference scenario was specified as being six times any increase in primary expenditures (being a rough average of the two estimated long-run responses). It is emphasised that this provides a rule for the long-run debt target and not the dynamic evolution of the debt ratio.

\section{Analysing changes in living standards}

164. The measure of living standards used in comparisons in sections 2 and 3 of the main text can be decomposed into a number of separate elements. The derivation outlined below combines the expression

100. It was verified that the results obtained for the European aggregate are only slightly different when the weights are allowed to move over time. 
for employment in terms of demographic variables with an expression for per capita output derived from a Cobb-Douglas production function.

i) Expressing employment in terms of demographic variables

By definition:

$$
\begin{aligned}
\mathrm{D} & =(\mathrm{POP}-\mathrm{PWA}) / \mathrm{PWA} \\
\mathrm{N} & =\left(1-\mathrm{UR}^{*}\right) . \mathrm{LF} \\
\mathrm{LF} & =\theta . \mathrm{PWA}
\end{aligned}
$$

where:

$$
\begin{array}{lll}
\mathrm{D} & = & \text { Dependency rate } \\
\mathrm{POP} & = & \text { Total population, } \\
\mathrm{PWA} & = & \text { Population of working age }, \\
\mathrm{N} & =\text { Employment } \\
\mathrm{UR}^{*} & =\text { NAIRU }, \\
\mathrm{LF} & =\text { Labour Force, } \\
\theta & =\text { Participation rate }
\end{array}
$$

Combining these definitions and eliminating PWA gives:

$$
\mathrm{N}=\left(1-\mathrm{UR}^{*}\right) \cdot \theta \cdot \mathrm{POP} /(1+\mathrm{D}) .
$$

Taking logs (where lower case denote logs) gives:

$$
\mathrm{n}=\ln \left(1-\mathrm{UR}^{*}\right)+\ln \theta+\text { pop }-\ln (1+\mathrm{D}) .
$$

ii) Decomposing per capita output, assuming a Cobb-Douglas technology

Output from a Cobb-Douglas production function can be expressed in logarithmic form as:

$$
y=\alpha(n+e)+(1-\alpha) k
$$

where: $\quad \mathrm{y}=$ output,

$\mathrm{k}=$ capital stock,

$\mathrm{e}=$ Labour efficiency,

$\alpha=$ wage share parameter.

Rearranging gives:

$$
y=(n+e)+[(1-\alpha) / \alpha] .(k-y) .
$$




\section{ECO/WKP(98)6}

Eliminating $\mathrm{n}$ from equation [30] using equation [31], and rearranging gives an expression for GDP per capita (logged) as follows:

$$
(\mathrm{y}-\mathrm{pop})=\mathrm{e}-\ln (1+\mathrm{D})+[(1-\alpha) / \alpha] .(\mathrm{k}-\mathrm{y})+\ln \left(1-\mathrm{UR}^{*}\right)+\ln \theta .
$$

iii) Adjusting output per capita for the terms of trade

165. Two further adjustments are made to derive the final expression for living standards. Firstly, GDP is replaced by GNP $\left(\mathrm{Y}^{*}\right)$, where $\mathrm{y}^{*}=\beta+\mathrm{y}$, and $\beta$ represents the contribution of investment income. Secondly, a terms-of-trade adjustment is made to reflect the consumption possibilities of any level of GNP, given that income is used to purchase domestic absorption (with price $\mathrm{P}^{*}$ ) rather than domestic production (with price P). Making these adjustments, the final expression for living standards, GNP per capita adjusted for terms-of-trade effects, is given by:

$$
\left(y^{*}-p o p\right)+\left(p-p^{*}\right)=e-\ln (1+D)+[(1-\alpha) / \alpha] .(k-y)+\ln \left(1-U^{*}\right)+\ln \theta+\beta+\left(p-p^{*}\right),
$$

where the terms on the right-hand side of equation [33] are, respectively, the contributions from ${ }^{101}$ :

- growth in labour efficiency (positive);

- changes in dependency ratios (negative);

- changes in capital intensity of production (positive);

- changes in the NAIRUs (negative);

- changes in participation rates (positive);

- changes in investment income (positive);

- changes in the terms of trade (positive).

\section{Policy simulation results in detail}

166. Tables A9 to A17 provide further details of changes (relative to baseline) for key variables and regions in each of the simulations as specified in section 3 of the main paper as follows:

A9 - $\quad$ OECD-wide debt stabilisation

A10 - Debt stabilisation in Japan only

A11 - Debt stabilisation, with an increase in the retirement age

A12 - Increase in the retirement age, with debt reduction in the United States and Europe

A13 - Debt stabilisation, with an increase in the retirement age implemented with a ten-year lag

A14 - Higher labour force participation rates and lower European unemployment

A15 - $\quad$ Higher levels of total factor productivity

101. The terms in brackets refer to the partial derivatives with respect to increases in each of these factors. 
ECO/WKP(98)6

A16 - Faster growth in the two mainly non-OECD regions

A17 - Combined reforms 
ECO/WKP(98)6

Table A1. Key relationships in the Minilink model

\begin{tabular}{|c|c|}
\hline STEADY-STATE MODEL & DYNAMIC ADJUSTMENT MODEL \\
\hline \multicolumn{2}{|c|}{ Production Sector } \\
\hline$Y_{t}=K_{t}^{1-\alpha} \cdot(L \cdot E L E F)_{t}^{\alpha}$ & Same as steady-state \\
\hline Capital-output ratio $\quad k_{t}=\frac{\left(1+g_{t}\right)}{\left(g_{t}+\delta\right)} \cdot\left(1-c_{t}-g c_{t}-x v_{t}+m v_{t}\right)$ & $k_{t}=\frac{(1-\delta)}{\left(1+g_{t}\right)} k_{t-1}+\left(1-c_{t}-g c_{t}-x v_{t}+m v_{t}\right)$ \\
\hline$R_{t}=(1-\alpha)\left(1+g_{t}\right) / k_{t}-\delta-r i s k$ & Same as steady-state \\
\hline$g_{t}=\left(1+n_{t}\right) \cdot\left(1+z_{t}\right)-1$ & $g_{t}=\left(Y_{t} / Y_{t-1}\right)-1$ \\
\hline \multicolumn{2}{|c|}{ Government sector } \\
\hline Government debt & $b_{t}=\frac{\left(1+R_{t}\right)}{\left(1+g_{t}\right)} \cdot b_{t-1}+g c_{t}+\operatorname{trf} f_{t}-\operatorname{tax}_{t}$ \\
\hline $\operatorname{tax}_{t}=g c_{t}+\operatorname{trf} f_{t}+\left(R_{t}-g_{t}\right) * b_{t}$ & $\operatorname{tax}_{t}=\operatorname{tax}_{t-1}+a_{1} \cdot\left(b_{t}-\overline{b_{t}}\right)+a_{2} \cdot\left(b_{t}-b_{t-1}\right)$ \\
\hline Education $\quad e d u c_{t} / e d u c_{\text {base }}=\left(Y_{\text {OUNG }} / \mathrm{YOUNG}_{\text {base }}\right) *\left(L_{\text {base }} / L_{t}\right)$ & Same as steady-state \\
\hline Health $\quad H P C A P A D J_{t} / H P C A P A D J_{\text {base }}=P D T Y_{t} / P D T Y_{\text {base }}$ & Same as steady-state \\
\hline
\end{tabular}


Table A1 (contd.)

\begin{tabular}{|l|c|c|}
\hline \multicolumn{2}{|c|}{ STEADY-STATE MODEL } & DYNAMIC ADJUSTMENT MODEL \\
\hline \multicolumn{2}{|c|}{ Household sector } \\
\hline Consumption $\quad c_{t}=\left(\Omega_{t} t w+\left(\beta \lambda_{1}+(1-\beta) \lambda_{2}\right)[1-\tau]\right) \cdot P_{t} / P C_{t}$ & $c_{t}=\omega \cdot c_{t-1}+\left[(1-\omega) \cdot\left(\Omega_{t} t w+\left(\beta \lambda_{1}+(1-\beta) \lambda_{2}\right)[1-\tau]\right) \cdot P_{t} / P C_{t}\right]$ \\
\hline Total $\left.t w_{t}=f w_{t}+\beta\left(1-\lambda_{1}\right) h w_{1, t}+(1-\beta)\left(1-\lambda_{2}\right) h w_{2, t}\right)$ wealth & Same as steady-state \\
\hline Propensity $\Omega_{t}=(\gamma-1 / \gamma) \cdot R_{t}+\rho+(\phi / \gamma)$ to consume & $\Omega_{t}^{-1}=\Omega_{t+1}^{-1} /\left(1+\left((\gamma-1 / \gamma) \cdot R_{t}+\rho+(\phi / \gamma)\right.\right.$ \\
\hline Human wealth $\quad h w_{t}=\frac{\left(\alpha-t a x_{t}+t r f_{t}+r i s k \cdot k_{t}\right)}{R_{t}+\rho-z_{t}+\alpha_{i}}$ & $h w_{t}=\frac{\left(\alpha_{t}-t a x_{t}+t r f_{t}+r i s k_{t} * k_{t-1}\right)}{\left(1+g_{t}\right)}$ \\
\hline Financial wealth $\quad f w_{t}=k_{t}+b_{t}+n f a_{t}$ & Same as steady-state \\
\hline Consumer price $\quad P C_{t}=\left(1-w_{t+1}^{f}\right) P_{t}+w^{f} P M_{t}$ & Same as steady-state \\
\hline Probability of death $\quad \rho_{t}=\Lambda_{0}+\Lambda_{1} \cdot\left(O L D D E P_{t}-O L D D E P_{b a s e}\right)$ & Same as steady-state \\
\hline
\end{tabular}


Table A1 (contd.)

\begin{tabular}{|c|c|}
\hline STEADY-STATE MODEL & DYNAMIC ADJUSTMENT MODEL \\
\hline \multicolumn{2}{|c|}{ External Sector } \\
\hline$\frac{M V_{i, t}}{M V_{i, \text { base }}}=\frac{c_{i, t}}{c_{i, \text { base }}}+\theta_{i} L O G \frac{\left(P_{i, t} / P M_{i, t}\right)}{\left(P_{i, \text { base }} / P M_{i, \text { base }}\right)}$ & Same as steady-state \\
\hline$P M_{i, t} / P M_{i, \text { base }}=\sum_{j} \frac{x_{j, i}}{m t o t} \cdot \frac{P_{j, t}}{P_{j, b a s e}}$ & Same as steady-state \\
\hline 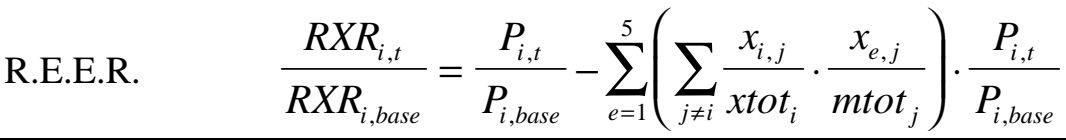 & Same as steady-state \\
\hline$X M K T_{i, t}=\sum_{j} \frac{x_{i, j}}{\text { mtot }_{j}} \cdot M_{j, t}$ & Same as steady-state \\
\hline 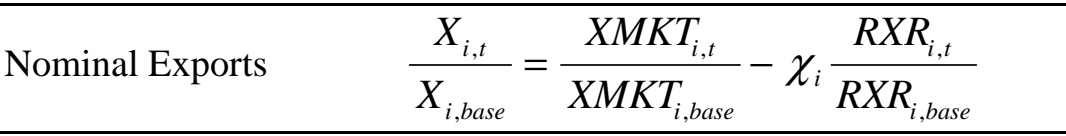 & Same as steady-state \\
\hline$n f a_{t}=\frac{\left(1+g_{t}\right)}{\left(g_{t}-R_{t}\right)} \cdot\left(x v_{t}-\left(m v_{t} \cdot\left(P M_{t} / P_{t}\right)\right)\right.$ & $n f a_{t}=\frac{\left(1+R_{t}\right)}{\left(1+g_{t}\right)} n f a_{t-1}+\left(x v_{t}-\left(m v_{t} \cdot \frac{P M_{t}}{P_{t}}\right)\right)$ \\
\hline & UIP condition $\quad \frac{P_{t}}{P_{t}^{f}}=\frac{P_{t+1}}{P_{t+1}^{f}} \cdot\left(1+R_{t}^{f}-R_{t}\right)$ \\
\hline \multicolumn{2}{|c|}{ Equilibrium conditions } \\
\hline \multicolumn{2}{|c|}{ Goods market equilibrium } \\
\hline $1=c_{t}+\frac{\left(\delta+g_{t}\right)}{\left(1+g_{t}\right)} \cdot k_{t}+g c_{t}+x v_{t}-m v_{t}$ & $1=c_{t}+\left(k_{t}-\frac{(1-\delta)}{\left(1+g_{t}\right)} \cdot k_{t-1}\right)+g c_{t}+x v_{t}-m v_{t}$ \\
\hline \multicolumn{2}{|c|}{ Financial market equilibrium } \\
\hline$\sum n f a_{i, t} \cdot P_{i, t} \cdot Y_{i, t}=0$ & Same as steady-state \\
\hline
\end{tabular}


Definitions of variables and parameters in Table A1

\section{Stock and flow variables}

$\operatorname{tax}$

$g c$

inv

$\operatorname{trf}$

educ

$\bar{b}$

$b$

$h w$

fw

tw

$c$

$\Omega$

$n f a$

$m v$

$x v$

$x_{i . i}$

mtot $_{i}$

$x_{\text {tot }}$

$M V$

$X V$

$X M K T$

$Y$

E

K

ELEF

$P D T Y$

YOUNG

OLDDEP

HPCAPADJ

$f$ superscript

base superscript

Price variables

$R$

rxr

$P$

$P C$

$P M$ capital-output ratio

tax rate on labour income

government expenditures as a proportion of output

gross investment as a proportion of output

government transfers as a proportion of output

education spending as a proportion of output

government debt as a proportion of output

government debt target as a proportion of output

human wealth $\mathrm{s}$ a proportion of output

financial wealth as a proportion of output

total wealth as a proportion of output

consumption as a proportion of output

propensity to consume out of total wealth

net foreign assets as a proportion of output

real imports as a proportion of output

real exports as a proportion of output

value of exports of country $j$ to country $i$

total imports of country $\mathrm{i}$

total exports of country $i$

level of imports (volume)

level of exports (volume)

level of nominal export markets

level of real output

employment

level of capital stock

labour augmenting technical efficiency

level of labour productivity

share of people aged 0-15 in total population

old-age dependency ratio

age-adjusted health spending per capita

refers to a foreign variable

refers to a base year

real interest rate

real exchange rate

price of domestic good

consumer price

import price

Time varying parameters

$g$

$n$

dep

$\rho$

Fixed parameters

$\delta$

risk

$\phi$

$\gamma$

$\alpha$

$\chi$

growth rate of output

growth rate of labour force

growth rate of labour efficiency

dependency ratio

probability of death

rate of capital depreciation

equity risk premium

rate of time preference

degree of risk aversion

share of labour in total income

import price elasticity

export price elasticity 
Table A2. Initial values of key variables and parameters

\begin{tabular}{|c|c|c|c|c|c|}
\hline \multirow[b]{2}{*}{ Variables in 2000} & United States & Japan & $\begin{array}{l}\text { European } \\
\text { Union }\end{array}$ & $\begin{array}{c}\text { Fast-ageing } \\
\text { other } \\
\text { countries }\end{array}$ & $\begin{array}{c}\text { Slow- } \\
\text { ageing } \\
\text { other } \\
\text { countries }\end{array}$ \\
\hline & & & & & \\
\hline \multicolumn{6}{|l|}{ Production sector } \\
\hline Share of world population (per cent) & 5 & 2 & 7 & 30 & 56 \\
\hline Share of world GDP (per cent) & 20 & 7 & 19 & 25 & 28 \\
\hline Share of capital in total income (per cent) & 30 & 32 & 32 & 38 & 38 \\
\hline Capital-output ratio & 2.1 & 2.2 & 2.2 & 2.1 & 2.1 \\
\hline Private investment (per cent of GDP) & 13 & 14 & 14 & 17 & 17 \\
\hline Real interest rate (per cent) & 5 & 5 & 5 & 7 & 7 \\
\hline of which: Sovereign risk premium & 0 & 0 & 0 & 2 & 2 \\
\hline $\begin{array}{l}\text { Growth of labour efficiency } \\
\text { (per cent per annum) }\end{array}$ & 1.4 & 1.4 & 1.4 & 1.4 & 1.4 \\
\hline Dependency ratio (per cent) & 50 & 48 & 49 & 44 & 66 \\
\hline NAIRU & 5.5 & 2.8 & 9.5 & -- & -- \\
\hline \multicolumn{6}{|l|}{ Government sector (per cent of GDP) } \\
\hline Government consumption & 15 & 9 & 18 & 12 & 14 \\
\hline Net transfers & 16 & 26 & 28 & 17 & 10 \\
\hline Total taxes & 31 & 35 & 47 & 29 & 25 \\
\hline Net debt & 43 & 23 & 57 & 10 & 19 \\
\hline \multicolumn{6}{|l|}{ Consumption sector (per cent of GDP) } \\
\hline Private consumption & 72 & 78 & 68 & 71 & 69 \\
\hline Human wealth & 471 & 507 & 437 & 371 & 359 \\
\hline Financial wealth & 237 & 272 & 291 & 230 & 227 \\
\hline Share of world financial wealth & 19 & 8 & 22 & 24 & 26 \\
\hline Total wealth & 708 & 779 & 728 & 601 & 586 \\
\hline \multicolumn{6}{|l|}{ External sector (per cent of GDP) } \\
\hline Exports & 14 & 14 & 13 & 16 & 10 \\
\hline Imports & 14 & 14 & 13 & 16 & 10 \\
\hline Trade balance & 0.43 & -0.65 & -0.25 & -0.15 & 0.17 \\
\hline Net foreign asset position & -16 & 25 & 10 & 5 & -6 \\
\hline \multicolumn{6}{|l|}{ Parameter assumptions } \\
\hline Capital depreciation rate & 0.035 & 0.035 & 0.035 & 0.05 & 0.05 \\
\hline Elasticity of intemporal substitution & 0.33 & 0.33 & 0.33 & 0.33 & 0.33 \\
\hline Rate of time preference & 0.049 & 0.045 & 0.033 & 0.054 & 0.052 \\
\hline Export price elasticity & 1.0 & 1.0 & 1.0 & 1.0 & 1.0 \\
\hline Import price elasticity & 1.4 & 1.4 & 1.4 & 1.4 & 1.4 \\
\hline
\end{tabular}

Source: OECD; United Nations (1996); World Bank, World Development Indicators (1997). 
Table A3. Effects of a reduction in government debt on selected variables of the model under alternative parameter values

ECO/WKP(98)6

\begin{tabular}{|c|c|c|c|c|c|c|c|c|c|}
\hline & $\begin{array}{c}\text { Pure } \\
\text { Ricardian }^{1}\end{array}$ & $\begin{array}{c}\text { Blanchard }^{1} \\
\text { (1) with } \\
\text { non-zero } \\
\text { birth rate } \\
\text { (2) }\end{array}$ & $\begin{array}{l}\text { (2) with } \\
\text { liquidity } \\
\text { constraint }\end{array}$ & $\begin{array}{c}\text { FLS }^{2} \\
\text { (2) with } \\
\text { hump- } \\
\text { shaped } \\
\text { income } \\
(4) \\
\end{array}$ & $\begin{array}{c}\text { FLS } \\
\text { (4) with } \\
\text { liquidity } \\
\text { constraint } \\
\text { (5) } \\
\end{array}$ & $\begin{array}{c}\text { (5) with } \\
\text { higher } \\
\text { birth and } \\
\text { death rates } \\
(6)\end{array}$ & $\begin{array}{l}\text { MINILINK } \\
\text { (6) with } \\
\text { elast. of sub. } \\
\text { of } 0.33 \\
\text { (7) }\end{array}$ & $\begin{array}{l}\text { (6) with } \\
\text { elast. of } \\
\text { sub. } 0.25\end{array}$ & $\begin{array}{c}\text { Ball and } \\
\text { Mankiw } \\
\text { Accounting } \\
\text { Framework } \\
(9) \\
\end{array}$ \\
\hline \multicolumn{10}{|l|}{ Key parameters: } \\
\hline Lifetime labour income profile & $\begin{array}{l}\text { constant } \\
\text { growth }\end{array}$ & $\begin{array}{l}\text { constant } \\
\text { growth }\end{array}$ & $\begin{array}{l}\text { constant } \\
\text { growth }\end{array}$ & $\begin{array}{l}\text { hump- } \\
\text { shaped }\end{array}$ & $\begin{array}{l}\text { hump- } \\
\text { shaped }\end{array}$ & $\begin{array}{l}\text { hump- } \\
\text { shaped }\end{array}$ & hump-shaped & $\begin{array}{l}\text { hump- } \\
\text { shaped }\end{array}$ & -- \\
\hline Proportion of liquidity -constrained agents & 0.0 & 0.0 & 0.20 & 0.0 & 0.20 & 0.20 & 0.20 & 0.20 & -- \\
\hline Elasticity of intertemporal substitution & 0.50 & 0.50 & 0.50 & 0.50 & 0.50 & .50 & 0.33 & 0.25 & -- \\
\hline Birth rate & 0.00 & 0.025 & 0.025 & 0.025 & 0.025 & 0.0304 & 0.0304 & 0.0304 & -- \\
\hline Probability of death (inverse of life horizon) & 0.025 & 0.025 & 0.025 & 0.025 & 0.025 & 0.03 & 0.03 & 0.03 & -- \\
\hline \multicolumn{10}{|l|}{ Effects on: ${ }^{3}$} \\
\hline Public debt (percentage points of GDP) & -10.0 & -10.0 & -10.0 & -10.0 & -10.0 & -10.0 & -10.0 & -10.0 & -10.0 \\
\hline Capital stock (percentage points of GDP) & 0.0 & 0.6 & 0.7 & 1.9 & 2.8 & 2.9 & 5.4 & 9.7 & 7.0 \\
\hline Financial wealth (percentage points of GDP) & -10.0 & -9.4 & -9.3 & -8.1 & -7.2 & -7.1 & -4.6 & -0.3 & -3.0 \\
\hline $\begin{array}{l}\text { Level of output (per cent deviation from } \\
\text { baseline }\end{array}$ & 0.0 & 0.1 & 0.2 & 0.4 & 0.6 & 0.7 & 1.3 & 2.2 & 1.3 \\
\hline $\begin{array}{l}\text { Level of consumption (per cent deviation } \\
\text { from baseline) }\end{array}$ & 0.0 & 0.1 & 0.1 & 0.3 & 0.4 & 0.4 & 0.8 & 1.4 & 1.3 \\
\hline Real interest rate (basis points) & -0 & -4.0 & -4.6 & -12.5 & -18.2 & -19.1 & -35.2 & -61.6 & -33 \\
\hline $\begin{array}{l}\text { Degree of departure from Ricardian } \\
\text { equivalence }^{4} \text { (per cent) }\end{array}$ & 0 & 42 & 53 & 58 & 75 & 76 & 76 & 76 & 100 \\
\hline
\end{tabular}

1. Blanchard's model except with elasticity of substitution of 0.5 instead of 1.0.

2. Faruquee et. al (1996) examine the effects of introducing the hump-shaped income profile and liquidity constraints jointly and separately using a variety of different values for the probability of death and birth rate.

3. All variables are measured as "world" variables, i.e. the sum across the five regions weighted by the shares in world GDP.

4. Measured as the proportion of government bonds perceived by private consumers as part of their wealth. 
Table A4. Debt reduction in the US, Japan and European Union by 10 per cent of GDP (Difference from the reference case)

\section{United States}

GDP level (per cent)

GNP level (per cent)

Human Wealth (\% of GDP)

Financial Wealth ( $\%$ of GDP) of which

Capital Stock (\% of GDP)

Net Government debt (\% of GDP)

Net foreign assets (\% of GDP)

Current balance (\% of GDP)

Trade Balance ( $\%$ of GDP)

Investment Income Balance (\% of GDP)

Consumption (\% of GDP)

Govt Consumption (\% of GDP)

Investment (\% of GDP)

Net exports ( $\%$ of GDP)

Real effective Exchange rate (per cent)

Real Interest rates (percentage point)

\section{Japan}

GDP level (per cent)

GNP level (per cent)

Human Wealth (\% of GDP)

Financial Wealth (\% of GDP)

of which

Capital Stock (\% of GDP)

Net Government debt (\% of GDP)

Net foreign assets (\% of GDP)

Current balance ( $\%$ of GDP)

Trade Balance ( $\%$ of GDP)

Investment Income Balance (\% of GDP)

Consumption (\% of GDP)

Govt Consumption (\% of GDP)

Investment $(\%$ of GDP)

Net exports (\% of GDP)

Real effective Exchange rate (per cent)

Real Interest rates (percentage point)

\section{European Union}

GDP level (per cent)

GNP level (per cent)

Human Wealth (\% of GDP)

Financial Wealth (\% of GDP)

of which

Capital Stock (\% of GDP)

Net Government debt (\% of GDP)

Net foreign assets (\% of GDP)

Current balance ( $\%$ of GDP)

Trade Balance ( $\%$ of GDP)

Investment Income Balance (\% of GDP)

Consumption (\% of GDP)

Govt Consumption (\% of GDP)

Investment (\% of GDP)

Net exports (\% of GDP)

Real effective Exchange rate (per cent)

Real Interest rates (percentage point)

$\begin{array}{rrrrrr}0.5 & 0.9 & 0.9 & 0.8 & 0.7 & 0.7 \\ 0.6 & 1.2 & 1.3 & 1.3 & 1.2 & 1.1 \\ & & & & & \\ 23.1 & 27.7 & 26.8 & 25.2 & 24.3 & 24.2 \\ -2.2 & -0.2 & 2.3 & 3.0 & 2.7 & 0.2 \\ & & & & & \\ 2.7 & 4.3 & 4.4 & 4.0 & 3.6 & 3.5 \\ -7.7 & -10.6 & -10.3 & -10.0 & -10.0 & -10.0 \\ 2.8 & 6.0 & 8.1 & 9.0 & 9.0 & 6.7 \\ & & & & & \\ 0.4 & 0.4 & 0.3 & 0.2 & 0.1 & 0.1 \\ 0.3 & 0.1 & -0.1 & -0.3 & -0.4 & -0.2 \\ 0.1 & 0.3 & 0.4 & 0.5 & 0.5 & 0.3 \\ & & & & & \\ 0.1 & 0.5 & 0.9 & 1.2 & 1.3 & 1.1 \\ -1.0 & -1.0 & -1.0 & -1.0 & -1.0 & -1.0 \\ 0.5 & 0.3 & 0.2 & 0.2 & 0.2 & 0.2 \\ 0.4 & 0.2 & -0.1 & -0.3 & -0.4 & -0.3 \\ & & & & & \\ -0.6 & -0.4 & -0.1 & 0.2 & 0.3 & 0.1 \\ -0.2 & -0.3 & -0.3 & -0.3 & -0.2 & -0.2\end{array}$

$\begin{array}{rrrrrr}0.6 & 1.0 & 1.1 & 1.0 & 0.9 & 1.0 \\ 0.7 & 1.4 & 1.6 & 1.7 & 1.6 & 1.3 \\ & & & & & \\ 26.0 & 31.7 & 31.2 & 29.3 & 27.8 & 28.7 \\ -2.3 & -0.4 & 2.3 & 3.5 & 3.7 & -2.0 \\ & & & & & \\ 3.0 & 4.9 & 5.0 & 4.5 & 4.1 & 4.6 \\ -7.6 & -10.5 & -10.2 & -10.0 & -10.0 & -10.0 \\ 2.4 & 5.2 & 7.5 & 9.0 & 9.6 & 3.4 \\ & & & & & \\ 0.3 & 0.4 & 0.3 & 0.3 & 0.2 & -0.1 \\ 0.2 & 0.0 & -0.3 & -0.5 & -0.6 & -0.5 \\ 0.1 & 0.4 & 0.6 & 0.7 & 0.8 & 0.3 \\ & & & & & \\ 0.1 & 0.6 & 1.1 & 1.4 & 1.6 & 1.4 \\ -1.0 & -1.0 & -1.0 & -1.0 & -1.0 & -1.0 \\ 0.6 & 0.4 & 0.2 & 0.2 & 0.2 & 0.3 \\ 0.3 & 0.0 & -0.3 & -0.6 & -0.7 & -0.7 \\ & & & & & \\ -0.6 & -0.2 & 0.3 & 0.8 & 1.1 & 1.1 \\ -0.2 & -0.3 & -0.3 & -0.3 & -0.3 & -0.3\end{array}$

$\begin{array}{rrrrrr}0.5 & 1.0 & 1.0 & 0.9 & 0.9 & 0.7 \\ 0.7 & 1.4 & 1.6 & 1.7 & 1.7 & 1.4 \\ & & & & & \\ 23.7 & 29.0 & 28.6 & 27.3 & 26.3 & 24.8 \\ -2.1 & 0.4 & 3.9 & 5.5 & 5.8 & 3.7 \\ & & & & & \\ 2.8 & 4.6 & 4.9 & 4.5 & 4.1 & 3.4 \\ -7.8 & -10.6 & -10.3 & -10.0 & -10.0 & -10.0 \\ 2.8 & 6.4 & 9.3 & 11.0 & 11.6 & 10.3 \\ & & & & & \\ 0.4 & 0.4 & 0.4 & 0.3 & 0.2 & 0.2 \\ 0.3 & 0.0 & -0.2 & -0.4 & -0.6 & -0.5 \\ 0.2 & 0.4 & 0.6 & 0.8 & 0.8 & 0.7 \\ & & & & & \\ 0.0 & 0.5 & 1.0 & 1.3 & 1.5 & 1.4 \\ -1.0 & -1.0 & -1.0 & -1.0 & -1.0 & -1.0 \\ 0.6 & 0.4 & 0.2 & 0.2 & 0.2 & 0.1 \\ 0.4 & 0.1 & -0.2 & -0.5 & -0.7 & -0.6 \\ & & & & & \\ -0.5 & -0.3 & 0.0 & 0.3 & 0.5 & 0.4 \\ -0.2 & -0.3 & -0.3 & -0.3 & -0.3 & -0.2\end{array}$


Table A5. Increase in the level of labour efficiency in the US, Japan and European Union by 10 per cent

(Difference from the reference case)

\section{United States}

GDP level (per cent)

GNP level (per cent)

Human Wealth (\% of GDP)

Financial Wealth (\% of GDP)

of which

Capital Stock (\% of GDP)

Net Government debt (\% of GDP)

Net foreign assets (\% of GDP)

Current balance (\% of GDP)

Trade Balance ( $\%$ of GDP)

Investment Income Balance (\% of GDP)

Consumption (\% of GDP

Govt Consumption (\% of GDP)

Investment (\% of GDP)

Net exports (\% of GDP)

Real effective Exchange rate (per cent)

Real Interest rates (percentage point)

\section{Japan}

GDP level (per cent

GNP level (per cent)

Human Wealth (\% of GDP)

Financial Wealth ( $\%$ of GDP)

of which

Capital Stock (\% of GDP)

Net Government debt (\% of GDP)

Net foreign assets (\% of GDP)

Current balance ( $\%$ of GDP)

Trade Balance (\% of GDP)

Investment Income Balance (\% of GDP)

Consumption (\% of GDP)

Govt Consumption (\% of GDP)

Investment (\% of GDP)

Net exports (\% of GDP)

Real effective Exchange rate (per cent)

Real Interest rates (percentage point)

$\begin{array}{rrrrrr}3.1 & 7.7 & 9.0 & 9.8 & 10.1 & 10.0 \\ 2.9 & 7.0 & 8.3 & 9.4 & 10.0 & 10.0 \\ & & & & & \\ -10.2 & -20.2 & -5.1 & 2.0 & 3.0 & -0.5 \\ -10.3 & -20.4 & -16.3 & -9.5 & -3.6 & 0.8 \\ & & & & & \\ -5.7 & -9.5 & -4.0 & -0.5 & 0.7 & -0.1 \\ -0.2 & 0.6 & -0.1 & -0.3 & -0.1 & 0.0 \\ -4.4 & -11.5 & -12.3 & -8.7 & -4.2 & 0.9 \\ & & & & & \\ -0.9 & -0.7 & -0.1 & 0.3 & 0.3 & 0.0 \\ -0.7 & -0.1 & 0.5 & 0.6 & 0.5 & -0.1 \\ -0.2 & -0.6 & -0.6 & -0.4 & -0.1 & 0.0 \\ & & & & & \\ 1.0 & -0.5 & -1.6 & -1.6 & -1.2 & -0.4 \\ 0.0 & 0.0 & 0.0 & 0.0 & 0.0 & 0.0 \\ -0.2 & 0.3 & 0.5 & 0.3 & 0.1 & 0.0 \\ -0.8 & 0.2 & 1.1 & 1.3 & 1.1 & 0.4 \\ & & & & & \\ 0.5 & -1.4 & -2.5 & -2.8 & -2.7 & -2.0 \\ 0.5 & 0.7 & 0.3 & 0.0 & 0.0 & 0.0\end{array}$

$\begin{array}{rrrrrr}2.9 & 7.4 & 8.8 & 9.8 & 10.2 & 10.0 \\ 2.7 & 6.7 & 8.0 & 9.1 & 9.7 & 10.1 \\ & & & & & \\ -13.5 & -24.1 & -7.7 & 0.7 & 2.8 & -0.6 \\ -11.7 & -22.5 & -17.5 & -10.6 & -5.0 & 1.5 \\ & & & & & \\ -6.3 & -10.5 & -4.6 & -0.6 & 0.7 & -0.1 \\ -0.1 & 0.3 & 0.0 & -0.2 & -0.1 & 0.0 \\ -5.3 & -12.2 & -12.8 & -9.8 & -5.7 & 1.6 \\ & & & & & \\ -0.9 & -0.6 & -0.1 & 0.2 & 0.3 & 0.0 \\ -0.6 & 0.1 & 0.7 & 0.8 & 0.7 & -0.1 \\ -0.3 & -0.7 & -0.7 & -0.6 & -0.4 & 0.1 \\ & & & & & \\ 1.0 & -0.6 & -1.8 & -1.9 & -1.5 & -0.3 \\ 0.0 & 0.0 & 0.0 & 0.0 & 0.0 & 0.0 \\ -0.4 & 0.3 & 0.5 & 0.4 & 0.2 & -0.1 \\ -0.7 & 0.4 & 1.3 & 1.5 & 1.4 & 0.3 \\ & & & & & \\ 0.6 & -1.7 & -3.3 & -3.7 & -3.8 & -2.2 \\ 0.5 & 0.7 & 0.3 & 0.1 & 0.0 & 0.0\end{array}$

\section{European Union}

GDP level (per cent)

GNP level (per cent)

Human Wealth (\% of GDP)

Financial Wealth (\% of GDP)

of which

Capital Stock (\% of GDP)
Net Government debt (\% of GDP)
Net foreign assets ( $\%$ of GDP)

Current balance ( $\%$ of GDP)

Trade Balance (\% of GDP)

Investment Income Balance (\% of GDP)

Consumption (\% of GDP)

Govt Consumption (\% of GDP)

Investment (\% of GDP)

Net exports (\% of GDP)

$\begin{array}{rrrrrr}3.0 & 7.5 & 8.9 & 9.8 & 10.1 & 10.0 \\ 2.7 & 6.8 & 8.1 & 9.1 & 9.7 & 10.1 \\ -10.6 & -20.5 & -6.4 & 0.7 & 2.2 & -0.3 \\ -11.1 & -21.6 & -18.1 & -11.7 & -5.9 & 1.5 \\ -6.1 & -9.9 & -4.3 & -0.7 & 0.6 & 0.0 \\ -0.2 & 0.7 & -0.1 & -0.4 & -0.1 & 0.0 \\ -4.8 & -12.4 & -13.7 & -10.6 & -6.3 & 1.5 \\ & & & & & \\ -0.9 & -0.7 & -0.1 & 0.2 & 0.3 & 0.0 \\ -0.7 & -0.1 & 0.6 & 0.8 & 0.7 & -0.1 \\ -0.2 & -0.7 & -0.7 & -0.6 & -0.4 & 0.1 \\ & & & & & \\ 1.0 & -0.5 & -1.7 & -1.7 & -1.4 & -0.3 \\ 0.0 & 0.0 & 0.0 & 0.0 & 0.0 & 0.0 \\ -0.2 & 0.3 & 0.5 & 0.3 & 0.1 & 0.0 \\ -0.7 & 0.3 & 1.2 & 1.4 & 1.3 & 0.4 \\ & & & & & \\ 0.2 & -1.3 & -2.3 & -2.7 & -2.7 & -1.8 \\ 0.5 & 0.7 & 0.3 & 0.1 & 0.0 & 0.0\end{array}$

Real effective Exchange rate (per cent)

Real Interest rates (percentage point)
0.0

0.6

.5

0.1

1.6

0.0

0.1

0.3

0.0

0.3

0.0

0.0
0.1
-0.3
1.5

0.0
0.0
1.5

0.0
-0.1
0.1

-0.3
0.0
0.0
0.4

-1.8
0.0 


\section{$\mathrm{ECO} / \mathrm{WKP}(98) 6$}

\section{Table A6. Alternative modelling approaches for assessing the macroeconomic implications of ageing}

\begin{tabular}{|c|c|c|}
\hline Study & Country/Period & General Approach \\
\hline \multicolumn{3}{|c|}{ I - Multi-region: general equilibrium model } \\
\hline Present Study & $\begin{array}{l}\text { US, EU, Japan, and the rest of the world divided into } \\
\text { fast-ageing and slow-ageing countries. } \\
\text { (2000-2100) } \\
\text { Emphasis on effects of ageing on a range of domestic and } \\
\text { international stocks and flows. Various policy reforms } \\
\text { examined. }\end{array}$ & $\begin{array}{l}\text { OECD Minilink model: including production, government, household and external sectors. } \\
\text { Consumption based on Blanchard (1985) and Faruquee, Laxton and Symanski (1997). } \\
\text { Life-cycle effect captured by hump-shaped profile of individual labour income and link between } \\
\text { aggregate propensity to consume, and old-age dependency ratio. Assumes near-perfect capital mobility } \\
\text { across the zones. } \\
\text { Effect of ageing on government expenditures as in Liebfritz et al. (1996) }\end{array}$ \\
\hline $\begin{array}{c}\text { Masson and Tryon } \\
\text { (1990) }\end{array}$ & $\begin{array}{l}\text { US, Japan, Germany and a single group of smaller industrial } \\
\text { countries. } \\
(1995-2025) \\
\text { Emphasis on combined effect of higher dependency ratio and } \\
\text { public spendings. }\end{array}$ & $\begin{array}{l}\text { IMF general equilibrium multi-country model (MULTIMOD). Consumption sector based on } \\
\text { Blanchard (1985). } \\
\text { Aggregate consumption function is estimated (pooled regression) with the dependency ratio added } \\
\text { to the set of determinants to capture life-cycle effects. }\end{array}$ \\
\hline \multicolumn{3}{|c|}{ II - Ramsey optimal growth model } \\
\hline $\begin{array}{l}\text { Cutler, Poterba, } \\
\text { Shiener and } \\
\text { Summers (1990) }\end{array}$ & $\begin{array}{l}\text { US, Japan, EU and non-US OECD } \\
(1990-2050) \\
\text { Emphasis on US savings and current account. }\end{array}$ & $\begin{array}{l}\text { Ramsey model modified to include demographic shifts defined as the ratio of the labour force to total } \\
\text { population. Calibrated. No government sector. } \\
\text { Closed-economy version: US, Japan, EU, non-US OECD and total OECD } \\
\text { Two-country version: US and non-US OECD: Interest rates equalised across countries. No relative } \\
\text { price (exchange rate) changes. }\end{array}$ \\
\hline $\begin{array}{c}\text { Borsch-Suppan } \\
\text { (1996) }\end{array}$ & $\begin{array}{l}\text { OECD as a whole and OECD countries divided in } \\
12 \text { sub-groups. } \\
\text { (1990-2040) } \\
\text { Emphasis on intra-OECD capital flows. }\end{array}$ & $\begin{array}{l}\text { Same as in Cutler et al. (1990). } \\
\text { Closed-economy version: OECD as a whole. } \\
\text { Multi-region version: } 12 \text { intra-OECD regions. Population growth and support ratios are the main } \\
\text { sources of cross-country difference. }\end{array}$ \\
\hline
\end{tabular}


Table A6. (contd.)

\section{III - Standard neo-classical growth model: partial equilibrium}

\begin{tabular}{|c|c|c|}
\hline \multicolumn{3}{|c|}{ III - Standard neo-classical growth model: partial equilibrium } \\
\hline $\begin{array}{l}\text { Bosworth and } \\
\text { Burtless (1997) }\end{array}$ & $\begin{array}{l}\text { United States } \\
(2000-2050) \\
\text { Emphasis on comparison of the effects of changes in savings, } \\
\text { domestically and abroad. }\end{array}$ & $\begin{array}{l}\text { Two-factor Cobb-Douglas function. Calibrated. Disaggregation of private savings ratio into pension, } \\
\text { non-pension and corporate retained earnings. } \\
\text { Open-economy model: exogenous exchange rate. Private and government savings determined } \\
\text { exogenously. }\end{array}$ \\
\hline $\begin{array}{l}\text { Mackellar and } \\
\text { Reisen (1997) } \\
\text { Reisen (1997) }\end{array}$ & $\begin{array}{l}\text { OECD and non-OECD regions. } \\
(1995-2050) \\
\text { Emphasis on impact on real capital returns of increased OECD } \\
\text { investment in non-OECD. }\end{array}$ & $\begin{array}{l}\text { Simple two-region (OECD and non-OECD) static model: production based on two-factor } \\
\text { Cobb-Douglas. Detailed demographic structure. } \\
\text { Life-cycle effect captured by age-specific household saving rates. } \\
\text { Partial equilibrium: exogenous exchange rate: no feedback from rates of returns to consumption. }\end{array}$ \\
\hline $\begin{array}{c}\text { Yoshiro, Oshio } \\
\text { (1997) }\end{array}$ & $\begin{array}{l}\text { Japan } \\
(1995-2050) \\
\text { Emphasis on pension and social reform to ease expected } \\
\text { pressures on public finance. }\end{array}$ & $\begin{array}{l}\text { Single country open-economy: ad hoc specification of households and firms behaviour. Estimated } \\
\text { equations for production, savings, gross investment and interest rates. } \\
\text { Aggregate savings rate is a function of dependency ratio and per capita social security benefits. } \\
\text { Elaborate government sector and labour supply function to fully take into account implications of } \\
\text { ageing on public finance as well as on participation rates and labour force. }\end{array}$ \\
\hline $\begin{array}{l}\text { Leibfritz et al. } \\
\quad \text { (1995) } \\
\text { Roseveare et al. } \\
\quad \text { (1996) }\end{array}$ & $\begin{array}{l}\text { G-7 countries separately. } \\
(1995-2030) \\
\text { Emphasis on impact of ageing on public finance and total } \\
\text { saving under current pension regimes. }\end{array}$ & $\begin{array}{l}\text { Closed-economy, single-country accounting framework. Exogenous and constant real interest rates. } \\
\text { Detailed government sector to take into account country-specific institutional characteristic of } \\
\text { pension regimes. } \\
\text { Future profile of private savings obtained by assuming that saving rate for the elderly and working-age } \\
\text { population remain constant over time. }\end{array}$ \\
\hline $\begin{array}{c}\text { Chand and Jaeger } \\
\text { (1996) }\end{array}$ & $\begin{array}{l}\text { G-7 plus Sweden separately } \\
\text { (1995-2050) } \\
\text { Emphasis on impact of ageing on public finance under current } \\
\text { pension regime and pension reform. }\end{array}$ & $\begin{array}{l}\text { Closed-economy, single-country accounting framework. Output growth based on two-factor } \\
\text { Cobb-Douglas. Exogenous and constant real interest rates. Detailed government sector with } \\
\text { country-specific pension funds characteristics. } \\
\text { Growth rate of employment derived from exogenous assumptions about gender-specific labour force } \\
\text { participation rate and unemployment rates, which are kept constant through the projection. }\end{array}$ \\
\hline
\end{tabular}


Table A6. (contd.)

\begin{tabular}{|c|c|c|}
\hline \multicolumn{3}{|c|}{ IV - Dynamic overlapping generations model: general equilibrium } \\
\hline $\begin{array}{l}\text { Auerbach, } \\
\text { Kotlikoff, } \\
\text { Hagemann and } \\
\text { Nicoletti (1989) }\end{array}$ & $\begin{array}{l}\text { US, Japan, Germany and Sweden. } \\
\text { (1960-2050) } \\
\text { Emphasis on the effect of pension reform: raising retirement } \\
\text { age and lowering benefits. }\end{array}$ & $\begin{array}{l}\text { Includes } 75 \text { overlapping generations: consumer with life-cycle hypothesis: allows for the possibility of } \\
\text { bequest: age of death fixed (at 75) and known with certainty. } \\
\text { Closed-economy version: real interest rates and real wages are market-clearing variables. } \\
\text { Small-open economy version: exogenous real interest rates and wages: no adjustment in exchange } \\
\text { rates in response to changes in external balances. }\end{array}$ \\
\hline $\begin{array}{c}\text { Auerbach and } \\
\text { Kotlikoff (1992) }\end{array}$ & $\begin{array}{l}\text { United States } \\
(1960-2050) \\
\text { Emphasis on effect of ageing and fiscal policy on private and } \\
\text { total saving rates. }\end{array}$ & $\begin{array}{l}\text { Same as Auerbach et al. (1989) } \\
\text { Closed-economy }\end{array}$ \\
\hline $\begin{array}{l}\text { Hviding et al. (1998) } \\
\text { and } \\
\text { Fougère and } \\
\text { Mérette (1998) }\end{array}$ & $\begin{array}{l}\text { US, Japan, France, Italy, United Kingdom, Canada and } \\
\text { Sweden. } \\
\text { (1954-2090) } \\
\text { Emphasis on fiscal consolidation and pension reforms: removal } \\
\text { of public pension, cut in replacement rate, raising retirement } \\
\text { age. }\end{array}$ & $\begin{array}{l}\text { Same as in Auerbach et al. (1989) but including } 15 \text { generations; labour supply is exogenous.. } \\
\text { Closed and small open economy versions as in Auerbachet al. (1989) }\end{array}$ \\
\hline Miles (1997) & $\begin{array}{l}\text { United Kingdom and European Union } \\
(1995-2050) \\
\text { Emphasis on the effect of lower replacement rates. }\end{array}$ & $\begin{array}{l}\text { Same as in Auerbach et al. (1989) but including } 60 \text { generations and labour supply is } \\
\text { exogenous. } \\
\text { Closed-economy version. }\end{array}$ \\
\hline \multicolumn{3}{|c|}{ V - Dynamic overlapping generations model: partial equilibrium } \\
\hline $\begin{array}{l}\text { Ando and Moro } \\
\quad(1995)\end{array}$ & $\begin{array}{l}\text { Japan (Ando and Moro): (1985-2090) } \\
\text { United States (Cordoba): (1985-2090) }\end{array}$ & $\begin{array}{l}\text { Model of household consumption/saving behaviour based on detailed household survey information by } \\
\text { cohort: parameters of consumption function estimated with panel data. }\end{array}$ \\
\hline Cordoba (1996) & $\begin{array}{l}\text { Emphasis on the effect of fertility, household composition and } \\
\text { labour force participation on private savings. }\end{array}$ & $\begin{array}{l}\text { Households are divided in cohorts defined by age, marital status and sex of the head, and number of } \\
\text { children. }\end{array}$ \\
\hline
\end{tabular}


ECO/WKP(98)6

Table A7. Shares of the five regions in total population in 1995 and 2050

percentage

\begin{tabular}{cccccc}
\hline & United States & Japan & European Union & $\begin{array}{c}\text { Other fast-ageing } \\
\text { countries }\end{array}$ & Rest of the world \\
\hline 1995 & 5 & 2 & 7 & 30 & 56 \\
2050 & 4 & 1 & 4 & 21 & 70 \\
\hline
\end{tabular}


ECO/WKP(98)6

Table A8. Estimated reaction functions for public debt

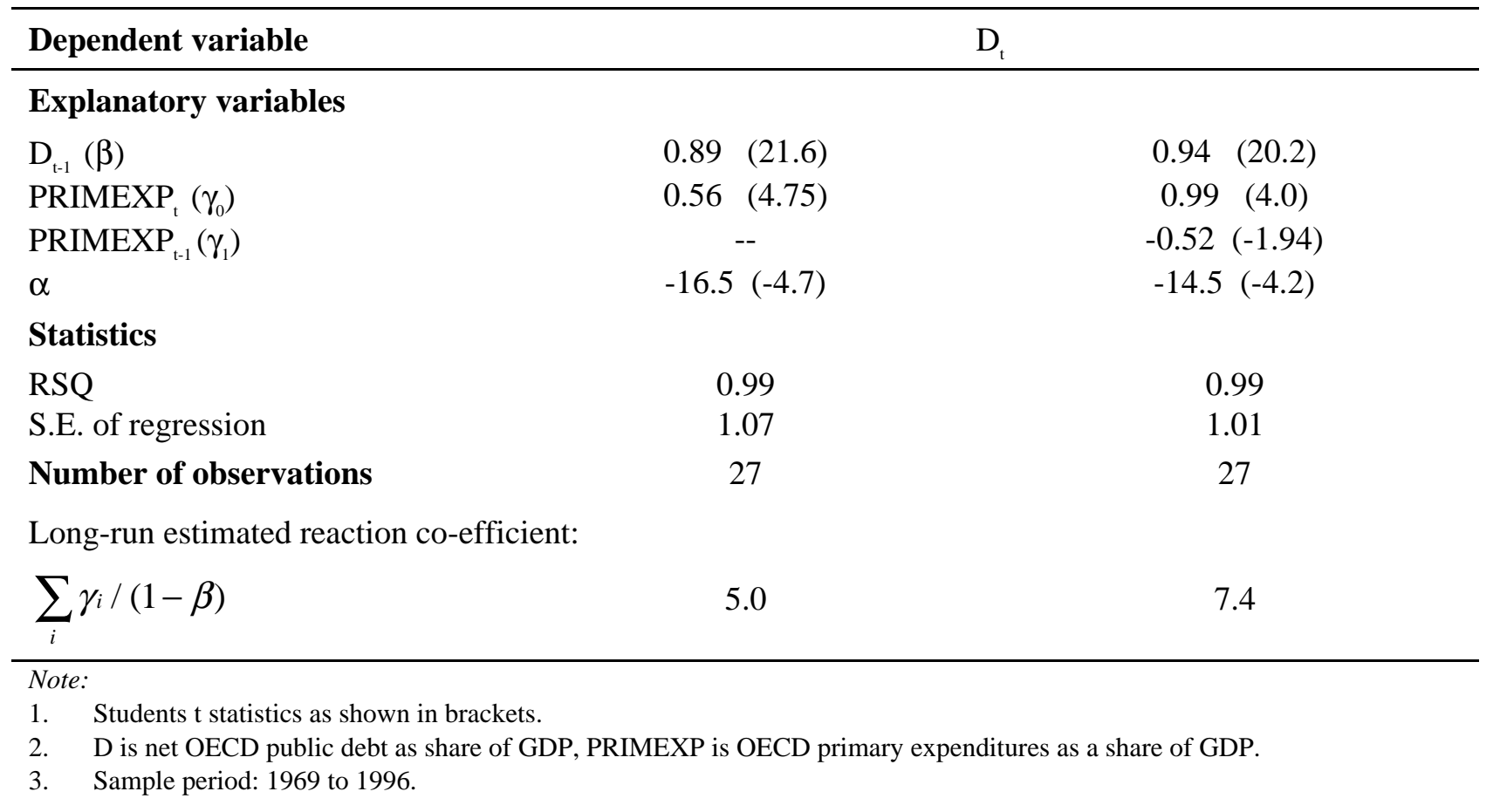


Table A9. OECD-wide debt stabilisation

(Difference from the reference case)

201020202030

\section{United States}

GDP level (per cent)

GNP level (per cent)

Human Wealth (\% of GDP)

Financial Wealth ( $\%$ of GDP)

of which

Capital Stock (\% of GDP)

Net Government debt (\% of GDP)

Net foreign assets (\% of GDP)

Current balance ( $\%$ of GDP)

Trade Balance (\% of GDP)

Investment Income Balance (\% of GDP)

Consumption (\% of GDP)

Govt Consumption (\% of GDP)

Investment (\% of GDP)

Net exports (\% of GDP)

Real effective Exchange rate (per cent)

Real Interest rates (percentage point)

\section{Japan}

GDP level (per cent

GNP level (per cent)

Human Wealth (\% of GDP)

Financial Wealth (\% of GDP)

of which

Capital Stock (\% of GDP)

Net Government debt (\% of GDP)

Net foreign assets ( $\%$ of GDP)

Current balance (\% of GDP)

Trade Balance ( $\%$ of GDP)

Investment Income Balance (\% of GDP)

Consumption (\% of GDP)

Govt Consumption (\% of GDP)

Investment (\% of GDP)

Net exports (\% of GDP)

Real effective Exchange rate (per cent)

Real Interest rates (percentage point)

\section{European Union}

GDP level (per cent)

GNP level (per cent)

Human Wealth (\% of GDP

Financial Wealth (\% of GDP)

of which

Capital Stock (\% of GDP)

Net Government debt (\% of GDP)

Net foreign assets (\% of GDP)

Current balance (\% of GDP)

Trade Balance ( $\%$ of GDP)

Investment Income Balance (\% of GDP)

Consumption (\% of GDP

Govt Consumption (\% of GDP)

Investment (\% of GDP)

Net exports (\% of GDP)

$-0.1$

0.2

17.2

$-0.7$

0.1

0.1
-6.7

-6.7
5.9

0.8

0.8
0.6

0.6
0.3

$-0.9$

$-0.5$

0.8

$-1.3$

0.0

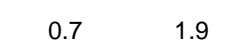

0.1

5.0
1.2

0.6

0.6

0.7
0.8

2.2

$34.8 \quad 56.2$

$0.7 \quad-1.6$

$\begin{array}{rr}4.2 & 9.8 \\ -5.2 & -17.2\end{array}$

$\begin{array}{rr}4.2 & -17.2 \\ -5.2 & 5.9\end{array}$

5.9

$0.3 \quad 0.6$

0.1
0.0

$-0.4$

0.2
0.1
0.1

$$
\begin{aligned}
& 0.3 \\
& 0.1
\end{aligned}
$$

0.3

0.1

$-0.7$

$-0.6$

0.9

0.3

$-0.5$

$-1.3$

1.3

$-0.4$

$-0.6$

$-0.3$

$-0.6$

$\begin{array}{rrr}2.8 & 3.0 & 1.7 \\ 3.3 & 3.6 & 2.7 \\ & & \\ 67.5 & 70.0 & 47.4 \\ -1.7 & -0.6 & 1.0 \\ & & \\ 14.0 & 14.8 & 8.5 \\ -25.1 & -26.4 & -24.5 \\ 9.4 & 11.0 & 17.0 \\ & & \\ 0.5 & 0.5 & 0.6 \\ 0.0 & -0.1 & -0.4 \\ 0.5 & 0.6 & 0.9 \\ & & \\ 0.1 & 0.7 & 1.6 \\ -1.4 & -1.5 & -1.6 \\ 1.2 & 0.9 & 0.4 \\ 0.1 & -0.1 & -0.4 \\ -0.1 & 0.0 & 0.0 \\ -0.9 & -1.0 & -0.6\end{array}$

1.2

2.2

3.0

4.0

6.9

1.6

$46.3-68.7$

$\begin{array}{ll}46.3 & 68.7 \\ -4.4 & -1.4\end{array}$

89.7

109.9

$-5.0$

46.2

$6.2 \quad 11.3$

-26.9
16.3

$-40.0$

15.2
-53.9

$\begin{array}{rr}19.7 & 7.3\end{array}$

\begin{tabular}{rr}
-73.9 & -29.2 \\
\hline &
\end{tabular}

$\begin{array}{ll}1.6 & 1.8\end{array}$

0.8

0.9

1.8
0.3

38.8

49.3

32.5

0.2

$\begin{array}{r}0.2 \\ -2.1 \\ \hline\end{array}$

$\begin{array}{ll}-1.3 & -0.8 \\ -1.1 & -1.1\end{array}$

$-1.1$

1.3

1.1

-1.1
1.4

1.4

$-2.1$

$-1.0$

-1.0
-0.7

$\begin{array}{ll}0.1 & -0.5 \\ 2.2 & 2.8\end{array}$

2.2

4.8

4.8
-1.9

0.2

$-3.1$

6.1

$-0.6$

$-0.9$

0.6
-1.2

$-0.5$

$\begin{array}{rrrrrr}0.2 & 0.7 & 1.7 & 2.9 & 3.6 & 1.7 \\ 0.2 & 0.9 & 2.2 & 4.0 & 5.3 & 2.8 \\ & & & & & \\ 15.4 & 31.4 & 55.7 & 81.3 & 92.5 & 45.8 \\ 2.1 & 4.7 & 1.7 & -1.7 & 3.8 & 13.5 \\ & & & & & \\ 1.2 & 3.8 & 8.7 & 14.5 & 17.7 & 7.9 \\ 0.4 & -2.4 & -16.9 & -36.5 & -43.7 & -10.7 \\ 0.5 & 3.3 & 9.9 & 20.4 & 29.9 & 16.2 \\ & & & & & \\ -0.1 & 0.5 & 1.1 & 1.6 & 1.5 & -0.3 \\ -0.1 & 0.3 & 0.6 & 0.5 & -0.2 & -1.4 \\ 0.0 & 0.2 & 0.5 & 1.1 & 1.7 & 1.1 \\ & & & & & \\ -0.4 & -0.6 & -0.7 & -0.2 & 1.1 & 3.8 \\ 0.0 & -0.5 & -1.5 & -2.4 & -2.7 & -2.3 \\ 0.6 & 0.7 & 1.3 & 1.7 & 1.6 & 0.2 \\ -0.2 & 0.5 & 0.8 & 0.8 & 0.0 & -1.7 \\ 0.5 & -0.5 & -1.2 & -1.5 & -0.8 & 1.1 \\ -0.1 & -0.2 & -0.5 & -0.9 & -1.1 & -0.5\end{array}$


Table A10. Debt stabilisation in Japan only (Difference from the reference case)

\section{United States}

GDP level (per cent)

GNP level (per cent)

$\begin{array}{rrrrrr}0.1 & 0.3 & 0.5 & 0.6 & 0.7 & 0.5 \\ 0.1 & 0.3 & 0.4 & 0.4 & 0.4 & 0.2 \\ & & & & & \\ 5.1 & 8.6 & 10.2 & 11.2 & 11.6 & 6.7 \\ 0.2 & 0.3 & -0.1 & -1.1 & -2.3 & -2.6 \\ & & & & & \\ 0.5 & 1.8 & 2.5 & 3.0 & 3.4 & 2.5 \\ 0.0 & -0.1 & -0.1 & 0.0 & 0.0 & 0.0 \\ -0.3 & -1.4 & -2.5 & -4.0 & -5.7 & -5.1 \\ 0.0 & -0.2 & -0.2 & -0.3 & -0.3 & -0.1 \\ 0.0 & -0.1 & -0.1 & -0.1 & 0.0 & 0.1 \\ 0.0 & -0.1 & -0.1 & -0.2 & -0.3 & -0.3 \\ & & & & & \\ -0.1 & -0.1 & -0.1 & -0.1 & -0.2 & -0.4 \\ 0.0 & 0.0 & 0.0 & 0.0 & 0.0 & 0.0 \\ 0.1 & 0.2 & 0.2 & 0.3 & 0.3 & 0.2 \\ 0.0 & -0.1 & -0.1 & -0.1 & -0.1 & 0.2 \\ & & & & & \\ 0.1 & 0.2 & 0.2 & 0.3 & 0.2 & -0.2 \\ 0.0 & -0.1 & -0.2 & -0.2 & -0.2 & -0.2\end{array}$

Human Wealth (\% of GDP)

Financial Wealth ( $\%$ of GDP)

of which

Capital Stock (\% of GDP)

Net Government debt (\% of GDP)

Net foreign assets (\% of GDP)

Current balance (\% of GDP)

Trade Balance ( $\%$ of GDP)

Investment Income Balance (\% of GDP)

Consumption (\% of GDP)

Govt Consumption (\% of GDP)

Investment (\% of GDP)

Net exports (\% of GDP)

Real effective Exchange rate (per cent)

Real Interest rates (percentage point)

\section{Japan}

GDP level (per cent)

GNP level (per cent)

Human Wealth (\% of GDP)

Financial Wealth (\% of GDP)

of which

Capital Stock (\% of GDP)

Net Government debt (\% of GDP)

Net foreign assets ( $\%$ of GDP)

Current balance ( $\%$ of GDP)

Trade Balance ( $\%$ of GDP)

Investment Income Balance (\% of GDP)

Consumption (\% of GDP)

Govt Consumption (\% of GDP)

Investment (\% of GDP)

Net exports (\% of GDP)

Real effective Exchange rate (per cent)

Real Interest rates (percentage point)
-0.3
0.0

1.1

$-2.2$

$-0.5$

$-6.6$

4.9

0.3

0.1

0.2

$-0.5$

$-0.5$

0.9

0.1

0.1

0.1

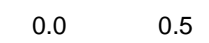

1.0

14.5

$-6.3$

0.2

$-26.9$

20.4

2.5

1.5
1.0

1.0

$-1.0$

$-1.1$$$
-4.2
$$$$
\begin{array}{r}
-4.2 \\
0.0
\end{array}
$$

-2.8
-0.2
0.9

$$
3.7
$$

45.9

\section{European Union}

GDP level (per cent)

GNP level (per cent)

Human Wealth (\% of GDP)

Financial Wealth (\% of GDP)

of which
Capital Stock (\% of GDP)
Net Government debt (\% of GDP)
Net foreign assets (\% of GDP)

Current balance (\% of GDP)

Trade Balance ( $\%$ of GDP)

Investment Income Balance (\% of GDP)

Consumption (\% of GDP)

Govt Consumption (\% of GDP)

Investment (\% of GDP

Net exports (\% of GDP)

Real effective Exchange rate (per cent) Real Interest rates (percentage point) 
Table A11. Debt stabilisation with an increase in the retirement age (Difference from the reference case)

\section{United States}

GDP level (per cent)

GNP level (per cent)

Human Wealth (\% of GDP)

Financial Wealth (\% of GDP)

of which

Capital Stock (\% of GDP)

Net Government debt (\% of GDP)

Net foreign assets (\% of GDP)

Current balance ( $\%$ of GDP)

Trade Balance ( $\%$ of GDP)

Investment Income Balance (\% of GDP)

Consumption (\% of GDP

Govt Consumption (\% of GDP)

Investment (\% of GDP)

Net exports (\% of GDP)

Real effective Exchange rate (per cent)

Real Interest rates (percentage point)

\section{Japan}

GDP level (per cent

GNP level (per cent)

Human Wealth (\% of GDP)

Financial Wealth (\% of GDP)

of which

Capital Stock (\% of GDP)

Net Government debt (\% of GDP)

Net foreign assets ( $\%$ of GDP)

Current balance ( $\%$ of GDP)

Trade Balance ( $\%$ of GDP)

Investment Income Balance (\% of GDP)

Consumption (\% of GDP)

Govt Consumption (\% of GDP)

Investment (\% of GDP)

Net exports (\% of GDP)

Real effective Exchange rate (per cent)

Real Interest rates (percentage point)

3.4
3.3
3.7
-5
-2.8
-2
-0.
-0
-0.2
0.0
-0.4
-0.4
0.8
-0.1
-0.4
0.3

\section{4}

7.0

9.1

9.0

9.8

7.8

3

3.7

26.5

9.3

9.4

10.3

8.7

38.4

$-1.9$

8

-2.8
-2.2
-0.2

$\begin{array}{ll}2.4 & 7.5\end{array}$

$-2.8$

$-4.2$

$\begin{array}{rrr}12.8 & 13.2 & 7.7 \\ -22.6 & -26.0 & -24.8\end{array}$

$\begin{array}{rrrrr}0.6 & -14.1 & -22.6 & -26.0 & -24.8 \\ & 3.7 & 6.9 & 8.6 & 15.3\end{array}$

0.2

$-0.2$

0.3
0.3
0.0

0.4

0.5

$-1.0$

0.2

0.4

$-0.7$

$-0.7$

$-0.7$

$-1.0$

$-0.8$

0.7

0.6

1.1
0.4

$\begin{array}{rr}0.3 & 0.6 \\ -0.1 & -0.2\end{array}$

$0.5 \quad 0.8$

$\begin{array}{ll}-0.3 & 0.4 \\ -0.8 & -0.7\end{array}$

$\begin{array}{ll}-0.8 & -0.7 \\ 1.0 & 0.3\end{array}$

$\begin{array}{ll}1.0 & 0.3 \\ 0.1 & 0.0\end{array}$

0.4

$-1.7$

$-1.0$

$-0.4$

$\begin{array}{ll}-0.3 & -12\end{array}$

$-0.2$

$-0.5$

$-0.8$

$-0.9$

$-0.5$

1.3

8.9

13.6

19.3

18.2

11.7

$-9.7$

17.7

14.5

21.0

20.9

14.0

$-2.6$

50.0

77.0

$97.3 \quad 37.0$

$-23.1 \quad-18.2$

$-15.9$

$-8.6$

8.1

$-1.5$

$-3.2$

$-2.4$

6.8

10.5

19.6

$\begin{array}{lllll}-26.5 & -41.6 & -52.9 & -69.1 & -30.2\end{array}$

2.0

0.6

0.4

16.7

26.4

30.7

0.7

1.9

1.9

40.9

$-0.1$

$-2.2$

2.2

$-0.7$

$-0.1$

0.3

0.6

$-0.9$

0.3

0.8

1.4

3.4

$-1.0$

0.4

$-2.8$

3.6

0.1

$-2.4$

$-5.2$

$-5.7$

$-5.3$

$-1.2$

$-0.5$

\section{European Union}

GDP level (per cent)

GNP level (per cent)

Human Wealth (\% of GDP)

Financial Wealth (\% of GDP)

of which

Capital Stock (\% of GDP)

Net Government debt (\% of GDP)

Net foreign assets (\% of GDP)

Current balance (\% of GDP)

Trade Balance (\% of GDP)

Investment Income Balance (\% of GDP)

Consumption (\% of GDP)

Govt Consumption (\% of GDP)

Investment (\% of GDP)

Net exports (\% of GDP)

$$
0.6
$$

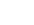

Real effective Exchange rate (per cent)

Real Interest rates (percentage point) 
Table A12. Increase in the retirement age with debt reduction in the US and Europe (Difference from the reference case)

\section{United States}

GDP level (per cent)

GNP level (per cent)

Human Wealth (\% of GDP)

Financial Wealth ( $\%$ of GDP)

of which

Capital Stock (\% of GDP)

Net Government debt (\% of GDP)

Net foreign assets (\% of GDP)

Current balance ( $\%$ of GDP)

Trade Balance ( $\%$ of GDP)

Investment Income Balance (\% of GDP)

Consumption (\% of GDP

Govt Consumption (\% of GDP)

Investment (\% of GDP)

Net exports (\% of GDP)

Real effective Exchange rate (per cent)

Real Interest rates (percentage point)

\section{Japan}

GDP level (per cent

GNP level (per cent)

Human Wealth (\% of GDP)

Financial Wealth (\% of GDP)

of which

Capital Stock (\% of GDP)

Net Government debt (\% of GDP)

Net foreign assets (\% of GDP)

Current balance ( $\%$ of GDP)

Trade Balance ( $\%$ of GDP)

Investment Income Balance (\% of GDP)

Consumption (\% of GDP)

Govt Consumption (\% of GDP)

Investment (\% of GDP)

Net exports (\% of GDP)

Real effective Exchange rate (per cent)

Real Interest rates (percentage point)

\section{European Union}

GDP level (per cent)

GNP level (per cent)

Human Wealth (\% of GDP)

Financial Wealth (\% of GDP)

of which

Capital Stock (\% of GDP)

Net Government debt (\% of GDP)

Net foreign assets (\% of GDP)

Current balance (\% of GDP)

Trade Balance ( $\%$ of GDP)

Investment Income Balance (\% of GDP)

Consumption (\% of GDP)

Govt Consumption (\% of GDP)

Investment $(\%$ of GDP

Net exports (\% of GDP)

Real effective Exchange rate (per cent) Real Interest rates (percentage point)

$\begin{array}{rrrrrr}2.7 & 9.5 & 16.6 & 16.3 & 16.3 & 10.7 \\ 2.7 & 9.5 & 17.1 & 17.8 & 18.5 & 12.6 \\ & & & & & \\ 2.1 & 31.2 & 70.7 & 94.3 & 101.1 & 55.5 \\ -2.4 & -13.7 & -18.9 & -6.7 & -1.8 & 9.2 \\ & & & & & \\ -1.8 & 1.9 & 9.1 & 21.6 & 23.6 & 11.7 \\ 0.2 & -16.3 & -36.1 & -51.5 & -60.4 & -31.8 \\ -0.8 & 0.7 & 8.2 & 23.2 & 35.0 & 29.3 \\ & & & & & \\ -0.1 & 0.5 & 1.3 & 2.4 & 2.1 & 0.4 \\ 0.0 & 0.5 & 0.8 & 1.1 & 0.2 & -1.4 \\ 0.0 & 0.0 & 0.4 & 1.3 & 1.9 & 1.8 \\ & & & & & \\ -0.6 & -2.0 & -2.7 & -2.2 & -1.0 & 2.0 \\ -0.3 & -0.9 & -1.6 & -1.4 & -1.4 & -1.0 \\ 0.9 & 1.9 & 2.6 & 1.5 & 1.5 & 0.4 \\ 0.0 & 1.0 & 1.7 & 2.1 & 0.9 & -1.4 \\ & & & & & \\ -0.2 & -2.3 & -4.3 & -5.1 & -3.4 & 0.1 \\ 0.2 & 0.0 & -0.5 & -1.3 & -1.4 & -0.7\end{array}$


Table A13. Debt stabilisation with an increase in the retirement age implemented with a 10 year lag (Difference from the reference case)

\section{United States}

GDP level (per cent)

GNP level (per cent)

Human Wealth (\% of GDP)

Financial Wealth (\% of GDP)

of which

Capital Stock (\% of GDP)

Net Government debt (\% of GDP)

Net foreign assets (\% of GDP)

Current balance ( $\%$ of GDP)

Trade Balance ( $\%$ of GDP)

Investment Income Balance (\% of GDP)

Consumption (\% of GDP

Govt Consumption (\% of GDP)

Investment (\% of GDP)

Net exports (\% of GDP)

Real effective Exchange rate (per cent)

Real Interest rates (percentage point)

\section{Japan}

GDP level (per cent)

GNP level (per cent)

Human Wealth (\% of GDP)

Financial Wealth (\% of GDP)

of which

Capital Stock (\% of GDP)

Net Government debt (\% of GDP)

Net foreign assets (\% of GDP)

Current balance ( $\%$ of GDP)

Trade Balance ( $\%$ of GDP)

Investment Income Balance (\% of GDP)

Consumption (\% of GDP)

Govt Consumption (\% of GDP)

Investment (\% of GDP)

Net exports (\% of GDP)

Real effective Exchange rate (per cent)

Real Interest rates (percentage point)

\section{European Union}

GDP level (per cent)

GNP level (per cent)

Human Wealth (\% of GDP)

Financial Wealth (\% of GDP)

of which

Capital Stock (\% of GDP)

Net Government debt (\% of GDP)

Net foreign assets (\% of GDP)

Current balance ( $\%$ of GDP)

Trade Balance ( $\%$ of GDP)

Investment Income Balance (\% of GDP)

Consumption (\% of GDP)

Govt Consumption (\% of GDP)

Investment (\% of GDP)

Net exports (\% of GDP)

\section{1 \\ 0.1}

3.4

0.4

0.6

$-0.4$

0.1

0.1

0.1

0.0

$-0.2$

0.0

0.1

$-0.1$

0.0
2030
2100

Real effective Exchange rate (per cent) Real Interest rates (percentage point)

0.1

$-1.6$

\section{$-3.3$}

$-8.2$ 
Table A14. Higher labour force participation rates

(Difference from the reference case)

$20102020 \quad 2030$

2040

2050

2100

\section{United States}

GDP level (per cent)

GNP level (per cent)

$\begin{array}{rrrrrr}1.3 & 3.2 & 5.3 & 7.2 & 7.9 & 8.2 \\ 1.3 & 3.2 & 5.4 & 7.3 & 7.9 & 8.2 \\ -11.9 & -11.7 & -8.2 & -2.9 & -0.3 & 0.3 \\ -2.3 & -3.7 & -3.6 & -2.9 & -1.4 & 0.1 \\ & & & & & \\ -2.4 & -3.5 & -3.3 & -2.2 & -0.7 & 0.1 \\ 0.0 & 0.1 & 0.0 & 0.0 & -0.1 & 0.0 \\ 0.0 & -0.2 & -0.3 & -0.7 & -0.7 & 0.0 \\ 0.0 & 0.0 & -0.1 & -0.1 & 0.0 & 0.0 \\ 0.0 & -0.1 & -0.1 & -0.1 & -0.1 & 0.0 \\ 0.0 & 0.0 & 0.1 & 0.1 & 0.0 & 0.0 \\ & & & & & \\ 0.1 & -0.1 & -0.3 & -0.4 & -0.4 & -0.3 \\ 0.0 & 0.0 & 0.0 & 0.0 & 0.0 & 0.0 \\ 0.0 & 0.1 & 0.3 & 0.3 & 0.1 & 0.0 \\ 0.0 & 0.0 & 0.0 & 0.1 & 0.2 & 0.3 \\ & & & & & \\ 0.0 & 0.1 & 0.4 & 0.3 & 0.2 & -0.2 \\ 0.2 & 0.3 & 0.3 & 0.2 & 0.1 & 0.0\end{array}$

Human Wealth (\% of GDP)

Financial Wealth (\% of GDP)

of which

Capital Stock (\% of GDP)

Net Government debt (\% of GDP)

Net foreign assets (\% of GDP)

Current balance (\% of GDP)

Trade Balance ( $\%$ of GDP)

Investment Income Balance (\% of GDP)

Consumption (\% of GDP)

Govt Consumption (\% of GDP)

Investment (\% of GDP)

Net exports (\% of GDP)

Real effective Exchange rate (per cent)

Real Interest rates (percentage point)

Japan

GDP level (per cent)

GNP level (per cent)

Human Wealth (\% of GDP)

Financial Wealth (\% of GDP)

of which

Capital Stock (\% of GDP)

Net Government debt (\% of GDP)

Net foreign assets ( $\%$ of GDP)

Current balance (\% of GDP)

Trade Balance ( $\%$ of GDP)

Investment Income Balance (\% of GDP)

Consumption (\% of GDP)

Govt Consumption (\% of GDP)

Investment (\% of GDP)

Net exports (\% of GDP)

Real effective Exchange rate (per cent)

\section{European Union}

GDP level (per cent)

GNP level (per cent)

Human Wealth (\% of GDP

Financial Wealth (\% of GDP)

of which

Capital Stock (\% of GDP)

Net Government debt (\% of GDP)

Net foreign assets (\% of GDP)

Current balance (\% of GDP)

Trade Balance (\% of GDP)

Investment Income Balance (\% of GDP)

5.5

Consumption (\% of GDP)

Govt Consumption (\% of GDP)

Investment ( $\%$ of GDP

Net exports (\% of GDP)

Real effective Exchange rate (per cent) Real Interest rates (percentage point) 
Table A15. Higher levels of total factor productivity (Difference from the reference case)

\section{United States}

GDP level (per cent)

GNP level (per cent)

Human Wealth (\% of GDP

Financial Wealth (\% of GDP)

of which

Capital Stock (\% of GDP)

Net Government debt (\% of GDP)

Net foreign assets (\% of GDP)

Current balance ( $\%$ of GDP)

Trade Balance ( $\%$ of GDP)

Investment Income Balance (\% of GDP)

Consumption (\% of GDP

Govt Consumption (\% of GDP)

Investment (\% of GDP)

Net exports (\% of GDP)

Real effective Exchange rate (per cent)

Real Interest rates (percentage point)

\section{Japan}

GDP level (per cent

GNP level (per cent)

Human Wealth (\% of GDP)

Financial Wealth ( $\%$ of GDP)

of which

Capital Stock (\% of GDP)

Net Government debt (\% of GDP)

Net foreign assets ( $\%$ of GDP)

Current balance ( $\%$ of GDP)

Trade Balance ( $\%$ of GDP)

Investment Income Balance (\% of GDP)

Consumption (\% of GDP)

Govt Consumption (\% of GDP)

Investment (\% of GDP)

Net exports (\% of GDP)

Real effective Exchange rate (per cent)

Real Interest rates (percentage point)

$\begin{array}{rrrrrr}0.0 & 0.5 & 1.2 & 1.6 & 1.8 & 1.8 \\ 0.0 & 0.6 & 1.4 & 1.8 & 1.9 & 1.8 \\ -6.0 & -6.9 & -3.9 & -0.6 & 0.2 & 0.5 \\ -0.6 & -1.2 & 0.0 & 1.3 & 1.4 & -0.5 \\ & & & & & \\ -1.6 & -3.4 & -2.5 & -0.8 & -0.1 & 0.1 \\ 0.1 & 0.1 & 0.0 & -0.1 & -0.1 & 0.0 \\ 0.9 & 2.1 & 2.4 & 2.2 & 1.6 & -0.5 \\ & & & & & \\ 0.2 & 0.1 & 0.1 & 0.0 & 0.0 & 0.0 \\ 0.1 & 0.0 & -0.1 & -0.2 & -0.2 & 0.0 \\ 0.0 & 0.1 & 0.2 & 0.2 & 0.1 & 0.0 \\ & & & & & \\ 0.2 & 0.2 & 0.1 & 0.1 & 0.2 & 0.0 \\ 0.0 & 0.0 & 0.0 & 0.0 & 0.0 & 0.0 \\ -0.3 & -0.1 & 0.1 & 0.1 & 0.0 & 0.0 \\ 0.1 & 0.0 & -0.2 & -0.3 & -0.3 & 0.0 \\ & & & & & \\ -0.2 & 0.3 & 0.9 & 1.3 & 1.3 & 0.8 \\ 0.1 & 0.3 & 0.2 & 0.1 & 0.0 & 0.0\end{array}$

3.4

$-6.7$

$-14.1$

$-5.2$

$-0.1$

$-8.7$

$-1.4$

$-1.0$

$-0.4$

1.2

0.0

$$
8.3
$$

$-21.3$

$-27.4$

$-9.6$

0.3

$-18.1$

$-0.9$

0.1

$-1.0$

$-0.7$

0.0

0.1

-3.4
0.7
10.6

9.5

$-7.9$

$-21.3$

$-4.7$

0.0
-16.7

$-16.7$

$-0.1$

0.9

$-1.0$

$-2.1$

-2.1
0.0
0.4

$-5.5$

0.3
11.5

10.7

0.1

$-12.4$

$-1.0$

$-0.1$

$-11.3$

0.2

0.2
1.0
-0.7

$-0.7$

$-2.3$

0.0

0.3

-5.9
0.1
11.9

11.5

2.8

$-5.1$

0.7

$\begin{array}{ll}0.7 & 0.0 \\ -0.1 & 1.7\end{array}$

$0.3 \quad 0.0$

$\begin{array}{ll}0.3 & -0.1 \\ 0.7 & -0.1\end{array}$

$\begin{array}{ll}-0.4 & 0.1\end{array}$

$-1.8$

0.0

0.2

$-5.6$

0.0

\section{8}

8

.5

.0

0.5

0

\section{European Union}

GDP level (per cent)

GNP level (per cent)

Human Wealth (\% of GDP)

Financial Wealth (\% of GDP)

of which
Capital Stock (\% of GDP)
Net Government debt (\% of GDP)
Net foreign assets (\% of GDP)

Current balance (\% of GDP)

Trade Balance (\% of GDP)

Investment Income Balance (\% of GDP)

Consumption (\% of GDP)

Govt Consumption (\% of GDP)

Investment (\% of GDP)

Net exports ( $\%$ of GDP)

Real effective Exchange rate (per cent) 
Table A16. Macroeconomic effects of faster growth in the two mainly non-OECD regions (Difference from the reference case)

\section{United States}

GDP level (per cent)

GNP level (per cent)

$\begin{array}{rrrrrr}-1.6 & -4.0 & -4.5 & -3.4 & -1.5 & -0.2 \\ -1.4 & -2.1 & -0.7 & 1.5 & 2.8 & -0.6 \\ & & & & & \\ -54.2 & -64.6 & -51.1 & -25.9 & -4.9 & -1.5 \\ 0.3 & 12.1 & 34.3 & 53.7 & 56.2 & -9.7 \\ & & & & & \\ -9.3 & -19.6 & -21.1 & -15.7 & -6.6 & -0.8 \\ 0.7 & 0.9 & 0.2 & -0.5 & -0.8 & 0.0 \\ 9.0 & 30.8 & 55.1 & 69.9 & 63.5 & -8.9 \\ & & & & & \\ 1.9 & 3.3 & 3.7 & 2.8 & 0.3 & -0.1 \\ 1.6 & 1.4 & -0.2 & -2.3 & -4.1 & 0.2 \\ 0.3 & 1.9 & 3.9 & 5.1 & 4.4 & -0.4 \\ & & & & & \\ 0.5 & 1.0 & 2.7 & 5.2 & 7.5 & 2.8 \\ 0.0 & 0.0 & 0.0 & 0.0 & 0.0 & 0.0 \\ -2.4 & -2.1 & -1.1 & 0.0 & 0.8 & 0.0 \\ 1.9 & 1.1 & -1.6 & -5.2 & -8.3 & -2.8 \\ & & & & & \\ -1.5 & 0.8 & 5.2 & 10.9 & 15.7 & 11.5 \\ 0.6 & 1.5 & 1.6 & 1.2 & 0.5 & 0.1\end{array}$

Human Wealth (\% of GDP)

Financial Wealth ( $\%$ of GDP)

of which

Capital Stock (\% of GDP)

Net Government debt (\% of GDP)

Net foreign assets (\% of GDP)

Current balance (\% of GDP)

Trade Balance (\% of GDP)

Investment Income Balance (\% of GDP)

Consumption (\% of GDP)

Govt Consumption (\% of GDP)

Investment (\% of GDP)

Net exports (\% of GDP)

Real effective Exchange rate (per cent)

Real Interest rates (percentage point)

\section{Japan}

GDP level (per cent)

GNP level (per cent)

Human Wealth (\% of GDP)

Financial Wealth (\% of GDP)

of which

Capital Stock (\% of GDP)

Net Government debt (\% of GDP)

Net foreign assets ( $\%$ of GDP)

Current balance ( $\%$ of GDP)

Trade Balance ( $\%$ of GDP)

Investment Income Balance (\% of GDP)

Consumption (\% of GDP)

Govt Consumption (\% of GDP)

Investment (\% of GDP)

Net exports (\% of GDP)

Real effective Exchange rate (per cent)

Real Interest rates (percentage point)

\section{European Union}

GDP level (per cent)

GNP level (per cent)

Human Wealth (\% of GDP)

Financial Wealth (\% of GDP)

of which

Capital Stock (\% of GDP)
Net Government debt (\% of GDP)
Net foreign assets (\% of GDP)

Current balance (\% of GDP)

Trade Balance (\% of GDP)

Investment Income Balance (\% of GDP)

Consumption (\% of GDP)

Govt Consumption (\% of GDP)

Investment (\% of GDP)

Net exports (\% of GDP)

Real effective Exchange rate (per cent) 
Table A17. Combined reforms

(Difference from the reference case)

\section{United States}

GDP level (per cent)

GNP level (per cent)

Human Wealth (\% of GDP)

Financial Wealth (\% of GDP)

of which

Capital Stock (\% of GDP)

Net Government debt (\% of GDP)

Net foreign assets (\% of GDP)

Current balance ( $\%$ of GDP)

Trade Balance ( $\%$ of GDP)

Investment Income Balance (\% of GDP)

Consumption (\% of GDP

Govt Consumption (\% of GDP)

Investment (\% of GDP)

Net exports (\% of GDP)

Real effective Exchange rate (per cent)

Real Interest rates (percentage point)

\section{Japan}

GDP level (per cent

GNP level (per cent)

Human Wealth (\% of GDP)

Financial Wealth (\% of GDP)

of which

Capital Stock (\% of GDP)

Net Government debt (\% of GDP)

Net foreign assets ( $\%$ of GDP)

Current balance ( $\%$ of GDP)

Trade Balance ( $\%$ of GDP)

Investment Income Balance (\% of GDP)

Consumption (\% of GDP)

Govt Consumption (\% of GDP)

Investment (\% of GDP)

Net exports (\% of GDP)

Real effective Exchange rate (per cent)

Real Interest rates (percentage point)

\section{European Union}

GDP level (per cent)

GNP level (per cent)

Human Wealth (\% of GDP

Financial Wealth (\% of GDP)

of which

Capital Stock (\% of GDP)
Net Government debt (\% of GDP)
Net foreign assets ( $\%$ of GDP)

Current balance (\% of GDP)

Trade Balance ( $\%$ of GDP)

Investment Income Balance (\% of GDP)

Consumption (\% of GDP)

Govt Consumption (\% of GDP)

Investment (\% of GDP)

Net exports (\% of GDP)

6.1

$-8.9$

$-18.0$

$-7.2$

$-3.6$

$-7.3$

$-1.0$

$-0.7$

$-0.3$

0.2

$-0.2$

0.8

$-0.7$

0.1

0.7
2030

$\begin{array}{rrrrrr}3.3 & 7.9 & 11.5 & 13.5 & 14.6 & 13.6 \\ 3.3 & 8.3 & 12.2 & 14.7 & 15.9 & 15.2 \\ & & & & & \\ -0.9 & 31.2 & 64.9 & 84.9 & 89.2 & 69.6 \\ -5.9 & -9.5 & -10.5 & -7.2 & -4.2 & -4.4 \\ & & & & & \\ -3.8 & 1.1 & 9.9 & 17.8 & 21.0 & 15.4 \\ -3.8 & -16.7 & -33.5 & -43.4 & -46.1 & -44.9 \\ 1.8 & 6.1 & 13.0 & 18.5 & 20.9 & 25.1 \\ & & & & & \\ 0.2 & 0.8 & 1.0 & 0.9 & 0.7 & 0.8 \\ 0.1 & 0.5 & 0.3 & -0.1 & -0.4 & -0.6 \\ 0.0 & 0.3 & 0.7 & 1.0 & 1.1 & 1.4 \\ & & & & & \\ -0.7 & -1.8 & -2.0 & -1.3 & -0.4 & 0.7 \\ -0.2 & -0.4 & -0.7 & -0.8 & -0.9 & -0.9 \\ 0.6 & 1.4 & 2.0 & 2.0 & 1.6 & 0.9 \\ 0.3 & 0.8 & 0.7 & 0.1 & -0.3 & -0.7 \\ & & & & & \\ -0.5 & -0.9 & 0.2 & 1.6 & 2.2 & 2.3 \\ 0.3 & -0.1 & -0.6 & -1.1 & -1.3 & -1.0\end{array}$

Real effective Exchange rate (per cent)

Real Interest rates (percentage point)

$\begin{array}{rrrrrr}7.5 & 19.1 & 33.1 & 40.8 & 43.6 & 41.4 \\ 7.2 & 18.3 & 32.3 & 41.1 & 45.4 & 44.3 \\ -4.7 & 17.5 & 57.2 & 98.7 & 117.0 & 78.1 \\ -14.2 & -35.1 & -43.9 & -31.2 & -12.9 & 17.3 \\ & & & & & \\ -7.3 & -6.1 & 2.3 & 15.7 & 23.5 & 15.0 \\ -0.7 & -16.5 & -36.6 & -52.9 & -61.2 & -31.7 \\ -6.2 & -12.5 & -9.6 & 6.0 & 24.8 & 34.1 \\ & & & & & \\ -1.0 & -0.7 & 0.7 & 2.0 & 2.4 & 0.4 \\ -0.7 & 0.0 & 1.2 & 1.8 & 1.2 & -1.6 \\ -0.3 & -0.7 & -0.6 & 0.3 & 1.3 & 2.1 \\ & & & & & \\ 0.1 & -1.7 & -3.7 & -3.8 & -2.4 & 2.2 \\ -0.6 & -1.3 & -2.2 & -2.7 & -2.8 & -2.7 \\ 1.2 & 2.3 & 3.1 & 2.8 & 2.1 & 0.6 \\ -0.6 & 0.7 & 2.8 & 3.6 & 3.1 & -0.2 \\ & & & & & \\ -0.4 & -3.6 & -8.6 & -11.3 & -11.5 & -7.9 \\ 0.7 & 0.6 & -0.1 & -0.9 & -1.4 & -0.9\end{array}$


Figure A1. Fertility and Life expectancy
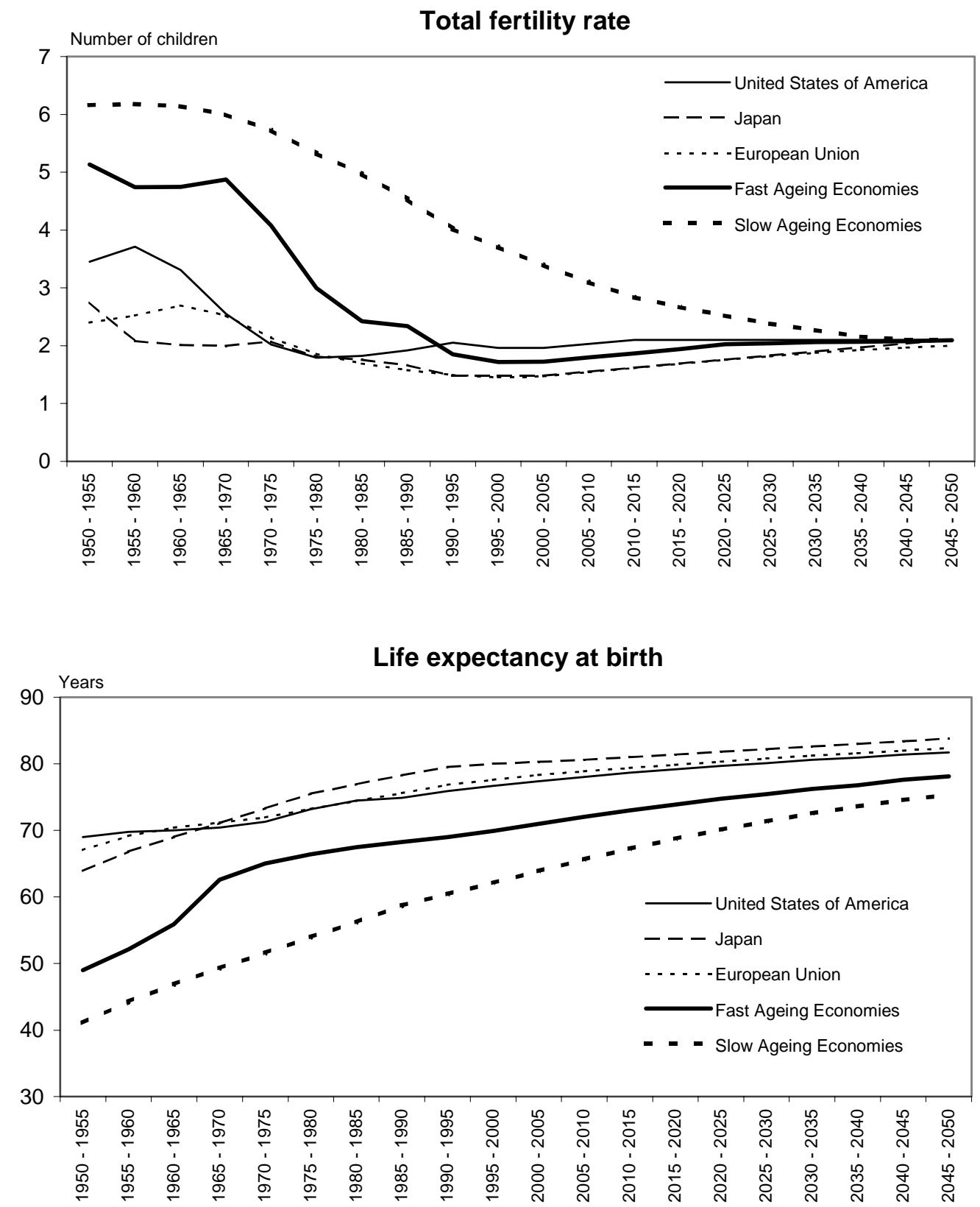
Figure A2. Initial estimates of dependency ratios by region ${ }^{1}$
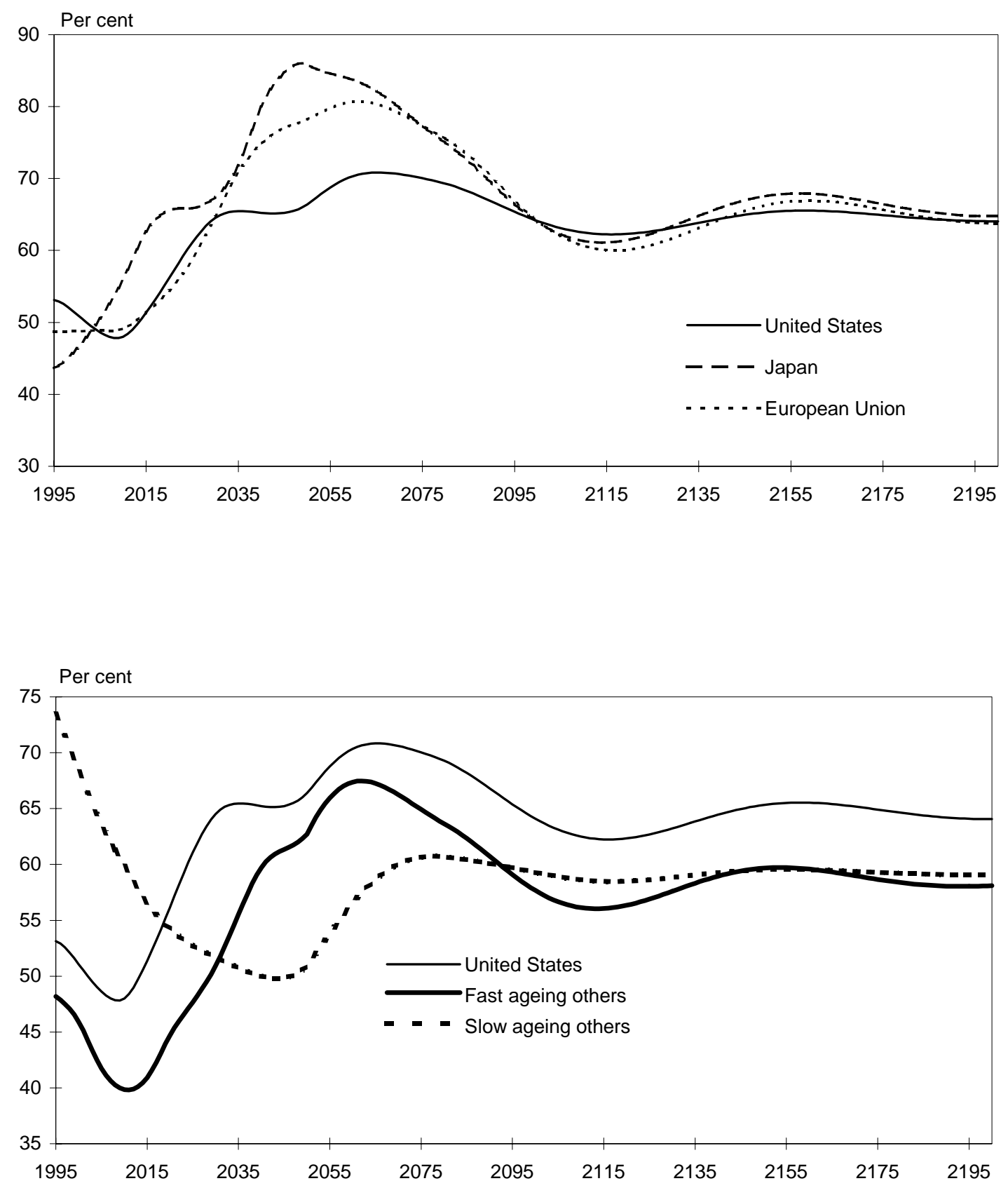

1. Initial estimates based on UN projections extended with the method described in section 2.3 of the Technical Appendix. 
Figure A3. Dependency ratio assumptions in the reference scenario ${ }^{1}$
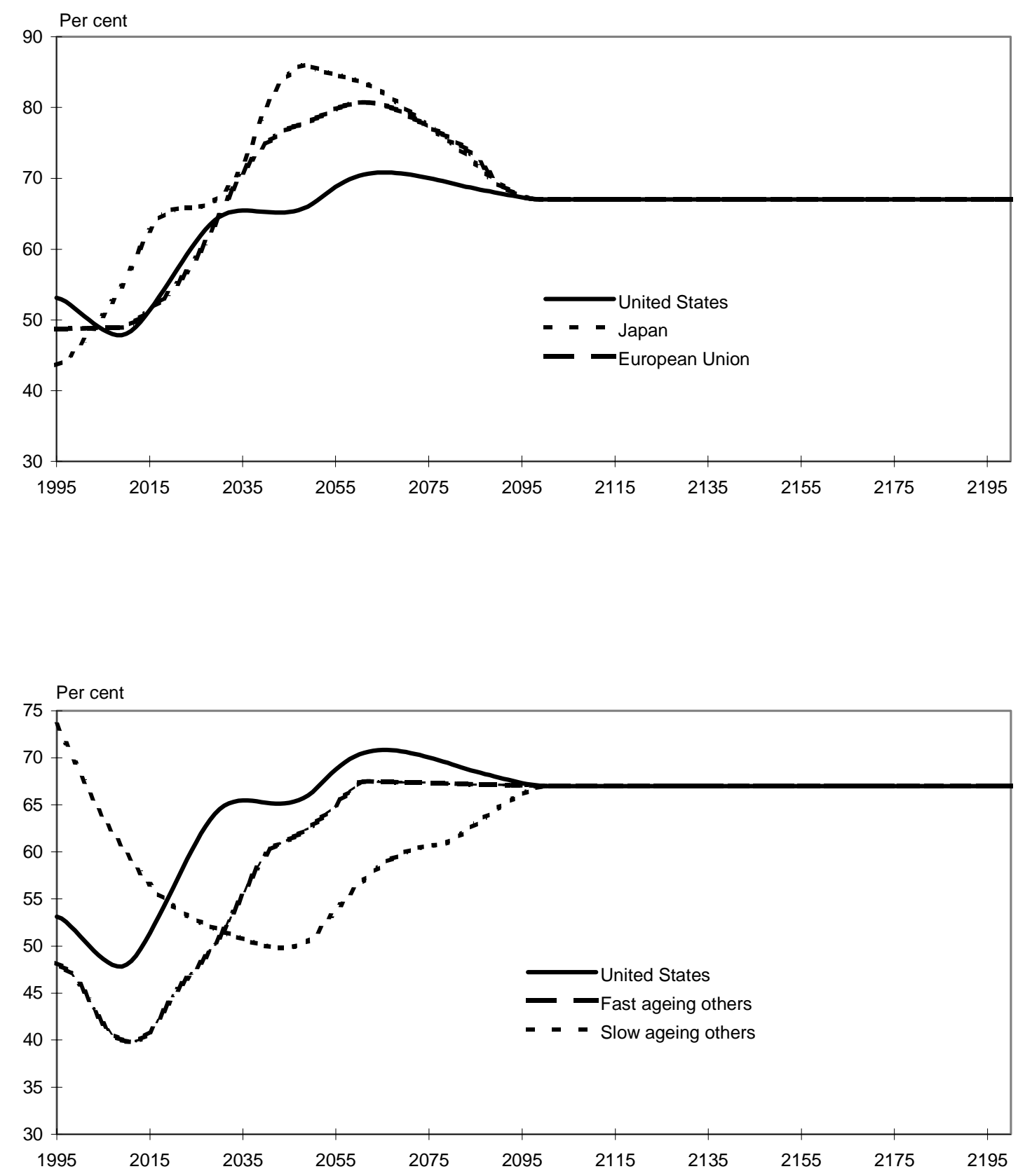

1. Based on the estimates shown in Figure A2, adjusted to consistent convergence paths. 
Figure A4. Assumed shares of the elderly in total population

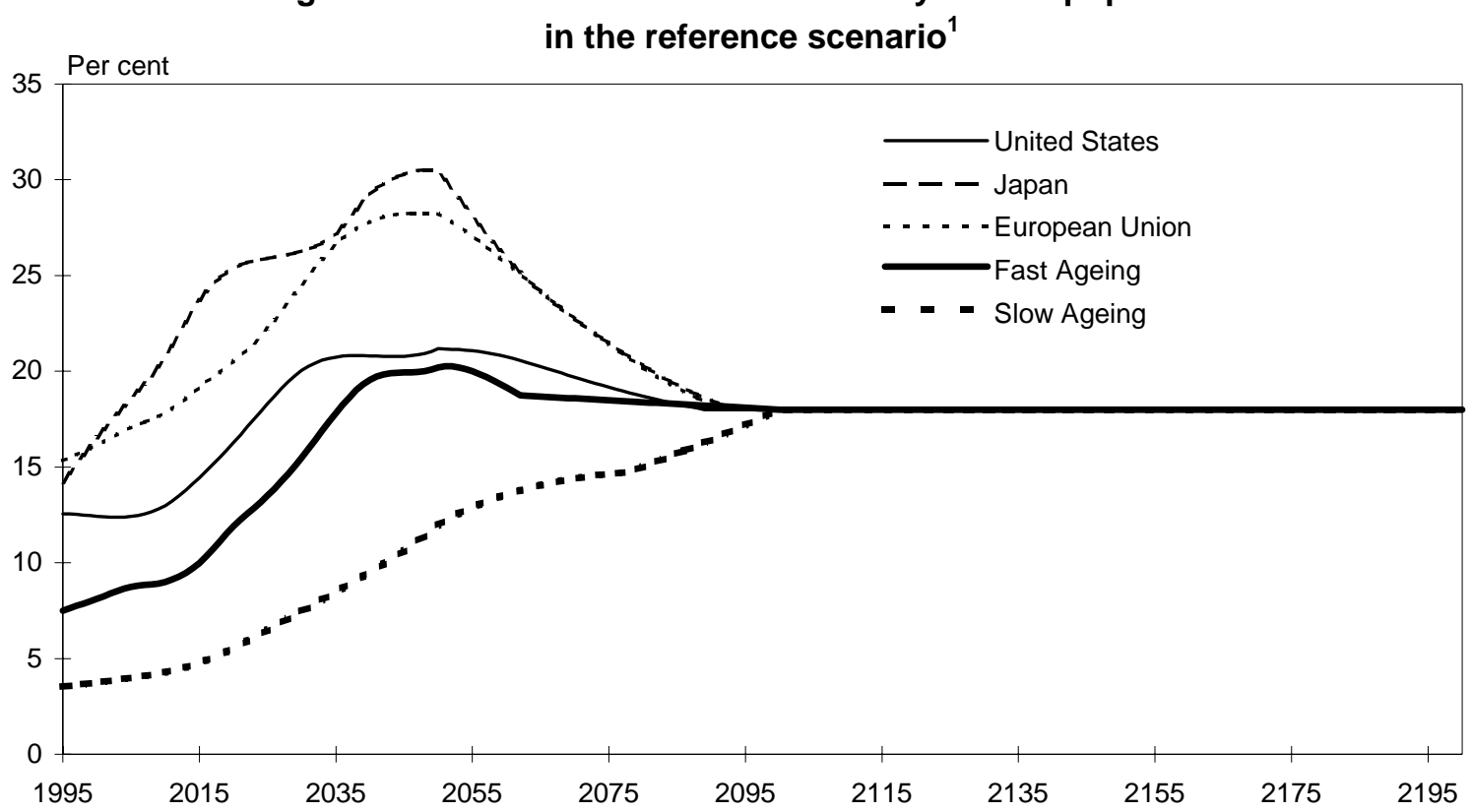

1. Percentage shares of the elderly in total population based on UN projections extended to 2200 
Figure A5. Implicit death rates in the reference scenario

\section{United States}

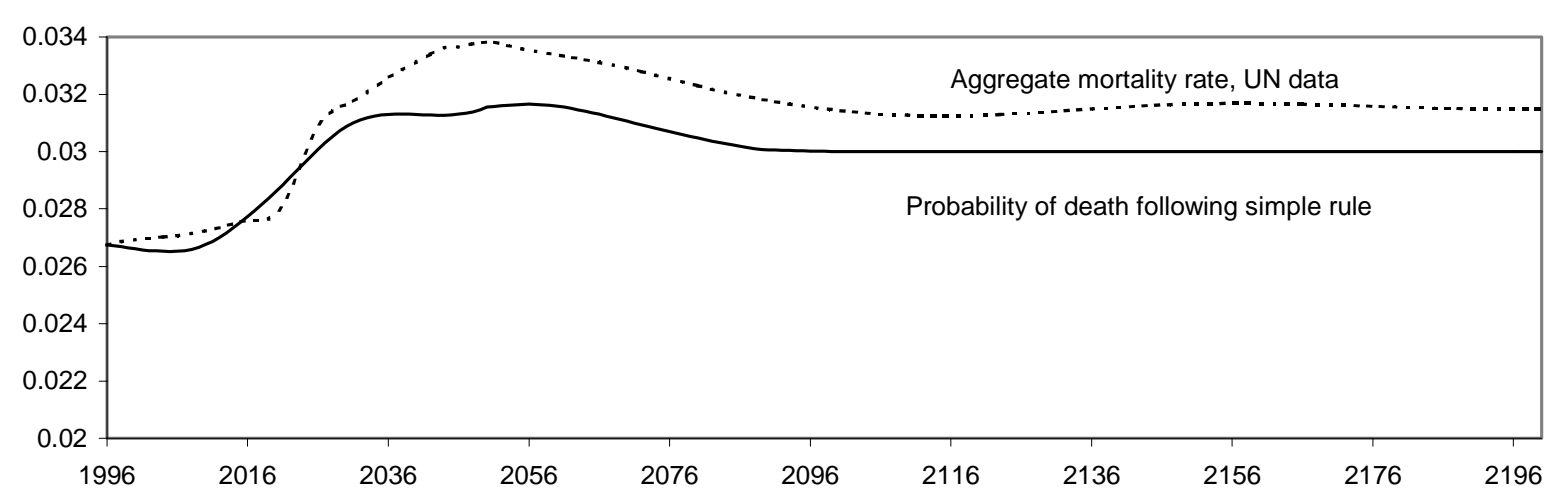

\section{European Union}

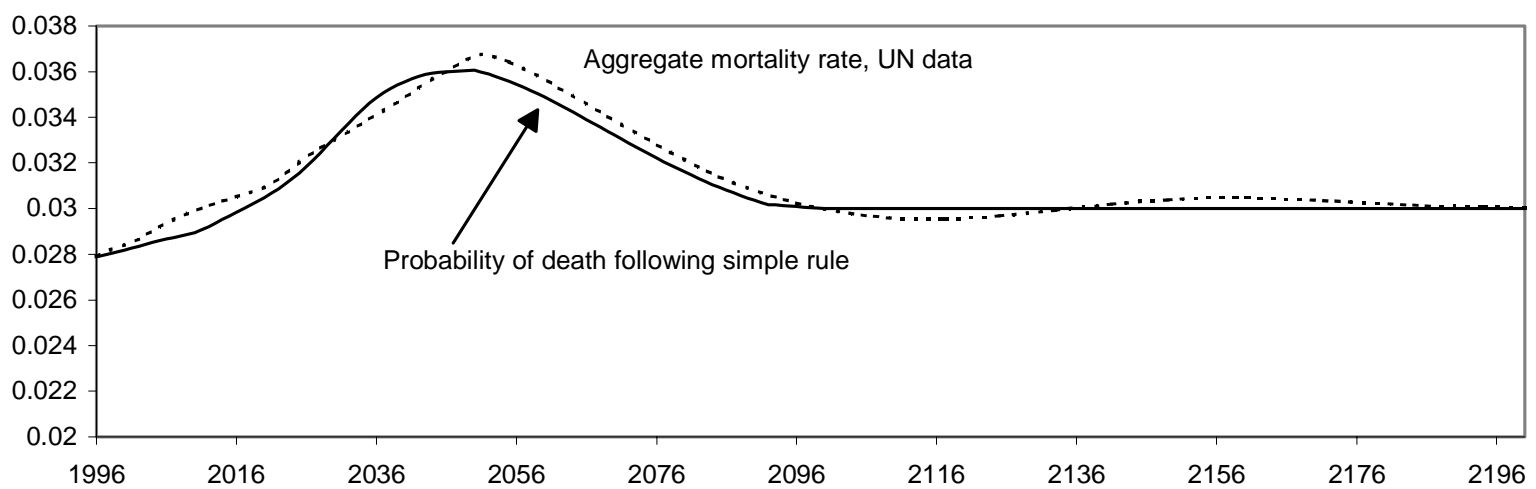

Japan

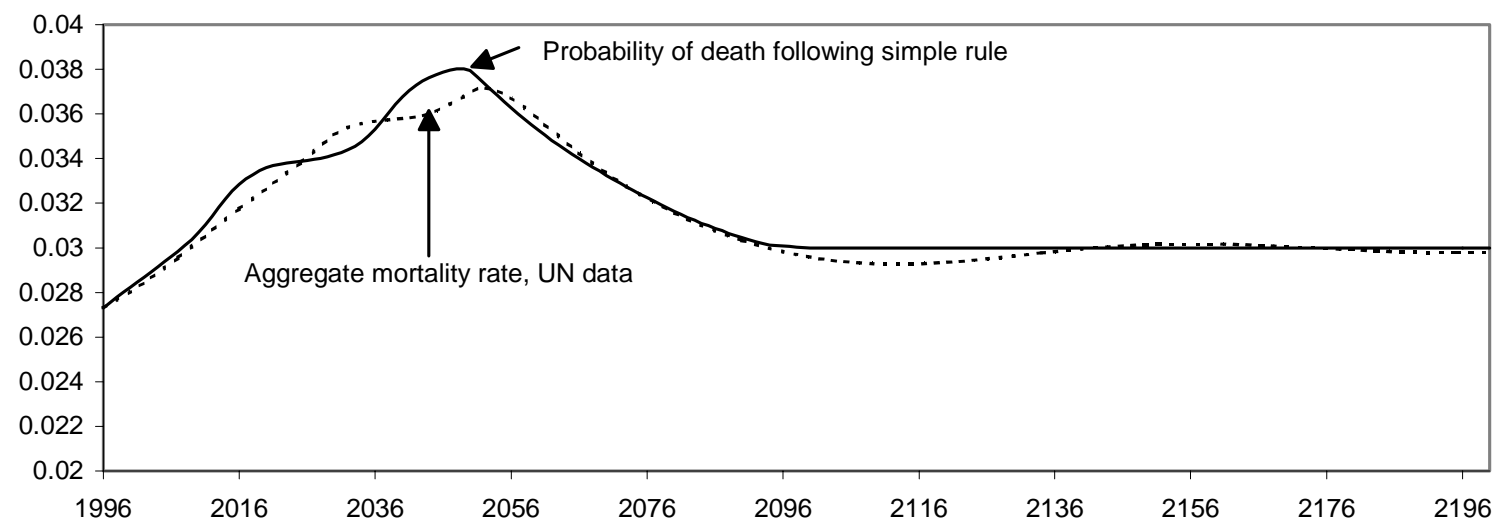


Figure A6. Estimates of ex-ante public savings obtained from later retirement ${ }^{1}$

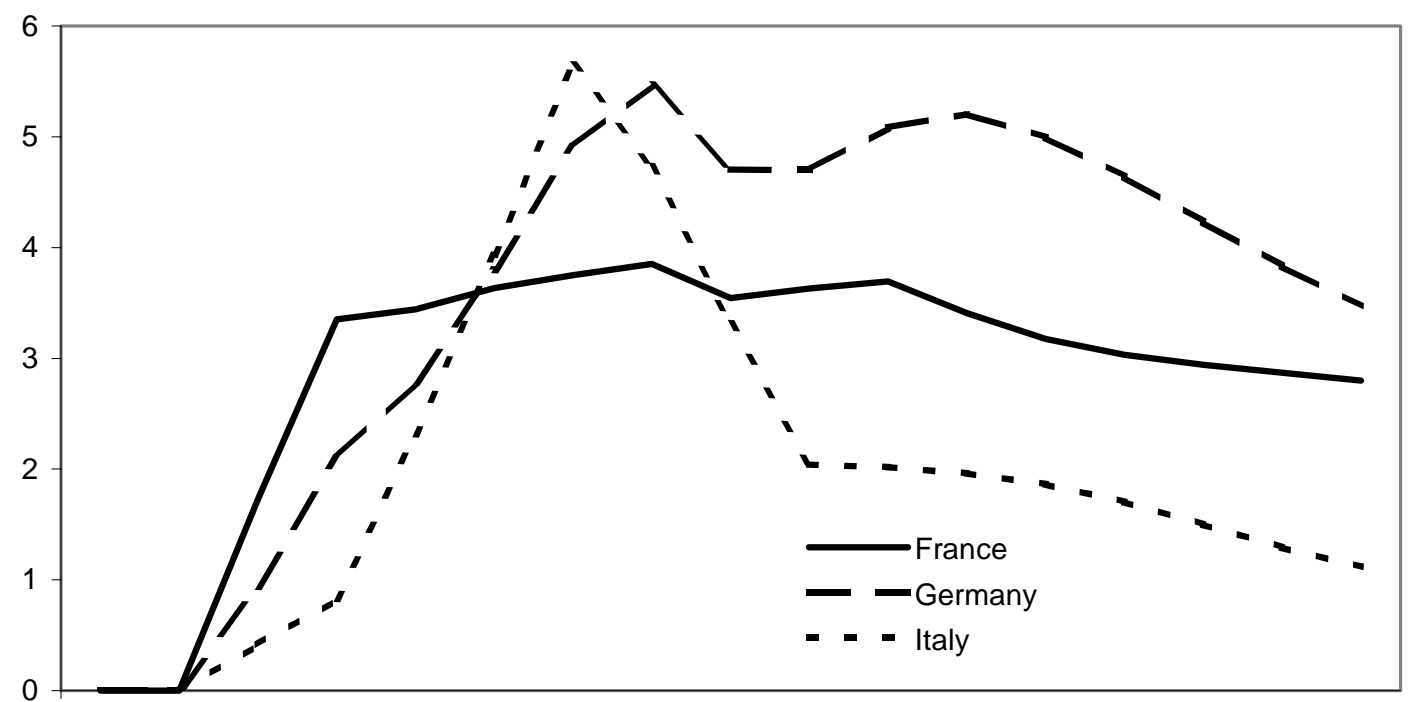

$2000200520102015202020252030 \quad 20352040 \quad 2045 \quad 2050205520602065207020752080$

1. Estimated ex-ante savings in retirement related expenditures and transfers (as a percentage of GDP) associated with later retirement, as described in section 2 of the main paper and section 3 of the Technical Annex. 
ECO/WKP(98)6

\section{ECONOMICS DEPARTMENT \\ WORKING PAPERS}

192. Efficiency and Distribution in Computable Models of Carbon Emission Abatement (March 1998) Joaquim Oliveira Martins and Peter Sturm

191. Monetary Policy when Inflation is Low

(March 1998) Charles Pigott and Hans Christiansen

190. Submission by the OECD to the G8 Growth, Employability and Inclusion Conference (March 1998)

189. Income Distribution and Poverty in Selected OECD Countries

(March 1998) Jean-Marc Burniaux, Thai-Thanh Dang, Douglas Fore, Michael Förster, Marco Mira d'Ercole and Howard Oxley

188. Asset Prices and Monetary Policy

(February 1998) Mike Kennedy, Angel Palerm, Charles Pigott and Flavia Terribile

187. NAIRU: Incomes Policy and Inflation

(January 1998) Silvia Fabiani, Alberto Locarno, Gian Paolo Oneto and Paolo Sestito

186. OECD Submission to the Irish National Minimum Wage Commission

(December 1997)

185. OECD Submission to the UK Low Pay Commission

(December 1997)

184. Concept, Measurement and Policy Implications of the NAIRU - Perspective from Belgium (October 1997) Joost Verlinden

183. Structural unemployment in Denmark (September 1997) Agnete Gersing

182. The United Kingdom NAIRU: Concepts, Measurement and Policy Implications (September 1997) Chris Melliss and A.E. Webb

181. Globalisation and Linkages: Macro-Structural Challenges and Opportunities (August 1997) Pete Richardson

180. Regulation and Performance in the Distribution Sector (August 1997) Dirk Pilat

179. Measurement of Non-tariff Barriers (July 1997) Alan Deardorff and Robert M. Stern

178. The NAIRU-Concept: A Few Remarks

(July 1997) Karl Pichelmann and Andreas Ulrich Schuh

177. Structural Unemployment in Finland (July 1997) Pasi Holm and Elina Somervouri 
176. Taxation and Economic Performance

(June 1997) Willi Leibfritz, John Thornton and Alexandra Bibbee

175. Long-Term Interest Rates in Globalised Markets

(May 1997) Hans Christiansen and Charles Pigott

174. International Implications of European Economic and Monetary Union

(May 1997) Norbert Funke and Mike Kennedy

173. The NAIRU in Japan: Measurement and its implications

(March 1997) Fumihira Nishizaki

172. The Unemployment Problem - A Norwegian Perspective

(February 1997) Steinar Holden

171. The Reliability of Quarterly National Accounts in Seven Major Countries: A User's Perspective (February 1997) Robert York and Paul Atkinson

170. Confidence Indicators and their Relationship to changes in Economic Activity

(November 1996) Teresa Santero and Niels Westerlund.

169. Labour Productivity Levels in OECD Countries. Estimates for Manufacturing and Selected Service Sectors (September 1996) Dirk Pilat

168. Ageing Populations, Pension Systems and Government Budgets: Simulations for 20 OECD Countries (September 1996) Deborah Roseveare, Willi Leibfritz, Douglas Fore and Eckhard Wurzel

167. Modelling the Supply Side of the Seven Major OECD Economies

(September 1996) Dave Turner, Pete Richardson and Sylvie Rauffet

166. Size Distribution of Output and Employment: A Data Set For Manufacturing Industries in Five OECD Countries, 1960s-1990

(August 1996) Bart van Ark and Erik Monnikhof

165. Trade and Competition: Frictions after the Uruguay Round

(July 1996) International Trade and Investment Division

164. Corporate Governance, Competition and Performance

(June 1996) Colin Mayer

163. Fiscal Relations within the European Union

(May 1996) Peter Hoeller, Marie-Odile Louppe and Patrice Vergriete

162. Mark-Up Ratios in Manufacturing Industries

(April 1996) Joaquim Oliveira Martins, Stefano Scarpetta and Dirk Pilat

161. Innovation, Firm Size and Market Structure: Schumpeterian Hypotheses and some new Themes (April 1996) George Symeonidis

160. Valuing the right to Tax Incomes: An Options Pricing Approach (April 1996) Teun Draaisma and Kathryn Gordon

159. Innovation and Competitive Advantage

(October 1995) P.A. Geroski 